\title{
THE BOOK OF LORD SHANG
}

\author{
par \\ J. J.-L. DUYVENDAK \\ (1889-1954)
}

1928

Un document produit en version numérique par Pierre Palpant, collaborateur bénévole

Courriel : ppalpant@uqac.ca

Dans le cadre de la collection : «Les classiques des sciences sociales» dirigée et fondée par Jean-Marie Tremblay, professeur de sociologie au Cégep de Chicoutimi

Site web : http ://www.uqac.ca/Classiques_des_sciences_sociales/

Une collection développée en collaboration avec la Bibliothèque Paul-Émile-Boulet de l'Université du Québec à Chicoutimi

Site web : http ://bibliotheque.uqac.ca/ 
Un document produit en version numérique par Pierre Palpant, collaborateur bénévole, Courriel : ppalpant@uqac.ca

à partir de :

\section{The book of Lord Shang, par J. J.-L. DUYVENDAK (1889-1954)}

Éditions Arthur Probsthain, Londres, 1928, 346 pages. Réimpression par Chinese Materials Center, San Francisco 1974.

Polices de caractères utilisée : Times, 10 et 12 points. Mise en page sur papier format LETTRE (US letter), 8.5' x 11'.

Édition complétée le 30 septembre 2005 à Chicoutimi, Québec. 


\section{T A B L E OF C O N T E N T S}

$\underline{\text { Notes }}$

- $\underline{\text { Preface }}$

\section{- INTRODUCTION}

\section{CHAPTER I : SHANG YANG IN HISTORY}

1. Shang Yang and the rise of Ch'in.

2. The Life of Shang Yang [in the Shih-chi - in the Ch'in-ts'ê]].

3. Historical criticism of the Life.

\section{CHAPTER II : SHANG YANG AS SOCIAL REFORMER}

1. Shang Yang's economics.

2. Shang Yang's system of rewards and punishments.

CHAPTER III : THE BOOK OF LORD SHANG and THE SCHOOL OF LAW

1. The Makers of the School of Law.

2. The original ideas of Shang-tzu.

3. Further ideas of the Book of Lord Shang.

4. Influence of the School of Law.

\section{CHAPTER IV : THE TEXT OF THE BOOK OF LORD SHANG}

1. $\quad$ History of the text.

2. Authenticity of the text.

Appendix I. A lost paragraph.

Appendix II. List of references.

\section{— TRANSLATION OF THE BOOK OF LORD SHANG}

\section{CHAPTER I}

1. The Reform of the Law

2. An Order to Cultivate Waste Lands

3. Agriculture and War

4. The Elimination of Strength

\section{CHAPTER II}

5. Discussion about the People

6. The Calculation of Land

7. Opening and Debarring

\section{CHAPTER III}

8. The Unification of Words

9. Establishing Laws

10. The Method of Warfare

11. The Establishment of Fundamentals 
12. Military Defence

13. Making Orders Strict

14. The Cultivation of the Right Standard

\section{CHAPTER IV}

15. The Encouragement of Immigration

16. Compendium of Penalties [lost]

17. Rewards and Punishments

18. Policies

\section{CHAPTER V}

19. Within the Borders

20. Weakening the People

21. [Lost]

22. External and Internal Affairs

23. Prince and Minister

24. Interdicts and Encouragements

25. Attention to Law

26. The Fixing of Rights and Duties

27. [Lost]

28. [Lost]

29. [Lost] 


\section{TO MY WIFE}

Tibi tua 


\section{P R E F A C E}

p.VIII This book gives a complete translation of the work known in Chinese as Shang-chün-shu, and the title, which I have chosen, is a literal rendering of the Chinese designation of the book (101). The Lord of Shang held high office in the state of Chin between 359 and 338 B.C., and the book which bears his name is regarded as belonging to the School of Law. In order to ascertain how far the connection of his name with the book is justified, it has been necessary to study his life, and for a right understanding of the ideas of the book, its relation to the principles of the School of Law have had to be examined. This has been done in the Introduction. I should, however, point out that this aims neither at giving a complete historical study of the Life of Shang Yang, nor at making a complete systematic study of the principles of the School of Law ; both would have far exceeded the scope of an introduction, where naturally the attention should be centred around the man and the book named after him.

Shang Yang and the Book have long been execrated in China. The opinion of a scholar like Su Tung-p'o (1036-1101) p.IX may be regarded as representing the general point of view. This distinguished author and poet says (102) that the name of Shang Yang

« is in the world like fly-specks; speaking about him befouls the mouth and tongue, writing about him sullies the paper; when his methods are applied in the world, ruin of the state, misery of the people, destruction of the family and loss of one's own life follow one after the other.

This would seem enough to keep anyone from attempting a translation ! In modern times, however, opinion has altered considerably. Chang Ping-lin devotes an article (103) to him and his judgment is, on the whole, favourable. It is true, he says, that Shang Yang used very severe methods, but these were necessary in his days and he was just to all. He was

« like a bamboo-frame which keeps a bow straight, and one could not get him out of his straightness.

He continues, that criticism on his measures in the rough times in which Shang Yang lived, is like wanting to wait for a hungry man till you can give him fine food, and forbidding him to eat coarse food which might keep him alive!

In Liang Ch'i-ch'ao's Collected Works (104) an essay on p.X Shang Yang by Mai Mêng-hua is inserted, which praises him as being a Chinese Lycurgus or Solon. The author tries to exculpate him from the charge that he rejected all morality, and points out that as a statesman and law-giver he did very important work. 
Miura, in his Chung-kuo-lun-li-hsüeh-shih, also discusses Shang Yang; though he praises him as a capable politician, he criticizes him for his too great stress on war and agriculture, his rejection of morality and his severe punishments.

Finally, Dr. Kuo-cheng $\mathrm{Wu}$, while assigning to Shang Yang "a most dazzling place in the galaxy of Chinese political philosophers" because of "the originality in his thought and the practicability of his schemes", yet renders "a decisive verdict against Shang Yang's system" (105).

All these discussions of Shang Yang and his book have, so far, been very uncritical. I have therefore found it necessary to devote a good deal of attention both to historical and to literary criticism; it is hoped that the result of these studies, while divesting Shang Yang perhaps of some of his romantic glamour, will be a contribution towards understanding the origin and development of the School of Law.

Apart from the interest which they have for Sinologues, the ideas of the Chinese Legalists certainly deserve the attention also of Western Jurists. They are concerned with similar problems as have occupied the minds of Western philosophers of law, though these are approached with a different background and are seen from a different angle. History of law p.XI will no doubt profit from a study of a development of ideas of law, which have not been affected by Greek philosophy, Roman conceptions, or Christian ideals. I have, in this book, generally refrained from making comparisons, as isolated comparisons have little value and are often misleading, and besides, not being a Jurist, it would have led too far afield. I have, however, tried to discuss the material in such a way that a Jurist will easily see the salient points.

This is the first translation in any language of the Book of Lord Shang. Some summary of its contents has been given in earlier works, notably by Ivanov in the introduction to his Russian translation of Han Fei-tzû (106), and by Forke in his monumental history of ancient Chinese philosophy (107), which is an invaluable vademecum for the student of Chinese thought. While the present book was in the press, there appeared in English, Dr. Kuo-cheng Wu's work (108), which I have just mentioned, and which also contains a summary of the Book of Lord Shang.

While my translation keeps as closely as possible to the original, and tries to preserve the original character of the style, I have endeavoured not to give a dead translation, which would leave to the reader the task of finding a clue to many a sententious and enigmatic phrase. Translation is re-interpretation of thought, and should never be a mechanical rendering of words, least of all in the case of Chinese. A translation into a Western language acquires therefore more clearness, and preciseness of expression than the original p.XII possesses, as Chinese characters have a far wider connotation than the English words by which they are rendered, and verbs and nouns are not differentiated. The word [], lit. "oneness", for example, in order to be clear, has had variously to be 
translated by 'to unify, to make uniform, to con centrate, unity, uniformity, concentration, singleness of purpose", etc.

The text of the Book of Lord Shang is very corrupt, and presents in many places almost insurmountable difficulties. The very best of contemporary scholars, like Wang Hsien-ch’ien, Wang K'ai -yün, Chang Ping-lin, Yen Fu, K'ang Yu-wei, Liang Ch'i-ch'ao, all are said to complain of the difficulty of the Book of Lord Shang (109). I have therefore been obliged to devote more attention to matters of textual criticism than is usual in other translations from the Chinese, where the text is better established. I have been fortunate enough, through the great kindness of the well-known historian, $\mathrm{Mr}$. Ku Chieh-kang, to obtain the best Chinese edition of the Book, published in 1915 by Wang Shih-jun (110). When, during a visit to Peking in 1926, I mentioned to $\mathrm{Mr}$. Ku my intention of publishing a translation of this book, that scholar drew my attention to this edition, which I had seen nowhere, and even presented me with his own copy of it. I have much pleasure in expressing my sincere gratitude to him.

For my study of the School of Law I have derived much p.XIII benefit from Liang Ch'i-ch'ao's publications on the subject, viz. his Chung-kuo-fa-li-hsüeh fa-ta-shih-lun and his Hsien chïn-cheng-chih-ssu-hsiang-shih. A French translation (111) of that part of the latter book, which deals with the Law School, reached me while the present work was being prepared.

I am indebted to Mr. Yen Fu-ching for his assistance in various matters, especially for his help in preparing the Chinese index $(112)^{1}$.

$$
\text { * }
$$

${ }^{1}$ [css : cet index n'est pas repris dans la présente édition]. 


\section{N T R O D U C T I O N}

\section{CHAPTER I}

\section{Shang Yang in History}

\section{Shang Yang and the rise of Ch'in.}

p.1 The name of Shang Yang is connected with the phenomenal rise of the state of Chin. In little more than a century, that state, from being an insignificant and backward country on the far western borders of China, where, separated as it was, by a belt of highlands, it took little part in the life of Chinese civilization, rose to such a commanding position, that it swallowed up the various feudal states and put an end to the existence of the Chou dynasty, which had been tottering for a long time. The Chin dynasty (113), which was then founded, although it was short-lived, made a deep and lasting mark on Chinese history. Its first Emperor, Shih-huang-ti, was a powerful personality, who made a clean sweep of the institutions of the past. With him the ancient history of China closes and a new era begins.

Historians have marvelled at this success. Ssu-ma Chien writes (114) :

« It would not have succeeded but for the advantage of its position, which was difficult of approach and well defended, and had it not been favoured by its configuration ; it would seem that it was aided by Heaven.

p.2 In the famous essay of the young and brilliant scholar Chia I (115) on the "Mistakes of Ch'in" (116), the reasons for Ch'in's greatness and fall are analysed. It is shown that the methods which served Ch'in to reach its aims were not altered when the whole empire had been unified under its sway; how the reign of Chin Shih-huang-ti was tyrannical and severe and how he thereby estranged all sincere people and surrounded himself with flatterers. Chia I begins the account of Ch'in's rise with the period of Shang Yang, who first introduced the measures, which were calculated to make Ch'in into a powerful country. The whole passage is worth quoting.

«Duke Hsiao of Chin based himself on the strongholds of the Hsiao and Hsien passes (117); he held the territory of the province of Yung (118) ; Prince and Ministers kept a close guard and watched the House of Chou. He cherished the idea of rolling the empire up like a mat, of lifting up the whole world in his arms and of tying up the four seas in a sack; moreover he had the intention of swallowing up the eight wild countries. At this time the Lord of 
Shang (119) assisted him; in the interior he fixed models and measures (120), gave his attention to farming and weaving, and made the necessary preparations for defence and attack; .3 abroad he extended the territory in an uninterrupted way from west to east (121) and fought with the feudal lords. Hereupon the people of Chin, with folded hands (122), obtained the land, beyond the west River.

Another interesting testimony we find in a section of the Hsin-hsü by Liu Hsiang (first century B.C.) which has only been preserved in P'ei Yin's commentary on the Shih-chi (123). It says :

«Duke Hsiao of Chin defended the strongholds of the Hsiao Mountains and the Hsien-ku Pass, in order to extend the territory of Yung-chow (124). In the East he annexed Ho-hsi (125) and in the North he occupied the Shang chün (126). His state became rich and the army strong and he dominated all the feudal lords. The House of Chou came under his control, and from all quarters of the Empire congratulations were addressed to Chin as the leader of the fighting states. Chin thereupon became so strong that in six generations it annexed all the feudal states ; this likewise was the result of the plans ${ }_{p .4}$ laid by the Lord of Shang. Indeed the Lord of Shang worked with his whole person and had only one thought. He was entirely devoted to the public weal and did not think of himself; at home, he caused the people to be active in the work of agriculture and weaving, in order to enrich the state, and abroad, to attach importance to the rewards for fighting, so as to encourage brave soldiers ; his laws and orders were enacted rigorously; in the capital he did not flatter nobles and favourites, and in the province he was impartial with regard to those who were distant, with the result that, when his orders were issued, forbidden actions stopped, when his laws were published, crime ceased. Therefore, although the Shu-ching says (127): "Without deflection, without partiality", and the Ode says (128):

The way of Chou was like a whetstone, And straight as an arrow,

in the Law of Ssu-ma (129), which exhorts brave soldiers, and in Hou-chi (130) of the Chou dynasty, who encourages agriculture, there is nothing to change this conception and this is the way by which the feudal states have been annexed.

Therefore Sun Ch'ing (131) says :

«To conquer for four generations is not luck, but calculation. However, without faith the feudal lords fear but do not love.

Now with regard to the Lords Protector like Duke Huan of Ch'i and Wen of Chin, p.5 Huan did not break the covenant of Ko (132) 
and Wen did not violate the term set at Yüan (133), so that the feudal lords feared their power but also loved and trusted them; they saved tottering states and continued extinct dynasties and thus the four corners of the Empire came within their power. All this was due to the plans laid down by Kuan Chung and Chiu Fan (134).

Now the Lord of Shang repudiated the old favours of Prince Ang (135) and disregarded good faith in his relations with Wei, taking by deceit the masses of the three armies. Therefore the feudal lords feared his power but did not love and trust him. Now supposing Duke Hsiao had met men like Huan of Chi and Wen of Chin, who would have obtained the leadership of the feudal states, who would have set about to unite the princes of the feudal states and who would have driven the armies of the Empire to attack Ch'in, then Ch'in would have been ruined. There being no Huan or Wen in the Empire, ${ }_{\text {p. }}$ Ch'in succeeded in annexing all the feudal states. Wei Yang at first thought that he knew the virtues of a Lord Protector or King (136), but really his actions do not bear comparison (with men like Huan and Wen).

Of old, Shao (137) of the Chou family exercised a virtuous government, and when he had died, the later generations still thought of him. This is the meaning of the Ode "The umbrageous sweet pear-tree" (138); for he had rested under that pear-tree and later generations, remembering his virtue, could not bear to hew it down. How much less would they have harmed his person! When Kuan Chung obtained the three hundred families of the city of the Po family, there was not a word of resentment (139). But now Wei Yang in the interior made a cruel use of the punishments of sword and saw and abroad he was deeply steeped in killing by means of the war-axe. Whosoever used paces more than six feet ${ }_{\mathrm{p} .7}$ long was punished (140), and whosoever threw ashes on the Street incurred bodily punishment. One day he sentenced criminals, more than seven hundred men, on the brink of the Wei river, so that the water of the Wei became entirely red (141), and the Sound of crying and weeping stirred up heaven and earth; the discontent and hatred which he heaped up was like a mountain, and when he fled, he could bide nowhere, was received nowhere, and he died and was torn to pieces by chariots, and his whole family was exterminated without even leaving their name.

This was indeed far from the way of a helper of a Lord Protector or a King ! However, that King Hui killed him was also wrong. He could have assisted him and been useful. Suppose Wei Yang had practised a magnanimous and equitable law, had added to that a measure of grace, and in his announcements had kept faith, he might perhaps have become an assistant of a Lord Protector. 


\section{The Life of Shang Yang.}

From the foregoing it will be clear that the Lord of Shang, apart from his supposed connection with the Book, is a person of considerable interest in history. I propose therefore to ${ }_{\text {p. }}$ give his biography in full, first as it is given in the Shih-chi (142), and then in the short form of the Chan-kuo-ts'ê (143). Thereafter we shall discuss the authenticity of these stories.

\section{A. The Biography of the Lord of Shang (144) in the Shih-chi}

The Lord of Shang was one of the descendants, by a concubine, of the family of Wei. His name was Yang, and his family name was Kiung-sun (145). His ancestors had, originally, the surname of Chi. In his youth, he was fond of the study of criminal law; he served Kung-shu Tso (146), the ${ }_{\text {p. } 9}$ Minister of Wei, and became chung-shu-tzu (147). Kung-shu Tso knew that he was capable, but before presenting him at court, it so happened that (Kung-shu) Tso fell ill. King Hui (148) of Wei went personally to inquire after his illness and said :

- Your illness is too serious not to speak about it : what provision should be made in future for the altar of the soil and grain (149)?

Kung-shu Tso said :

- My chung-shu-tzu, Kung-sun Yang, though young still in years, has talent. May the King be pleased to listen to him in all state affairs.

The King was silent. When the King was on the point of leaving, Tso bade everyone go out, and laid :

- If Your Majesty will not listen to Yang, nor employ him, then You should put him to death and not allow him to leave the country.

The King assented and departed. Kung-shu Tso called Yang, and taking leave of him said :

- To-day, the King inquired of me who could be appointed councillor, and I mentioned you. From the King's appearance. I believe he did not agree with my suggestion. I then placed the interest of the King before that of the subject, and therefore said to the King, that if he were not going to employ Yang he should kill him, and the King agreed to my suggestion. You had better leave as soon as possible or else you will be ${ }_{\text {p.10 }}$ arrested.

Yang replied : 
- If the King does not act on your words to appoint me, how should he act on your words to kill me ?

In the end he did not leave.

As soon as King Hui had left, he said to his entourage :

- It is regrettable that Kung-shu is so ill! He desires me to employ Kung-sun Yang as state councillor - is this not absurd (150)?

As soon as Kung-shu had died, Kung-sun Yang heard that Duke Hsiao of Ch'in had issued an order, inviting the capable men throughout the country, in order to restore the heritage of Duke $\mathrm{Mu}$, and to recover the occupied territory in the east (151). He, thereupon, went westward to ${ }_{\text {p.11 }}$ Chin and through Ching Chien (152), a favourite of Duke Hsiao, obtained an interview with Duke Hsiao. When Duke Hsiao received Wei Yang, they talked for a long time about affairs, but Duke Hsiao repeatedly fell asleep and did not listen. At the conclusion of the interview, he was angry with Ching Chien, saying :

- This guest of yours is a good-for-nothing, how should he deserve to be employed ?

Ching Chien reproved Wei Yang, who replied :

- I talked to the Duke about the Way of the Emperors, but his interest was not awakened.

After five days he (Ching Chien) again requested that Yang be given an audience. At this second interview between Yang and Duke Hsiao, although, there was an improvement, yet he did not strike the Princes attention. When it was over, Duke Hsiao again reproved Ching Chien, who in turn reproved Yang. The latter said :

- I talked to the Duke about the Way of the Kings, but I did not get my argument home.

He (Ching Chien) requested that Yang be again given an audience, and when Yang was received by Duke Hsiao, the latter liked him, without, however, employing him. At the conclusion, when he had gone, Duke Hsiao said to Ching Chien :

- Your guest is an interesting man to talk to !

Yang said :

- I spoke to the Duke of the Way of the Lords Protector and he was inclined to make use of it. If indeed he will have another interview with me, then I shall know.

When Wei Yang had another interview with Duke Hsiao, the Duke, in talking with him, did not himself notice that his (Wei Yang's) knees had advanced on to his mat. He talked with him several days without being tired of it. Ching Chien said : 


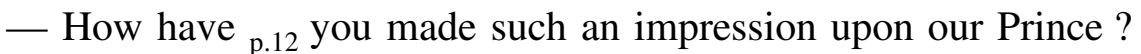
He is extraordinarily pleased with you.

Yang replied :

- When I talked to the Prince of the Way of the Emperors and Kings and made comparisons between the Three Dynasties, the Prince said :

« This takes a long time and is a distant ideal. I cannot wait! Besides, capable princes have always made their fame shine through the world, during their own lifetime, how can one anxiously wait several thousand years, in order to become an emperor or king ?»

«When, therefore, I spoke to the Prince of the methods of making a state powerful, he was greatly delighted with them. However, as far as virtue is concerned, it is difficult to compare them with those used by the Yin and Chou dynasties.

As soon as Duke Hsiao employed Wei Yang, the latter desired to alter the laws, but the former feared that the Empire might find fault with him (153), whereupon Wei Yang said (154):

- He, who hesitates in action, obtains no fame; he who hesitates in affairs, gains no merit. Moreover, he who conducts himself as an outstanding man, is, as a matter of course, disapproved of by the world, and he, who has thoughts of independent knowledge, is certainly despised by the p.13 people. The stupid do not even understand an affair, when it has been completed, but the vise see it before it has sprouted. One cannot let the people share in the thoughts about the beginning of an affair, but they should be allowed to share in the rejoicings over its completion. He, who is concerned about the highest virtue is not in harmony with popular ideas; he, who accomplishes a great work, does not take counsel with the multitude. Therefore, a sage, if he is able thereby to strengthen the state, does not model himself on antiquity, nor, if he is able thereby to benefit the people, does he adhere to established rites.

Duke Hsiao expressed his approval, but Kan-Lung said :

- Not so. A sage teaches without changing the people, and a wise man obtains good government, without altering the laws. If one teaches in accordance with the spirit of the people, success will be achieved without effort; if one governs holding on to the law, officials will be well versed in it and the people will live quietly by it.

Wei Yang replied : 
- What Lung holds is the point of view of the man-in-the-street. Ordinary people abide by the old customs and scholars are immersed in the study of what is reported (from antiquity). These two kinds of people are all right for filling offices and for maintaining the law; but they are not the kind, who can take part in a discussion, which goes beyond the law. The Three Dynasties have attained supremacy by different rites, and the five Lords Protector have attained their protectorships by different laws. A wise man creates laws, but a foolish man is controlled by them ; a man of talent reforms rites, but a worthless man is enslaved by them.

Tu Chih said :

- Unless the advantage be a hundredfold, one should not reform the law; unless the benefit be tenfold, one should not alter an instrument. In taking antiquity as one's example, one makes no mistakes, and in following established rites, one commits no offence.

Wei Yang replied :

- There is more than one way to govern the world, and there is no necessity to imitate antiquity, in order to take appropriate measures for the state. Therefore, T'ang and $\mathrm{Wu}$ succeeded in attaining supremacy without following antiquity, and the Hsia and Yin dynasties perished, without rites having been altered. Those, who acted counter to antiquity, should not be condemned, nor should those, who followed established rites, merit much praise.

Duke Hsiao said :

— Excellent !

He made Wei Yang Tso-shu-chang (155). Finally he fixed the mandate by which the laws were altered. He ordered the people to be organized into groups of fives and tens mutually to control one another and to share one another's punishments (156). Whoever did not denounce a culprit would be cut in two ; whoever denounced a culprit would receive the same reward as he, who decapitated an enemy; whoever concealed a culprit would receive the ${ }_{\text {p.15 }}$ same punishment as he, who surrendered to an enemy. People, who had two males or more (in the family), without dividing the household, had to pay double taxes (157). Those, who had military merit, all received titles from the ruler (158), according to a hierarchic ladder. Those, who had private quarrels, were punished according to the severity of their offence. Great and small had to occupy themselves, with united force, with the fundamental occupations of tilling and weaving, and those who produced a large quantity of grain or silk, were exempted from forced labour. Those, who occupied themselves with secondary sources of profit, and those who were poor through laziness, were taken on as slaves. Those of the princely family, who had no military merit, 
could not be regarded as belonging to the princely clan. He made clear the distinctions between high and low, and between the various ranks and degrees, each according to its place in the hierarchy. He apportioned fields, houses, servants, concubines, and clothes, all differently, according to the families. Those, who had merit, were distinguished by honours ; while those who had no merit, though they might be rich, had no glory whatever.

When the mandate was already drawn up, but still unpublished, fearing that the people would not believe it, he placed a pole of 30 feet near the south gate of the capital, and having summoned the people, said that he would give p.16 ten ounces of gold to anyone, who could remove it to the north gate. The people thought it strange, but there was no one who dared move it. Thereupon, he said that he would give fifty ounces of gold to anyone who would remove it. There was one man, who removed it, and forthwith he gave him the fifty ounces of gold, to make it clear that he deceived no one.

Finally the mandates were published. When they had been enforced upon the people for the term of a year, the people of Chin, who came to the capital and at first said that the laws were not appropriate, could be counted by the thousand. Then, the Crown Prince infringed the law. Wei Yang said :

- It is owing to the infringements by the highly placed, that the law is not carried out. We shall apply the law to the Crown Prince ; as, however, he is Your Highness's heir, we cannot subject him to capital punishment. Let his tutor, Prince Chien, be punished and his teacher, Kung-sun Chia (159), be branded.

The following day, the people of Ch'in all hastened into (the path of) the law. When it had been in force for ten years, the people of Chin greatly rejoiced: things dropped on the road were not picked up $(160)$; in the mountains there were no robbers ; families were self-supporting, and people had plenty; they were brave in public warfare and timid in private quarrels, and great ${ }_{\text {p.17 }}$ order prevailed throughout the countryside and in the towns. From among those of the people of Chin, who had at first said that the mandates were inappropriate, some came to say that the mandates were appropriate. Wei Yang said :

- These are all disorderly people ; they should be banished to the frontiers.

Thereupon, none of the people dared to discuss the mandates.

Then was Yang appointed Ta-liang tsao (161), and at the head of an army he laid siege to An-i in Wei, and conquered it (162). After a lapse of three years, he built pillars for the issuing of mandates and constructed a palace at Hsien-yang (163). Ch'in moved its capit al from Yung (164) thither, and an order was issued ${ }_{\mathrm{p} .18}$ forbidding fathers and sons, elder and younger brothers from living together in the same houses $(\underline{165})$; the small cities, villages and towns were to be combined into districts, hsien (166), over which he placed officials called prefects, ling, and assistants, ch'eng, altogether thirty-one districts. In 
order to obtain arable land he opened up the longitudinal and horizontal paths (167) and the border country, and the $f u$ and shui taxes were p.19 equalized (168); he standardized weights, scales, and measures of quantity and length. After the orders had been in force for four years, Prince Chien (169) again infringed the law, and his nose was sliced off as punishment. After five years the people of Chin were rich and strong, and the Son of Heaven sent a present of sacrificial meat to Duke Hsiao, and all the feudal lords congratulated him (170). In the following year, Ch'i (171) beat the army of Wei at Ma-ling and captured their p.20 crown prince, Shen, and killed their general, P'ang Chüan. In the following year, Wei Yang counselled Duke Hsiao as follows :

- The relations between Chin and Wei are like a man with a disease in his stomach and heart (172). If Wei does not annex Chin, Ch'in will annex Wei. For what is the situ ation ? Wei occupies the country west of the mountain passes and has its capital in An-I (173); it has the Yellow River as frontier in common with Ch'in, but it alone usurps all the advantages of the country east of the mountains. If it is successful, then it will come westward to invade Ch'in, but if it suffers reverses, it will still keep its territory in the east. Now considering, on the one hand, the ability and wisdom of Your Highness, and the prosperous state of the country, and on the other hand, the fact that Wei, in the past year, has suffered severe defeats from Ch'i, and that all the feudal lords have defected from it, we should avail ourselves of this time to attack Wei. If Wei is unable to withstand Chin, it will cert ainly move its capital eastward, and if it does so, Ch'in will be able to rely on the natural strength of the river and mountains, so that in an easterly direction, we shall p.21 be able to control the feudal lords (174). This is an undertaking worthy of an ancient emperor or king !

Duke Hsiao consented and sent Wei Yang, at the head of an army, to attack Wei, while Wei sent Prince Ang at the head of its army to engage him in battle. When the armies were opposite each other, Wei Yang sent a letter to the general of Wei, Prince Ang, saying :

- Originally, I had friendly relations with you, and now we are the generals of two different countries; it is unbearable that we should fight each other, and so I suggest that we have a personal interview, make an alliance with music and drinking, and desist from war, so that Chin and Wei may have peace.

Prince Ang agreed to the proposal ; they met and made an alliance, and when all was over, sat drinking, when suddenly armed soldiers, hidden by Wei Yang, sprang forward and captured Price Ang. Following up this advantage, they attacked his army and completely destroyed it and then returned to Ch'in (175). 
p.22 King Hui of Wei, his army having been repeatedly beaten by Ch'i and Ch'in, being depleted of resources within the state and daily becoming weaker, was afraid, and sent a messenger to cut off the territory, west of the river, and to cede it to Chin, so as to make peace. Wei thereupon left An-i and removed its capital to Ta-liang (176). King Hui of Liang ( =Wei) said :

- I regret that I did not follow the advice of Kung-shu Tso (177).

p.23 When Wei Yang had defeated Wei, on his return to Ch'in, he was awarded fifteen cities in Shang (178), as fief, and was called the Lord of Shang. When Lord Shang had been Chancellor of Ch'in for ten years, the majority of the members of the princely family and of the nobility bore him a grudge. Chao Liang (179) went to see Lord Shang, who said :

- I have had the privilege of having been introduced to you by Meng Lan-kao (180). May I now ask to have your intercourse (181)?

Chao Liang replied :

- I dare not hope for this. K'ung Ch’iu has said : «Where able men are promoted, a virtuous ruler comes to the front, but where men of no merit are assembled, a king of the whole empire will pass into the background (182). » I am a man of no merit and, therefore, I dare not receive your commands. I have heard it said that to occupy a position for which one is not qualified, is called "being covetous of position", and to have a reputation, to p. 24 which one is not entitled, is called 'being covetous of fame". If I were to listen to your idea, then I fear I should be one, who covets both position and fame. Therefore, I dare not listen to your instructions.

Lord Shang said :

- Do you not approve of the way in which I govern Ch'in ?

Chao Liang replied :

- He, who hearkens with the inner ear, is a man of quick hearing, he who turns his eyes inwards, is a man of clear vision, and he who conquers himself is said to be strong. Shun of Yü (183) had a saying: «He who humbles himself is superior. » The best thing for Your Lordship would be to follow the Way of Shun of Yü. There is no need to ask me.

Lord Shang laid :

- Formerly, the Jung and Ti barbarians of Ch'in, in their teaching, knew no difference between father and son, and they lived together in the same room. Now I have altered and regulated their moral teaching and have made distinctions between men and women. On a grand scale I have constructed pillars for the publication of mandates, and have arranged things in the same way as they are in 
Lu and Wei. Seeing how I govern Chin and comparing me with Wu-ku-ta-fu (184), which of us do you think the abler ?

p.25 Chao Liang replied :

- The skins of a thousand sheep are not worth the armpit of one fox ; the silent approval of a thousand men is not worth the frank word of one scholar. Wu-wang became great because of the frank counsels of his ministers; Chou of the Yin dynasty perished because of the silence of his flatterers. If Your Lordship does not really disapprove of $\mathrm{Wu}$-wang, then I should like to ask permission to speak sincere words, during a whole day, without suffering punishment therefor.

Lord Shang said :

- There is a saying: Pleasing words are adorned, direct words are real; bitter words are medicine, sweet words cause disease. If you are really willing to set forth, for a whole day, your sincere views, it will be medicine to me. I want to serve you as my master, how can you then still further excuse yourself?

Chao Liang replied :

- Wu-ku-ta-fu was a rustic from Ching (185). When he heard of the ability of Duke Mu of Ch'in, he desired to see him, but as he had no travelling money, he sold himself to a stranger from Chin (186), wore a coarse shirt and fed oxen. After the lapse of a year, Duke $\mathrm{Mu}$ heard about it and raised him from beneath the mouths of oxen and placed him above the people. No one in the state of Ch'in dared feel offended at this. When he had been minister of Ch'in for six or seven years, in the east he had conquered Cheng, three times he had established a prince in Chin, and once he had saved the Ching state ${ }_{\text {p. } 26}$ from disaster (187). He issued his instructions within the borders of his fief, with the result that even the people of $\mathrm{Pa}$ (188) brought tribute; he showed his favours to the feudal lords and even the eight tribes of the Jung barbarians came to submit (189). Yu-yü (190), hearing about it, knocked at the barrier and wished to see him.

The way in which Wu-ku-ta-fu was councillor of Ch'in was, that, when he was tired, he did not sit in a carriage, in summer he did not spread out a sunshade, when he travelled in the country he did not have carts or mounts following him, nor men carrying shields and lances. His merits were preserved in the stores and granaries (191), and his virtuous conduct was displayed to later generations. When $\mathrm{Wu}$-ku-ta-fu died, the men and women of Ch' in shed tears, the children stopped singing, the threshers ceased to chant, while wielding their flails. Such was the virtue of Wu-ku-ta-fu (192). 
Now, as for you, you have been received by the Prince, because you had the favourite, Ching Chien, as your patron; therein lies nothing to give you a claim to fame. As councillor of Ch'in, you do not concern yourself over the people, but p.27 you grandly build pillars for the publication of mandates; therein lies nothing that gives you a claim to merit. You punished and branded the tutor and teacher of the Crown Prince, you afflict and wound the people with severe punishments - this piles up hatred and breeds disaster. Reforming the people, by instructing them, goes deeper than the mere issuing of commands; making the people imitate the good example of the ruler is more expeditious than issuing mandates. Your Lordship takes improper measures and makes external alterations, but there is nothing that can lay claim to the name of instruction. Moreover, your Lordship sits with your face to the south (193) and calls yourself "I, who am alone" (194) and daily you restrain the nobles of Ch'in more. The Shih-ching says (195) :

Look at a rat, it has its limbs - but a man shallbe w ithout cerem onial behaviour! A man who has no cerem onial behaviour, how is it that he does not die at once.

Looking at it from the point of view of this ode, there is nothing which gives you a claim to long life. Already for eight years has Prince Ch'ien (196) bolted his door and has not gone out. Your Lordship has also killed Chu Kuan (197) and branded Kung-sun Chia. The ode says (198) :

He who obtains men's favour, flourishes, he who loses men's favour, collapses.

p.28 In all these matters there is nothing that gives you a claim to having obtained the favour of men! Whenever your Lordship goes out, tens of carriages follow behind, the escorting carriages bear arms, and men of great strength and "with ribs joined together" (199) act as the third on the war chariots (200), men, who carry spears and bear halberds and lances, run alongside the carriages (201). Whenever one of these precautions should fail, your Lordship would certainly not go out. The Shu-ching says (202) :

He who relies on virtue, prospers, but he who relies on force, perishes.

Your Lordship's peril is like that of the morning dew. Do you still expect that your years will be prolonged and that your age will be increased! Why then do you not return your fifteen cities, and water your garden in a rustic spot, encourage the King (203) of Ch'in to bring to the front the scholars from their mountain peaks and grottoes, to nourish the old, to maintain the orphans, to respect 
fathers and elder brothers, to give rank to those who have merit and to honour those who have virtue, in order to have peace, to a slight extent. Your Lordship will still covet the riches of Shang and Yü, enjoy the privilege of instructing the state of Ch'in and accumulate the hatred of the people. But if the King of Ch'in should, of a morning, leave his guests (204) and no longer stand in the Court, how ${ }_{\text {p.29 }}$ slight would be the chance that the state of Ch'in would maintain your Lordship ! You would perish in no more time than is needed to lift up a foot !

The Lord of Shang did not follow this counsel, and, five months later, Duke Hsiao of Ch'in died, and the Crown Prince was set up as his successor (205). The partisans of Prince Ch'ien accused the Lord of Shang of planning a rebellion. Lictors were sent to arrest him, but he had fled to a place in the passes (206). When he desired to lodge at an inn, the innkeeper, not knowing that he was Lord Shang, said :

- According to the law of the Lord of Shang, whoever shall receive at his inn guests, who cannot be identified, will be punished (207).

The Lord of Shang heaved a sigh, saying :

- Alas, that the worthlessness of the law should reach such a point !

He left and went to Wei, but the people of Wei, who hated him for having tricked Prince Ang and for having defeated the hosts of Wei, refused to receive him (208). When the Lord of Shang p.30 wished to go to another country, the people of Wei said :

- The Lord of Shang is a rebel of Chin ; as Ch'in is a powerful country, when its rebels come to Wei, we have no choice but to send them back.

Thereupon, Lord Shang was forced to re-enter Ch'in.

As soon as the Lord of Shang had re-entered Ch'in, he hastened to the cities of Shang, and, combining with his followers, raised an army in these cities and marched to attack Cheng. Ch'in sent an army, which attacked the Lord of Shang and slew him at Min-ch'ih (209) in Cheng. King (210) Hui of Ch'in had him torn to pieces by chariots (211) as an expiatory punishment, saying :

— Let no one rebel like Shang Yang !

Thereupon, he exterminated the family of the Lord of Shang (212).

The Great Astrologer (213) says : "The Lord of Shang was naturally, in character, a hard and cruel man. When we find in his story that he tried to impress Duke Hsiao by the methods of the Emperors and Kings (we may be 
sure that) what he held forth was frivolous talk and did not represent his real nature. Further, after having succeeded in obtaining employment through the introduction of a favourite, he punished Prince Ch'ien, betrayed the Wei general, Ang, and ${ }_{\text {p. } 31}$ did not follow the advice of Chao Liang, all of which facts show clearly that the Lord of Shang was a man of little favour. I have read the books on "Opening and Debarring" (214) and on "Agriculture and War" (215), which are in keeping with the deeds he did. There is reason enough why he should have finally left a bad reputation in Ch'in.

\section{B. The Record of Shang Yang in the Chin-ts'ê (216)}

Wei Yang left Wei and went to Ch'in. Duke Hsiao made him Councillor and gave him as fief Yü and Shang. He was called the Lord of Shang. When Lord Shang governed Ch'in the laws were greatly practised; they were in the public interest and equitable, without favouritism, the punishments not sparing the strong and great, nor the rewards being exclusively bestowed on relatives and friends. The law even p.32 extended to the Crown Prince, whose tutors were branded and punished by the slicing off of the nose, and the feudal lords were fearful. After a year, things dropped on the road were not picked up, and the people did not take things improperly. His military equipment, both for defence and attack, was very strong. However, he was very hard, cruel and rarely bestowed favours. Especially did he make them submit by force. Duke Hsiao used him for eight years (217), and when he fell ill and did not get up, he wished to transmit the government to the Lord Shang, but the latter declined and did not accept it. After the death of Duke Hsiao, King (218) Hui became his successor and attended to the government. A short time afterwards, Lord Shang took leave and returned (219).

Somebody addressed King Hui, in the following terms :

- If a minister is too powerful, the state is in danger; if (a prince's) entourage is too familiar, his person is in danger. Now women and infants in Ch'in all speak of the law of Lord Shang and do not speak of the law of the Great King. Thus the positions are reversed and Lord Shang is made the ruler and the Great King is made the minister. Moreover Lord Shang is an old enemy of the Great King. Will it please Your Majesty to consider this !

When Lord Shang returned from his journey home, King Hui had him torn to pieces by chariots; nor did the people of Ch'in pity him.

\section{Historical Criticism of the Life}


p.33 The Biography of the Shih-chi, considered as literature, is an excellent piece of work. The Lord of Shang, as a man, stands out clearly before us : a brilliant, ambitious, unscrupulous, courageous politician, a man with an original, independent mind, a statesman of real vision. All the important incidents in this remarkable career are staged in a highly dramatic manner. The historian has felt that here were opportunities of the first rank for creating a dramatic effect. Here was Ch'in, struggling for supremacy, and on its borders the state of Wei, dominating the gate to the fertile plains in the east. Here was the man, who would show Ch'in the way to power and glory, who would utterly defeat Wei, would seize the irredenta west of the Yellow River and thus lay the foundation for the success by which Ch'in, a century later, would stagger the world. And this man was a renegade, a traitor. His home had been in Wei, he had moved among the nobles of Wei, he had distinguished himself in the service of the Chancellor, but he had been spurned by the Duke ! Not only had the Duke deemed him totally incapable of succeeding his master in high office, but he had not even deemed it worth his while to have him killed in accordance with the curious alternative, which his dying minister with his last breath had set him. Not fit to live, not even fit to die, and the young ambitious scholar had turned his face westward, with a grim resolution to make the Duke of Wei bitterly repent his terrible mistake.

Here was a life worth the pen of a master, and step by step we see it developing before our eyes. A picture full of colour ${ }_{\text {p. } 34}$ is drawn : we see Wei Yang, at his first audiences with the Duke of Ch'in, trying to gauge of what stuff this prince is made, and finding him fast asleep when he talks in the conventional manner. At last he has sized him up, he has discovered in him a man full of impatient ambition like himself; but lacking his intelligence and will-power. We see him eagerly and earnestly explaining his plans, sketching possibilities, and both become so absorbed in their conversation that etiquette is forgotten and the Duke does not even notice that the kneeling courtier, whom he has deigned to receive, has moved so far forward that his knees are actually on the mat on which he himself is seated. The decisive meeting is described, where Wei Yang in trenchant words ridicules the Duke's conservative ministers. Then power to realize his plans, a period of feverish activity, reform of the whole country in the teeth of opposition from all quarters, relentless execution of all his opponents and-supreme test of his power-punishment of the Crown Prince himself in the persons of his tutors. It is a period of preparation, of growing strength. Ch'in makes its power felt, it is recognized by the Chow ruler as the leader of the feudal lords, it presides over a meeting of the princes and there lays down the law, and Wei Yang triumphs. The feudal princes know that he is the ruling power in $\mathrm{Ch}$ 'in, his name is beginning to be terrible, far beyond the frontiers of Ch'in. And then he strikes. Ch'in's interest and his own vengeance are one : Wei must be destroyed. Personally he commands the army that invades Wei. He decoys the prince who leads the opposing forces ; they have been friends in the old days 
in Wei, but friendship is to him but an aid to vengeance. The prince is caught in a trap, ${ }^{3} 35$ swiftly and relentlessly he falls upon the unsuspecting army of Wei and deals it a deathblow. Wei's power is broken, its capital is removed to the other side of the mountain passes, and Wei Yang, now the Lord of Shang, is triumphant.

At the height of his power he is warned to beware. Proud and self-confident he scorns the warning. But the end is not far. His protector, Duke Hsiao, dies, and is succeeded by none other than the Crown Prince whom Wei Yang once mortally offended. A conspiration against him is formed by the nobles, who detest him ; he flies, and - victim of his own regulations against robbers and thieves - finds no shelter anywhere. He attempts a desperate stroke; he enters Wei and offers his services to the country which he once betrayed, willing to unmake the greatness of Ch'in which he alone has created. But Wei does not trust him and is going to extradite him to Ch'in. With a last desperate effort he makes his way to his own fief, assembles his adherents, invades the weak state of Cheng, in the hope of establishing himself there, but is surrounded by the pursuing troops of Ch'in and is killed in battle, brave to the last. A final gruesome touch is added : his body is torn to pieces by chariots and his family is exterminated.

What value should be attached to this romantic history? If we turn to the Annals for corroboration of the facts, we find that, apart from the Ch' in Annals, those of Ch'i, Ch'u, and Wei mention Shang Yang, as do also the Bamboo Annals. The Ch'i Annals, in connection with the conferring of the leadership on Duke Hsiao in 342, say that the latter in $342_{\text {p. } 36}$ took Yang, Lord of Shang, into his service (220); those of Ch'u mention the fact that in 340 Yang received Yü and Shang in fief $(221)$; in those of Wei is related how Prince Ang fell in the ambush which Yang had prepared for him and how Ch'in, thanks to him, extended its territory to the river; also they make mention of Yang's flight to Wei and the refusal of Wei to receive him (222). The Bamboo Annals finally confirm Wei Yang's invasion of Wei in 341 and his success : they also mention the conferring of a fief on Wei Yang, of which the name is given a little differently (223).

The Ch'in Annals (224) give some further details: Wei Yang's arrival in Ch'in in response to Duke Hsiao's appeal for scholars; his reform of the law and the discussion with the other ministers (225); the invasion by Wei Yang of Wei in 351 (226); the building of the new capital of Ch'in, its new administrative system, its land-reform, and the establishment of taxes (227); the defeat of Wei in 341 and the capture of Prince Ang (without, however, mentioning the ambush), with the subsequent ennobling of Yang to Lord of Shang; and finally his death and the incident with the Crown Prince in some detail. 
Unfortunately it is clear that the details, which the Chin Annals give, have no independent value apart from the Biography. They are certainly additions by Ssu-ma Ch'ien himself. Once, where he mentions the law reform, he refers the reader to the Biography, and the notice about Wei Yang's arrival in Chin, as well as the story of his disgrace, flight, p.37 and death, are certainly interpolations by the historian to the text of the Annals. In itself this text would deserve much confidence, as it was expressly spared from the Burning of the Books by Ch'in Shih huang-ti ; but Ssu-ma Ch'ien, who complains that it did not contain the dates by days and months and that it was brief and incomplete (228), seems to have felt called upon to improve and complete it. This is regrettable, as it makes it uncertain whether the other entries, in which Shang Yang plays a part, have not also been touched up. Yet, if this were so, one would expect that the historian, once having started, would have added still more from the rich material of the Life which he had in hand. The fact that he has not done so, but leaves the account rather meagre, tends to show that he only introduced and took leave of our hero in a somewhat impressive manner, with the aid of the material from the Life, but that he gave the rest as he found it.

The mere external facts of Shang Yang's life-his serving as a minister of Duke Hsiao, fighting with great success against Wei, the increasing power of Ch'in during the period when he was in power, and the building of a new capital - cannot reasonably be doubted. It is probable, but not absolutely certain, that we may add to this the important administrative reforms of the whole country, coupled with some sort of land and tax reforms.

As for the rest of Shang Yang's story, as embodied in the ${ }_{\text {p.38 }}$ Biography, it is not to be supposed that Ssu-ma Ch'ien composed this freely himself.

That was not his method. He took what material he found, used his own critical judgment, and made selections. We have seen how a part of the story, which he gives, is found in the Chan-kuo-ts'e and in the Lü-shih-ch'un-ch'iu, and this means that it was current before 238 B.C. It may well be that a kind of romance was written round Wei Yang as has been the case with Su Ch'in and others, as Professor Maspero suggests (229). But if this was the case, the remnants, as we find them in the Shih-chi and in these two books, show none of the contradictions and impossibilities which Maspero has so clearly demonstrated in the romance of Su Ch'in (230). They do not come into conflict with the main historical facts as such, but are chiefly literary embellishments of the dramatic moments. Of one of these we can even now trace the source, for, as we shall see below (231), the discussion with Kan Lung and Tu Chih on the reform of the law is merely taken from another famous discussion, viz. from that started by King Wu-ling of Chao in 307, on the adoption of barbarian clothes. As to the long conversation between the Lord of Shang and Chao Liang, it is an excellent rhetorical composition, embodying just the kind of criticism on Wei Yang which a Confucian scholar might make. 
It is therefore not necessary to reject entirely the light which this romantic account throws on the character and ${ }_{\text {p.39 }}$ reforms of Shang Yang. Evidently it goes back to an old tradition less than a century removed from himself; in Han Fei-tzu many of the same reform-measures are also ascribed to Shang Yang. A centralizing, strong, and severe government was evidently what was needed in those days of disruption and a struggle with the nobles and their privileges would be the necessary result for any statesman attempting such a policy. It is quite likely that various measures of different dates which helped to make the state of Ch'in what it later became, were all ascribed to one man, so that Shang Yang may have been credited with more statesmanship than he ever possessed. Yet we cannot disbelieve the strong and undisputed tradition, which makes him into the initiator of the strong policy which finally led to Ch'in's unparalleled success.

For the sake of clearness I summarize here the chief of these measures. Shang Yang is said to have converted Ch'in from a loose conglomerate of small feudal territories into a highly centralized administrative unity. He seems to have retrenched the privileges of the noble families, even of those of the members of the princely clan, and to have instituted a hierarchy of officials who had distinguished themselves in warfare. Severe punishments were enacted against brigands and the private fights of the semi-independent feudal cities, and a rigid bureaucratic organization into districts was instituted. The unity of the old patriarchal family-system was attacked by discouraging people from living together, and mutual responsibility was introduced, with rewards for indictment of crime. Tilling the soil and weaving were encouraged, and measures were taken against trade. $A_{\text {p.40 }}$ new system of taxes was introduced and weights and measures were standardized. A land-reform was put into force.

Whereas we shall later discuss the general, ideas of law, which were in the air towards the end of the fourth century B.C., and of which Shang Yang seems to have been a practical exponent in some of these measures, it may be useful first to examine some of the social reforms which seem to require some explanation and which may throw light on the text of the Book of Lord Shang. 


\section{CHAPTER II}

\section{SHANG YANG AS SOCIAL REFORMER}

\section{Shang Yang's Economics}

p.41 One of the great reforms for which Shang Yang has been made responsible is that which gave China individual land-tenure.

In ancient China only the nobles could hold land, either in large or small fief, or as a domain, usually connected with some office, of which they had the usufruct, and which was often, though not always, transmitted by heredity. The farmers did not possess the land which they cultivated. All the land was divided up into squares, which were subdivided into nine smaller squares, cultivated in common by a group of eight families. Eight of these fields were called "private", that is, although the work was done together, each family was entitled to the produce of one division; the ninth, which was in the centre, called the "public field", was cultivated entirely for the benefit of the overlord. This system is usually called the ching system, as the character ching, "well", written in a square, represents very clearly the division. It seems that the area of the ching varied in different parts of the Empire. In the royal domain of Chou, viz. in the valley of the Lo River, they were 1,000 $\mathrm{mu}$, each family having $100 \mathrm{mu}$ for cultivation and $5 \mathrm{mu}$ for house and garden. In some other parts there seem to have been $200 \mathrm{mu}$ for each family lot, in others again only $70 \mathrm{mu}$ p.42 for each. In the state of Chin the ching seems originally to have comprised only $400 \mathrm{mu}$, but gradually this system was replaced by the simpler method of allotting $50 \mathrm{mu}$ to each head of a family who had to cultivate $5 \mathrm{mu}$ as tithe (232). In practice this whole system amounted, indeed, as Mencius says (233), to the paying of a tithe. Mencius (234) draws an idyllic picture of the life of the farmer as it should be under the rule of a good king, where this system prevailed:

"Around the homestead, with its five $m u$, the space beneath the walls was planted with mulberry trees, with which the women nourished silkworms, and thus the old were able to have silk to wear. Each family had five brood hens and two brood sows, which were kept to their breeding seasons, and thus the old were able to have flesh to eat. The husbandmen cultivated their farms of 100 $m u$, and thus their families of eight mouths were secured against want.

But the actual condition of the farmers seems to have been far from idyllic and, in fact, to have constituted a grave problem. This is seen from an interesting calculation, which has been preserved in the chapter on Economics 
in ${ }_{\text {p.43 }}$ the Books of the Han Dynasty (235). It is said to have been drawn up by Li K'uei (236), a minister of Marquis Wen, of the state of Wei, Ch'in's neighbour, but it may have been composed somewhat later (237). The author reckons that one man has to feed five mouths, and that by cultivating $100 \mathrm{mu}$ of land, the average return would be 150 piculs (238); after deducting 10 per cent for land-tax, 135 piculs remain. Allowing 12 piculs per person per month, i.e. 90 piculs per year for a family of five, there is a surplus of 45 piculs. By reckoning the value of a picul as 30 coppers (239), this gives 1,350 coppers. For social obligations in the village (240), for the ceremony of the "tasting of the first grain", and for the sacrifices of spring and autumn, 300 coppers are required, leaving 1,050 coppers. Then allowing 300 coppers each for clothes, 1,500 would be needed for five persons, giving a deficit on the budget of 450 coppers, without reckoning anything for misfortunes, illness, or death.

In order to ameliorate the condition of the farmers, the ${ }_{\text {p.44 }}$ same author advised that the price of grain should be controlled, and that the government should buy up the excess supply in good years, so as to be able to meet the demand in bad years, at normal prices (241).

It may be supposed that the ching system, with the changing economic conditions of the people, had gradually lost its hold. As Maspero points out (242), it was well fitted for a time when the cultivation of the land was predatory, by burning the brushwood and moving to other fields as soon as, after a, few years, the land was exhausted. In such a system the formation of individual property was not possible, and the peasants moved in groups from one place to another ; later, in the historical period, the imperfect agricultural methods made frequent displacements necessary, in order to let the land lie fallow for some years. But as soon as the families became more settled on more or less definitely allotted land, the tendency to individual property began, and where the ching system changed its original character into the mere paying of a tithe, it may be assumed that there had been private transfer of land in such forms as the sale of the right of cultivation, long before the old system had been theoretically abolished.

Now the great reform which is ascribed to Shang Yang is the complete abolishment of the ching system and its replacement by that of individual property. However, neither in the Ch'in Annals, nor in his Life, is this clearly stated. The text merely says in a very cryptic manner that, 'in order to make arable lands the paths and furrows between the fields were p.45 opened up" (243). Yet in the history of the early Han dynasty it is said definitely (244) that

«Duke Hsiao, on the advice of the Lord of Shang, destroyed the ching system and opened up the paths and furrows between the fields.

And in a speech of the well-known Confucian scholar, Tung Chung-shu, in the time of Emperor Wu (140-87) it is said : 
«In Antiquity the people were only taxed one tithe. It was easy to supply what was required and if the people were employed for not more than three days, their work was easily sufficient. The people's resources were, on the one hand, sufficient to nourish the old and fulfil the duties of filial piety and, on the other, they were enough to serve the superiors and to provide payment of the land tax, while they were also sufficient to keep wife and children, and to fulfil the duties of love. Therefore the people were glad to obey their superiors. But, when the Ch'in dynasty came, this was altered. Applying the law of Shang Yang, the institutions of the ancient emperors and kings were changed, the ching system was abolished, and the people acquired the right to sell and buy (the land).

It is possible that these statements are based on parts of the original text of Shang-tzu which are now lost: In the present text of the Book no reference is made to this important reform. In paragraph 2, dealing with the cultivation of

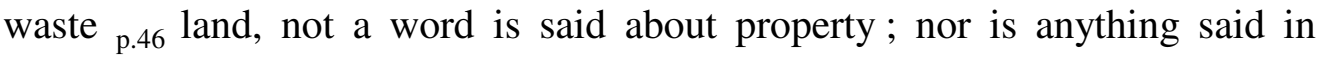
paragraph 15 , which deals with immigration. On the other hand, it is tacitly admitted at the end of paragraph 1, that some sort of land-reform was indeed Shang Yang's great innovation, for there it is said that, after the decision to reform the laws had been taken, Duke Hsiao "issued the order to bring waste land under cultivation". The Life speaks of "opening up the border -country", which also points to the cultivation of new, wild land. How far all this may have included, for the interior, the abolishment of the ching system, remains uncertain. We should remember that the existence of this system in $\mathrm{Ch}$ 'in, which came comparatively late within the Chinese sphere, is not at all well-established (245). Shang Yang may, however, have clearly regulated individual freehold of land, and may thus have attracted colonists. In that case it was another prerogative which he took away from the noble classes, who alone, as we have already seen, had so far held that right.

A new taxation system is supposed to have been connected with the reform. The Annals say that in 348 for the first time taxes, fu, were established, and in the Life it is said that the $f u$ and shui taxes were equalized (246). The accepted explanation of this phrase is that a tax was established proportional to the surface of the land, as distinct from the p.47 hitherto prevailing tax on the produce (247), so that the income of the state would be independent of the fluctuating returns of the harvest. It may, however, be questioned whether this interpretation is right. Granting that very unwise measures have often been taken, it does not seem to have been the most logical thing, from the point of view of promoting agriculture, to establish taxes ; which would lay a definite burden on the farmers, irrespective of the quality of the harvest. This would have led them rather to cultivate small lots of fertile land than to bring large stretches of new land into cultivation, which, for some years at least, were bound to give but a meagre 
return. Yet, if paragraphs 2 and 15 of the Book may be at all supposed to contain a certain tradition of Shang Yang's measures, cultivation of fallow land was his avowed policy. It is true, on the one hand, that, in paragraph $15 \mathrm{a}$ special freedom from taxes is promised to colonists, but on the other hand in paragraph 2 (p. 7) it is expressly stated that 'taxes should be levied according to the measure of grain". This last system would certainly seem to have been most favourable to the farmers. If, however, it is true that a fixed tag was laid on the surface; the possibility remains that the tag was sunk in the land and that the capitalized amount of the tax was subtracted from the value of the land (248). In this way it would not necessarily have been a heavy burden on the farmers. Personally I believe that the mention made of the taxes is connected with the preceding entry, relating to the new administrative unity of the land. p.48 Before this the farmers taxes had probably gone to the feudal lords ; from now on they were levied by officials and went straight to the granaries of the capital.

It is interesting to see what the Book has to say about the promotion of agriculture. Generally it admits no other occupations for the people than agriculture and warfare, and it proscribes all merchants, artisans, and scholars.

«If there are a thousand people engaged in agriculture and war, and only one in the Odes and History, and clever sophistry, then those thousand will all be remiss in agriculture and war; if there are a hundred people engaged in agriculture and war and only one in the arts and crafts, then those hundred will all be remiss in agriculture and war (249).

(The people)

« will be of no use, if they see that glib-tongued, itinerant scholars succeed in being honoured in serving the prince, that merchants succeed in enriching their families and artisans have plenty to live upon. If the people see both the comfort and advantage of these three walks of life, then they will indubitably shun agriculture; shunning agriculture, they will care little for their homes; caring little for their homes, they will certainly not fight and defend these for the ruler's sake (250).

Let the people be yoked to the land ; scholars, braves, artisans, merchants, all "can carry their personal capital round to any house on earth", for their capital lies in their ideas, their eloquence, their ability, etc. But 'the people's capital should be stored in the soil" and their life away from their home s should be made dangerous for them (251). p.49 They should not be allowed to migrate (252). Even the younger sons of the nobility should be made to farm and be kept from idleness (253).

Trade should be hampered as much as possible by heavy tolls, merchants should be made to serve and to live simply, heavy prices and taxes should be 
fixed for such luxuries as wine and meat, and trade in grain should not be allowed (254). The Biography (255) also speaks of tilling and weaving as the "fundamental occupations" and calls all other things "secondary". Those who occupy themselves therewith should be sold as slaves.

The ideal seems to have been to revert the entire economic life of the country from a money-basis back to a produce basis.

«The appearance of gold means the disappearance of grain and the appearance of grain means the disappearance of gold... (256) For every ounce of gold appearing within the territory, twelve piculs of grain will disappear abroad; but for every twelve piculs of grain appearing within the territory one ounce of gold will disappear abroad (257).

All export of produce is therefore pernicious.

«Therefore a state that imports products is strong and one that exports products is weak (258).

In curious antithesis to our later Mercantilists, who desired to heap up as much gold-as possible, p.50 Shang-tzu (259) considers full granaries the greatest guarantee of prosperity, and "even though the granaries are filled", one should "hot be negligent in agriculture".

The ultimate aim of the hoarding of all this grain is political strength. Grain had apparently always to be ready for the army, which was the only other field where the people should concentrate their activity. It is curious to read in paragraph 15 , which is certainly of much later date, how the difficulty is realized of combining both intensive agriculture and frequent warfare, as the same people had to be ready for both. Therefore it is there suggested that colonists should be attracted to the country by freedom from taxes and military service, so that the old population of Ch'in should be free to devote themselves entirely to warfare without detriment to the economic condition (260).

The solution is also sought in a judicious use of the available land. It is calculated that four-tenths of all the land should be made. into arable fields (261), and a territory of a 100 square $l i$ should support 10,000 soldiers for war (262). Then,

« when the army marches out, and grain is given them, there is still a surplus of riches (263).

p.51 In these statistical calculations there are echoes of the agricultural school of "Intensive Culture" which is currently ascribed to Li K 'uei (264). His name may be a mere ornament, yet we are safe to say that these ideas lived in Wei, or the name of a minister of that country would not have been connected with them. Shang Yang himself, who came from Wei, may have known them, but in any case Shang-tzu (265) must have belonged to the circle where such theories of land economics were elaborated. We saw how a farmer's budget 
was calculated by Li K'uei ; it may be interesting to give some of his views on the agricultural policy which a state should follow (266).

«Within an area of one hundred square $l i$ there are nine million $m u$. Leaving out of account the mountains, marshes, and city residences, one-third of this amount, there are six million $m u$ of arable land. If the people cultivate it intensely, each $m u$ can yield three additional pecks (267), and a like amount is lost in case of slackness. Therefore, even within an area of 100 square $l i$, the difference between an addition and a loss of grain will be $1,800,000$ piculs.

Li K'uei then goes on to show that if the price of grain were too high, it would hurt the consumers, and that if it were too low, it would hurt the farmers. If the consumers were hurt, the people would emigrate, and if the farmers were hurt, the state would be poor. So a high price and a low price both have bad results. Therefore $a_{\text {p.52 }}$ good statesman should keep the people from injury and give more encouragement to the farmers.

Then, after describing the miserable condition of the peasants, he goes on to expound a law for equalizing the price of grain :

«Those who want to equalize the price of grain must be careful to look at the crop. There are three degrees of good crops : the first, the second, and the lowest. In the first degree of good crops, the return is fourfold, so that there will be a surplus of 400 piculs (268); in the second degree of good crops the return is threefold, and there will be a surplus of 300 piculs (269); in the lowest degree of good crops, the return is twofold, and the surplus will be 100 piculs.

«In the first degree of failure of the crops (270) the return of the harvest is 100 piculs ; in the second degree of failure the return is 70 piculs; in the third degree of failure the return is 30 piculs. Therefore with a first degree of good crops the authorities should buy up 3 parts and leave the people 1 part (of the surplus); with a second degree of good crops they should buy up 2 parts and leave the people 1 part; with a third degree of good crops they should buy up 1 part (271). The purpose of this buying is to let the supply be just enough for the wants of the people, and it should be stopped when the price is normal. In a first degree of failure of the crops, p.53 the authorities should put on the market what they have stored during the third degree of good crops; in the second degree of failure they should put on the market what they have stored during the second degree of good crops ; and in the third degree of failure they should put on the market what they have stored during the first degree of good crops. In this way, in spite of failure of the crops and famine, floods, and drought, the price of grain is not high 
and the people need not emigrate, because the government takes the surplus of good crops to fill the insufficiency of bad years.

A few words may be in place here on the further agricultural development. After Ch'in Shih-huang-ti had brought the whole Empire under his sway he issued an order in 216, announcing that people should themselves declare the amount of their land, in order to regulate the land-tax (272). Henceforth private ownership of land was the rule throughout the country.

This fundamental change had consequences, which Shang Yang, if it is true that he initiated this policy, had certainly not foreseen. Instead of ameliorating the condition of the peasantry, it made it worse. The land was bought up by wealthy people and the mass of the people became poor tenants instead of free farmers. It had been thought that a low land-tag would be sufficient protection for the farmer, and now it turned out that the big landowners alone profited by it and the people groaned under heavy rents. The Ch'in dynasty fixed the land-tag as a $1 / 15^{\text {th }}$ of the produce, and this rate was maintained under the early Han dynasty, with even a decrease to $1 / 30^{\text {th }}$ under Ching-ti (156-141) (273). But in ${ }_{\text {p.54 }}$ spite of this the land question remained extremely grave throughout the Han dynasty.

In a famous piece of literature, written by the statesman Ch'ao Ts'o, an adherent of Shang Yang's school in the second century B.C. (274), the hardships of the peasants are described in eloquent words.

«Now in every family of five there will be at least two, who perform public services ; they will cultivate no more than $100 \mathrm{mu}$, the yield of which will be not more than 100 piculs. In spring they have to plough; in summer, to weed; in autumn, to reap; in winter, to store ; besides cutting fuel, repairing official residences and other public services. Exposed, in spring, to wind and dust ; in summer, to scorching heat; in autumn, to fog and rain ; in winter, to cold and frost - from year's end to year's end they know not what leisure means. They have besides their own social obligations, visits of sympathy and condolence, the nourishment of orphans, and the education of the young. Then, when flood and drought come upon them, already encompassed round with toil and hardship, the government pressing harshly, collecting taxes at unsettled times, issuing orders in the morning to revoke them at night - those who have grain sell at half value, while those who have not borrow at exorbitant usury. Then paternal acres change hands ; sons and grandsons are sold to pay debts ; merchants make vast profits, and even petty p.55 tradesmen set up business and realize unheard-of gains. Every day they loiter on the market-places of the capital, and, taking advantage of the oppression of the superiors, have double profit on what they sell. 
«That is why of the latter, the men do not plough nor weed, their women do not raise silkworms nor do they weave, and yet they all wear fine clothes and they live on the fat of the land. They share not the hardships of the husbandmen and yet they obtain the produce of the fields ....

«There would be nothing more presently advantageous than to concentrate the energies of our people upon agriculture ; and the way to do this is to enhance the value of grain by making it an instrument of reward and punishment. Let an order be now published throughout the Empire, that all district officials who bring in grain will receive titles and acquittal of punishment (275). By these means, rich men will enjoy honours, husbandmen will make money, and the grain will have an outlet. Those who purchase rank in this way will purchase out of their surplus; and by handing this over to the Imperial exchequer, the burden of taxes of the indigent people may be lightened ; this may be called to take from one man's superfluity to make up for the deficiency of another. . .

Tung Chung-shu, in the same speech from which we quoted before (276), finds the cause of all this misery in the abolition of the ching system. After having said how the people obtained the right to sell and buy their land, he goes on :

«The fields of the rich continued uninterruptedly their paths p.56 and furrows (277), but the poor had no place to stand up a needle. Also the profit from streams and morasses was monopolized and the fertility of hills and forests was controlled; licentiously all restrictions were exceeded and there was rivalry in wastefulness. In the cities there were people as much honoured as princes and in the hamlets there were people as rich as dukes and marquises; how then should the lower people not be in hard straits ? .... Therefore the poor people often wore the clothing of oxen and horses, and ate the food of dogs and swine .... At the rise of the Han dynasty all this continued without reform .... Although it is impossible to revert entirely to the old ching system of the fields, yet we should more or less approach antiquity, and limit the appropriation of land by private people so as to subvent those who are in want....

For Confucianists like Tung Chung-shu the ching system had become part of the hallowed institutions of a revered antiquity. More than once in the course of Chinese history efforts have been made for its partial re-establishment, such as, for example, the reforms of Wang Mang (9 A.D.), who aimed at land nationalization. It is, however, outside the scope of this introduction to follow up a development which is full of interest. 


\section{Shang Yang's System of Rewards and Punishments}

The social organization connected with the ching system ${ }_{\text {p.57 }}$ was as follows : a ching consisted, as we have seen, of eight families ; three chings, said to be 25 families, were grouped together around an Altar of the Soil, shê, and formed a $l i$. Or differently divided, a $l i$ comprised five neighbouring districts, lin, each composed of five families (278). In an interesting paragraph in the Han-shih-wai-chuan (279) the ideal relationship which existed between the inhabitants of these hamlets is described.

« The eight families protected one another, outside and inside they took turns in keeping watch, in sickness they condoled with each other, in distress they assisted one another, those, who had, lent to those, who had not, on festive occasions they invited each other, they arranged marriages for each other, they shared the results of fishing and hunting, they showed each other benevolence and kindness and thus the people lived in harmony and intimacy and loved each other.

But then it continues :

« Now the people in groups of five are responsible for each other's crimes, they spy on each other to discover transgressions, they denounce each other and cause hostile relations. By thus establishing enmity the people harm each other, they injure friendly feelings, destroy benevolence and kindness and damage scholarship and culture. Those of friendly spirit are few, but those who ${ }_{\text {p. } 58}$ desire to cause harm are many, and the way of virtue has been destroyed ...

It would seem as if here is given a description of the state of affairs as desired by Shang Yang. For, as we have seen (280), the reform which came before all others was the organization of the people into groups of five or ten men, who were mutually responsible for each other, and were obliged to denounce each other's crimes; at the same time the old patriarchal family-system was broken up. In the Life this measure is not mentioned in any relation with the abolition of the ching system, but it fits in very well with that reform.

The oldest testimony, from which Ssu-ma Ch'ien may have drawn for his account of this measure, is Han Fei-tzu, who twice (281) mentions this law.

«Kung-sun Yang in ruling Ch'in, established the system of denunciation of crime in which (for the non-denunciation) one was punished as if one had committed the crime oneself; he organized groups of ten and five men who were all held equally responsible for each other's crimes. 
The Book is not so explicit. In the apparently old par. 19 it is said (282) that « in battle five men were organized together into a squad; if one of them was killed the other four were beheaded,

but this is a military measure which cannot have been applied in every-day life. In par. $18(\underline{283})$ it is also said that :

«by the order in the ranks they should be organized into bands of five.

But in the same paragraph (284) it is stated : $p .59$

«All should control one another by means of the law and correct one another by means of mandates,

and in par. 24 we read (285) :

«In a condition of complete good government, husband and wife and friends cannot abandon each other's evil, cover up wrong doing and not cause harm to relatives, nor can the men from the people mutually conceal each other from their superiors and government servants.

These two paragraphs cannot, however, be considered as belonging to the old part of the work (286). In par. 2, which is older, it is said (287) that relations should be involved in the punishment, and the expression used might just as well mean that those of the same group should be involved in the punishment. In par. 5 it is clearly said $(\underline{288)}$ :

«If they make it their habit to denounce all crimes, then the people make the judgments in their own minds, and if, when the ruler gives his orders, the people know how to respond, so that the means for enforcing the law are really manufactured in the families and merely applied by the officials, then the judgments over affairs rest with the family. Therefore, in the case of one, who attains supremacy, judgments with regard to punishments and rewards rest with the people's own minds, and those with regard to the application of the means for enforcing the law, rest with the family.

So not the officials of even quite small administrative units of ten or five hamlets should decide people's merits and demerits, but the latter should themselves do so (289). Rewards and punishments should be so definite and clear that everybody should know at once the consequences of his own or of his neighbour's actions.

p.60 Now these punishments are meant to be deterrent in the highest degree. 'Punish severely the light crimes", such was the law of Kung-sun Yang, says Han Fei-tzu in his important $30^{\text {th }}$ paragraph (290), and in the explanatory part of that same section it goes on : 
«If small offences do not arise, big crimes will not come and thus people will commit no crimes and disorder will not arise.

In the oldest sections of the Book we find this phrase repeated ad nauseam, and it is stated again and again that the result will be that punishment will be no longer necessary as nobody will dare to commit the slightest offence. The same phraseology recurs also in Kuan-tzu (291) :

«If one desires the people to be correct, it is necessary to prohibit small offences, for big offences originate from small ones. If small offences are not prohibited, it is impossible to obtain that big offences shall not harm the state (292).

The Life says that even the omission to denounce a culprit was punished by being cut in two; and for concealing a culprit one received the same punishment as he who surrendered to the enemy. The Ch'ien-han-shu (293) adds to this that Shang Yang used the punishments of branding on the top of the head, extracting the ribs, and boiling in a cauldron.

In the Biography of the Shih-chi it is asserted (294) that Shang Yang did not hesitate to punish the crown-prince himself ; the account in the Chan-kuo-ts' $\hat{e}$ states (295) a even more clearly that 'the punishments did not spare the strong and great".

p.61 Not less curious than his system of punishments was the system of rewards which Shang Yang is reputed to have initiated. The Life tells us (296) that

«those who had military merit all received titles from the ruler according to a hierarchic ladder », and

« whosoever should denounce a culprit would receive the same reward as he who decapitated an enemy.

The Book also says that

«in the case of one who attains supremacy ... rewards are bestowed on the denouncement of villainy, so that minor sins do not escape unnoticed (297).

In Han Fei-tzu we receive a little additional information on this point. He mentions as one of Shang Yang's measures 'to reward the denunciation of crime" (298) and writes also (299):

« The law of the Lord of Shang said: 'He who cuts off one head is given one degree in rank, and those who desire to become an official obtain an office worth 50 piculs. He who cuts off two heads, is given two degrees in rank, and those who desire to become officials are given an office worth 100 piculs."

We are fortunately somewhat informed about this curious hierarchy of henchmen and denunciators. It was, in fact, the beginning of an institution 
which has been perpetuated throughout the course of Chinese history down to modern times, viz., that an officer, apart from the real office which he fills, holds a nominal rank which is purely honorary. As Chavannes remarks (000), these ranks were not unlike the chin of the former Russian administration. The hierarchy numbered 18 degrees, and when Ch'in Shih-huang-ti had destroyed feudalism in the whole country, two new degrees ${ }_{\text {p.62 }}$ were added to these, which were given to former feudal lords who had become high dignitaries. The Ch'ien-han-shu (301) gives a summary of the organization as it existed during the early Han, and as it had been taken over from the Ch'in dynasty. The 18 degrees which concern us here are the following:

1. kung-shih; i.e. in distinction from ordinary shih "patrician", they receive the honorary appellation of kung "official".

2. shang-tsao; i.e. the Emperor, shang, had made, tsao, the decree by which they received this title.

3. tsan-niao ; lit. "horse with a silken harness" ; which those who had this title were entitled to mount, as in modern times purple or yellow bridles were conferred by the Emperor.

4. pu-keng ; the holders of this rank were free from keng, police-duties.

5. ta-fu; the holders of a simple rank of $t a-f u$, Grand Officer.

6. kuan-ta-fu.

7. kung-ta-fu.

8. kung-ch'eng ; the holders of this rank were entitled to mount, ch'eng, an official, kung, carriage.

9. wu-ta-fu ; Grand Officers of the $5^{\text {th }}$ degree.

10. tso-shu-chang; the "left head of the multitude".

11. $y u$-shu-chang; the "right head of the multitude" (302). p.63

12. tso-keng.

13. chung-keng.

14. yu-keng (keng meaning here to command the police).

15. shao shang-tsao.

16. ta-shang-tsao ; the holders of these two ranks, junior and senior, seem to have had authority over the ordinary shang-tsao, those who held the second degree.

17. ssu-chü-shu-chang; this gave the right to mount a carriage with four horses, ssu-chü.

18. ta-shu-chang. 
Altogether these 18 degrees formed 9 groups, which were known as the chiu-ch'ing.

In this system there is evidently no place left for feudalism. The Life says (303):

«Those of the princely family, who had no military merit, could not be regarded as belonging to the princely clan. He made clear the distinctions between high and low, and between the various ranks and degrees, each according to its place in the hierarchy .... Those, who had merit, were distinguished by honours, while those who had no merit, though they might be rich, had no glory whatever.

This made a clean sweep of all privileges by birth.

In the $19^{\text {th }}$ paragraph of the Book of Lord Shang several of these degrees are mentioned as being given for military merit. In a somewhat doubtful passage (304) it is also said that a man who could capture a head was exempted from taxes ; for the capturing of the head of a man of rank, land was given, apart from one degree in the hierarchy, and also a bodyguard for each rank (305). Han Fei-tzu, in the passage (306) mentioned before, ${ }_{\text {p.64 }}$ criticized this system of rewards not without a touch of humour, referring in particular to the possibility of obtaining a real office in this manner. He says :

«Thus promotion in rank and. office correspond to the merit acquired in cutting off heads. Now suppose there were a law that those who cut off a head are ordered to become doctor or artisan'; then houses would not be built nor would sickness be cured. Indeed, an artisan has skill in his hands, and a doctor prepares drugs, but if one is set to do these things because of merit in cutting off heads, then one does not have the required ability. Now for filling office knowledge and ability are necessary, and the cutting off of heads is the result of courage and strength, and if offices for which knowledge and ability are necessary are filled according to the results of courage and strength, it is exactly the same as if those who had merit in cutting off heads became doctors and artisans."

The sanguinary exploits which originally alone constituted a claim to these ranks, were later replaced by the more peaceful method of buying a degree by means of a contribution in grain. In the Annals of the Ch'in dynasty this is for the first time clearly stated in the year 243 , where it is said :

«All those who brought 1,000 piculs of grain were awarded one degree of rank (307).

In the Han dynasty at various times the same system has been followed. We have seen (308) how Ch'ao Ts'o, in order to promote agriculture, suggested that titles should be awarded to those district officials who brought grain, and in the chapter on economics in the Shih-chi ${ }_{(309)}$ it is said that those who sent 
grain to the frontier, where it was ${ }_{\text {p.65 }}$ needed for the garrisons, obtained ranks up to the 18th, that of ta-shu-chang. This is explained as meaning, that for 600 piculs the degree of shang-tsao (the $2^{\text {nd }}$ ) was given, for 4,000 piculs that of $w u$-ta-fu (the $9^{\text {th }}$ ), and for 12,000 that of ta-shu-chang.

The various ways in which, in later times, rank and office have been for sale, need not detain us here, where we are only concerned with the origin of the custom, which became a vice. For the right understanding of the Book of Lord Shang one should, however, keep this system in mind. Repeatedly it is said (310) that office and rank should only be acquired through one opening; viz. that of war and agriculture. Apart from military merit, agricultural success can give a claim to rank.

When the army is mobilized for an offensive, rank is given according to military merit, and, reliance being placed upon the military, victory is certain. When the army is in reserve and agriculture is pursued, rank is given according to the production of grain, and, reliance being placed, upon farming, the country will be rich (111).

Already in the Book there are traces that this last method developed into simply buying office. Once it clearly stated $(\underline{312})$ :

«If the people have a surplus of grain, cause them to obtain office and rank by means of their cereals.

In the policy which is developed in the Book, the rank conferred would, on the one hand, constitute a reward, while on the other, it would impoverish the rich people, who otherwise, remaining wealthy, would fall into the snares of culture, or, to speak in the Book's vigorous terminology, would become addicted to the six 'Lice". 


\section{CHAPTER III}

\section{THE BOOK OF LORD SHANG and THE SCHOOL OF LAW}

\section{The Makers of the School of Law}

p.66 The first attempt at classifying the mass of philosophical writers which had come down from antiquity, in which mention is made of the School of Law, was made by Ssu-ma T'an, the father of the great historian, Ssu-ma Ch'ien (313). In the $130^{\text {th }}$ chapter of the work of his son, a small treatise from his hand has been preserved. It was written, in order to prove the superiority of Taoism, in which he was himself especially interested, over the other doctrines of the day, but the interest here lies in the fact that he gives a brief analysis of each of the rival schools. He mentions six schools altogether, which are: (1) The Taoist School; (2) that of Yin and Yang, or of the Philosophy of Nature ; (3) that of the $J u$, or the Confucian School ; (4) that of Mo-tzu, i.e. the philosopher, Mo Ti ; (5) that of Names or Terminology ; and (6) the School of Law.

p.67 Ssu-ma T'an regarded this last school very critically, though he was broad-minded enough to recognize its good points.

«They do not distinguish between relations and strangers, and make no difference between noble and low. All were in the same manner judged by the law, so that the virtue of loving one's relatives and honouring the honourable disappeared. Their doctrines might be practised for a certain time and for a definite purpose, but they should not be put into practice for ever. Therefore I say, that they are severe and are wanting in virtue. However, the fact that they clearly established the differences between the honoured position of a ruler and the low state of a subject, so that their respective functions and duties cannot get entangled, cannot be undone by a hundred schools.

The next great classification, which has come down to us in great detail, is the famous catalogue of books in the History of the early Han dynasty (314). It is based on a division, made by Liu Hsin, the son of Liu Hsiang, who had so large a share in the collation and preservation of books in the days of Ch'eng-ti (B.C. 32-6). Liu Hsin, who at his father's death was ordered to continue the work, made a division under seven heads, one of which included the "Various Philo sophers". In the Han History, Pan Ku subdivides these into ten schools, adding to the six already mentioned above those of the political philosophers, the Eclecticians, the agricultural writers and the minor 
narratives. With the omission of the last-named unimportant section, these schools are often spoken of as the "Nine Schools".

p.68 In the critical note attached to the list of authors, belonging to the School of Law, it is said :

«The School of Law originated with administrative officials. They made promises of rewards trustworthy and penalties definite, in order thereby to give a support to rites and institutions. The I-ching says: "The former kings caused their laws to be followed by making punishments clear." Th is is their good side. But when their doctrine was practised by cruel men, they opposed culture, they eliminated benevolence and love, they relied solely on penalties and law, and wished in this way to bring about order, with the result that cruel harm was done to the nearest relatives, kindness was injured, and for generosity came strictness.

The authors which the Han Catalogue mentions as belonging to the School of Law are the following :

* Li-tzu (315), in 32 sections ;

* the Lord of Shang, in 29 sections ;

* Shen-tzu (316), in 6 sections ;

* Ch'u -tzu (317), in 9 sections ;

* Shen-tzu (318), in 42 sections ;

* Han-tzu (319), in 55 sections ;

* Yu Hsi-tzu (320), in 1 Section; .69

* Ch'ao Ts'o (321), in 31 sections ;

* the Ten Affairs of Yen (222), in 10 sections ;

* the Sayings of the School of Law (323), in 2 sections.

In the Catalogue of the History of the Sui dynasty only three of these authors are mentioned under the heading of the Law School, viz. Shen Tao, Han Fei-tzu, and the Lord of Shang. But another important writer is added to their number, that is Kuan-tzu (324), who in the Han Catalogue figured under the Taoist authors. Since then he has been counted as belonging to the School of Law; in the Great Catalogue of the Imperial Library, the Ssu-k'u-ch'üan-shu, compiled under Chien Lung, he is also registered as such. There we also find counted as belonging to the Law School another philosopher, whom the Han Catalogue had listed as one of the Terminologists, viz. Têng Hsi-tzu.

Both Kuan-tzu and Têng Hsi-tzu belong to China's oldest law-makers. Kuan-tzu, whose real name was Kuan Chung, with the appellation I-wu, was the minister of Duke Huan of Chi (685-643), and is said by his counsels to have made Chi the leading state of his day. Têng Hsi -tzu lived in Cheng (325), in the second half of the sixth century B.C. He was a contemporary of another famous statesman, Tzu Ch'an, who is said to have composed the first penal code, which was p.70 engraved on iron tripods. Têng Hsi-tzu rewrote this code 
on bamboo tablets. In 501 he was executed by Tzu Ch'an's successor in the highest office (326).

It would be extremely interesting if the books, which now bear the names of men who lived in such a remote period, could be accepted as genuine. Unfortunately this is not the case. The book mentioned in the Han Catalogue as Têng Hsi-tzu was probably composed in the third century B.C., and the work now extant is of doubtful authenticity (327). Nor can we trust the authority of the great work, in 24 books, known as Kuan-tzu. Opinions on the value of this book have differed widely; I believe, however, that we do not go far wrong if we date the composition of the original work in the last part of the fourth century B.C. However, the book, as it now exists, is so mixed up with later additions, that its old elements can only be recognized with great difficulty (328).

It is very significant that these two last-named books were classed by the Han Catalogue as belonging respectively to the School of Terminologists and that of Taoists. For, indeed, the School of Law was not a real school in the sense that it claimed a founder, but it merely represents the outcome of various currents of thought which in their practical application stressed the importance of the Law. Its authors, therefore, ${ }_{\text {p.71 }}$ present certain aspects which justify their classification under other schools, especially of the two just named.

Fortunately we know something of the way in which these various streams of thought met and intermingled. We are able to localize some places, where it is certain that several representatives of very different ideas have met and talked, and we obtain some curious glimpses of the environment and conditions in which these scholars lived, who, together, have done so much to form the Chinese mind. There are two centres, which, for us, are important. One was in the state of Wei, at the court of King Hui (329), a prince who had had a very chequered career. After a brilliant beginning, he had been repeatedly defeated, both by $\mathrm{Ch} i$ and $\mathrm{Ch}$ in ; his crown prince had been made prisoner, and he had been obliged to cede to Ch'in all the territory which he possessed west of the Yellow River. In consequence he had even removed his residence eastward to what is now K'ai-feng-fu. Although he had adopted the royal title in 335 , he had preferred in his old age to keep aloof from politics as much as he could, merely trying to keep his fallen fortunes from further ruin : Instead he showed a philosophical interest in the problem of government and encouraged scholars to come to his court, thereby perhaps hoping to obtain some glory.

Here it is that we meet Mencius, in the opening paragraph of whose works is recorded a famous discussion with this king. It is said that in 333 a position at this court was offered to the great Taoist, Chuang-tzu, who, however, refused. The ${ }_{\text {p.72 }}$ greatest sophist of the time, Hui Shih (330), held however a position as councillor here ; with Chuang-tzu he had many controversies and must have baffled the King with his curious paradoxes. His tradition was 
continued later, in the first part of the third century, by Kung-sun Lung (331), who startled the world by his exercises in logic, launching such statements as "a white horse is not a horse". Here (332) also came the celebrated author of a system of natural philosophy, Tsou Yen (333), and the famous sophist Shun-yü K'un (334).

It is perhaps not too risky to suppose that some of the ideas of the School of Law were developed in this intellectual sphere. For it is very striking that all the books, which in the Han Catalogue are mentioned under this heading, of which we know anything at all, are ascribed to men who lived either in the three succession states of Chin, or in the neighbouring Ch'in. Li K uei had been minister to Marquis Wen of Wei (424-387), and it may well be that the book, which stands to his name, but which is probably not his own, was composed in his home country about this period. Shen Tao ${ }_{\text {p. } 73}$ was born in Chao in the fourth century, but it is true that we know of him that he formed part of the association which enjoyed the protection of King Hsüan of Ch'i (335). Shen Pu-hai, however, was a minister of Han between 351-337, and between 361-338 lies the brilliant career of the Lord of Shang in Chin (336). The greatest of all this group, Han Fei-tzu (337), was also a man from Han, and from the way he frequently refers to the books of the Lord of Shang, of Shen $\mathrm{Pu}$-hai, and also of Shen Tao, one has the impression that there certainly was a local tradition. It is of course not likely that either Shen Pu-hai or Lord Shang wrote anything themselves, but it may be supposed that the books to which their names were attached were evolved in the favourable atmosphere created by King Hui's protection of scholars.

The intellectual life in this circle was the more animated as it had numerous contacts with another and still more famous centre of scholars. This was the celebrated academy at the gate of Chi (338), in the state of Ch'i, in the East. Here during the second half of the fourth century B.C. and at the beginning of the third century, were assembled several of the leading minds of the times. There came Tsou Yen, a man loaded with honours ; and Shun-yü K'un, both of whom we have already met with at the Court of King Hui ; Tien P'ien, "with the p.74 divine mouth" (339), a philosopher with Taoist tendencies, but also, according to Hsün-tzu, interested in the study of terminology and law, and mentioned by him in one breath with Shen Tao (340); there was also the latter, who had come from his native state of Chao, also a Taoist; there was P'eng Mêng, the master of T'ien P'ien, who is said not to have been a good student; there was Yin Wên-tzu (341), a little younger than the others, also a Taoist, but keenly interested in the problems of terminology, and Sung Hsing (342), a great pacifist and disciple of Mo Ti. All these scholars lived in a kind of academy, which King Hsüan of Chi (319-301) had built for them and where they received rich subsidies. There were not less than seventy-six of these privileged scholars, who, as a sign that they belonged to the "Association of the Hua Mountain", as they called it, wore a special cap, flat at both top and bottom (343). At some time Mencius himself formed part of this brilliant company, and perhaps even Chuang-tzu. It is said that several 
thousands of scholars flocked together, attracted by the fame of these leading men and by the favourable treatment which they received at the hands of the p.75 king. We know that Hsün-tzu (344) came, probably as a young man ; and his eager and unformed mind better understood some of the discussions that took place, than the less profound and already mature Mencius, who, however, was also affected by them (345).

The personality of Hsün-tzu is of particular interest, because he forms a link between the older and later jurists ; as the greatest jurist of all, and the one whose woks have come down with the highest degree of reliability, Han Fei-tzu, is said to have been a pupil of Hsün-tzu.

\section{The Original Ideas of Shang-tzu}

Let us now first examine the political conditions in which the ideas of the School of Law developed. Its rise falls entirely within the fourth and third centuries B.C., in the important period known as that of the Warring States. These times were exceedingly troubled. The power of the Son of Heaven, the King of Chou, had become entirely nominal. The feudal lords behaved like independent princes, even going so far as to assume the title of king. The various states were engaged in incessant warfare and small states were constantly being annexed by powerful neighbours. Even the fate of big and

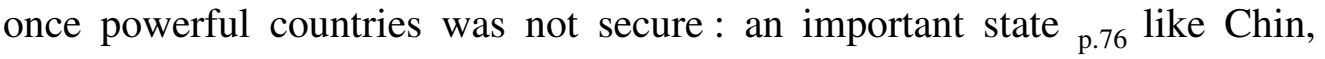
which for a time had held supremacy over all others, had come to ruin and had been divided, in 376, into the three states of Han, Wei, and Chao. It seemed impossible to reach a political equilibrium. Truly the time-honoured philosophy of the "A ncient Kings", who had been able to pacify the whole empire, no longer seemed to hold good. Conditions had changed too much from those of antiquity ; men were perhaps less good than they had been, and the need was felt of a system of practical, realistic politics.

In such a world the ill-success is very clear of a man like Mencius. Mencius was the dignified champion of tradition in this world of changing values. In one important point he had compromised with the existing state of affairs : whereas Confucius had still regarded the King of Chou as the only legitimate ruler, and had condemned all usurpation of royal power by the feudal lords, even Mencius had accepted the fact that the Chou house had lost all real power, and he was willing to recognize any ruler as supreme lord who proved himself worthy of the government over the empire. The necessary qualities which such a ruler should have, were, however, in Mencius opinion, moral virtues. This doomed him to ill-success, for what the princes desired was, on the contrary, power and profit. Very clearly is shown the divergence of ideas between Mencius and the ruling powers of his day, in the opening phrase of the conversation with King Hui, which I have mentioned (346) : 
— "Venerable Sir", the King greeted him, "since you have not counted a thousand miles too far to come here, may I suppose that you also have ${ }_{\text {p.77 }}$ something with which you may profit my kingdom?

Mencius replied :

- Why must Your Majesty necessarily use this word 'profit'? What I also have, are only these two topics: benevolence and righteousness, and nothing else.

King Hui, with his long and bitter experience of real politics, may have smiled at these words.

For indeed, a system of politics for the feudal lords had of necessity to be very different from that required by the Son of Heaven : The latter's interest was bound up with the maintenance of the immemorial customs which had come down from antiquity and upon which his own position rested. He reigned over the T'ien-hsia, "What-is-under-heaven", by virtue of his heavenly mandate, that is, his rule comprised the entire civilized and known world, and he reigned in accordance with the Tao, the Way of Heaven. He was the direct descendant of Shang-ti, the Emperor-on-High (4ㄱ) and King by right of natural law, by which he had been set up as guardian over the moral values which emanated from it. His was the care of the observance of the traditional $l i$, the rites, the customs, the right behaviour, the entire complex of cultural accomplishments. By himself meticulously observing the numerous rules and taboos which dominated the life of a king and which played their necessary part in the heavenly ordinance and in the order of the Universe, he was able to exercise a transforming influence on the world and to secure the essential harmony between worldly affairs p.78 and the Way of Heaven, thus bringing about peace and prosperity for all.

The Empire, under the rule of the King, was not a thing created by men ; it existed by the same natural necessity as did the human family, and it was governed by the same natural law ; from which all moral law was derived. In both public and private life the same standards held good, the one being merely an expansion of the other. Moral virtue, inherent in man, was the basis of all conduct in both spheres of activity, and, like the father in the family, the ruler punished all deviation from the natural standard for people's behaviour : Thus the Empire was not a separate organism, serving purposes of its own, but was merely an organized human society, following the law of Heaven like individual men ; it was a social and religious, not a political, entity.

The Son of Heaven delegated his power over the T’ien-hsia to members of the great families by a religious ceremony, which constituted investiture : he handed to them a clod of earth taken from the Altar of the Soil (348). The feudal lords governed in his name and by his authority ; they had no sacred position of their own. However, as the royal power weakened, especially from the end of the eighth century, great power was concentrated in the hands of some of them. They formed leagues, of which the most powerful was the head. But 
they were always anxious to obtain the royal sanction on their actions and had themselves appointed as $P a$, 'Lords Protector'. So the wars which they waged for ${ }_{\text {p.79 }}$ self-aggrandisement were carried on under the guise of being in reality the wars of the Son of Heaven. War was originally the punishment of rebels by the Son of Heaven, it was his ultima ratio to recall a refractory rebel to his duty, as the term for such wars itself testifies (349). The powerful $P a$ became, as it were, the executioners for the King, his right arm. Down to practically the end of the Chou dynasty this need of royal sanction was felt ; we have seen that Duke Hsiao of Chin thought it worth his while to obtain an appointment as Po after he had de facto established his supremacy over the other feudal lords in 343.

However, these sanctions had become more and more a mockery. The royal power continued to shrivel up, and with the advent of the period of the Warring States none of the feudal lords was powerful enough to uphold a semblance of central authority. Several states contested with each other for the supremacy, in never-ending conflict. From the moment that the feudal rulers began themselves to adopt the title of King, the fiction of unity of All-under-Heaven was lost (250). The usurped title showed their ambition to acquire supremacy over the world, and instead of sanctioning their wars of aggrandisement any longer by the semblance of upholding the authority of the reigning Son of Heaven, they did so by the usurpation of the very title which betokened supremacy and entitled to homage from all the other lords. In the course $_{p .80}$ of the fourth century about seven different feudal lords took the title one after another and conflict between their rival ambitions was inevitable. It was, between them, a constant life and death struggle. Their wars, however, could no longer have even the appearance of punitive expeditions ; they became contests for power, with the definite imperialistic end in view of attaining the supreme Kingship. These states, having practically abandoned their fealty to the Overlord, became by the very nature of things militant ; war became a necessity instead of a punitive measure, and the kuo, or feudal state, becoming independent, was entirely conceived under a military aspect.

So real, concrete power is the thing these rulers are, above all, interested in. Power becomes the new source of their authority. They have little use for tradition; they feel themselves hampered in their career by old customs and immemorial institutions, by privileges of the noble classes, which are almost insurmountable. All these things belonged to the old order which was passing, and inevitably we find strong statesmen, as Shang Yang is said to have been, engaged in curtailing the privileges of the nobles (351). With the example of the disintegration of the Chou house before his eyes, and seeing how Chin had fallen to pieces because it had not succeeded in curbing the power of the noble families, an intelligent statesman could not but aim at the centralization ${ }_{\text {p.81 }}$ of power in the hands of the ruler. Moreover, the code of conduct of the patricians ultimately recognized the Son of Heaven as the highest authority. It was imperative to replace this by the authority of the ruler of the state. They should be made to obey his will. Instead of drifting along the old ways, new 
systems, new methods of government had to be created. The old customs and rites, which were based on natural law, were replaced by laws, made by men. Law, having been applied theoretically only in order to enforce the observance of the standards set by natural moral law, now became the instrument for enforcing the standard set up by the state. Here came a clash between law and moral tradition. Never had this idea of law anything to do with the codification of the conceptions of justice living in the hearts of the people ; it was merely penal laws and institutions, deemed expedient for the government's centralizing and imperiali stic purposes; it was the expression of the state's own growing self-consciousness. It is very remarkable that, when we find the necessity for publishing the laws urged, it is not, as elsewhere, an expression of the popular wish to safeguard the people's rights and privileges for the future; on the contrary, it is the government itself that desires their publication as a safeguard of its own power, as it expects that the laws will be better observed, if people know exactly what punishments the non-observance will entail. Consequently, to have a deterrent effect, the laws have to be severe.

In trying to reconstruct what the necessities of the times seem to have required, I have already entered upon a discussion of the ideas of the Book of Lord Shang. For indeed, p.82 in its oldest part (352), the Book faces these fundamental problems, with a rare consistency. In extremely brief and sententious phrases, the unknown author expresses ideas, which must have been, more or less clearly, in the minds of many ambitious statesmen of his day, and follows up to their extreme consequences the principles which they applied.

Starting from the conception that the ultimate aim of a state must be the conquest of the whole Empire, the Book speaks of the means of organizing the state for that purpose only. How can there be effected, in the first place, the centralization of power and the curtailment of the hampering privileges of the powerful families, the prevention of local fights and brigandage ? This is a fundamental point. It is therefore very much concerned with the prevention of any rise of influence in the hands of the subjects. The state and the people become two antagonistic factors. On the one hand the state should be made rich and strong, but on the other hand the utmost care should be taken for the people, as such, to remain weak and poor and entirely dependent on the state. Then only can they be of use to the state, then only can the army be strong, and its obedience assured. This is meant by the curious expressions which serve as the titles of two separate paragraphs : "Elimination of Strength" (353) and "Weakening the People" (354).

«If the people are stronger than the government, the state is weak; if the government is stronger than the people, the army is strong. 》 (355)

Rewards and punishments are the means by which this ${ }_{\text {p.83 }}$ dependence is effected. These two should control entirely the position of the people. They 
are only given for real merit or demerit, and there are only two kinds of employment which can give any claim to rewards, viz. agriculture and warfare. On these two the existence of the state depends, and as the people are naturally averse to being engaged in two such hard occupations, the judicious distribution of rewards and punishments should stimulate them in their pursuit. They should be constantly employed in either one of these ; and, as war is even more hateful to the people than agriculture, ordinary conditions should be made so hard for them, that they look upon war as a welcome release from their toil and as a good opportunity for earning rewards. Then they will fight with all their energy ; they will « gain ten points for every one that it undertakes » (356). The army should shrink from no dangers; if it dares to perform what the enemy dares not, it wins and the state will become strong (357). Even fearful people will be made brave by a right system of penalties and rewards (358). In order to prevent people from escaping their duties, all people should be registered (359).

It is essential that no rewards in the form of ranks, etc., should be acquired by any other means than by merit in these two fields. Only this gate to riches and honour should be "opened"; all other gates should be "closed", "debarred" (360). Thus rewards and punishments are "unified", or "m ade uniform", that is, given according to one standard only, and the people will have "uniformity of purpose", or will be p.84 "concentrated" on one thing only, i.e. agriculture and war (361). Care should be taken that rewards are given sparsely : "one reward against nine punishments" (362), and that punishments are made severe : "light offences should be regarded as serious" (363), for this will prevent the evil from developing. The very severity of the penalties will make rewards the more valued, and the lightness of rewards will make penalties even more terrifying (364). Prevention is better than cure : the people should be governed while they are in a state of order and one should not wait till they have come into a state of disorder (365). The deterrent effects of severe penalties will be such, that penalties become unnecessary, and thus 'by means of punishments punishments will be abolished"; on the other hand, mild punishments, which allow minor offences to escape unnoticed, will allow crime to develop and thus the frequent use of punishments will become necessary. This system of punishments "will bring about punishments" (366).

How is crime to be discovered? If virtuous men are employed in the government; the wicked people will easily deceive them. Therefore it is necessary that the wicked should govern the virtuous (367). Fear alone can keep the people from transgressing the law, and thus it is true that "virtue has its origin in punishments" (68).

This "virtue" is, however, not "goodness". It is merely obedience to the law, as fixed by the state. It has nothing to ${ }_{\mathrm{p} .85}$ do with morality. For, indeed, Shang-tzu is completely and consciously amoral. His great fear is that the people should become interested in the traditional virtues, and thereby set up other standards of conduct than those established by the law. In the most contemptuous terms he speaks of these other virtues. He describes them as 
'licence" or "lice", which I have rendered by "parasites". Different groups of these are mentioned. Probably the oldest list is : Care for old age, living on others (without employment), beauty, love, ambition, and virtuous conduct (369). Another group contains : the Odes and History, rites, music, filial piety, brotherly duty, virtue, moral culture (370); and yet another has : the Odes and History, rites and music, virtue and the cultivation thereof, benevolence and integrity, sophistry and intelligence (371). In the longest list of all, which is certainly of later date and where not less than sixteen characteristics are given, to those already enumerated in, the second group are added : sincerity and faith, chastity and integrity, benevolence and righteousness, criticism of the army, and being ashamed to fight (372). If the people cultivate these virtues, they become entirely useless for the state, "the ruler will have no one whom he can employ for defence or warfare" and, if a country is governed by means of these, "it will be dismembered as soon as an enemy approaches, and, even if no enemy approaches, it will be poor" (373). "When a country is in peril and the ruler in anxiety, it is of no avail for the settling of this danger for professional talkers to form battalions" (374), and it is these talkers, these itinerant scholars, who are interested in moral problems $p .86$ and distract the minds of the people from the one thing they should be interested in, that is in agriculture and warfare (375).

Single-minded concentration on these occupations preserves the people's natural simplicity, $p^{\prime} u$ (376). Simplicity and ignorance are the real virtues of the people: No education and no culture whatever should they have, and therefore they should be kept poor. On the one hand the poor should be encouraged to till the land so that they become rich, but on the other hand the rich should not be allowed to remain rich, so as to prevent them from becoming lazy and addicted to the "lice". If one understands "how to make the poor rich and the rich poor", one will become strong (377). Strength should be "produced" for the benefit of the state, but, in order to prevent the people from becoming strong in themselves, strength should also be "reduced", that is, the people should be employed in more warfare. A state which neglects to do this, carries on a suicidal policy, and brings the "poison" of cultural pursuits into its own territory; whereas a state which knows how to "reduce " its strength will be able to attack others and to carry the "poison" into the enemy's territory $(\underline{378})$.

The riches which accrue to the state, should be kept within the country and should be stored in the granaries. There should be no "outlets", through which the profit disappears (379). Shang-tzu goes so far as to say that import of products means strength, and export means weakness (380). He is opposed p.87 to the use of money. "Money kills grain ; and grain kills money », so all efforts must be directed towards the production of grain and not of money (381). Trade should be prohibited and merchants hampered as much as possible $(\underline{382})$.

The fact that the rules for rewards and punishments are perfectly clear and definite, will make it easy for the people to know how to behave. They 
themselves will be able to judge between guilt and innocence. "If ten hamlets $(\underline{383})$ are the unit for making judgments, there will be weakness; whereas when five hamlets are the unit for making judgments, there will be strength; if it is the family that gives judgments, there will be abundance » (384). And : «If the order of the country depends on the judgments of the family, it attains supremacy; if it depends on the judgments of the officials, it becomes only strong ; if it depends on the judgments of the prince, it becomes weak (385). » That is, the law should, so to speak, apply itself and not require the constant interference of the ruler (386). If the law is clear and simple, and rank and office are only given ${ }_{\text {p. } 88}$ according to merit, " the law will be eliminated by means of the law», that is, it will make itself superfluous (387).

So we find that, by concentration on war and agriculture, by implicit obedience to the law, and by the prohibition of all cultural pursuits, the government is absolute master ; it "unifies" and "consolidates" (388) the people, and the state will not only become powerful, but will attain supremacy, or, in other words, will establish its authority over the whole empire.

This is, in a few words, the teaching of the oldest part of the Book of Lord Shang. Its ideas are crude and formidable enough. Not often in the history of thought have such principles been enunciated with such terrible simplicity, grim force, and brutal one-sidedness. The mind which first conceived these ideas could only move along one track; it was bent upon the attainment of one ideal only, willingly and consciously did it sacrifice all else to this one aim, and there is something of the terrible grandeur of the forces of nature in the crude sentences, which in their endless repetitiousness are as crushing as sledge-hammers.

It will be noticed that the background of these ideas is Taoistic. At first glance nothing could be further removed from Taoistic ideals of non-activity and non-interference, than this philosophy of power and warfare. Yet punishments and laws are merely a means towards an end ; in ideal government they are no longer necessary, they are "eliminated"; and things will govern themselves. The strong anticultural tendency is also entirely in keeping with Taoistic tenets, and ${ }_{\text {p.89 }}$ the natural simplicity, $p^{\prime} u$, of the people, which should be preserved, is one of the key-words of Taoism.

The law, $f a$, in this system does not comprise much more than the rules for rewards and punishments. Therein it is still very close to the old idea of law, which was that of criminal law only. Whereas, however, this criminal law was only an aid to secure the maintenance of $l i$, the right conduct, prescribed by natural law, $f a$, this system of rewards and punishments, for merits and demerits towards the state, now replaces $l i$, and itself becomes the right standard of conduct. The two meanings, in which the word $f a$ is used, i.e. (1) model or standard, and (2) law, penal law, coalesce completely. The law of the state becomes the norm of conduct, and this law is divested of its moral character (389). Here is a complete breach between law and ethics. 
Yet, however crude this law might be, it is law. There is definiteness, equal application to all and publicity. These are indeed new principles. The nobles had so far been exempt from the application of penal law, according to the old rule, recorded in the $\mathrm{Li}$-chi (390), that « punishments do not extend up to the great officers ». They had been the class that were entirely governed by $l i$ in its strict sense, which did not reach down to the common people (391). The equality, now established, reminds one again of the strong hand of a statesman like Shang Yang, supposed to have abolished the privileges of the nobles.

With regard to the publicity and definiteness of the law, it should be noticed that this government, which despised ${ }_{\text {p.90 }}$ all moral virtue for the people, claims one virtue for itself, in which it expects everybody to believe : good faith (392), that is, in the bestowing of promised rewards and the application of punishments. It makes both public, that everyone may know. This is by no means a self-evident principle. It is reported that the code of laws which the old statesman, Tzu Ch'an, drew up, and which he had engraved on a sacrificial cauldron, was very unpopular, because it was thought, that the people would be more difficult to govern and become more quarrelsome, should they know the laws (393). Confucius himself is said to have criticized a similar action, as it would lower the respect and authority of the higher classes (394). Now this principle of publicity and invariability is recognized by the state to be in its own interest because of its deterrent effect. So, though the law may be arbitrarily fixed, once it has been published, it has to be enforced. There is, therefore, no room for the arbitrary conduct of the princes (395).

I am here supplementing the older and very defective paragraphs somewhat from other arts, which are in this respect, I believe, entirely in keeping with the original ideas. Now brief though the mode of expression may be, these certainly do not lack logic and system. They strike me as being the theoretical and one-sided elaboration of ideas, born of the practical necessities of the age. In political, economic, and ethical respects they seem to form a unity. The Han p.91 history says (396), that the doctrine of the School of Law originated with administrative officials, and I believe that is right. It may be repeated once more, that strong administrators such as Shang Yang is supposed to have been, in desiring to increase the power of the state, exercised through officials chosen for their merit, came into conflict with the established privileges of the noble classes. Further, the patricians lived on the land, insufficiently cultivated by the peasants, and they profited from the trade and arts, which enabled many of them to live in luxury in expensive establishments. For a statesman in an agricultural country like China, it was, in the first place, necessary to make a better use of the land and to increase the produce, and it may well be true that this was done by giving the land free to everybody, thus at the same time weakening the position of the noble classes (397). They were governed by $l i$, the code of etiquette and moral conduct, handed down from antiquity, and they carefully preserved these traditions. The law could scarcely touch them (398). So the political and 
economic necessity led to a violent opposition against all $l i$ or traditional standards of conduct, together with a rejection of trade and arts, that served cultural pursuits and strengthened the position of the patricians. Confucianists like Mencius had been constantly upholding the old order of things; their ideal was intensely aristocratic (399). One should ${ }_{\text {p.92 }}$ remember that Mencius defended the old ching system of agriculture, that he pleaded for free trade (400), and relied on the personal virtue, based on the old standards, of the noble classes and the ruler to govern a state well. Thus practical politicians, in this period, had to enter into conflict with the Confucian scholars and their ideal of culture and virtue.

It is impossible to say in how far these ideas in the oldest parts of Shang-tzu have any direct connection with Shang Yang. From the above it will, however, be clear that they are the natural outcome of the conditions of the time. In a less pronounced form Shang Yang, if he was at all what he is said to have been, must have acted along these lines. We know that he was successful ; we also know that a similar policy was later pursued by Ch'in ; there is therefore nothing improbable in the tradition, which calls him the initiator of this policy. This does, of course, not mean that he consciously professed the whole system, which I have outlined, with all its extravagances.

\section{Further Ideas of the Book of Lord Shang}

In discussing the ideas of the Book of Lord Shang in the previous paragraph, I have purposely confined myself to what seem to be the oldest elements in it. It should, however, not be supposed that the conceptions which I have explained are not found in other parts of the Book than those from which quotations were given. On the contrary ; the Book is full of repetitions ; many of these leading ideas are expressed over and over again. Especially the necessity of severe ${ }_{\text {p.93 }}$ punishments, of training for war and agriculture, of the limitation of rewards for merit (401) in these two spheres of activity is repeatedly urged in several other paragraphs, as well as the evil of cultural and moral pursuits. To give a summary of these utterances, which are sometimes very striking, would only lead us to the same repetitiousness from which the Book suffers, and is unnecessary here. We may refer to the text of the Book which follows in translation (402).

Apart from these ideas there are, however, several others in the Book, which certainly do not belong to the same system of thought, for, as we shall show in Chap. IV, the Book is far from being a unity. It is not always possible to draw a sharp line of demarcation; sometimes they are evidently a later development, which however fits in very well with the original scheme; sometimes they clash. They form part of the general current of thought which is designated as the School of Law and they find parallels in other authors. I shall therefore discuss them here together with these; sometimes this will lead 
us back again to the narrow system which we just studied, but more often it will show us the School of Law in a new light. The origin of some of these ideas lies certainly not with administrators ; they are the outcome of that interchange of thought between men of different views of which some instances have been given (403). With a man of Shang Yang's ${ }_{\text {p.94 }}$ type they have nothing to do at all, except that he may have given the great impetus to the idea of law.

This leads us first to the discussion of another keyword, which is found in the writings of some of the legalists, and also occurs, though sparsely, in the Book, viz. "methods", shu.

If we may believe Han Fei-tzu, who, it should be remembered, lived less than a century later in a country that had constant relations with Ch'in, it was very typical of Shang Yang that he attached so much importance especially to the idea of law. He contrasts in a section, that is generally admitted to be genuine (404), Shang Yang and Shen Pu-hai. The first, he says, knew only "law", the second only "political methods". The first, he explains, is "that laws and mandates are manifest in the official bureaux, that the people have the conviction that punishments are definite, that rewards are based on a careful observance of the law, and that punishments are inflicted on those who infringe the law : it gives guidance to the officials". And as to the second, political methods : 'to confer office according to responsibility ; to demand real service corresponding with the title carried, to sway authority over life and death, to test the capacity of the officials : it is that of which the ruler disposes".

Han Fei-tzu then proceeds to show that both "law" and "methods" are necessary :

«Shen Pu-hai was the aid of the Marquis Chao of Han, which was one of the states into which Chin had been divided. Now the old laws of Chin had not yet been repealed, when the new laws of Han appeared on top of these ; the orders of the former princes had not yet ${ }_{\text {p.95 }}$ come to the point where they were all carried out, when the new orders of the later princes were issued. As Shen Pu-hai did not take control over the laws, and did not unify the orders, crimes were many. For, whenever there was advantage in the old laws and the earlier orders, these were followed, and whenever there was advantage in the new laws and the later orders, these were followed. As old and new clashed with each other, and the earlier and later orders contradicted each other, though Shen Pu-hai might have caused the Marquis Chao ten times to use 'methods', yet the wicked ministers would have found opportunities to twist his words. Therefore, though it could rely on the strength of ten thousand chariots, Han's ill-success in not attaining, in the course of seventeen years, leadership or supremacy, was due to the fact that, although the ruler used 'methods', 'law' was not diligently observed by the officials. 
Kung-sun Yang in ruling Chin established the system, that denunciation of crime was obligatory, and that (for the non-denunciation) one was punished as if one had committed the crime oneself; he organized groups of ten and five and held them all responsible for each other's crimes. Rewards were made liberal and were faithfully carried out, punishments were made severe and definite, consequently the people applied their force and toiled without rest, pursued the enemy and did not shrink from dangers. Therefore his state became rich and the army strong. However, not having 'methods' whereby to discover crime, with his riches and strength he merely benefited other ministers.

Then, after having shown that Lord Shang's successors all to ok large benefits for themselves in all the victories which ${ }_{\text {p.96 }}$ they won, he ends by saying :

« Though the Lord of Shang had improved his laws ten times, the ministers used the benefits acquired for other ends, and by whichever crafty means he strengthened the resources of Ch'in, its ill-success in not attaining in the course of several decades, the emperorship, was due to the fact that, although the laws were diligently observed by the officials, the ruler above did not have method.

The character of these "political methods" is somewhat further defined in a passage in Yin Wen-tzu, which we shall discuss below in more detail. There it is said (405) that "methods" are something which the prince secretly uses, and in which the subjects should not be initiated. The "methods", which were used by the ancient emperors and kings, are mentioned as being: benevolence, righteousness, rites, music, terminology, laws, punishments, and rewards (406); so the term seems to indicate the totality of the ruler's political measures, by which he controls his officials.

In the sixth paragraph of the present Book of Lord Shang, mention is made of the necessity of the use of "methods", without, however, being much insisted upon (407).

There are some other technical terms in the Book which should be studied somewhat closer. Another word shu occurs, meaning number, which acquires the meaning of "statistics", or "statistical methods". Already in the oldes t parts of the Book there is a preference for expressing everything in numerical figures: "they will gain ten points p.97 for everyone that it undertakes" (408); "one reward to nine punishments" (ㅆ09), etc., and in paragraph 4 their importance is touched upon (410). With much more detail the necessity of statistics is explained in paragraph 6, where the importance is argued of making a proper land-survey and of establishing a due proportion between the number of inhabitants and the surface and quality of the land (411). As I have explained in Chapter II, these ideas are connected with those ascribed to $\mathrm{Li}$ K'uei, the Councillor of Marquis Wen of Wei (424-387). In paragraph 24 this 
idea appears again, but in a much wider and more developed sense, as may be expected in a paragraph which is evidently of later origin. Here it stands for the governmental system, which is based on calculation, one might almost say, the science of government. The text says :

« The early Kings did not rely on their belief but on their figures .... If, in measuring an abyss, you know that it is a thousand fathoms deep, it is owing to the figures which you find by dropping a string (412).

It is used in connection with another remarkable word, which it is extremely difficult to render satisfactorily in any translation. This is shih, "conditions, circumstances, influence, power." Ku an-tzu says :

«That whereby a ruler is ruler, is power (shih). (413)

In Han Fei-tzu we find an interesting utterance of Shen Tao on the necessity of shih, which explains its meaning. This passage (414) runs as follows :

«Shen-tzu said :

- A flying dragon rides on the clouds, and a floating snake travels on the mist ; but when the clouds ${ }_{\text {p. }}{ }_{98}$ disperse and the mist lifts, the dragon and the snake are not different from a cricket or an ant; that is, because then they have lost the element on which they rode. If men of talent are subjected by worthless men, it is because their authority is weak and their position low, whereas if the worthless can be subjected by men of talent, it is due to the authority of the latter being strong and their position honoured. Yao as an ordinary citizen was not able to govern three people, whereas Chieh as the Son of Heaven, was able to bring the whole empire into disorder. From this I know that circumstances (shih) and position should be relied on, and that talent and wisdom should not be respected. If, a bow being weak, an arrow is yet carried high, it is because it is speeded up by the wind; if, a person being of no worth, yet his orders carry, it is because they are assisted by the masses. When Yao was teaching his own dependents, the people did not listen; but when he was sitting with his face towards the south and was king over the empire, his orders carried, and his interdicts had force. From this I see that talent and wisdom are not sufficient to subdue the masses, but that circumstances and position are able to subject even men of talent.

I have used the word "circumstances" in my translation, but it is clear that "power" would really express better the sense of wh at is meant. Power, that is, which relies on the general condition and trend of things, as an abstract idea, and well distinguished from brute force. Han Fei-tzu, in discussing these ideas of Shen Tao, warns against the danger, that it is by no means certain that only men like Yao or Shun will obtain this power; in the hands of wicked p.99 individuals it will only make disorder worse, and, as there are more wicked 
than virtuous people, the chances are that there will be more often disorder than order in the world. In this power, these circumstances, this tendency, rightly understood, there is, according to Han Fei-tzu, something spontaneous, something which men have not in their power to establish, and which enables mediocre men to govern well.

The illustrations of shih used in paragraph 24 are similar to those given in Han Fei-tzu : a seed riding on the power of the wind, or eyesight being dependent on the circumstance, or the power of the sunlight (415). It is used for the "power" which enables a ch'i-lin to cover a thousand $l i$ a day (416), but also for the "tendency" towards order or disorder in a state (417). Government, it is here (par. 26) said, is only possible when there is this tendency towards order. Also :

« if conditions (shih) are such that one cannot commit crimes, then even a man like Chih will be trustworthy; but if conditions (shih) are such that it is possible to commit crimes; then even a man like Po I will be mistrustful (418).

Things, in other words, should be so organized, that there is order without actual interference from the ruler. This again is the Taoistic ideal, and the ruler will be enabled

« to repose on a rest-couch and listen to the sound of stringed and bamboo instruments, and yet the empire will enjoy order (419).

In the passage to which I have referred before, where he talks of "methods", Yin Wen -tzu also speaks of this shih. He treats it from his pronounced Taoistic and terminological ${ }_{\text {p.100 }}$ point of view. He says (420) :

«If the Way (Tao) is not sufficient to govern, methods $(s h u)$ are used, if methods are not sufficient to govern, the practice of weighing out things against each other is used (421), if this is not sufficient to govern, the trend of things (shih) is made use of. When these are made use of, one returns to a condition where things are weighed out against each other, when this happens, one returns to methods, by the use of methods one returns to law, and by the use of law one returns to the Way (Tao). By the use of Tao the Non-activity, $W u$-wei, will be realized and order will be established spontaneously.

Yin Wen-tzu then, after giving the definition of "methods" which I have quoted above, describes shih as 'the profitable instrument for the execution of statutes and laws" (422). No more, however, than the subjects should be initiated into the secret "methods" should they be allowed to use "the instrument" of power ( shih).

For Yin Wen-tzu, the best way to secure that the "methods" of a prince are kept secret and that nobody but he himself can dispose of the "power of circumstances" (shih), is to make terminology correct, so that all distinctions between things, rights and duties are clear. Only when names correspond 
exactly to the things which they denote, can laws be correct and order be established (423).

p.101 It is here that the theoretical speculations on the 'meaning of meaning", which were the fashion in the School of Terminologists (423a), connect up with the more practical side of the School of Law, which simply aimed at the formation of a powerful government. Here were the beginnings of the conception, that law was not merely valuable as an efficient means of government, but that it was an abstract principle valuable in itself. In the present Book of Lord Shang these ideas have also left their traces.

In paragraph 26 we meet ming in its technical sense of "hame, term, appellation, terminology" (424). In human relationships, it is often best rendered by "rights and duties" ; applied to questions of property, it acquires the meaning of "legal status", "legal title", and used in connection with the law, it means "heading or item of the law" (425). In the illustration of the story of the hare there is shown the importance of fixing the ming "legal title". So long as a hare runs wild, even sages like Yao and Shun will chase after it, because its legal title is not definite, but as soon as it is for sale on the market, not even a thief will think of taking it away, because its legal title is definite. So

« if everybody's rights and duties (ming) are definite, the very crafty will become faithful and trustworthy, and the people will all become honest and guileless, each one restraining himself. For indeed, the defining of everybody's rights and duties is the road that leads to orderly government, but the not defining of everybody's rights and duties is the road that leads to disorder (426).

p.102 The paragraphs 7 and 14, although they do not use the word ming, express more or less the same idea, where they speak of making divisions (fen) clear (427).

The question arises : how, by whom, and why have these divisions been established?

«The early kings hung up scales with standard weights, and fixed the length of feet and inches, and to the present day these are followed as models, because their divisions are clear (427a).

The word, here rendered in its original sense of "model", is $f a$, the law. It is clear that here it acquires an entirely different background. From being the arbitrary, but published, will of the ruler, it becomes the almost transcendental legacy of the past. No longer is the ruler himself the source of authority. Law becomes the model, fixed by the Sages, in the beginning of things.

What do we know about these beginnings? The seventh paragraph of the Book describes the origin of civilization : from a condition of matriarchate the sense of property developed; this led to a condition of mutual strife, which was restricted by the development of moral virtues. As, however, people became more numerous, there was not sufficient restraint placed on 
emulation, called forth by the importance attached to ability ; so a sage made divisions of land and property, men and women, and in order to maintain these divisions he set up interdicts, officials to enforce them, and a prince to unify the officials. Thus honour and rank began to be prized.

Paragraph 23 gives another retrospective view :

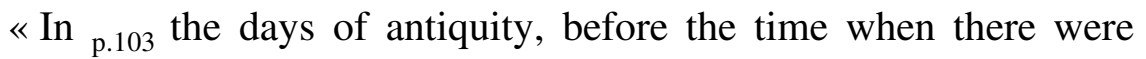
princes and ministers, superiors and inferiors, the people were disorderly and were not well administered, and so the sages made a division between the noble and the humble ; they regulated tank and position, and established names and appellations in order to distinguish the ideas of prince and minister, of superior and inferior. As the territory was extensive, the people numerous, and all things many, they made a division of five kinds of officials and maintained it. As the people were numerous, wickedness and depravity originated, so they established laws and regulations, and created weights and measures, in order to prohibit them, and in consequence there were the idea of prince and minister, the distinctions between the five kinds of officials and the interdicts of the laws and regulations, to which it was necessary to pay heed (428).

It is interesting to compare these theories of the origin of society with

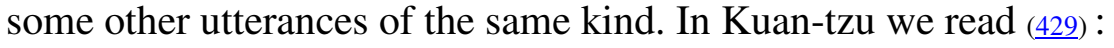

«In antiquity, before there was a distinction between prince and minister, superiors and inferiors, and before there was the union of husband and wife, consort and mate, people dwelled like beasts and lived in herds, and attacked each other by means of force. Hereupon the clever deceived the stupid, the strong oppressed the weak, and there was no room for old and young, orphaned and lonely people. Therefore clever men made use of the collective force of the masses in order to prohibit oppression, and the result was that the violent people were stopped; for the people's benefit p.104 they promoted what was profitable and removed what was harmful ; they regulated the people's idea of virtue and the people took them as their masters .... When superiors and inferiors had been established, the people formed an organization, and the state was founded.

So here there is a bellum omnium in omnes before the organization of society, and as in the system of the English philosopher who coined that phrase, morality begins only at the creation of the state. The first of the quotations from Shang-tzu which I gave, recognizes some restraining influence in that early stage exercised by morality (430), which, however, was not sufficient as people increased. In Han Fei-tzu the cause of strife is specially sought in the fact that people became more numerous, and, in deference to Taoism, an ideal period is supposed to have existed in the 
halcyon days, when people were still few and there was no struggle for life. We read, in paragraph 49 (431) :

« The men of old did not till the field, but the fruits of plants and trees were sufficient for food. Nor did the women weave, for the furs of birds and animals were enough for clothing. Without working there was enough to live, there were few people and plenty of supplies, and therefore the people did not quarrel. So neither large rewards nor heavy punishments were used, but the people governed themselves. But nowadays people do not consider a family of five children as large, and, each child having again five children, before the death of the grandfather there may be twenty-five grand-children. The result p.105 is that there are many people and few supplies, that one has to work hard for a meagre return. So the people fall to quarrelling and though rewards may be doubled and punishments heaped up, one does not get away from disorder.

In this view of historical materialism Han Fei-tzu differs from other schools. Mo Ti finds the necessity for the establishing of authorities in the different ideas which people held and which caused moral and intellectual confusion.

«Of old, when people were first produced, before there were penalties or government, the speech of men had (for each) a different meaning (432); for one man it had one meaning, for two men it had two meanings, and for ten men it had ten meanings. As the number of people became great, the meanings, which the speech uttered by them had, became also great in number. Thus people regarded each his own meaning as right and other people's meanings as wrong, and therefore in their intercourse they criticized each other. Consequently at home fathers and sons, elder and younger brothers, became angry with each other, were estranged from each other and could not live in harmony, and the people in the world harmed each other like water and fire or poison .... The disorder in the world was like that of birds or beasts. An examination of this disorder in the world showed that it came from not having government-leaders. Therefore the most capable man in the world was chosen and set up as Son of Heaven .... Only the Son of Heaven was able to unify all the meanings in the world, so that the world enjoyed order (433).

Of the Confucian School it is Hsün-tzu who has given most ${ }_{\text {p.106 }}$ thought to the origin of human society. He seeks the causes of human discord, as may be expected, in the moral sphere.

«Man by birth has desire. When desire is not satisfied, then he cannot be without a seeking for satisfaction. When this seeking for satisfaction is without measure or limit, then there cannot but be 
contention. When there is contention, there will be disorder; when there is disorder, there will be poverty. The former kings hated this confusion; hence they established the rules of proper conduct (li) and justice $(i)$ in order to set limits to this confusion, to educate and nourish men's desires, to give opportunity for this seeking for satisfaction, in order that desire should never be exhausted by things, nor should things be curbed by desire; that these two should support each other and develop. This is whence the rules of proper conduct $(l i)$ arise (434).

He regards it as characteristic of man only, that he is able to build a society. This is due to a moral quality, the sense of rights and duties (435), which he alone possesses.

«Water and fire have essences, but not life ; herbs and trees have life, but no knowledge; birds and beasts have knowledge, but no moral sense. Man has an essence, life, knowledge, and in addition has moral sense; hence he is the highest being on earth. His strength is not equal to that of the bull, ${ }_{\mathrm{p} .107}$ his running is not equal to that of the horse ; yet the bull and horse are used by him. How is that ? Men are able to form social organizations, the former are not able to form social organizations. How is it that men are able to form social organizations? Because of their distinctions. How is it that distinctions can be carried out? Because of moral sense. Therefore, having moral sense in making their distinctions, they live in harmony ; living in harmony, they are united ; being united, they have much strength; having much strength, they are powerful ; being powerful, they are the masters of all things (36).

So human society, for Hsün-tzu, is formed on a basis of the moral sense for what is right, and regulated by $l i$. He admits the law as a necessary complement, but maintains a natural ethical norm (437).

To return now to the School of Law, it is of the utmost importance that laws and regulations, weights and measures, which were established in order to restrain people, should be preserved. One ought not to turn one's back on these standards and try to judge for oneself, any more than a merchant would try to do without scales in weighing things.

« Only a Yao would be able to judge knowledge and ability, worth or unworth without a model, but the world does not exist exclusively of Yaos (438)!

This is a very central point in the teaching of the School of Law. Even supposing that a sage is able to act rightly under all circumstances, the average man, and even the average ruler, is certainly not a sage.

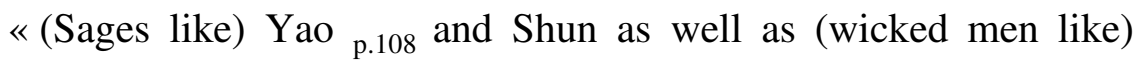
Chieh and Chou appear only once in a thousand generations (439). 
One should therefore not depend on the very rare presence of a sage for having good government, but one should rely on such measures and conditions, that even mediocre people can achieve good results. A passage from Han Fei-tzu illustrates this very clearly (440).

«I do not think it right to say (441) that good horses and a solid carriage, driven by slaves, will be the ridicule of people, but, driven by Wang Liang (442), will cover a thousand $l i$ a day. For example, if you wait for a man from Yueh, who is good at swimming in the sea, to rescue a drowning man in the Middle Kingdom - the man from Yueh may be a good swimmer but the drowning person will not be saved. In the same way, if you wait for Wang Liang of old to drive the horses of to-day, it will be the same story as that of the man from Yueh who would rescue that drowning person; it is also clear that it is impossible. But if good horses and a solid carriage are placed in readiness in relays of fifty $l i$, and you make a mediocre coachman drive them, it will be possible to get them to drive fast and far, and you will cover a distance of a thousand $l i$ in a few days. Why should one then wait for a Wang Liang of old?

Fortuitous results, which may happen occasionally in defiance of all law, have no lasting value, and do not prove that law and rule are unnecessary.

«If you sharpen an arrow and shoot it off blindly, its point may occasionally hit an ${ }_{\text {p.109 }}$ autumn hair (443), but one cannot therefore be said to be a good shot, as there is no constant rule (that this will happen). If one sets up a mark of five inches and shoots at a distance of ten paces, unless one is a (shot like) I or P'eng Meng (444), it is not certain that one will hit it; that is the constant rule. Therefore, if there is a constant rule, the fact that an I or a P'eng Meng hits a mark of five inches is accounted an achievement, but, if there is no fixed rule, the fact that a blind shot hits an autumn hair is accounted clumsiness (445).

A right system is therefore more reliable than chance-success or the presence of a specially gifted man. And even the latter, how does he obtain his success : by his personality or by his methods ? In Kuan-tzu it is said :

« Though one may have a clever eye and a practised hand, one cannot draw a square or a circle so well as clumsy compasses and a square may do it. So a clever man is able to make a pair of compasses and a square, but he cannot, while disregarding these, correctly draw a circle or a square. Even a Sage, though he may make laws, cannot, while disregarding the laws, govern a state (446).

There has been preserved, in Yin Wen-tzu (447), a vivid little conversation between P'eng Meng, his student T'ien P'ien, p.110 and Sung Hsing (448), all scholars of the Academy, at the gate of Chi, of which the beginning is interesting in this connection. 
« T’ien -tzu sat reading the Shu-ching and said:

— The period of Yao was one of great peace!

Sung-tzu said :

- Was this due to the administration of the Sage ?

P'eng Meng, who stood at one side, b reaking (449) in, replied :

- This was due to the administration of a sage law, not to that of a sage man.

This reply is very typical of the Law School. Confucius had still held the old belief in the supernatural influence of the king over the world — his virtue would be able to transform all without exception (450).

- He who governs by means of his virtue is like the North Pole Star, which keeps its position while all the other stars turn towards it (451).

Mencius no longer believed in this supernatural influence, but for him, the principles of jen and $i$, altruistic virtue and the sense of moral duties, which were practised by the Sages, were able to transform mankind (452). He held the optimistic belief that all men were susceptible to moral influence :

«All men may become a Yao or a Shun (453).

The secret of good government lay, apart from certain economical considerations to ensure the people's livelihood (454), entirely within the ethical sphere : morality had to be cultivated. Even Hsan-tzu, although he was pessimistic about human nature, expected everything ${ }_{\mathrm{p} .111}$ from moral culture, which could be effected with, the aid of the $l i$, the rules for right conduct, and law alone had no charm for him.

« The law cannot exist by itself .... The superior man is the source of the law. Therefore, if there is a superior man, though the laws may be sparse, they will be sufficient to embrace everything. If, however, there is no superior man, then, though the laws may be complete, one will fail in the right application of earlier and later things, it will be impossible to meet the changes of the times, and there will be reason enough for disorder (455).

The School of Law is very pessimistic in this respect. Morality, it says, cannot be taught.

«The benevolent (456) may be benevolent towards others, but he cannot cause others to be benevolent; the righteous may love others, but he cannot cause others to love. From this I know that benevolence and righteousness are not sufficient for governing the empire. A sage has a nature that insists on good faith, and he also has a law, by which he compels the whole empire to have good faith (457). 
«Li Chu saw an autumn hair at a distance of more than 100 paces, but he could not transfer his sharp vision to others; Wu Huo was able to lift a weight of 1,000 chün, but he could not transfer his great strength to others. And, indeed, sages cannot transfer to others the personality and nature that are inherent in them (458).

Thus the School of Law rejects all confidence in the fortuitous success, which may occasionally be obtained by special men and it regards all hope of good government by p.112 $_{\text {mol }}$ megeneration as futile. It aims at government by average rulers over people, who are inclined to do evil. Therefore it needs more than merely the restraining and guiding influence of $l i$, the rules of good behaviour, which presuppose the moral example of the ruler; but it needs the law with its compelling power. Thus one will be independent of the quality of the ruler and be able to cope with the refractory nature of the people.

«Generally a ruler of men does not, in virtuous conduct, exceed other men, nor does he do so in knowledge, nor does he surpass others in courage and strength; yet the people, though they may have sages and wise men, dare not plot against him ; though they may have courage, dare not kill him ; though they are numerous, dare not overrule their lord; though the people may reach a number of many tens of thousands, if heavy rewards are set before them, they dare not contest for them ; if, penalties are applied, they dare not resent them. The reason is that there is law (459).

So the law is not concerned with the virtuous few, who may practise virtue for virtue's sake :

«Seek-transgressors and do not seek the virtuous (460).

«The system of good government is to neglect the virtuous and to abolish the wise (461).

It is only interested in the wicked, who form the majority, and who need to be compelled into the paths leading to good results. Exceptions do not interest a ruler :

«There may be one case in ten millions, where the directing guidance of the law is not needed, and yet it is correct in every thing. Therefore, the ${ }_{\text {p.113 }}$ Sage governs the Empire for the ten million cases (462).

«If we should use arrows, which are straight of themselves, there would not be an arrow in a hundred years ; if we should only use pieces of wood, which are round of themselves, in a thousand years there would not be a wheel. In a hundred years there is not one arrow that is straight of itself, nor a wheel that is round of itself, how is it then that every one in the world drives in carriages and shoots birds ? It is the result of applying the art of stretching and curbing (463). 
The natural consequence is to make the law severe.

«In strictly managed households, fierce rebels will not appear, but a compassionate mother has spoilt sons; from this I know that by severity violence may be prevented, but that virtue and kindness are not effective in causing disorder to cease (464),

says Han Fei-tzu. Here these portions of the Book of Lord Shang connect up with the older parts :

«Therefore if you govern by punishments, the people will fear; being fearful, they will not commit villainies; there being no villainies, people will be happy in what they enjoy. If, however, you teach people by righteousness, they will be lax ; if they are lax, there will be disorder; if there is disorder, the people will suffer from what they dislike (465).

Han Fei-tzu expresses himself very strongly on this point.

«Now take a boy who is a bad character. His parents may get angry with him, he does not change. His neighbours may reprove him, it does not have any effect on him. His ${ }_{\text {p.114 }}$ masters may moralize to him, he does not reform. All the excellent devices of which love of parents, conduct of neighbours, and wisdom of teachers may dispose, are applied to him, but they remain totally without avail, and not a hair on his shins will change. But when the district official sends his soldiers and in the name of the law searches for wicked individuals, then he becomes afraid, changes his principles, and reforms his conduct. So the love of parents is not sufficient to teach a son morality, but the severe punishments of the officials are needed. People become naturally spoiled by love, but obedient to severity (466).

Or again :

« The love of a mother for her son, is twice as great as that of a father, but for getting orders obeyed by a son, a father is worth ten mothers. The officials have no love for the people, but for getting their orders obeyed by the people they are worth ten thousand fathers and mothers. A father and mother accumulate their love and yet their orders are fruitless ; officials apply severity and the people obey their orders (467).

The law thus being the means to combat wickedness, all private standards of morality become objectionable, as they necessarily must differ from the one standard set up by the state. Here lies the conflict between law and ethics. We have seen before (468) how this belongs to the old stock of ideas in the Book of Lord Shang. Nowhere is this antagonism more clearly expressed than in Han Fei-tzu, where the argument is particularly directed against the Confucian conception of morality. 
«p.115 In the state of Ch'u there was a certain upright man, who, when his father had stolen a sheep, denounced him to the official. But the Prime Minister condemned him to death, judging that he had acted in an upright manner towards his prince, but crookedly towards his father, and that in return, therefore, he should be punished. Looking at it from this point of view, the subject that is upright towards a prince is a wicked son to his father (469).

«There was a man of Lu, who followed his prince to the war and who in three battles ran away thrice. When Chung-ni (Confucius) asked him the reason for that, he replied :

- I have an old father, and when I die there is nobody to take care of him.

Chung-ni regarded this as an act of filial piety, brought him to the fore and presented him to the prince. Looking at it from this point of view, a father's filial son as a subject turns his back on the prince (470).

Here is the most complete clash between civic duties and personal morality. For the School of Law there can be no doubt which of these should have precedence.

Such complete rupture with traditional ethical concepts shows a different attitude towards the past. And indeed, though it is frequently stated that the Sages of old-instituted the "weights and measures, statutes and laws", which

should ${ }_{\text {p.116 }}$ be followed, yet it is one of the marked characteristics of this School that it refuses to be bound by traditional laws. Again and again it is repeated that laws should fit the times, and that different periods require different laws. The argument in the great discussion in the first paragraph turns on this point, and the Book never tires of showing that in antiquity not always the same laws and customs have prevailed. So for example at the beginning of paragraph 18 (471) :

«Of old, in the times of the Great and Illustrious Ruler, people found their livelihood by cutting trees and slaying animals; the population was sparse and trees and animals numerous. In the times of Huang-ti, neither young animals nor eggs were taken. . . These measures were not the same, but that they both attained supremacy was due to the fact that the times in which they lived were different. In the times of Shen-nung, men ploughed to obtain food and women wove to obtain clothing. Without the application of punishments or governmental measures, order prevailed, without the raising of mailed soldiers, he reigned supreme. After Shen-nung had died, the weak were conquered by force and the few oppressed by the many. Therefore Huang-ti created the ideas of prince and minister, of superior and inferior, the rites between 
father and son, between elder and younger brother, the union between husband and wife and between consort and mate. At home, he applied sword and saw and abroad he used mailed soldiers; this was because the times had changed. Looking at it from this point of view, Shen nung is not higher than Huang-ti, but the reason that his name was honoured was because he suited his time.

p.117 In another place (472) is shown that in Shen-nung's time people were ignorant and therefore he obtained the leadership by means of his knowledge ; in the times of Ch'eng T'ang and $\mathrm{Wu}$-wang, however, when people were clever, these could only succeed by means of force. It would be unwise, when the times are like those of T'ang and $\mathrm{Wu}$, to follow the methods of Shen-nung.

«Laws, which are established without examining people's conditions, do not succeed, but a government which is enacted fittingly for the times, does not offend (473).

In the excellent $49^{\text {th }}$ paragraph of Han Fei-tzu this idea is explained at length and is illustrated by an amusing little anecdote (474) :

«There was a man of Sung (475) who tilled his field. Now in his field stood the stem of a tree, and once a hare in full course rushed against that stem, broke its neck and died. Thereupon the man left his plough and stood waiting at that tree in the hope that he would catch another hare. But he never caught another hare and he was ridiculed by the people of Sung. If, however, you want to rule the people of to-day with the methods of government of the early kings you do exactly the same thing as that man who waited by his tree.

It was in itself not a new idea that laws, rites and customs were subject to change - Mo Ti especially had shown with great force the relative values of all customs.

«Formerly there was east of Yueh the country of Chen-mu (476). When there an eldest son was born, he was cut into pieces and eaten up, and it was said that this benefited the younger brothers. If a grandfather died, the grandmother was carried off on the back and left, ${ }_{\text {p.118 }}$ for it was said that one could not live together with the wife of a ghost. ... South of Ch'u was the country of the Yen people. If their relations died, they let the flesh rot and threw it away, and then they buried the bones, thus fulfilling the duties of a filial son. West of Ch'in was the country of I-ch'ü. If there a relation died, fuel was piled up and he was cremated; when the smoke rose up, it was said that he ascended afar, and after this, one had fulfilled the duties of a filial son ... (477)

Now for Mo Ti the authority of the. past and the tradition of the Sages had not the same value as for the Confucianists. For him rites in themselves were not so important, as they were with these latter. He was interested in the 
meaning of the rites, he regarded things from a personal, not from a social point of view, and the will of Heaven was his ultimate guide for action. Within the Confucian School, however, it was now also admitted that rites were liable to change. Hsün-tzu was so much a child of his time that he no longer believed in the harmony between natural and moral law. For him, human nature being bad, all moral standards set up to guide it, being essentially created by men, were "artefact" (478). Moral authority was external. But he exercised his own discrimination in choosing his authorities; instead of the former Sages, he preferred the later Sages, who, as he said, were better known.

Hsün-tzu did not admit in so many words, that the teaching of the later Sages was better fitted for the age, but he had certainly been influenced by the frankly utilitarian point of ${ }_{\text {p.119 }}$ view of the School of Law. This asked only what was practical, and in spite of the great importance it attached to stability of the law and its ultimate foundation in antiquity, it defended the right of every ruler to alter the law so as to meet the needs of his own time. Here lay, as we have seen, its very origin. This is, of course, in direct antagonism with the Confucian idea that only a Sage could make laws.

It is, however, essential that once the law has been fixed, it should not be altered arbitrarily by the ruler to suit his own taste. Rewards and punishments should be promptly given only to those who really deserved them, and appointments only to men of merit. This is again connected with the conception of the Terminologists, that names and things should correspond to each other. On no account should the ruler in his decision be influenced by presents (479).

«The early Kings in governing the state, let the law select people, and did not choose themselves; they let the law weigh merit, and did not measure it themselves (480).

And again :

«An intelligent ruler does not reward those who have no merit, though he loves them; he does not punish those who have no guilt, though he hates them (481).

«An intelligent prince knows that the people think of the ruler (as an example); therefore he establishes laws to govern himself, he fixes modes to correct himself (482).

And, as it is said in the Book :

«The one who gains the empire is he who regards it as his first duty to gain himself; the one who ${ }_{\text {p. } 120}$ succeeds in conquering a strong enemy is he who regards it as his first duty to conquer himself (년).

«An intelligent ruler is cautious with regard to laws and regulations; he does not hearken to words which are not in 
accordance with the law; he does not exalt actions which are not in accordance with the law; he does not perform deeds which are not in accordance with the law (484).

The philosophers of the School of Law knew very well that it is one thing to have laws and another to secure their application, and, as we have seen, much of their effort is spent on this problem. They did not tire of seeking an answer to Hsün-tzu's taunt, that

«there has been bad government under good laws, but from ancient times to the present there has never been known to be bad government under a superior man (485).

Is there really no remedy to the situation that

«all states have laws, but there are no laws that guarantee that the laws are practised ? (486)

Strict rules for rewards and punishments, "system", "method", "conditions", all these serve as auxiliaries to the authority of the law. Now how should this be put into practice in the organization of the country?

An important principle was discovered: that of mutual control. If the reports about Shang Yang deserve confidence, he had instituted the system of mutual control even for the people (487) by organizing them into small groups, the members of which were responsible for one another. Thus the right p.121 "conditions" were created

« in which even a man like Chih does no wrong (488).

The secret of this system is that people's interests are made different, for man's interest is his guiding motive.

«The people's attitude towards profit is just like the tendency of water to flow downwards, without preference for any of the four sides. The people are only interested in obtaining profit and it depends on what their superiors encourage, what they will do (489).

«In a condition of complete good government, husband and wife and friends cannot abandon each other's evil, cover up wrong-doing and not cause harm to relatives, nor can the men from the people mutually conceal each other from their superiors and government servants. That is because, although their affairs are connected, their interests are different (490).

Truly an opposite state of affairs from that commended by Confucius ! Now this same system should be applied to the whole official organization. It is not sufficient to appoint "assistants and controllers" who are to prevent the officials from making profit, because these "assistants and controllers" themselves desire to make profit (491) :

«their affairs are the same and they belong to one body. Now those whose affairs are the same and who belong to one body, 
cannot control one another. But by making their interests different and the disadvantages dissimilar, the early Kings created guarantees (492).

« The early Kings made it a principle that those, whose business was connected, should have different interests (493).

The development of this idea of making the interests of the officials different, in order better to guarantee the application ${ }_{\mathrm{p} .122}$ of the law, leads to a division of the officials' competencies. It is not yet the 'trias politica" which is discovered, but, if I may so call it, a "duas politica". A very remarkable system is set forth in the last paragraph of the Book, making a clear distinction between executive officials and "law -officials", that is, officials whose task it is to maintain the law.

This paragraph shows a very real advance in the ideas of the Law School in more than one respect. It is concerned with the fixing of rights and duties, with the terminology, which we have discussed before, and therefore speaks of law in its wider aspect. It realizes its almost divine origin and it recognizes the transmitted laws and terminology of the ancients as authoritative.

«Should they not be accepted as authoritative and should people discuss them according to ideas of their own mind, then until their death they will not succeed in understanding the terminology and its meaning (494).

These laws have been handed down in writing and special law-officials should study them. The law-officials have been set up by the Sages and

«should be authoritative in the Empire, in order to define everybody's rights and duties, so that these being definite, the very crafty would become faithful and trustworthy, and the people would all become honest and guileless, each one restraining himself (495).

It is no longer the ruler himself, who is identified with the maintenance of the law, nor is it a dead book or a tradition, but there are living interpreters of the ancient writ, who, moreover, are in close touch with the every-day practice of government. For they have to interpret the laws to the people and to the officials and have to give their opinion, whenever it is desired, ${ }^{123}$ about the legality or otherwise of administrative actions or people's conduct (496). Their interpretations of the law are put on record and "on the death of the officer, affairs should be transacted according to these files (497)." So there is continuity and progression in legislature, there is real jurisprudence. Careful regulations are made for the preservation in archives of all the laws, and heavy punishments are fixed for illegal alterations made in the text of the law. Special students are set to study the contents of the law, so that at the death of law-officials there are always competent men for law-interpretation (498). The result of this system will be that 
« there shall be no one among the government officials and people of the Empire, who does not know the law, and as the officials are clearly aware that the people know the laws and mandates, they dare not treat the people contrary to the law, nor dare the people transgress the law, as they would come into conflict with the law-officers (499).

The law will then be understood by everybody, stupid and wise alike, and the people will be

«prevented from falling into dangerous pitfalls.

«So the fact that when the Sages established the Empire, there were no victims of capital punishment, was not because capital punishment did not exist, but because the laws, which were applied, were clear and easy to understand ... They knew that if the ten thousands of people all knew what to avoid and what to strive for, they would avoid misfortune and strive for happiness, and so restrain themselves (500).

From the crude ideas of the older part of the Book to these conceptions is a great step. It is very doubtful whether such ${ }_{\text {p.124 }}$ a scheme as here propounded has ever had practical application; it is possible, however, that the institution of the censorate, which is not unlike that of the law-officers - with the difference, that it is the rites, rather than the law, which they are called upon to uphold - owes some of its features to the ideas here emitted for the first time (501).

\section{Influence of the School of Law}

We have seen how the School of Law developed under the stress of the struggle for existence of the contending states. The law, which it proclaimed, was one which destroyed the privileges of feudalism, aimed at centralization and created power for the state. It was anti-cultural and anti-moral, because it was on traditional culture and morality that the position of the noble classes was based and from which they took their standards of conduct. This conception of law was enriched by the more truly philosophical tendencies of the age, which insisted that name and reality should correspond, that rights and duties should be defined, and it received more depth from the Taoist conception of governing without actual interference. Just as the Confucianists claimed for $l i$ the authority of antiquity, so did the jurists gradually for their principle of law, at the same time, however, maintaining that different conditions demanded different laws.

They had the unusual chance that for a time their main principles were adopted by the state of Chin. By strong centralization, efficient military organization, land-reform, replacement of feudalism by a well-disciplined 
bureaucracy, p.125 and a far-sighted policy, did it succeed in conquering the whole Empire. In a cultural respect Ch'in was a backward country, more than half "barbarian" in origin. Hsün -tzu, who had travelled there, on being asked what he had seen, said that the people were simple, that there was little music, that clothing was not very refined, and that the officials were feared, and that it was regrettable that there were practically no scholars (502). Elsewhere he says that the people of Chin are wanting in the observance of the right conduct between father and son, husband and wife, because they are remiss in observing the rules of proper conduct (li) and righteousness $(i)$ (503).

That in such a country an anti-cultural doctrine easily prevailed is not surprising. We have seen how in the Book of Lord Shang different "lice" are enumerated, and it is of particular interest to notice in this list the Odes and the History, those two pets of the Confucian school. A tradition, recorded in Han Fei-tzu (504), says, that the Lord of Shang taught Duke Hsiao "to burn the Odes and History". Too much reliance cannot of course be placed on this tradition, but we may assume as certain that a strong opposition to the study of these books existed in the circles influenced by the Law School. Han Fei-tzu is very explicit on this point. In one of his most important chapters he says $(\underline{505})$ :

«Therefore in a state of an intelligent ruler, there is no literature of books and bamboo tablets, but the law is the only doctrine ; there p. 126 are no sayings of former Kings, but the officials are the only models.

Now this becomes of enthralling interest, when we remember that the First Emperor, Ch'in Shih-huang-ti, read and appreciated the chapter in which such words occur. For Ssu-ma Ch'ien records that, upon reading the sections $K u$ fen and $\mathrm{Wu}$-tu (106) (which is that just mentioned), Shihhuang exclaimed :

- Oh, could I only meet this man; with him I could even go to death without regret ! (507)

This leaves no doubt but that it was the anti-cultural teaching of the School of Law, which had prepared the mind of Chin Shih-huang-ti for the deed by which he incurred the hatred of all later generations: the Burning of the Books in 213. Li Ssu, in advising him to this action, merely put into practice what the Law School had been teaching for decades, and he found a willing ear in his master, who, no less than the mighty Corsican to whom he is often compared, detested "tous ces idéologues".

The doom of the Law School was sealed with the fall of the short-lived Ch'in dynasty, with which it had been so closely affiliated. This did not mean that its influence came to an end. For the institutions of the Ch'in dynasty, formed by the Law School, profoundly influenced those of the Han.

Right at the beginning we read that Hsiao Ho, the great Councillor of Liu Pang, who became the first Emperor of the Han dynasty, as soon as he had occupied the capital of the Chin, took special care to preserve the maps and 
laws (508). We know, too, that he was particularly interested ${ }_{\text {p.127 }}$ in the Fa-ching, in 6 sections, which had been composed by the same Li K'uei, the Minister of the Marquis Wen of the state of Wei (424-387), whom we have already met in connection with his economic calculations (509). To this law, the oldest Chinese law of which the memory has been transmitted, and which evidently formed part. of the code of the Chin, he added three sections, called Shih-lü.. Minister Shu-sun T'ung, who had also drawn up a Court ceremonial for the first Han Emperor (510), added 18 sections to this. Finally 27 sections from the Yüeh-kung-lü, by Chang T'ang, Minister of Justice, who was notorious for his severity (511), and 6 sections from the Ch'ao-lü, by Chao Yü, another statesman of the time of Wu-ti, were added to all this about the year 119 B.C., and this collection of 60 sections together formed the Han-lü, the Code of the Han dynasty. In the second century A.D. Ma Jung and Cheng Hsüan (512) wrote their commentaries on this code (513). It was unfortunately lost before the sixth century. In view, however, of the strong sense of tradition which the Chinese have always shown in their institutions, it is not unreasonable to suppose, that through indirect channels, part of it found its way into the codes of following dynasties. In any case it helped to form the mind of the Chinese in judicial matters.

p.128 So the Han dynasty owed much to the work of the Law School. But it was natural, that after the radicalism of the Ch'in d ynasty, a period of reaction should set in. The Han dynasty profited by the abolition of the feudal system, carried through by Ch'in's energy, but once its power was firmly established, the great stress was gone in which the Warring States had continually lived. Liu Pang's saying, that on horse back he had conquered the Empire, and on horseback he proposed to hold it, proved false. More was needed than brute strength. The aim had been reached, the world was united under one sway; the ideals set by the Law School had outlived themselves. Once more there was room for the activities of the scholars who were interested in cultural and moral life. The Confucian tradition of the identity of natural and moral law, in which the person of the Son of Heaven played so great a part, acquired a new significance. Strengthened by the radical reforms which Chin had effected, the Han saw in the Confucian doctrine a powerful means for placing the authority of the Emperor on a strong moral basis, without immediately running the dangers which had ruined the Chou house. Encouragement was soon given to the rediscovery of the ancient books, and that movement began, which has for ever marked Chinese civilization with the stamp of antiquity, and has enthroned the Confucian tradition as the authority for all ages..

Thus, while profiting from its work, China has rejected the doctrines of the Law School. The gulf between law and ethics, created by the Law School, was bridged by again restricting law to merely penal law, containing sanctions on the observance of the recognized rites and customs. Law became again firmly p.129 embedded in ethics; it never acquired authority as an independently regulating norm of conduct. Down to the most modern times measures in imperial mandates were justified by invoking the natural moral law; the 
standard of conduct was $l i$, not $f a$, the state-law. The crude attempts of the School of Law to regulate life by man-made law has scared the Chinese mind away from attempts in that direction, even from codification of the existing customary law, from any other point of view than that of the penal. The Jurists wanted to make law, without any touch with the people's sense of right and wrong, into a dead mechanism, which worked automatically like a compass or a pair of scales. They ruled out entirely the source of law, which lies in the development of life itself. Hsün-tzu has very well drawn attention to this mistake. He says :

«If there are laws, but they are not discussed, then those cases, for which the law does not provide, will certainly be treated wrongly (514).

Law can never be complete and should be supplemented by the standards which live in the people. This last truth, so long forgotten in the western conception of law, when the Juristenrecht prevailed, has always been alive in China : It has led to the other extreme of making law but a reflex of natural, customary law, without any regularizing force of its own. It is not understood that a thing may be right or wrong, merely because it is allowed or forbidden by the government; everything is judged according to the intrinsic moral value which it has, measured by the supposedly-known natural law.

p.130 Government measures are therefore obeyed, in so far as they correspond with this popular sense of rightness, not merely because it is positive law. Therefore innovations, which are not consecrated by custom, are ignored. This is one of the great problems which modern China has to face. In a modern state, with highly complicated economical and social conditions, the old conception of law is ill-fitted. It is necessary again to create respect for the law, because it is law. This long-forgotten message of the School of Law has acquired a new actuality. A study of their doctrines, with all their one-sidedness, has therefore even more value than a purely historical one : it may help to give the Chinese of to-day a deeper understanding of the great problem of the sovereignty of law, with which they are confronted. 


\section{CHAPTER IV}

\section{THE TEXT OF THE BOOK OF LORD SHANG}

\section{History of the Text}

p.131 Han Fei-tzu mentions the 'Law of Kung -sun Yang" (515) or the 'Law of Lord Shang" (516) and says that

« in every house there are those who preserved the laws of Kuan Chung and Shang Yang (517).

This is the oldest reference to a book. Ssu-ma Chien at the end of his Biography of Shang Yang says :

«I have read the books K'ai-sai and Keng-chan by the Lord of Shang, which are in keeping with the deeds he did. There was indeed reason enough why he should have finally left a bad reputation in Chin.

The $7^{\text {th }}$ paragraph of the present book is called $\underline{K^{\prime} a i-s a i}$ and the $3^{\text {rd }}$ Nung-chan, which has the same meaning as Keng-chan. A section bearing that exact title does not now exist.

The Han Catalogue, under the heading 'School of Law", mentions "The Lord of Shang, in 29 sections"; under the heading "Military Treatises", "Kung -sun Yang, in 27 sections". This book is not heard of further, and is generally thought to have been a different one from the first (518); possibly paragraphs 10, 11 and 12 are reminiscent of it.

p.132 In the "Collected Writings of Chu-ko Liang" mention is made of "The Book of Lord Shang", as a book worthy of study : 'The 'First Ruler' gave on his deathbed the following recommendation to the 'Later Ruler' (519): 'Read the Han books, the $\mathrm{Li}$-chi, and, when you have leisure, glance over the various Philosophers and the Six Chapters on Strategy (520); the Book of Lord Shang benefits one's knowledge."

The next reference to the book occurs in the catalogue of books in the History of the Sui dynasty (589-618), which mentions : "The Lord of Shang, in 5 chapters, written by the minister of Ch'in, Wei Yang".

The chapter on literature of the Old T'ang History mentions "The Book of Lord Shang, in 5 chapters," and the corr esponding chapter in the New T'ang History repeats this statement and adds: "written by Shang Yang, by some called Shang-tzu," i.e. the Philosopher Shang.

According to the Ch'ün-shu-chih-yao (521), compiled by Wei ${ }_{\mathrm{p} .133}$ Cheng in 631, chap. 36, there existed in Shang-chün-tzu a section called Liu fa-p’ien, 
"The Six Laws", which was placed before what is now the $14^{\text {th }}$ paragraph, the Hsiu-ch'ïan-p’ien, "The Cultivation of the Right Standard". A small part of that section is there reproduced (see p. 160). Ssu-ma Cheng, who in the eighth century wrote the Shih-chi-so-yin, "Explanations of Obscure Passages in the Shih-chi", mentions the book in connection with his explanation of the above-quoted sentence in Shih-chi and shows at the same time that he had probably never seen the work in question. For he says :

«In the Book of Lord Shang, k'ai means that, if penalties are severe, government measures may develop ( $\left.k^{\prime} a i\right)$, and sai means that, if favours and rewards are distributed, government measures are obstructed (sai); the idea of it lay fundamentally in having severe penalties and few favours. Also in order to obtain new arable land he opened up the longitudinal and transversal paths, and he said that rank was awarded for cutting off an enemy's head : this is the Book on Agriculture and War' (Keng-chan-shu).

In the Sung dynasty the book is mentioned by the famous man of letters, Cheng Ch'iao (522), in the section "the School of Law" of the Compendium on Literature in his great work T'ung-chih (523). He repeats the statement of the Sui History and adds : 'In the Han dynasty there were 29 sections ; now three of these are lost".

p.134 The same statement is repeated by his younger contemporary, the well-known bibliographer, Ch'ao Kung-wu, in his Ch'ün-chai-tu-shu-chih (1151) under the heading "The School of Law". He also criticizes Ssu -ma Cheng's explanation of the phrase in the Shih-chi and quotes some part of K'ai-sai-p'ien, the $7^{\text {th }}$ paragraph of the Book of Shang-tzu, as he calls it.

Ma Tuan-lin in his great Wen-hsien-t'ung-k'ao, in the section on Miscellaneous Authors, speaks of "Shang-tzu in 5 Chapters"; so does the Sung history.

It seems that during the Sung dynasty different copies of the book existed. For Ch'en Chen-sun, whose hao was Chih-chai, and who was promoted to chü-jen in the Tuan-p'ing period (1234-1237) in his Catalogue of books from various family-libraries, called Chih-chai-shu-lu-chieh-t'i under the heading "Various A uthors" mentions "Shang-tzu in 5 Chapters, written by Wei Yang, the Chancellor of Ch'in ; in the Han Catalogue 29 sections are mentioned, but now there are 28, of which again one section is lost". This may have been a copy in which the section on "The Six Laws" still formed part.

In the 'Extract of the table of contents of the Ssu-k'u-ch'üan-shu' (1782), ch. 101, the sections on philosophers, II, School of Law, the matter is discussed at some length. It is pointed out how the book was originally known under the ${ }_{\text {p.135 }}$ title of "The Book of Lord Shang" and it is said that from the Sui History on, the name Shang-tzu had come into use. (This is not quite correct, as will be clear from the foregoing.) Whereas in the Sung dynasty two different copies are mentioned, one of 26 sections, and one of 28 , at the time of writing only 24 sections were really extant, the $16^{\text {th }}$ and $21^{\text {st }}$ having also 
been lost, so it cannot be the same copy which, for example, Ch'ao Kung-wu had seen. It is further pointed out that in the T'ang dynasty the book cannot have been widely known, as Ssu-ma Cheng made the mistake, mentioned above, in his explanation of the words k'ai and sai in the Shih-chi and had therefore evidently never seen the actual work.

The first printed edition seems to have been published by Cheng Ts'ai (524), who flourished in the Shun-yu (525) period of the Sung dynasty. The existence of a Yüan edition is assured by Yen Wan-li (526). There were several Ming editions : one by Feng Chin (527) in 1535 ; one in the collection Erh-shih-tzuch '̈ian-shu. "The complete works of the 20 Philosophers", published by Wu Mien-hsüeh (527a); one by Ch'eng Jung in the great collection Han-wei-

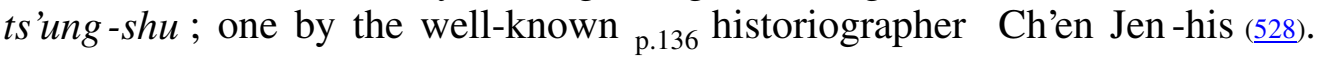
Wang Shih-jun (529), who has consulted this last edition, says that it has 24 sections, beginning with that called "Reform of the Law", and ending with "The fixing of rights and duties"; this is, he says, also the case with the edition of the Ch'ung-wen-chü (530). The well-known writer Kuei Yu-kuang (531), about the middle of the sixteenth century, in his Chu-tzu-huihan published an abbreviated text, in which he only gave what are now the second, the third, the sixth, the seventh, and the fifteenth paragraphs, omitting all corrupt and obscure places (532).

In the Ch'ing dynasty, several of the best scholars have worked on the text of Shang-tzu.

In 1793 Yen Wan-li published an edition of the Book of Lord Shang, which was reprinted in 1876 by the Chê-chiang-shu-chü, in the "Collection of the Twenty-two Philosophers". This edition, which is the best known, I have taken as the basis of my translation. Yen recalls, in his introduction, how in the Sung dynasty there were copies of 26 and 27 paragraphs. He bases himself upon a ${ }_{\text {p.137 }}$ printed copy of the Yuan dynasty, which had 26 paragraphs, of which the $16^{\text {th }}$ and $21^{\text {st }}$ were lacking, so in reality therefore it had only 24 paragraphs, just as was the case in the printed copy of Fan Ch'in (533), which was current in his time.

Later he obtained a very good MS. copy, which came from the hands of Ch'in Ssu-lin (534). Yen concludes that in the Sung dynasty there were evidently no printed copies, or that at any rate, if there were, they must have been rare (535). Many corrupt places were corrected by Yen (536).

After this we should mention the work done by Yü Yüeh; a chin-ship of the promotion of the year 1850, who reckoned to be of the school of the well-known Wang Nien-sun (537). Yü lived to the end of the Kuang-hsü period, to be 86 years of age. Among the numerous books of this distinguished p.138 scholar, collected as the Ch'un-tsai-t'ang-ch'̈̈an-shu, containing more than 500 chapters, is the Chu-tzu-p'ing-I, "A Critical Discussion of the Minor Philosophers", in 50 chapters, one of which treats of Shang Yang. For this he made use of the printed text of Cheng Ts'ai (538), of the Sung dynasty, and of an edition of Sun Hsing-yen (539). He also consulted the text of the 
Shih-shih-hsien-ch'in-chu-tzu (540),'The Minor Philosophers of the Pre-Ch'in period, by Shih".

Sun I-jang (541), an excellent scholar and well known for his work on Mo-tzu, tried his hand at Shang Yang's text after this. He had the benefit of a copy from the hands of Chien Hsi-tsu, who lived about the middle of the nineteenth century and who published it in his big collection called Chih-hai ; also of a copy which had been corrected by that brilliant scholar Yen K'o-chün (542). The results of Sun's study have been incorporated in the Cha-i, a work of 12 chapters (543).

p.139 In the fourth year of the Republic, i.e. in 1915, an edition was published (544), which incorporated the critical results, to which these distinguished men of letters had arrived, and which gave a great number of new emendations. This was the work of Wang Shih-jun and was called the Shang-chün-shu-chiao-ch'üan, "A Critical Examination and Explanation of the Book of Lord Shang". This book forms part of a series, the Wen-chihsien-ts'ung-shu, in which the author also intended to publish Yin Wen-tzu, Kung-sun Lung, Têng Hsi-tzu, and Kuei Ku-tzu (545). There is a complimentary preface by Ch'en Ch'ao -chüeh, and another by Liu Tzu-ho ; from that of the latter it appears that the author has also studied abroad. It is a piece of careful work; the author states that for ten years he has been at intervals engaged on this study. Taking Yen's text as his basis, he has made use of the critical work done by Yü and Sun and has also consulted the text as published by the Ch'ung-wen-chü (546) in Hupei, which gives the old reading, and therefore sometimes permits reconstruction of the original. Though his explanations are sometimes a little pedantic and certain emendations seem unnecessary, on the whole his judgment is sound and I have ${ }_{\text {p.140 }}$ found it the best edition of the text. Unfortunately it is not free from printing errors.

Of another modern edition little good can be said. It is called Shang-ch"n-shu-hsin-shih "A New Explanation of the Book of Lord Shang", and is published in the collection Ch'i-sheng-chai-ts'ung-shu, in which also editions of the Lun-yü, Li-chi, Mo-tzu, Kuan-tzu, Han Fei-tzu, etc., have appeared. It has had the honour of two editions, the first in the seventh year of the Republic (1918), the second in the eleventh year (1922). It is capped with a preface by the author's father and complimentary letters and verses from the author's friends, one of whom is the former Prime Minister of the Republic, Hsiung Hsi-ling. The author is Yin T'ung -yang (547). He submitted the draft to his father Yin Ch'ien, who enriched it with his own remarks, and tells us in his preface that in his youth he himself had studied with the well-known Wang K'ai -yün (548). Yet the book is a poor production; the author, who has studied some modern law, tries to find everywhere modern conceptions of law ; he has not made use of the excellent text-critical work of Yü Yüeh and Sun I-jang, nor did he know Wang Shih-jun's edition, and in his own interpretations of the text he often goes hopelessly wrong. In some rare cases have I found a text-critical remark, which ${ }_{\text {p.141 }}$ has been useful. If, however, from a philological point of view the book is rather a failure, it has a certain 
value on account of the references to similar works such as Han Fei-tzu, Kuan-tzu, etc., which it gives, although many of these also are absolutely useless. Generally I have passed over his interpretations in silence, only mentioning his views in some instances (549).

\section{The Authenticity of the Text}

The first criticism as to the authorship of the Book of Lord Shang appears during the Sung dynasty. Huang Chen, a chin-shih of the Pao-yu period (1253-9), writes in his Huang-shih-jih-ch'ao, chap. IV :

«Shang-tzu, is a book by Kung-sun Shang Yang. It begins with 'Cultivation of Waste Lands' and urges people to farm and fight. Its text is confused and incoherent and cannot be divided into sentences. Now after a thousand years, one's mind and eyes become still confused by the opening chapter $(550)$; how much more this must have been the case with those who at the time suffered (the author's) iniquities in their own bodies ! However, when the Court confers the title of Yü-shih, censor, in reality it applied the teaching of this book, and the fact that, whenever affairs arise, law officials are consulted, finds also its origin in this book. Those in later generations, who in everything take the law as basis for their decisions, should understand where it comes from. It may perhaps be objected that, as Yang was also a capable p.142 law-official, his book should not be so confused and disorderly; and it is almost impossible to know whether it is genuine or spurious.

The Chou-shih-shê-pi, also a work of the Sung dynasty, says :

« To the Book of Shang Yang much later material has been added, and words from others have been taken, which do not belong to the original text. The essential and important places of the book are already completely contained in the Biography in the Shih-chi. What has now been preserved are, on the whole, verbose and exaggerated expressions which do not deserve any attention. ... What the Shih-chi did not contain, has been gradually added on by the makers of books and was not material that had been generally current. How should it have been possible, at the time when Ch'in first began to be prosperous, that official titles at the Court were obtained by-means of wealth, and how should it have been possible before Duke Hsiao, that on the one hand power was sold in order to obtain wealth and that on the other inferior officials thereby obtained promotion? (551)

The Ssu-k'u-ch'üan-shu-tsung-mu-t’i-yao (1782) which has been quoted before (552), in discussing this criticism, says that the theory about the later 
additions in Shang Yang's book, is merely a hypothesis and cannot be proved. However, from the facts as recorded in the Shih-chi, it appears that after the death of Duke Hsiao, Shang Yang had to fly for his life; and soon after was executed, so he cannot possibly have had time to compose a book. On the other hand, if he had written it during the ${ }_{\text {p.143 }}$ time he held office at Duke Hsiao's Court, how is it that the latter's posthumous name is mentioned in the first section? Probably his followers of the School of Law collected his sayings and composed the book, just as in the case of Kuan-tzu, who died before Duke Huan, and yet the posthumous name of the latter occurs repeatedly in the book now bearing Kuan-tzu's name. There are many books of this kind; but as we cannot discover the name of the real author, we continue to call the book by the name of the man to whom it has been ascribed.

The "Abbreviated Catalogue to the Ssu-k'u-ch'üan-shu", in chap. 10, the section on philosophers, 3, School of Law, also expresses its belief that the book was composed by Shang Yang's disci ples, as,

« although he cannot have written it himself, yet on the other hand the words of the book are so harsh and terrible, that they appear to be his sayings transmitted by his followers. It is not the work of post-Ch'in people

Modern scholars have, on the whole, taken a rather critical view. Hu Shih points out a few of the anachronisms in par. 15, which we shall discuss later, and concludes that the book must have been composed after Shang Yang's death so that it cannot be regarded as "genuine" (553). Liang Ch'i-ch'ao is of opinion that the Book of Lord Shang, like Kuan-tzu, has not been written by the man with whose name it is connected, but that it has been put together towards the end of the "Period of the Warring States" by people who were interested in the School of Law; its value therefore is similar to the collections on the Rites, $l i$, by the two cousins Tai (554).

A. Ivanov, who, among foreign scholars, has been the first to devote a monograph to one of the writers of the School of Law, viz. Han Fei-tzu, states in his introduction, that he regards the Book of Lord Shang to be in a well-finished condition. "We do not find in it any important repetitions and foreign interpolations" (555).

Dr. A. Forke (556) does not believe that Shang Yang wrote the Book himself; he thinks that after his death his sayings were collected by his adherents, specially those who, as officials, were interested in law and administration. Some sections (557) may have been based on official reports which Shang Yang submitted to the prince, because the expression ch'en 'I, your servant" occurs in them; some other sections, which are very corrupt (558), should in Professor Forke's opinion perhaps be regarded as interpolations.

H. Maspero thinks that the Book was composed some time in the third century by an unknown author ; he asserts, however, that this original work is 
now lost and that the ${ }_{\mathrm{p} .145}$ present "Book of Lord Shang" is a fake of the time of the Six Dynasties (559) (220-587).

A different point of view is represented by Dr. Kuo-cheng Wu, who regards the Book as the work of Shang Yang himself and believes that it is the best of all the legalistic writings of that period, both from the standpoints of its authenticity and of its value ( $\underline{560}$ ). He does not, however, give the reasons on which this opinion is based.

In view of these very different opinions as to the value of the text, it is necessary to undertake a careful investigation of it.

As has been pointed out by the Chinese critics just quoted, it is in itself highly improbable that a statesman like Shang Yang, who is said to have been killed almost immediately after resigning his office, would have found an opportunity for writing at all, and even a cursory examination of the text shows that he cannot have been the author. In the $1^{\text {st }}$ paragraph we see that Duke Hsiao is referred to by his posthumous name; in paragraph 15 the person addressed is called King, a title that Duke Hsiao's successors adopted more than ten years after the death of Shang Yang; also the posthumous title of King Hsien of Wei, who died in 319, is mentioned, as are various events, of which the latest took place in 260. At the end of paragraph 20 references are made to events that happened in 301 and 278, and there is even a probable allusion to the partition of Ch'u in 241 .

Not only, however, can Shang Yang himself not have been the author of the present book, but the various parts of it ${ }_{\mathrm{p} .146}$ certainly do not come from the same hand. There is a vast difference in style in the 24 paragraphs which have been preserved ; some are extremely terse and concise, others are long-winded or use in part a different vocabulary. This difference in style corresponds very nicely with a difference in ideas.

Let us first examine some general particularities. The only sections where Shang Yang, here called Kung-sun Yang, is mentioned at all, are pars. 1 and 26. There, he is supposed to be in conversation with Duke Hsiao. Now par. 1, the famous discussion anent the reform of the law, shows a remarkable resemblance to another famous conversation, held by Duke Wu-ling of Chao (325-299), with his ministers, about the adoption of the dress of the barbarians ; this is given in the Chan-kuo-ts' $\hat{e}$ (561), and has also found its way into the Shih-chi (562). As will be duly pointed out in the notes to the translation, practically the whole of this section is found in these ; from the disjointed way in which the phrases occur there, it seems more likely that the account in Shang-tzu has been taken from them rather than the other way about. The conversation in this first paragraph is also reproduced in the Biography in the Shih-chi, with certain abbreviations, so that this piece of pure literature must have been composed before Ssu-ma Chien's time. It has no connection with the rest of the book and merely serves as an introduction.

The $26^{\text {th }}$ paragraph is of a very different type from this. It seems to presuppose the official organization of the Ch'in dynasty; it speaks of the 
necessity of establishing ${ }_{\text {p.147 }}$ law-officials, in the various feudal states, in the same way as this was done in Ch'in (563), which would point to the beginning of that period. Also, however, it mentions an indication of time whereby month, day and hour should be given (564). As the indication of hours by cyclical characters did not exist before the Han dynasty, this might point to that period ; it is, however, possible that only indications like "the crowing of the cock", etc., which were in vogue much earlier, are meant. The ideas developed in this paragraph are certainly of a later date than those in several other paragraphs (565).

The official hierarchy of the Ch'in state is also the basis of the very corrupt par. 19. In spite of a few unintelligible passages it is clear that it simply develops the idea that promotion is given according to the number of heads cut off, which has already been explained (566). I should not therefore regard it as a later interpolation, as Professor Forke (567) does, but rather as belonging to the old part of the book ; the style is very concise.

Apart from the last part of 20, the only other section where special mention is made of Ch'in is par. 15. This is in the form of a report or speech ; we have already seen (568) that it contains several anachronisms, so that it cannot have been written before the second half of the third century ; its style is certainly not of a very old type.

A characteristic of this paragraph is its illustration by historical events. The same is done in pars. 17, 18, and the last part of 20. The latter, because of the anachronisms mentioned (569), cannot very well be older than the second half ${ }_{\text {p. } 148}$ of the third century. Par. 17 is very long-winded; it is perhaps the latest paragraph of the whole book.

Like par. 15, the paragraphs 17 and 18 are in the form of a report or speech, and the speaker refers to himself as [], "your servant". This same figure of speech occurs in pars. 6, 9, 23, 24 and 25. Of these 6 and 9 are of a simpler type than the last three mentioned.

The paragraphs 10, 11 and 12 stand entirely by themselves, dealing with military matters. They are chiefly based on old sayings, partly from a book called the "Art of War". These paragraphs may be remnants of the "Military Treatise in 27 sections of Kung-sun Yang", mentioned by the Han catalogue (570).

Of a very peculiar type are the paragraphs $4,5,13$, and 20 . They are very corrupt and can only be well understood in conjunction with each other. It is clear that in their present form they are not the original paragraphs, for the same statements and phrases are repeated over and over again in them. They are probably attempts to reconstruct the original sections, but evidently the material which the unknown editor found was insufficient to go round, so he contented himself with repetitions. This at any rate shows that he was extremely conscientious, as a faker would have invented freely as the need arose. The style of these sections is very terse and concise ; no other particles occur in them except [][][][][][][][] ; they have no other style of arguing than 
the chain of parallelisms : "if this is the case, then ...; if that is the case, then ..." Par. 13 is in part the same as par. 53 in Han Fei -tzu, which does not belong to the part of that book, which is generally p.149 ascribed to that author, but need not however be of a later date. After careful study both of the form and the contents of these paragraphs I have come to the conclusion that these fragments belong to the oldest portions of the Book of Lord Shang, although there are probably some later admixtures (571).

Of the remaining paragraphs, 2 and 3 show an old style similar to that of those just named, but 3 certainly has later additions, like the part beginning with : "Consequently all the lower officials say" (572), which seems to be an imitation of paragraph 14 in Han Fei-tzu. This third section is now called Nung-chan and may therefore be more or less the same as that indicated by Ssu-ma Chien as Keng-chan which means the same thing.

Paragraph 7 has the title of the other book that Ssu-ma Chien mentions, viz. K'ai-sai. These expressions do indeed occur in it, but I am inclined to think that this title belonged originally to par. 8, where the terms are used in a far more typical sense of "opening", $k$ 'ai, only one gate to riches and honour, i.e. agriculture and warfare, and by closing, sai, all other gates. The titles and numbers of the paragraphs may have easily been confused, when editing the book, and we have seen that Wei Cheng mentions a paragraph before what is now 14, which was altogether omitted later in numbering the paragraphs (573). The ideas of 7 and 8 fit in with those of 4, 5, 13 and 20 ; their style generally resembles most that of 6 and 9 .

Paragraph 14, which we have not yet discussed, is very interesting, but I do not think that it belongs to the old part of the book. Its style is different, and the ideas which it develops are too advanced. It speaks of such things as p.150 ming-fen 'to make clear everyone's rights and duties", with which the $26^{\text {th }}$ paragraph is occupied, although it is of an older type than this.

Finally we have the $22^{\text {nd }}$ paragraph ; this is of little importance. It seems to be of different, and certainly of later, origin ; whereas in other paragraphs severity of punishments and scarcity of rewards are generally urged, this paragraph pleads for liberality in the bestowal of rewards.

Thus we find different strata: paragraphs 4, 5, 13 and 20 (except the last part), containing old fragments, as well as 19 ; to this group may belong paragraphs 2 and 3, with certain exceptions ; 7 and 8 ; the group in which [] occurs, of which 6 and 9 are older, the other paragraphs being later, 17 certainly so ; 1 and 26 being supposed conversations but also certainly later, and 26 being similar to 23, 24 and 25 ; and finally 10, 11 and 12 containing old fragments.

We shall now give some examples of difference in vocabulary between the various paragraphs. Although it has not been possible to establish series of words, which occur regularly only in certain paragraphs, there are some key-words which are limited to a few paragraphs. "lice, parasites" is only found in pars. $4,5,8,13,20$; [] in the sense of "to unify, oneness" in pars. 2, 
$3,4,6,8,11,13,17,18$; [] "simple" in pars. $2,3,4,6,7,8,13,20$; [] 'to consolidate" in pars. 3, 5, 8 ; the expression [][] 'intelligent prince" in pars. 3, $6,8,9,23$; [][] 'intelligent ruler" in pars 7, 9, 14, 18, 20, 23, 25, 26, having 9 and 23 in common with the synonymous expression just mentioned ; [] "to relax" in pars. 14, 15, 20, 23, 25 ; [] "measure" in pars. $6,7,8,9,14$; "to debar" in pars 5, 6, 7, 8, 18, 22 ; [] "weight of the balance, deciding influence, standard, authority" in pars. 2, 3, 6, 8, p.151 14, 20 ; [] "condition", sometimes rendered by "power", in pars. 6, 7, 11, 18, 20, 24, 25, 26 ; [] 'method" in pars. $3,6,10$; [] "number, statistics" in pars. 3, 4, 6, 9, 13, 14, 15, 24, 25 ; etc. It does not seem necessary to accumulate these examples. There is little regularity ; generally, however, it may be said that the last four paragraphs of the book show the same vocabulary, and this is on the whole very different from that of pars. 4, 5, 13 and 20.

It is interesting to pursue our study of the text in some more detail. Although it is quite clear that the styles of various paragraphs differ greatly, it is not so easy to define wherein exactly the difference lies. I have therefore followed the excellent example set by Karlgren in his important treatise "On the Authenticity and Nature of the Tso Chuan" (574), and have undertaken an examination of the grammatical auxiliaries. Apart from the few hinges on which every Chinese phrase turns, like [][][][][][][], which recur with monotonous regularity, there is a great paucity of functional auxiliaries. Karlgren examined the following words ... I have included in my investigation .... The results are as follows ${ }^{1}(\underline{575)}: \ldots$

p.153 In the first place, this grammatical analysis confirms, definitely, the connection between the various sections, which was established on general philological grounds, and allows of further conclusions. Paragraphs 4, 5, 13, and 20 are found to be practically free from all the characters in the list ... Par. 13 has one [] in the opening passage, which it has in common with the spurious paragraph 53 in Han Fei-tzu, under the influence of which it has probably been reconstructed. Par. 19 has only one [] in a doubtful case (576), and twice it has []. In pars. 1 and 26 particles are frequent, as they are in the group where [] is used, i.e. $6,9,15,17,18,23,24,25$, with the marked exception of 23, where they are entirely missing. In pars. 10, 11, and 12 particles occur, though they are not numerous ; likewise in pars. 7, 8, 14. and 22. In par. 2 only the particle [] is found with great frequency, whereas par. 3 is particularly rich with particles, but only in certain parts which are of a different style from the rest of the paragraph.

Further analysis reveals that there is a distinction in the use of [] and [], the latter never occurring in the sense of "if", but being the predominant word for "like" ; [] as "like" is only found in pars. 8, 10, 15, 17, 18, the latter part of 20 and 25 , and of these three times (par. 10, 5a;18, 8b;20. 5a) it is in

\footnotetext{
${ }^{1}$ [css : les hypothèses et les résultats présentés ne peuvent être totalement exploités sans les caractères chinois. Nous avons cependant gardé l'expression du raisonnement de l'auteur.]
} 
quotations. In the other cases it is either in the combination [][] or with a negative. [], though it does occur, is very rare ; once only (par 3, 7a) does it form part of the text ; the only other place where it is found (par 17, ${ }_{\text {p. } 154} 6 \mathrm{a}$ ) it belongs to a historical quotation. The exclamatory [] is always found in connection with an interrogative, like [] or an intensifying particle, like [], chiefly in quotations or historical allusions. Only twice (par. 15, 2b, 3a) does it form part of the ordinary text. With regard to [] and (], the latter is only used in the nominative (par. 1, la; 7, 10a; 15, 3b) and genitive (par. 7, 10b) ; the former occurs as nominative plural (par. 3, 7ab ; 18, 9a) ; as accusative (par. 1, $1 \mathrm{a} ; 18,10 \mathrm{a} ; 25,10 \mathrm{a}$ ), and as dative plural (par. 17, 6a with []).

It is of interest to compare these results with those given in Karlgren's study. I may here briefly recall the method which he devised. Taking as his starting point the Tso-chuan, he compared the use of grammatical auxiliaries in this work with those in other books, and came to the conclusion that a marked difference in the employment of certain particles may be traced in the pre-Han literature, which was afterwards effaced, owing to the syncretic nature of the Chinese language, which enriched itself with elements of different origin. Two distinct dialects may be distinguished, the first used in the Tso-chuan, and the second in the Lun-yü, Mencius, etc., called by Karlgren the Tso dialect and the Lu dialect respectively. Further a remarkable uniformity in grammar can be shown to exist in all the books of the third century B.C., which Karlgren examined, viz. the Lu-shih-ch'un-ch'iu, the Chan-kuo-ts'e, Hsün-tzu, and Han Fei-tzu. The main results, as far as they concern us here, are as follows ${ }^{1}: \ldots .$. .

Summing up these results, Karlgren states that the third century texts have a language, which differs considerably from that of the Lu dialect, and even much more so from that of Tso. Unlike the former it has no [] and [] which are such salient features of this dialect. Unlike the Tso dialect, it has [] as well as [] for "like", "as" ; it has the preposition [] and, to a small extent, the final [] ; it lacks the preposition [], and there is no functional distinction between [] and [], and finally it possesses, though with varying frequency, the final [].

Karlgren gives a table $(\underline{577})$ where in the case of the particles sub $2^{\circ}, 3^{\circ}, 4^{\circ}$, $5^{\circ}, 6^{\circ}, 9^{\circ}$, the letter $a$ indicates their existence and the letter $b$ their absence ; ...

p.157 Together with the Shu-ching, Shih-ching, Lu dialect, Kuo-yü, and Tso-chuan, Karlgren places in' this table, Chuang-tzu, which, however, shows certain tendencies that are rare in the ordinary third century texts (578). I, therefore, add the characteristics of the general type of these texts, neglecting exceptions, and place them side by side with those of Shang-tzu's text. We then get the following synopsis :

\footnotetext{
1 [css : à nouveau, les résultats présentés ne peuvent être totalement exploités sans les
} caractères chinois.] 


\begin{tabular}{|c|c|c|c|c|c|c|c|c|}
\hline & Shu & Shih & Lu & Chuang & Kuo-yü & Tso & 3rd Cent & Shang \\
\hline $1^{\circ}$ & $\mathrm{a}$ & $\mathrm{c}$ & $\mathrm{b}$ & $\mathrm{b}$ & $\mathrm{b}$ & $\mathrm{c}$ & $\mathrm{b}$ & $\mathrm{b}$ \\
\hline $2^{\circ}$ & $\mathrm{b}$ & $\mathrm{a}$ & $\mathrm{a}$ & $\mathrm{b}$ & $\mathrm{b}$ & $\mathrm{b}$ & $\mathrm{b}$ & $\mathrm{b}$ \\
\hline $3^{\circ}$ & $\mathrm{b}$ & $\mathrm{a}$ & $\mathrm{a}$ & $\mathrm{b}$ & $\mathrm{b}$ & $\mathrm{b}$ & $\mathrm{b}$ & $\mathrm{b}$ \\
\hline $4^{\circ}$ & $\mathrm{b}$ & $\mathrm{b}$ & $\mathrm{a}$ & $\mathrm{a}$ & $\mathrm{b}$ & $\mathrm{b}$ & $\mathrm{b}$ & $\mathrm{b}$ \\
\hline $5^{\circ}$ & $\mathrm{b}$ & $\mathrm{b}$ & $\mathrm{a}$ & $\mathrm{a}$ & $\mathrm{b}$ & $\mathrm{b}$ & $\mathrm{b}$ & $\mathrm{b}$ \\
\hline $6^{\circ}$ & $\mathrm{b}$ & $\mathrm{a}$ & $\mathrm{b}$ & $\mathrm{b}$ & $\mathrm{a}$ & $\mathrm{a}$ & $\mathrm{b}$ & $\mathrm{b}$ \\
\hline $7^{\circ}$ & $\mathrm{b}$ & $\mathrm{b}$ & $\mathrm{a}$ & $\mathrm{a}$ & $\mathrm{c}$ & $\mathrm{c}$ & $\mathrm{a}$ & $\mathrm{a}$ \\
\hline $8^{\circ}$ & $\mathrm{b}$ & $\mathrm{c}$ & $\mathrm{a}$ & $\mathrm{a}$ & $\mathrm{a}$ & $\mathrm{a}$ & $\mathrm{a}$ & $\mathrm{a}$ \\
\hline $9^{\circ}$ & $\mathrm{b}$ & $\mathrm{b}$ & $\mathrm{b}$ & $\mathrm{a}$ & $\mathrm{b}$ & $\mathrm{b}$ & $\mathrm{b}$ & $\mathrm{b}$ \\
\hline
\end{tabular}

p.158 So the grammatical affinity of those parts of Shang-tzu where these particles are found, to a certain type of third century texts is complete, with the reservations indicated in the footnotes to the synoptic table ${ }^{1}$. No other third century text shows such a strong resemblance to our text as that of Han Fei-tzu. It is the only one in which [] (sub $4^{\circ}$ ) as a final is also entirely missing. This impression is completely confirmed by a literary analysis : in the notes on my translation I have on twenty-nine occasions had to refer to Han Fei-tzu for the same or similar expressions, and no doubt this number could be increased. Most of these references are to sections the authenticity of which is in doubt; of those admitted as genuine by Hu Shih (579), I have only given references to par. 40, 43, and 45, and of these par. 43 is specially devoted to a criticism of Shang Yang. It may be supposed that much of the two books goes back to a common inheritance of the School of Law ; and it is not, therefore, surprising that I have also found occasion to refer twelve times to Kuan-tzu. Von der Gabelentz, in his Vorbereitendes zur Kritik des Kuan-tsï (580), says that he found nothing in the Shang-chün-shu which referred to Kuan-tzu, and this is true to the extent that Kuan-tzu is nowhere quoted, but there are certainly parallel expressions and ideas, and I am sure that a minute examination of Kuan-tzu would bring to light a great many more than I have found. In view of the highly complex character ${ }_{\text {p. } 159}$ of the text of Kuan-tzu (581), which must be a medley of elements of very different dates, it is interesting to find these parallelisms in our text.

To sum up : the conclusion to which this examination leads us can be no other than this : - the present Book of Lord Shang is a compilation of paragraphs, of different styles, some of which are older than the others; the older ones contain probably the mutilated remnants of the original book that has been lost ; the later ones date, on the whole, from the third century. Some, like the $26^{\text {th }}$, seem to date from the last quarter of that century, and as I have no wish to be dogmatic, I admit the possibility that a paragraph like the $17^{\text {th }}$, although in the use of particles it shows the third century characteristics, may nevertheless be considerably later, because it is much more verbose than texts of that period usually are. The other paragraphs are, however, valuable, either because they bring us in touch with what were, I believe, the original ideas of the School of Law, or because they shove the later phases of its development.

\footnotetext{
${ }^{1}$ [css : réserves non reprises, pour les mêmes motifs]
} 
We do not know at what date the compilation of the Book in its present form took place ; it may have been at the time of the Six Dynasties, as Maspero suggests (582). We may safely admit, with that scholar, that the present book is a "faux", in the sense that it is not the work in its original form ; I believe, however, to have shown that we have no right to reject it, as if it were a fake without value. 


\section{APPENDIX I}

A lost paragraph

p.160 In the $36^{\text {th }}$ chapter of the Ch'ün-shu-chih-yao, by Wei Cheng (631), the following is quoted as part of the now lost section Liu Fa, "The Six Laws", which had its place before what is now the $14^{\text {th }}$ paragraph. As the Ch'ün-shu-chih-yao has been lost (583) in China since the Sung dynasty this section has been left out in all the editions of Shang-tzu, and not even in numbering the paragraphs has a place for it been kept. In the early editions, like those of Ch'en Jen-hsi of the Ming dynasty and the Ch'ung-wen ed., no numbers were attached to the paragraphs, but Yen numbered them and left at the end of the book room for the three, which were lost. Wang Shih-jun accidentally followed him in this, but corrects the mistake in a note on p. $2 \mathrm{a}$ of his preface.

The portion of the paragraph which has been preserved runs as follows :

«The ancient Kings established the laws in accordance with the times, they regulated affairs, calculating what deserved attention. Law, being fitting for its own time, there is order ; affairs fitting in with those things to which attention is given, there is success. So it follows that laws create order when it is the proper time for them, and that affairs obtain success when they are apt. But now the times have changed ${ }_{\text {p.161 }}$ and yet the laws are not reformed; what deserves attention has altered and yet affairs are transacted in the old way. Thus the laws and the times are contrary to each other and affairs and that, to which attention is given, are different from each other. Therefore, though laws are established, disorder increases ; though one acts, giving attention to certain things, affairs fail. Consequently the way of a Sage in administering a country, is not to model himself on antiquity, and not to follow the present, but to establish success in a way which is fitting for the time (584), and to be able to escape whenever one is in difficulties. But now people may change their customs, but the laws are not altered, the conditions of the state may change their aspect, but in that to which one gives one's attention, one still follows the old way. Now law is the government of the people, and that, to which attention should be given, is the practical side of affairs. If a state fails in its laws it is in peril, and if affairs fail in their practical application they do not succeed ; and therefore, if the laws are not fitting for the times and that to which attention is given, does not fit in with practical needs, there has always been peril.

The paragraph is without much interest and certainly does not belong to the oldest part of the Book. 


\section{APPENDIX II \\ List of References}

p.162 In this synoptic table I have assembled all the references to other Chinese books, which I have thought necessary to give in the notes to my translation. Naturally the nature and value of these references differ widely, yet a general idea of various relationships may be obtained by a glance at this list. I only give the paragraphs. p.163

\begin{tabular}{|c|c|c|c|c|c|c|c|c|c|c|c|c|c|c|c|c|c|c|c|c|c|c|c|}
\hline & 1 & 2 & 3 & 4 & 5 & 6 & 7 & 8 & 9 & 10 & 12 & 13 & 14 & 15 & 17 & 18 & 19 & 20 & 22 & 23 & 24 & 25 & 26 \\
\hline Shih-chi & 68 & & & & & & & & & & & & & $\begin{array}{c}2 \\
47 \\
4\end{array}$ & \begin{tabular}{|c|}
5 \\
39 \\
4
\end{tabular} & & & 23 & & & & & \\
\hline Chan-kuo-ts'ê & 6 & & & & & & & & & & & & & & & & & & & & & & \\
\hline Hsin-hsü & 9 & & & & & & & & & & & & & & & & & & & & & & \\
\hline Han Fei-tzu & 18 & & 14 & 8 & 54 & $\begin{array}{l}56 \\
15\end{array}$ & $\begin{array}{c}7 \\
54 \\
30\end{array}$ & $\begin{array}{l}13 \\
54\end{array}$ & $\begin{array}{l}35 \\
56\end{array}$ & 9 & & 53 & $\begin{array}{c}43 \\
36 \\
9 \\
15\end{array}$ & & 34 & $\begin{array}{l}30 \\
48 \\
50 \\
36\end{array}$ & 43 & & & $\begin{array}{l}45 \\
19\end{array}$ & 45 & & 40 \\
\hline Kuan-tzu & & & & & 15 & & 3 & & $\begin{array}{l}20 \\
67 \\
\end{array}$ & & & 73 & 52 & & 16 & $\begin{array}{l}53 \\
3 \mathrm{x}\end{array}$ & & & & & & $\begin{array}{l}67 \\
16 \\
\end{array}$ & \\
\hline Lü-shih-ch’un -ch’iu & 2 & 8 & $\begin{array}{l}26 \\
2 x\end{array}$ & & & & & & & & & & & & & & & & & & & & 17 \\
\hline Ho Kuan-tzu & & & 6 & & & & & & & & & & & & & & & & & & & & \\
\hline Huai Nan-tzu & 3 & & & & & & & & & & & 17 & & & & & & 15 & & & & & \\
\hline Mo-tzu & & & & & & & & & & & 70 & & & & & & 62 & & & & & & \\
\hline Hsün-tzu & & & & & & & & & & & & & & & & & & 10 & & & & & \\
\hline Sun-tzu & & & & & & & & & & $\begin{array}{l}11 \\
2 \mathrm{x}, \\
1,3 \\
9,4\end{array}$ & & & & & & & & & & & & & \\
\hline Han-shih-wai-chuan & & & & & & & & & & & & & & & & 2 & & & & & & & \\
\hline Li-chi & & & & & & & & & & & & & & 17 & & & & & & & & & \\
\hline Chi-chung-chou-shu & & & & & & & & & & & & & & 5 & & & & & & & & & \\
\hline Tao-tê-ching & & & & & & & & & & & & & & & 4 & 33 & & & & & & & \\
\hline Mencius & & & & & & & 2 & & & & & & & & & 6 & & & & & & & \\
\hline
\end{tabular}




\author{
T R A N S L A T I O N \\ of the
}

B OOK OF LORD SHANG 


\section{CHAPTER I}

\section{Paragraph 1 \\ The Reform of the Law (585)}

p.167*1a Duke Hsiao discussed his policy (586). The three Great Officers, Kung-sun Yang, Kan Lung and Tu Chih, were in attendance on the Prince. Their thoughts dwelt on the vicissitudes of the world's affairs ; they discussed the principles of rectifying the law, and they sought for the way of directing the people. The prince said :

- Not to forget, at his succession, ${ }_{\text {p.168 }}$ the tutelary spirits of the soil and of grain, is the way of a prince ; to shape the laws and to see to it that an intelligent ruler reigns, are the tasks of a minister. I intend, now, to alter the laws, so as to obtain orderly government, and to reform the rites, so as to teach the people ; but I am afraid the empire will criticize me (587).

Kung-sun Yang said :

- I have heard it said that he who hesitates in action, does not accomplish anything, and that he who hesitates in affairs, gains no merit. Let Your Highness settle Your thoughts quickly about altering the laws and perhaps not heed the criticism of the empire (588). p.169 Moreover, he who conducts himself as an outstanding man is, as a matter of course, disapproved of by the world ; he who has thoughts of independent knowledge is certainly *1b despised by the world (589). The saying runs (590): « The stupid do not even understand an affair when it has been completed, but the wise see it even before it has sprouted (591). » One cannot let the people share in the thoughts about the beginnings of an affair, but they should be allowed to share in the rejoicings over the completion of it. The law of Kuo Yen says (592): "He who is concerned about the highest virtue is not in harmony with popular ideas; he who accomplishes a great work, does not take counsel with the multitude (593). » The law is an expression of love for the people (594); rites are a means for p.170 making things run smoothly (595). Therefore a sage, if he is able to strengthen the state thereby, does not model himself on antiquity, and if he is able to benefit the people thereby, does not adhere to the established rites.

Duke Hsiao expressed his approval, but Kan Lung said : 
- Not so. I have heard it said : «A sage teaches without changing the people, and a wise man obtains good government without altering the laws. » If one teaches in accordance with the spirit of the people, success will be achieved without effort ; if one governs, holding on to the law, officials will be well versed in it and the people will live quietly (596). Now, if Your Highness alters the laws without adhering to the old customs of the Ch'in state, and reforms the rites in order $_{*_{2} \mathrm{a}}$ to teach the people, I am afraid that the empire will criticize Your Highness, and I wish that You would reflect maturely (597).

Kung-sun Yang replied :

- What you, sir, hold is the p.171 point of view of the man-in-the-street. Indeed, ordinary people abide by old practices, and students are immersed in the study of what is reported from antiquity. These two kinds of men are all right for filling offices and for maintaining the law, but they are not the kind who can take part in a discussion which goes beyond the law. The Three Dynasties have attained supremacy by different rites, and the five Lords Protector have attained their protectorships by different laws. Therefore, a wise man creates laws, but a foolish man is controlled by them ; a man of talent reforms rites, but a worthless man is enslaved by them. With a man who is enslaved by rites, it is not worth while to speak about matters; with a man who is controlled by laws, it is not worth while to discuss reform (598). Let Your Highness not hesitate (599).

p.172 Tu Chih said :

- Unless the advantage be a hundredfold, one should not reform the law; unless the benefit be tenfold, one should not alter an instrument. I have heard it said that in taking antiquity as an example, one makes no mistakes, and in following established rites one commits no offence. Let Your Highness aim at that (600).

*2b Kung-sun Yang said :

- Former generations did not follow the same doctrines, so what antiquity should one imitate ? The emperors and kings did not copy one another, so what rites should one follow ? Fu Hsi and Shen-nung taught but did not punish; Huang-ti, Yao and Shun punished but were not angry; Wen-wang and Wu-wang both established laws in accordance with what was opportune and regulated rites according to practical requirements; as rites and laws were fixed in accordance with what was opportune, regulations and orders were all expedient, and weapons, armour, implements and equipment were all practical. Therefore, p.173 I say (601): «There is more than one way to govern the world and 
there is no necessity to imitate antiquity, in order to take appropriate measures for the state. » T'ang and $\mathrm{Wu}$ succeeded in attaining supremacy without following antiquity, and as for the downfall of Yin and Hsia - they were ruined without rites having been altered. Consequently, those who acted counter to antiquity do not necessarily deserve blame, nor do those who followed established rites merit much praise (602). Let Your Highness not hesitate.

p.174 Duke Hsiao said :

- Excellent ! I have heard it said that in poor country districts, much is thought strange, and that in village schools there are many debates (603). What the foolish laugh about, the wise are sad about; the joy of a madman ${ }_{\text {p.175 }}$ is the sorrow of a man of talent. One should, in one's plans, be directed by the needs of the times - I have no doubts about it.

Thereupon, in consequence, he issued the order to bring waste lands under cultivation (604). 


\section{Paragraph 2 An Order to Cultivate Waste Lands}

If there is no procrastination in the creating of order, depraved officials have no opportunity of gaining private profits at the expense of the people, nor will the hundred officials be in a condition to temporise and to shift responsibilities on to one another. If the hundred officials are not in a condition to temporise and shift responsibilities on to one another (605), then agriculture will know days of surplus; and if the depraved officials have no opportunity of gaining ${ }_{\text {p.176 }}$ private profits at the expense of the people, then agriculture will not be ruined. If agriculture is not ruined, but knows days of surplus, then it is certain waste lands will be brought under cultivation.

If taxes are levied according to the measure of grain, then the ruler will have system and consequently the people will have peace. If the ruler has system, he will be a man of his word, and being a man of his word, the officials will not dare to commit any depravity. If the people have peace, they are circumspect, and being circumspect, they are difficult to move. If the ruler is a man of his word and in consequence the officials dare not commit any depravity, and if the people are circumspect and consequently difficult to move, then there will be no criticism by inferiors of superiors, nor will the officials be regarded as obnoxious. If so, then the able-bodied will be strenuous in agriculture, without changing. If the able-bodied are so, then the youthful will learn it without resting, and when the youthful learn it without resting, it is certain waste lands will be brought under cultivation.

*3b If dignities are not conferred nor office given according to deviating standards (606), then the people will not prize learning ${ }_{\text {p.177 }}$ nor, besides, will they hold agriculture cheap. If they do not prize learning, they will be stupid, and being stupid, they will have no interest in outside things ; when they have no interest in outside things, the country will exert itself in agriculture and not neglect it, and when the people do not hold agriculture cheap, the country will be peaceful and free from peril. If the country is peaceful and free from peril, exerts itself in agriculture and does not neglect it, then it is certain waste lands will be brought under cultivation.

If salaries are liberal and consequently taxes numerous, then the large number of persons who live on others would mean ruin for agriculture; but if they are assessed according to the calculated number of persons who live on others and are made to work hard, then the wicked and licentious, idle and lazy will have nothing on which to live, and having nothing on which to live, they will take up agriculture ; when they take up agriculture, then it is certain waste lands will be brought under cultivation. 
Do not allow merchants to buy grain nor farmers to sell grain. If farmers may not sell their grain, then the lazy and inactive ones will exert themselves and be energetic; and, if merchants may not buy grain, then they have no particular joy over abundant years. Having no particular joy over abundant years, they do not make copious profit in years of famine, and making no copious profit, merchants ${ }_{\text {p.178 }}$ are fearful, and being fearful, they desire to turn farmers. If lazy and inactive farmers exert themselves and become energetic, and if merchants desire to turn farmers, then it is certain waste lands will be brought under cultivation.

*4a If music and fine clothing do not penetrate to all the districts, the people, when they are at work, will pay no attention to the latter, and when they are at rest, will not listen to the former. If, at rest, they do not listen to the one, their spirits will not become licentious; and if, at work, they pay no attention to the other, their minds are concentrated. If their minds are concentrated and their spirits not licentious, then it is certain waste lands will be brought under cultivation.

If it is impossible to hire servants, great prefects and heads of families are not supported and beloved sons cannot eat in laziness. If lazy people cannot be inactive, and hirelings do not find a livelihood, there will certainly be agriculture: when great prefects and heads of families are not supported, agricultural affairs will not suffer; and when beloved sons cannot eat in laziness and lazy people cannot be inactive, then the fields will not lie fallow. If agricultural affairs do not suffer and farmers increase their farming, then it is certain waste lands will be brought under cultivation.

If hostelries for the reception of travellers are abolished, criminals, agitators, conspirators and those who unsettle ${ }_{\text {p.179 }}$ the minds of the farmers will not travel and in consequence (607), hotel-keepers will have no means of subsistence. This being so (608), they will certainly become farmers, and so it is certain waste lands will be brought under cultivation.

If mountains and moors are brought into one hand, then the people who hate agriculture, the tardy and lazy and those who desire double profit, will have no means of subsistence. This being so, they will certainly become farmers, and so it is certain waste lands will be brought under cultivation.

If the prices of wine and meat are made high, and the taxes on them so heavy that they amount to ten times the cost of production, then merchants and retailers will be few, farmers $* 4 \mathrm{~b}$ will not be able to enjoy drinking-bouts, and officials will not overeat. If merchants and retailers are few, the ruler does not waste his grain; if the people are unable to enjoy drinking bouts, agriculture will not be neglected; if officials do not overeat, the affairs of the state will not be delayed and the prince will not err in his promotions. If the ruler does not waste the grain and if the people do not neglect agriculture, then it is certain waste lands will be brought under cultivation. 
If penalties are made heavy and relations (609) are involved in ${ }_{\text {p. } 180}$ the punishments, petty and irascible people will not quarrel, intractable and stubborn people will not litigate, slothful and lazy people will not idle, those who waste their substance will not thrive, and those of evil heart, given to flattery, will bring about no change. If these five kinds of people do not appear within the territory, then it is certain waste lands will be brought under cultivation.

\# If people are not allowed to change their abode unauthorisedly, then stupid and irregular farmers will have no means of subsistence and will certainly turn to agriculture. If the minds of stupid people, full of turbulent desires, have been concentrated, then it is certain farmers will be quiet ; if the farmers are quiet and stupid people (turn to agriculture), then it is certain waste lands will be brought under cultivation.

If orders are issued for the service of all younger sons (610), without exception, the service to last their lifetime, and no high palaces to be built for them, and if orders are given to the grain-measuring officials to weigh out their grain allowance evenly, and if on the one hand they are not used for menial services, but on the other hand they do not necessarily $*_{5}$ abtain high office, then the younger sons will not be idlers, ${ }_{\text {. } 181}$ and (this being so) they will certainly turn to agriculture ; and if that is the case, then it is certain waste lands will be brought under cultivation.

If the Ministers of State and the Great Officers are not allowed to occupy themselves with extensive learning, brilliant discussions and idle living, and if they are not allowed to reside, or to travel about, in the various districts, then the farmers will have no opportunity to hear of changes or see different places. This being so, clever farmers will have no opportunity to discard old ways, and stupid farmers will not become clever, nor will they become fond of study. If stupid farmers do not become clever nor fond of study, they will apply themselves energetically to agriculture ; and if clever farmers do not discard old ways, then it is certain waste lands will be brought under cultivation.

Women should not be permitted on the market-place of the army, but orders to be there should be given to merchants (611). Men should be commanded to provide themselves with cuirass and arms, to make the army appear in fine condition. Also if heed is given that there can be no private transport of grain on the army market-place, then there will be no opportunity to hatch corrupt schemes. If those who transport grain ${ }_{\text {p. } 182}$ dishonestly, cannot, from selfish motives, be negligent, frivolous and lazy people will not loiter about the army market-place; and if those who steal grain have no opportunity of selling, and those who send grain can make no private profit, and if frivolous and lazy people do not loiter about the army market-place, then farmers will not be $* 5$ b licentious, (if they are not licentious) the government's grain need not be resorted to, and (this being the case) it is certain waste lands will be brought under cultivation. 
If the administration of all the districts is of one pattern then (people) will be obedient ; eccentric ones will not be able to be ostentatious, and successive officials will not dare to make changes ; and if they act wrongly and abolish (the existing administration), it will be impossible to keep their actions hidden. If their mistaken actions do not remain hidden, then among the officials there will be no depraved men; and if eccentric people can not be ostentatious, and successive officials make no changes, then the official appurtenances will be few and the people will not be harassed. If the officials are not depraved, the people will not seek amusement, and if the people do not seek amusement, their occupations will not suffer ; if official appurtenances are few, taxes will not be troublesome, ${ }_{\mathrm{p} .183}$ and if the people are not harassed, farming will know days of plenty; if farming knows days of plenty, taxes are not troublesome and occupations do not suffer, then it is certain waste lands will be brought under cultivation.

If the tolls at the barriers and on the market are made heavy, then the farmers will hate the merchants, and the merchants will be full of doubt and be unenterprising. If the farmers hate the merchants and the merchants are full of doubt and unenterprising, then it is certain waste lands will be brought under cultivation.

If merchants are made to serve according to their full complement, and if their multitudes of servants and crowds of followers are obliged to be registered, then farmers will have leisure and merchants will be harassed; farmers having leisure, fertile land will not lie fallow; merchants being harassed, the custom of sending presents backwards and forwards will not pervade the various districts. (If fertile land does not lie fallow) farmers will not suffer from famines, (and if the custom of sending presents backwards and forwards does not pervade the various districts), p.184 there will be no ostentatious conduct. If farmers do not $*_{6 a}$ suffer from famines and there is no ostentatious conduct, then public activities will be pursued with energy, and in the sphere of private activities there will be no fallow fields. (This being so), then agricultural affairs will certainly excel, and this being the case, it is certain waste lands will be brought under cultivation.

If in transporting grain for official use, carters are prohibited from plying for hire and returning with private cargo (611a), and if measures are taken to ensure the registration of carts, oxen, carriages and baggage waggons, the expedition backward and forward will thus be quick and then this occupation will not harm agriculture ; agriculture not being harmed, it is certain waste lands will be brought under cultivation.

If it is not permitted to petition officials on behalf of wrongdoers, nor to provide them with food, then criminal people will have no patrons; having no patrons, crimes will not be encouraged; crimes not being encouraged, criminal people will have no hold ; criminal people having no hold, farmers will not suffer, and if farmers do not suffer, it is certain waste lands will be brought under cultivation. 


\section{Paragraph 3 \\ Agriculture and War}

p.185 The means whereby a ruler of men encourages the people are office and rank; the means whereby a country is made prosperous are agriculture and war. Now those who seek office and rank, never do so by means of agriculture and war, but by artful words and empty doctrines. That is called "wearying the people". *6b The country of those who weary their people will certainly have no strength, and the country of those who have no strength will certainly be dismembered. Those who are capable in organizing a country teach the people that office and rank can only be acquired through one opening, and thus, there being no rank without office, the state will do away with fine speaking, with the result that the people will be simple; being simple, they will not be licentious. The people, seeing that the highest benefit comes only through one opening, will strive for concentration (611b), and having concentration, will not be negligent in their occupations. When the people are not negligent in their occupations, they will have much strength, and when they have much strength the state will be powerful.

But now the people within the territory all say that by avoiding agriculture and war, office and rank may be acquired, with the result that eminent men all change their occupations, ${ }_{\text {p. } 186}$ to apply themselves to the study of the Odes and History and to follow improper standards (612); on the one hand, they obtain prominence, and on the other, they acquire office and rank. Insignificant individuals (613) will occupy themselves with trade and will practise arts and crafts, all in order to avoid agriculture and war, thus preparing a dangerous condition for the state (614). Where the people are given to such teachings, it is certain that such a country will be dismembered.

\# The way to organize a country well is, even though the granaries are filled, not to be negligent in agriculture, and even though the country is large and its population numerous, to have no licence of speech. (This being so), the people will be simple and have concentration; the people being simple and having concentration, then office arid rank cannot be obtained by artfulness. If these cannot be obtained by $* 7$ a artfulness, then wickedness will not originate ; and if wickedness does not originate, the ruler will not be suspicious.

p.187 \# But now the people within the territory, and those who hold office and rank, see that it is possible to obtain, from the court, office and rank by means of artful speech and sophistry. Therefore, there is no permanency in office and rank, with the result that at court they deceive their ruler and, retiring from court, they think of nothing but of how to realize their selfish interests and thus sell power (615) to their inferiors. Now deceiving the ruler and being concerned for their own interests is not to the advantage of the state, but those who thus act, do so for the sake of rank and emolument; selling 
power to inferiors is not proper for a loyal minister, but those who thus act do so for the sake of insignificant presents.

Consequently all the lower officials, who hope for promotion, say :

- If we send many presents, we may obtain the higher office which we desire.

They say too :

- To strive for promotion, without serving superiors with presents, is like setting a cat as bait for a rat (616) — it is absolutely hopeless. To strive for promotion by serving superiors with sincerity is like wishing to climb a crooked tree by holding on to a broken rope - it is even more hopeless. If, to attain promotion, these two methods are out of the question, what else can we do, in striving for it, but bring the masses below us into action and obtain presents, for the purpose of serving our superiors $(\underline{617)} ? * 7 \mathrm{~b}$

p.188 The people say : We till diligently, first to fill the public granaries, and then to keep the rest for the nourishment of our parents ; for the sake of our superiors we forget our love of life, and fight for the honour of the ruler and for the peace of the country. But if the granaries are empty, the ruler debased and the family poor, then it is best to seek office. Let us then combine relatives and friends and think of other plans. Eminent men will apply themselves to the study of the Odes and History, and pursue these improper standards (618); insignificant individuals will occupy themselves with trade, and practise arts and crafts, all in order to avoid agriculture and war (619). Where the people are given to such teachings, how can the grain be anything but scarce, and the soldiers anything but weak?

The way to administer a country well, is for the law for the officials to be clear ; therefore one does not rely on intelligent and thoughtful men. The ruler makes the people singleminded, and therefore they will not scheme for selfish profit. Then the strength of the country will be consolidated. A country where the strength has been consolidated, is powerful, but a country that loves talking is dismembered. Therefore is it said :

«If there are a thousand people engaged in agriculture and war, and only one in the Odes and History, ${ }_{\text {p.189 }}$ and clever sophistry, then those thousand will all be remiss in agriculture and war ; $*_{8 \mathrm{a}}$ if there are a hundred people engaged in agriculture and war and only one in the arts and crafts, then those hundred will all be remiss in agriculture and war (620).

The country depends on agriculture and war for its peace, and likewise the ruler, for his honour. Indeed, if the people are not engaged in agriculture and war, it means that the ruler loves words and that the officials have lost consistency of conduct. If there is consistency of conduct in officials, the country is well-governed (621); and if single-mindedness is striven after, the 
country is rich ; to have the country both rich and well governed is the way to attain supremacy. Therefore is it said :

«The way to supremacy is no other than by creating single-mindedness !

However, nowadays, the ruler, in his appointments, takes into consideration talent and ability and cleverness and intelligence, and thus clever and intelligent men watch for the likes and dislikes of the ruler, so that officials are caused to transact their business in a way which is adapted to the ruler's mind. As a result there is no consistency of conduct in the officials, the state is in disorder and there is no concentration. Sophists (are honoured) (622) and there is no law. Under such circumstances, how can the people's affairs p.190 be otherwise than many and how can the land be otherwise than fallow ?

\# If, in a country, there are the following ten things : odes and history, rites and music, virtue and the cultivation thereof, benevolence and integrity, sophistry and intelligence (623), then the ruler has no one whom he can employ for defence and warfare. If a country is governed by means of these ten things, it will be dismembered as soon as an enemy approaches, and even if no enemy approaches, it will be poor. But if a country banishes these ten things, enemies will not dare to approach, and even if they should, they would be driven back. When it mobilizes its army and attacks, it will gain victories ; when it holds the army in reserve and does not attack, it will be rich. A country that loves strength makes assaults with what is difficult, and thus it will be successful. A country that loves sophistry makes assaults with what is easy, and thus it will be in danger (624).

Therefore sages and intelligent princes are what they are, not because they are able to go to the bottom of all things, but because they understand what is essential in all things. Therefore the secret of their administration of the country lies in nothing else than in their examination of what is essential. But now, those who run a state for the most part overlook what is essential, and the discussions at court, on government, are confused, and efforts are made to displace each other in them; thus the prince is dazed by talk, officials p.191 confused by words, and the people become lazy and will not farm. The result is that all the people within the territory change and become fond of sophistry, take pleasure in study, pursue trade, practise arts and crafts, and shun agriculture and war ; and so in this manner (the ruin of the country) will not be far off. When the country has trouble, then because studious people hate law, and merchants are clever in bartering and artisans are useless, the state will be easily destroyed.

Indeed, if farmers are few, and those who live idly on others are many, then the state will be poor and in a dangerous condition. Now, for example, if various kinds of caterpillars (625), which are born in spring and die in autumn, appear only once, $*_{9 \mathrm{a}}$ the result is that the people have no food for many years. Now, if one man tills and a hundred live on him, it means that they are like a great visitation of caterpillars. Though there may be a bundle of the Odes and 
History in every hamlet and a copy in every family, yet it is useless for good government, and it is not a method whereby this condition of things may be reversed. Therefore the ancient kings made people turn back to agriculture and war. For this reason is it said :

«Where a hundred men farm and one is idle, the state will attain supremacy; where ten men farm and one is idle, the state will be strong; where half farms and half is idle, the ${ }_{\text {p.192 }}$ state will be in peril (626).

That is why those who govern the country well, wish the people to take to agriculture. If the country does not take to agriculture, then in its quarrels over authority with the various feudal lords, it will not be able to maintain itself, because the strength of the multitude will not be sufficient. Therefore the feudal lords vex its weakness and make use of its state of decadence; and if the territory is invaded and dismembered, without the country being stirred to action, it will be past saving.

A sage knows what is essential in administrating a country, and so he induces the people to devote their attention to agriculture. If their attention is devoted to agriculture, then they will be simple, and being simple, they may be made correct. Being perplexed, it will be easy to direct them (627); being trustworthy, they may be used for defence and warfare. Being single-minded, opportunities of deceit will be few, and they will attach importance to their homes $(\underline{628)}$. Being single-minded, their careers may be made dependent on rewards and penalties ; $* 9 \mathrm{~b}$ being single-minded, they may be used abroad.

Indeed, the people will love their ruler and obey his ${ }_{\text {p.193 }}$ commandments even to death (629), if they are engaged in farming, morning and evening; but they will be of no use if they see that glib-tongued, itinerant scholars succeed in being honoured in serving the prince, that merchants succeed in enriching their families, and that artisans have plenty to live upon. If the people see both the comfort and advantage of these three walks of life, then they will indubitably shun agriculture; shunning agriculture, they will care little for their homes ; caring little for their homes, they will certainly not fight and defend these for the ruler's sake (630).

Generally speaking, in administrating a country, the trouble is when the people are scattered and when it is impossible to consolidate them. That is why a sage tries to bring about uniformity and consolidation. A state where uniformity of purpose has been established for one year, will be strong for ten years ; where uniformity of purpose has been established for ten years, it will be strong for a hundred years, where uniformity of purpose has been established for a hundred years, ${ }_{\text {p.194 }}$ it will be strong for a thousand years ; and a state which has been strong for a thousand years will attain supremacy (631).

An ordinary prince cultivates the system of rewards and penalties in order to support his teaching of uniformity of purpose, and in this way his teaching has permanency and his administration is successfully established. But he who 
attains supremacy, succeeds in regulating those things which are most essential for the people, and therefore, even without $* 10$ a the need of rewards and gifts, the people will love their ruler; without the need of ranks and emoluments, the people will follow their avocations; without the need of penalties, the people will do their duty to the death.

\# When a country is in peril and the ruler in anxiety, it is of no avail to the settling of this danger for professional talkers to form battalions (632). The reason why a country is in danger and its ruler in anxiety lies in some strong enemy or in another big state. Now if a prince is unable to vanquish that strong enemy or to destroy that big state, he improves his defences, makes the best use of the topographical conditions, consolidates the strength of the people and thus meets the foreign attack. After this the danger may be averted and supremacy yet attained. That is why an intelligent prince, in improving the administration, strives for uniformity, removes those who are of no use, restrains volatile scholars and those of frivolous pursuits, and makes them all uniformly into farmers. Thereafter the reigning dynasty may become rich and the people's strength may be consolidated.

p.195 Nowadays, the rulers of the world are all anxious over the perilous condition of their countries and the weakness of their armies, and they listen at all costs to the professional talkers : but though these may form battalions, talk profusely and employ beautiful expressions, it is of no practical use. When a ruler loves their sophistry and does not seek for their practical value, then the professional talkers have it all their own way, expound their crooked sophistries in the streets, their various groups become great crowds, and the people, seeing that they succeed in captivating kings, dukes and great men, all imitate them (633). $* 10 \mathrm{~b}$ Now, if men form parties, the arguments and dissensions in the country will be of confusing diversity ; the lower classes will be amused and the great men will enjoy it, with the result that amongst such a people farmers will be few and those who, in idleness, live on others will be many. These latter being numerous, farmers will be in a perilous position, and this being so, land will be left lying fallow. If study becomes popular, people will abandon agriculture and occupy themselves with debates, high-sounding words and discussions on false premises; abandoning agriculture, they will live on others in idleness, and seek to surpass one another with words. Thus the people will become estranged from the ruler, and there will be crowds of disloyal subjects. This is a doctrine which leads to the impoverishment of the state and to the weakening of the army. Indeed, if a country employs people for their talking, then the people will not be nurtured in agriculture; so it is p.196 only an intelligent prince who understands that by fondness for words one cannot strengthen the army nor open up the land. Only when a sage rules the country will he strive for singleness of purpose and for the consolidation of the people in agriculture, and for that alone. 


\section{Paragraph 4 The Elimination of Strength}

To remove the strong by means of a strong people brings weakness; to remove the strong by means of a weak people brings strength (634). If the country practises virtue (635), criminals are many. If the country is rich, but is administered as if it $* 11$ a were poor, then it is said to be doubly rich, and the doubly rich are strong. If the country is poor, but is administered as if it were rich, it is said to be doubly poor, and the doubly poor are weak. If its army accomplishes what the enemy dares not accomplish, (a country) is strong; if affairs are undertaken which the enemy is ashamed to perform, (a country) profits (636). A ruler values many changes, but the country ${ }_{\text {p.197 }}$ values few changes (637). If the country has few products it will be dismembered, but if it has many products it will be strong. A country of a thousand chariots that keeps only one outlet for its products will flourish, but if it keeps ten outlets it will be dismembered.

If in war its army is efficient, a country will be strong; but if fighting is disorderly and the army unwilling, the country will be dismembered.

\# Farming, trade and office are the three permanent functions (638) in a state (639), and these three functions give rise to six parasitic functions (640), which are called : care for old age (641), living on others, beauty, love, ambition and virtuous conduct. If these six parasites find an attachment, there will be dismemberment (642). The three functions are attached ${ }_{\mathrm{p} .198}$ to three different men, but these six functions may attach themselves to one man (643).

To abolish law by means of the law means strength; to establish law by means of the law means dismemberment. If officials are permanent, law is abolished; but if officials are often transferred, laws are established. In administering a great country, it becomes small; in administering a small country, it becomes great (644). If the people are made strong, the army will be doubly diminished; if the people are made weak, the army will be doubly strengthened (645).

Indeed, to attack the strong with a strong people spells ruin; to attack the strong with a weak people means ${ }_{\text {p. } 199}$ the attainment of supremacy. \# If the country is strong and war $* 11 \mathrm{~b}$ is not waged, the poison will be carried into the territory; rites and music and the parasitic functions will arise, and dismemberment will be inevitable. But if the country (being strong) thereupon wages war, the poison will be carried to the enemy, and not suffering from rites and music and the parasitic functions, it will be strong. If those who exert themselves are promoted, and men of merit are employed in office, the country will be strong; but if the parasitic functions arise, dismemberment will be inevitable. \# If farmers are few and merchants numerous, men in high 
positions will be poor, merchants will be poor and farmers will be poor; these three functions all being poor, dismemberment is inevitable.

If in a country there are the following ten evils : rites, music, odes, history, virtue, moral culture, filial piety, brotherly duty, integrity and sophistry, the ruler cannot make the people fight and dismemberment is inevitable ; and this brings extinction in its train (646). If the country has not these ten things and the ruler can make the people fight, he will be so prosperous that he will attain supremacy. $A_{\text {p.200 }}$ country where the virtuous govern the wicked, will suffer from disorder, so that it will be dismembered ; but a country where the wicked govern the virtuous, will be orderly, so that it will become strong (647).

\# A country which is administered by the aid of odes, history, rites, music, filial piety, brotherly duty, virtue and moral culture, will, as soon as the enemy approaches, be dismembered; if he does not approach, the country will be poor. But if a country is administered without these eight (648), the enemy dares not approach, and even if he should, he would certainly be driven off when it mobilizes its army and attacks, it will capture its objective, and having captured it, will be able to hold it; when it holds its army in reserve, and makes no attack, it will be rich. A country that loves force is said to attack with what is difficult; a country that ${ }_{* 12 \mathrm{a}}$ loves words is said to attack with what is easy. A country that attacks with what is difficult will gain ten points for every one point that it undertakes, whereas a country that attacks with what is easy will lose a hundred men for every ten that it marches out (649).

\# If penalties are made heavy and rewards light, the ruler loves his people and they will die for him ; but if rewards are made heavy and penalties light, the ruler does not love his ${ }_{\text {p.201 }}$ people, nor will they die for him. When, in a prosperous country, penalties are applied, the people will reap profit and at the same time stand in awe; when rewards are applied, the people will reap profit and at the same time have love (650).

A country that has no strength and that practises knowledge and y cleverness, will certainly perish $(651)$; but a fearful people, stimulated by penalties, will become brave, and a brave people, encouraged by rewards, will fight to the death. If fearful people become brave and brave people fight to the death, (the country will have no match) ; having no match, it will be strong, and being strong it will attain supremacy (652).

\# If the poor are encouraged by rewards, they will become rich, and if penalties are applied to the rich, they will become poor (653). When in administrating a country one succeeds in making the poor rich and the rich poor, then the country will have much strength (654), and this being the case, it will attain supremacy.

In a country that has supremacy, there are nine penalties ${ }_{\text {p.202 }}$ as against one reward (655); in a strong country, there will be seven penalties to three rewards, and in a dismembered country, there will be five penalties to five rewards. 
A country where uniformity of purpose has been established for one year, will be strong for ten years ; where uniformity of purpose has been established for ten years, it will be strong for a hundred years; where uniformity of purpose has been $*_{12 b}$ established for a hundred years, it will be strong for a thousand years ; and a country that has been strong for a thousand years will attain supremacy ( $\underline{656)}$.

One who has prestige captures ten by means of one, and grasps concrete things by means of the very sound of his name. Therefore he who succeeds in having prestige, attains supremacy.

A country which knows how to produce strength but not how to reduce it (657), may be said to be a country that attacks itself (658), and it is certain that it will be dismembered ; but a country that knows how to produce strength and how to reduce it may be said to be one that attacks the enemy, and it is certain that it will become strong (659). Therefore, the combating of the parasites, the curtailing of its energies ${ }_{\text {p.203 }}$ and the attacking of its enemy (660) - if a country employs two of these methods and sets aside only one, it will be strong; but that which employs all three methods will have so much prestige that it will attain supremacy.

A country where ten hamlets are the smallest unit for judgments, will be weak ; a country where nine hamlets (661) are the smallest unit for judgments, will be strong. He who can create order in one day will attain supremacy; he who creates order in a night will be strong, and he who procrastinates in creating order will have his state dismembered (662).

\# If the whole population is registered at birth and erased (663) at death, there would be no people who would escape agriculture, and in the fields there would be no fallow land. Thus the country would be rich, and being rich it would be strong. If penalties are removed by means of penalties, the country will enjoy order, but if penalties are set up by means of penalties, the country will be in disorder. Therefore is it said :

«In applying penalties, punish heavily the light offences.

If punishments are abolished, affairs will succeed and the country will be strong. But if heavy offences are punished heavily and light offences lightly, penalties will appear, trouble will arise and such a state will be dismembered (664). p.204 Punishment produces force, force produces strength, strength produces awe, awe produces kindness. Kindness has its ${ }_{* 13 a}$ origin in force (665).

In exerting force one should fight with complete courage, and in fighting, plan with complete wisdom (666).

\# The appearance of gold means the disappearance of grain, and the appearance of grain means the disappearance of gold. If products are cheap those who occupy themselves with agriculture being many, and buyers being few - farmers will be in hard straits and wickedness will be encouraged, so 
that the army will be weak and the state will certainly be dismembered and come to extinction.

For every ounce of gold appearing within its borders, twelve piculs of grain will disappear abroad ; but for every twelve piculs of grain appearing within its borders, one ounce of gold will disappear abroad (667). If a country favours the appearance of gold within its borders, then gold and grain will both disappear, granary and treasury will both be empty, and the state will be weak. But if a country favours the appearance of grain within its borders, then gold and grain will both appear, granary and treasury will both be filled, and the state will be strong.

p.205 A strong country knows thirteen figures (668): the number of granaries within its borders, the number of able-bodied men and of women, the number of old and of weak people, the number of officials and of officers, the number of those making a livelihood by talking, the number of useful people (669), the number of horses and of oxen, the quantity of fodder and of straw. If he who wishes to make his country strong, $* 13 \mathrm{~b}$ does not know these thirteen figures, though his geographical position may be favourable and the population numerous, his state will become weaker and weaker, until it is dismembered.

A country where there are no dissatisfied people is called a strong country. When the army is mobilized for an offensive, rank is given according to military merit, and reliance being placed upon the military, victory is certain. When the army is in reserve and agriculture is pursued, rank is given according to the production of grain, and reliance being placed upon farming, the country will be rich. If in military enterprises the enemy is conquered and if, when the army is in reserve, the country becomes rich, then it attains supremacy. 


\title{
CHAPTER 2
}

\section{Paragraph 5 \\ Discussion about the People (670)}

\begin{abstract}
p. $206 * 1$ S Sophistry and cleverness are an aid to lawlessness ; rites and music are symptoms of dissipations and licence; kindness and benevolence are the foster-mother of transgressions ; employment and promotion are opportunities for the rapacity of the wicked (670). If lawlessness is aided, it becomes current ; if there are symptoms of dissipation and licence, they will become the practice ; if there is a foster-mother for transgressions, they will arise ; if there are opportunities for the rapacity of the wicked, they will never cease. If these eight things (671) come together, the people will be stronger than the government (672); but if these eight things are non-existent in a ${ }_{\text {p.207 }}$ state, the government will be stronger than the people. If the people are stronger than the government, the state is weak; if the government is stronger than the people, the army is strong. For if these eight things exist, the ruler has no one to use for defence and war, with the result that the state will be dismembered and will come to ruin ; but if there are not these eight things, the ruler has the wherewithal for defence and war, with the result that the state will flourish and attain supremacy.
\end{abstract}

\# If virtuous officials are employed, the people will love their own relatives, but if wicked officials are employed, the people will love the statutes (673). To agree with, and to respond to, others is what the virtuous do ; to differ from, and to spy upon, others is what the wicked do. If the virtuous are placed in positions of evidence, transgressions will remain hidden; but if the wicked are employed, crimes will be punished. $* 1 \mathrm{~b}$ In the former case the people will be stronger than the law; in the latter, the law will be stronger than the people. If the people are stronger than the law, there is lawlessness in the state, but if the law is stronger than the people, the army will be strong. Therefore is it said :

«Governing through good people leads to lawlessness and dismemberment; governing through wicked people leads to order and strength (674).

A country which attacks with what is difficult will gain ten points for every one that it undertakes; a country which ${ }_{\text {p.208 }}$ attacks with what is easy will lose a hundred men for every ten that it marches out. A country that loves force is said to attack with what is difficult; a country that loves words is said to attack with what is easy (675). People find it easy to talk, but difficult to serve. A state where, when the laws of the country are applied, conditions for the 
people are hard and by military service those conditions are eased, so that it attacks with force, will gain ten points for every one it undertakes; but a state where, when the laws of the country are applied, conditions for the people are easy, and by military service those conditions are made hard, so that it attacks with words, will lose a hundred men for every ten that it marches out.

\# The fact that penalties are heavy makes rank the more honourable, and the fact that rewards are light makes punishments the more awe-inspiring. If rank is honoured, the ruler loves the people, and if punishments are so awe-inspiring, the people still die for their ruler. Therefore, in a prosperous country, the people profit by the application of penalties, and by the distribution of rewards the ruler will gain credit (676).

If the law goes into details, the punishments will be multitudinous ; if the laws are multitudinous, punishments will be scarce (677).

p.209 \# If, from a condition of rule and order, the people become lawless, and if one tries to rule this lawlessness, it will only increase ; therefore, it should be ruled while it is still in a state of rule and order, then there will be true rule and order; if it is ruled while it is in a state of lawlessness, lawlessness will remain (678).

It is the nature of the people to be orderly, but it is circumstances that cause disorder. \# $*_{2 \mathrm{a}}$ Therefore, in the application of punishments, light offences should be regarded as serious ; if light offences do not occur, serious ones have no chance of coming. This is said to be "ruling the people while in a state of law and order".

If in the application of punishments, serious offences are regarded as serious, and light offences as light, light offences will not cease and in consequence, there will be no means of stopping the serious ones. This is said to be "ruling the people while in a state of lawlessness". So, if light offences are regarded as serious, punishments will be abolished, affairs will succeed and the country will be strong; but if serious offences are regarded as serious and light ones as light, then punishments will appear ; moreover, trouble will arise and the country will be dismembered (679).

If the people are brave, they should be rewarded with what ${ }_{\text {p.210 }}$ they desire ; if they are timorous, they should be put to death in a manner they hate. In this way timorous people, being incited by punishments, will become brave ; and the brave, being encouraged by rewards, will fight to the death. If timorous people become brave, and the brave fight to the death, the country having no equal will certainly attain supremacy (680).

If the people are poor, they are weak ; if the country is rich, they are licentious, and consequently there will be the parasites (681); the parasites will bring weakness. Therefore, the poor should be benefited with rewards, so that they become rich, and the rich should be injured by punishments, so that they become poor (682). The important thing in undertaking the administration of a country is to make the rich poor, and the poor rich. $*_{2 b}$ If that is effected, the 
country will be strong (683). If the three classes of people (684) do not suffer from the parasites, the country will be strong for a long time to come, and such a country, free of parasites, may be certain of supremacy.

\# Punishment produces force, force produces strength, strength produces awe, awe produces virtue. Virtue has its origin in punishments (685). For the more punishments there are, the more valued are rewards, and the fewer rewards there are, the more heed is paid to punishments, by virtue of the ${ }_{\text {p. }} 211$ fact that people have desires and dislikes. What they desire are the six kinds of licence (686), and what they dislike are the four kinds of hardship (687). Indulgence in these six kinds of licence will make the country weak; but the practice of these four kinds of hardship will make the army strong. \# Therefore, in a country which has attained supremacy, punishments are applied in nine cases and rewards in one (688). If in nine cases, punishments are applied, the six kinds of licence will stop, and if in one case rewards are given, the four kinds of hardship will be practised. If the six kinds of licence are stopped, the country will be without crime ; and if the four kinds of hardship are practised, the army will be without equal.

The things which the people desire are innumerable, but that from which they benefit is one and the same thing. \# Unless the people be made one, there is no way to make them attain their desire. Therefore, they are unified; as a result of this unification, their strength is consolidated, and in consequence of this consolidation, they are strong ; if, being strong, they are made use of, they are doubly strong. Therefore, a country that knows how to produce strength and how to reduce it is said to be one that attacks the enemy, and is sure to become strong. It bars all private roads for gratifying their ambition, and opens only one gate through $* 3$ a which they can attain their desire; thus, without doubt, ${ }_{\text {p.212 }}$ it can make the people first do what they hate, in order thereafter, to reach what they desire; and so their strength will be great. If their strength is great, but not made use of, ambition is gratified; and this being so, there will be private interest and in consequence there will be weakness.

Therefore, a country that knows how to produce strength, but not how to reduce it, is said to be one that attacks itself, and it is certain to be dismembered (689). So it is said that if a state has attained supremacy, it does not reserve its strength and the family does not hoard grain. That the state does not reserve its strength means that its subjects are used, and that the family does not hoard grain means that the superiors keep it in the granaries.

If the order of the country depends on the judgments of the family, it attains supremacy; if it depends on the judgments of the officials, it becomes only strong; if it depends on the judgments of the prince, it becomes weak. If light offences are heavily punished, punishments will disappear ; if officials are permanent, there is orderly administration (690). The necessary guarantee for restricting the use of punishments is that promises of rewards are kept (691). If they make it their habit to denounce all crimes, then the people make the 
judgments in their own minds; and if, when the ruler gives his orders, the people know how to respond, so that the means ${ }_{\text {p.213 }}$ for enforcing the law (692) are really manufactured in the families and merely applied by the officials (693), then the judgments over affairs rest with the family. \# Therefore, in the case of one who attains supremacy, judgments with regard to punishments and rewards rest with the people's own minds, and those with regard to the application of the means for enforcing the law rest with the family. If there is a clear law, people will agree with one another; if there is an obscure law, people will differ from one another. If they agree, things run smoothly, but if they differ, things are hampered; in the former case, there is order, in the latter, disorder. If there is order, it is the families that make judgments ; if there is disorder, it is the prince who makes judgments.

Those who administer a country deem it important that inferiors should give judgments ; *3b therefore, when ten hamlets are the unit for making judgments, there will be weakness; whereas when five hamlets are the unit for making judgments, there will be strength. If it is the family that gives judgments, there will be abundance. Therefore, of such a country it is said :

« He who creates order in one day will attain supremacy.

If it is the officials who give judgments, the order will not be sufficient; therefore of such a country it is said :

« He who creates order in a night will ${ }_{\text {p. } 214}$ merely be strong.

But if it is the prince who gives judgments, there will be disorder ; therefore of such a country it is said :

«He who procrastinates in creating order will be dismembered (694).

Therefore in a country that has the true way, order does not depend on the prince, and the people do not merely follow the officials. 


\section{Paragraph 6 The Calculation of Land}

The disasters of the rulers of the world, generally, come from their not measuring their strength in the use of armies, and from their not measuring their territory in managing the grass-fields and uncultivated lands. Therefore, sometimes the territory is narrow and the population numerous, so that the population exceeds the territory; or sometimes the territory is extensive, but the population sparse, so that the territory exceeds the population. If the population exceeds the territory, then one should pay attention to opening up new land; if the territory exceeds the population, then one should set about calling in colonists. By opening up new land, one effects increase ... (695) If the population exceeds the territory, then the achievements of the state will be few and the military strength small; if the territory exceeds p.215 the population, then the resources of mountains and moors will not be utilized. Now, to neglect natural resources and to pander to the people's dissipations is to fail in one's duty as a ruler, and when high and low act thus, then in spite of $\mathrm{a} * 4 \mathrm{a}$ large population, the army will be weak, and in spite of a big territory, its strength will be small.

In administering a state therefore, and in disposing of its territory, the correct rule of the former kings was to populate the mountains and forests with a tenth of the people, the marshes and moors with a tenth, the valleys, dales and streams with a tenth, cities, towns and highways with four tenths (696). In administering a state, therefore, and in dividing arable land, if a minimum of $500 \mathrm{mu}$ is sufficient to support one soldier, it is not making proper use of the land. But if a territory of 100 square $l i$ supports 10,000 soldiers for war as a minimum, then it shows that the cultivated land is sufficient to nourish its population, that cities, towns and highways are sufficient to accommodate their inhabitants, that mountains and forests, marshes and moors, valleys and dales, are sufficient to provide profit, and that marshes and moors, dykes and embankments are sufficient for grazing (697). Therefore, when the army marches out and grain is given them, there is still a surplus of riches; when the army is resting ${ }_{\text {p.216 }}$ and the people at work, the cattle are always sufficient. This is said to be the rule for making use of the land and for supporting soldiers. But nowadays, although the rulers of the world have territory of several thousand square $l i$, the produce is not sufficient to support the soldiers and to fill the granaries, and the army is equalled by the neighbours. I regret this state of affairs, therefore, on behalf of the ruler. Indeed, having a large territory and not cultivating it is like $* 4 \mathrm{~b}$ having no territory ; having a numerous population, but not employing it, is like having no population. 
Therefore, the statistical method of administering a country is to give attention to the cultivation of the grass lands; the way to employ the soldiers is to pay attention to making uniform rewards. If private gain has been debarred in outside occupations, then the people will be concerned with keeping to agriculture. If they keep to agriculture, they will be simple, and if they are simple, they fear the law. If private rewards are forbidden to those below, then the people will take the offensive forcibly against the enemy, and by taking the offensive (698) against him, they conquer. How does one know that it will be thus ? Well, the natural disposition of the people is that if they are simple, they will produce hard work and will exert their strength easily. If they are poor, they will develop common sense and give due consideration to what is profitable. If they exert their strength easily, they ${ }_{\text {p. } 217}$ will think lightly of death and will enjoy employment in warfare. If they give due consideration to what is profitable, they will fear punishment and will easily suffer hardship ; if they easily suffer hardship, then the capacity of the soil will be developed to the full ; if they enjoy employment in warfare, military strength will be developed to the utmost.

Now, if he who administers a country is able to develop the capacity of the soil to the full and to cause the people to fight to the death, then fame and profit will jointly accrue.

It is the nature of the people, when they are hungry, to strive for food; when they are tired, to strive for rest; when they suffer hardship, to seek enjoyment ; when they are in a state of humiliation, to strive for honour. Such is the natural disposition of the people. If the people strive for gain, then they lose the rules of polite behaviour ; if they strive for fame, they lose the eternal principles of human nature. How can we conclude that it is so ? Well, take now $*_{5 \mathrm{a}}$ robbers and thieves ; they infringe the interdicts of the prince, above, and below they fail in the polite behaviour of subject and son. Therefore, though their reputations are dishonoured and their persons endangered, yet because of the profit they do not desist. Above these are the scholars of the world; their clothes do not warm their skins, their food does not fill their stomachs, they travail their thoughts, fatigue their four limbs and suffer in their five internal organs, and yet they go on increasing their activity. This is not prompted by the ${ }_{\mathrm{p} .218}$ eternal principles of human nature, but for the sake of fame. Therefore is it said :

«Where fame and profit meet, that is the way the people will follow.

If the ruler controls the handle of fame and profit, so as to be able to acquire success and fame, it is due to statistical method. A sage examines the weights, in order to control the handle of the scales; he examines the statistical method in order to direct the people. Statistics is the true method of ministers and rulers and the essential of a state (699). For never yet has it happened but that a state of a thousand chariots that neglected statistics has come into a perilous 
position, and ministers and rulers that neglected method have experienced disorder.

Nowadays, the rulers of the world wish to open up their territory and to govern the population, without examining the statistics, and ministers desire to fulfil their task without establishing a method. Therefore, the country has a disobedient population and the ruler refractory ministers.

p. $219 * 5$ b A sage, therefore, in organizing a country causes the people in home affairs to adhere to agriculture, and in foreign affairs to scheme for war. Now, agriculture makes the people suffer hardships, and war makes them run dangers, and the means whereby they can be led to encounter hardships and to perform actions that expose them to danger, is calculation. For the people, when alive, scheme for profit, and when in danger of death, are anxious for fame.

It is necessary to examine whence fame and profit spring. If the profit comes from the soil, then people will use their strength to the full ; if fame results from war, then they will fight to the death. Now if, at home, the people are directed to use their strength to the full, then the fields will not lie fallow ; and if, abroad, they are directed to fight to the death, then they conquer their enemies. If enemies are conquered and at the same time fields do not lie fallow, then without moving, the result will be obtained of having both wealth and strength.

But nowadays, it is not thus; that which the rulers of the world are particularly concerned about is not at all that of which the state stands in urgent need. In their persons, they have the conduct of Yao and Shun, but in their results they do not even approximate those of T'ang or Wu. The mistake lies with the handle which they hold. Let me be permitted to set forth their error.

In administrating the country, they reject power (700) and indulge in talking. By talking (701), their persons become ${ }_{\text {p.220 }}$ cultivated, but their success is small. So scholars, full of empty talk about the Odes and the Book of History, are held in esteem, so that people become restless and think lightly of their prince; scholars who are out of office are held in esteem, so that people become estranged and criticize their superiors ; $*_{6 \mathrm{a}}$ braves are held in esteem, so that the people become quarrelsome and think lightly of prohibitions; artisans are used, so that the people become volatile and easily move their places of abode ; merchants and retailers, though leisurely, yet make profit, so that the people follow their example and discuss their superiors. Therefore, if these five kinds of people are used in the state, then fields will lie fallow and the army will be weak. The capital of scholars who are full of empty words lies in their mouths ; that of scholars who are out of office lies in their ideas ; that of braves in their valour, that of artisans in their hands, and that of merchants and retailers in their bodies (702). Thus, they can carry their personal capital round to any house on earth (703). If, for the people's capital, importance is attached to physical talents, and for their habitat they are 
dependent on the outside world, then those who carry considerable capital will become temporary sojourners (704). This would have caused difficulties even to Yao and Shun ; therefore, T'ang and $\mathrm{Wu}{ }_{\text {p.221 }}$ prohibited it, with the result that their success was established and their fame made.

A sage cannot, with what the world thinks easy, overcome that which it thinks difficult, but he must, by means of what it thinks difficult, overcome that which it thinks easy. So, for example, if the people are stupid, he can overcome it by means of knowledge; if the world is educated, he can overcome it by means of force. \# When people are stupid, they think force easy, but cleverness difficult; but if the world is clever, then it thinks knowledge easy, but force difficult. So, when ${ }_{* 6 \mathrm{~b}}$ Shen-nung taught ploughing and attained supreme sway, the leadership was by means of his knowledge. When T'ang and $\mathrm{Wu}$ made themselves strong and attacked the feudal lords, the subjugation was by means of force (705). Nowadays, the world is full of cleverness and people are dissolute, and at this juncture, when the times of T'ang and $\mathrm{Wu}$ are imitated, to practise the actions of Shen -nung ... (706) thus a country of a thousand chariots hereby falling into a state of disorder : this is paying particular attention to the wrong things.

It is people's nature, when measuring, to take the longest part, when weighing, to take the heaviest, when adjusting the scales, to seek profit. If an intelligent prince watches p.222 these three things diligently, order may be established in the country and the capacities of the people may be utilized. If the state makes few demands from the people, then the people will make many evasions from those demands. Direct the people at home to adhere to farming, and abroad to be concentrated in warfare. Therefore, a sage's way of administering a country is to prohibit much, in order to limit the people's capacity, and to rely on force in order to render trickeries powerless. These two methods being used in combination, people within the borders will be single-minded; being single-minded, they will farm; farming, they will be simple and being simple, they will dwell quietly and dislike going out. Therefore, a sage's way of ordering a country is that the people's capital should be stored in the soil, and that dangers should be run abroad by borrowing a temporary habitat.

If their capital lies in the soil, they will be simple, and if, by borrowing a temporary habitat abroad, dangers would be ${ }_{* 7}$ a run, they will be anxious. If at home the people are simple, and abroad they are anxious, then as a result they will exert themselves in farming and be alert in warfare. If the people are zealous in farming, then their capital will be considerable ; if they are alert in warfare, the neighbouring states will be in danger. If their capital is considerable, then they can not carry it on their backs (707) and go elsewhere ; if the neighbouring states are in danger, they will not go where there is no capital, for to go to a place of danger and to borrow a habitat outside, even a madman does not do such a thing. 
p.223 Therefore a sage, in ordering a country, looking to popular custom, fixes their laws with the result that there is order, and examining the state, gives his attention to what is fundamental (708), with the result that everything is fitting. When laws are fixed without looking to the customs of the times and without examining the fundamental things of the state, then the people will be in disorder, affairs will be troublesome, so that results will be few.

This is what I call error.

Now the idea of punishments is to restrain depravity, and the idea of rewards is to support the interdicts. Shame and disgrace, labour and hardship are what the people dislike (709); fame and glory, ease and joy are what the people pay attention to. So, if the penalties of the country are such that they do not cause dislike, and the titles and emoluments are not worth attention, it is an omen of the ruin of the country. If culprits often escape through the meshes, inferior people will be depraved and dissolute and will not think of the punishments as deterrents, and thus they will be applied to the people in a haphazard manner. That being so, and ${ }_{* 7 \mathrm{~b}}$ the way to fame and glory by means of gain not being one, then superior men will apply power to obtain a name and inferior people will not avoid what is prohibited. Therefore, the punishments will be numerous. If the superior man ${ }_{\text {p.224 }}$ does not set up his commands clearly, minor penalties will be applied. If punishments are numerous and minor penalties are applied, the country will have many criminals (710). Then the rich will not be able to keep their wealth, nor the poor to apply themselves to their occupations; the fields will lie fallow and the state will be poor.

If the fields lie fallow, the people will live by deceit; if the country is poor, the ruler will lack rewards. Therefore, when a sage administers a country, culprits have no government position and felons do not hold office. If culprits were to hold rank, then the superior man would resign from his position ; if felons (711) were to be clothed with brocades and fed with meat, then the inferior man would hope for such advantages. If superior men resigned from their positions, one would be ashamed of merit; if inferior men hoped for such advantages, one would boast of wickedness. So punishments and executions are the means whereby wickedness $* 8 \mathrm{a}$ is stopped, and office and rank are the means whereby merit is encouraged.

Nowadays, people spurn the ranks established by the state, and laugh at the punishments set up by it. This evil is caused by the law and method followed. Therefore, the superior ${ }_{\text {p.225 }}$ man, in handling his authority, unifies the government (712) in order to fix his methods; in establishing offices, he makes rank valuable, to correspond with them, and he makes his appointments, taking people's exertions into account and according to their merit, so that the balance between high and low is even. When this is the case, ministers will be able to exert their strength to the uttermost and the ruler to exercise autocratic sway. 


\section{Paragraph 7 \\ Opening and Debarring (713)}

During the time when heaven and earth were established, and the people were produced, people knew their mothers but not their fathers. Their way was to love their relatives and to be fond of what was their own. From loving their relatives came discrimination, and from fondness of what was their own, insecurity. As the people increased and were preoccupied with discrimination and insecurity, they fell into disorder. At that time, people were intent on excelling $*_{8 \mathrm{~b}}$ others and subjected each other by means of force ; the former led to quarrels, and the latter to disputes. If in disputes there were no justice, no one would be satisfied; ${ }_{\text {p.226 }}$ therefore men of talent established equity and justice and instituted unselfishness, so that people began to talk of moral virtue. At that time, the idea of loving one's relatives began to disappear, and that of honouring talent arose.

Now virtuous men are concerned with love and the way of talented men is to outvie one another. As people increased and were not restrained and had for long been in the way of outvying one another, there was again disorder. Therefore a sage, who received the administration, made divisions of land and property (714), of men and women. Divisions having been established, it was necessary to have restraining measures, so he instituted interdicts. These being instituted, it was necessary to have those who could enforce them. Thereupon he established officials. These having been established, it was necessary to have some one to unify them. So he set up a prince. Once a prince had been set up, the idea of honouring talent disappeared, and that of prizing honour arose. Thus in the highest antiquity, people loved their relatives and were fond of what was their own ; in middle antiquity, they honoured talent and talked of moral virtue; and in later days, they prized honour and respected office. Honouring talent means outvying one another with doctrines, but setting up a prince means relegating talented men to unemployment. *9a Loving one's relatives means making selfishness one's guiding principle, but the idea of equity and justice ${ }_{\text {p.227 }}$ is to prevent selfishness from holding the field. But these three methods did not aim at antagonistic purposes. The guiding principles of the people are base and they are not consistent in what they value. As the conditions in the world change, different principles are practised. Therefore it is said that there is a fixed standard in a king's principles. Indeed, a king's principles represent one viewpoint, and those of a minister another. The principles each follows are different, but are one in both representing a fixed standard. Therefore, it is said :

«When the people are stupid, by knowledge one may rise to supremacy; when the world is wise, by force one may rise to supremacy. 
That means that when people are stupid, there are plenty of strong men but not enough wise, and when the world is wise, there are plenty of clever men, but not enough strong. It is the nature of people, when they have no knowledge, to study; and when they have no strength, to submit. So when Shen-nung taught ploughing and attained supreme sway, the leadership was by means of his knowledge; when T'ang and $\mathrm{Wu}$ made themselves strong and attacked the feudal lords, the subjugation was by means of their force (715). That is, in the case of uneducated people, when they possess no knowledge, they are anxious to learn ; in the case of an educated society, not having force, it submits. Therefore, he who wishes to attain supreme sway by means of love, rejects punishments, and he who wishes p.228 to subjugate the feudal lords by means of force, relegates virtue to the background. A sage does not imitate antiquity, nor does he follow the present time (716). If he were to imitate antiquity, he would be behind the times; and if he follows the $* 9 \mathrm{~b}$ present time, he is obstructed by circumstances. The Chou dynasty did not imitate the Shang dynasty, nor did the Hsia dynasty imitate the period of Yü; the three dynasties encountered different circumstances, but all three succeeded in attaining supremacy. So to rise to supremacy, there is a definite way, but to hold it there are different principles. For example, $\mathrm{Wu}$ as a rebel seized the empire, and yet he prized obedience to the law; he disputed the empire, and yet exalted compliancy ; by force he seized it, but by righteousness he held it. Nowadays strong countries aim at annexation, while weak countries are concerned for defence by force, which means that compared with early times they are not equal to the times of Yü and Hsia, and compared with later times they do not practise the principles of T'ang and Wu. Because the principles of T'ang and $\mathrm{Wu}$ are obstructed, of the countries of ten thousand chariots there is not one that does not wage war, and of the countries of a thousand chariots there is not one that is not on the defence. These principles (of T'ang and Wu) have been obstructed a long time, and none of the rulers of the world is able to develop them. p.229 Therefore, there is not a fourth added to the three dynasties, and unless there be an intelligent ruler, there is none who succeeds in being obeyed. Now you want to develop the people by imitating the ancient rulers, but the people of old were simple through honesty, while the people of today are clever through artificiality. Wherefore, if you wish to imitate the ancients, you will have orderly government by promoting virtue, and if you wish to imitate modern times, you will have laws by emphasizing punishments, and this is commonly distrusted. What the world now calls righteousness is the $* 10$ a establishment of what people like and the abolishment of what they dislike (717), and what the world calls unrighteousness (718) is the establishment of what people dislike and the abolishment of that in which they take delight.

The names and practice of these two methods may be interchanged. \# It is necessary to examine this : if you establish what people delight in, then they will suffer from what they dislike; but if you establish what the people dislike, they will be happy in what they enjoy. How do I know that this is so ? Because, if people are in sorrow, they think, and in thinking they invent 
various devices. Whereas, if they enjoy themselves, they are dissolute, and dissoluteness breeds idleness. Therefore, if you govern by punishment the people p.230 will fear. Being fearful, they will not commit villainies; there being no villainies, people will be happy in what they enjoy. If, however, you teach the people by righteousness, then they will be lax, and if they are lax, there will be disorder; if there is disorder, the people will suffer from what they dislike. What I call profit is the basis of righteousness, but what the world calls righteousness is the way to violence. Indeed, in making the people correct, one always attains what they like by means of what they dislike, and one brings $* 10 \mathrm{~b}$ about what they dislike by means of what they like. In an orderly country, punishments are numerous and rewards rare (719). Therefore, in countries that attain supremacy, there is one reward to nine punishments, and in dismembered countries, nine rewards to every one punishment (720). Now, in proportion to the gravity or otherwise of the offence, there are light and heavy punishments, and in proportion to the greatness of the virtue, there are large or small rewards. These two differences are constantly applied in the world. p.231 If punishments are applied to accomplished crimes, then villainy will not be banished, and if rewards are bestowed for virtuous actions that have been achieved (721) by the people, then offences will not cease. Now, if punishments cannot banish villainy, nor rewards put an end to offences, there will doubtless be disorder. Therefore, in the case of one who attains supremacy, punishments are applied at the intent to sin, so that great depravity cannot be bred ; and rewards are bestowed on the denouncement of villainy, so that minor sins do not escape unnoticed. If, in governing a people, a condition can be brought about, wherein great depravity cannot be bred and minor offences do not escape unnoticed, the state will be orderly, and, being orderly, it is certain to be strong (222). If one country alone applies this method, there will be order only within its own borders ; if two countries ${ }_{\mathrm{p} .232}$ apply this method, the armies will have some rest; if the whole world applies this method, the highest state of virtue will be re-established. This is my way of reverting to virtue by death-penalties (723), and of making righteousness a corollary to violence.

Of old, people lived densely together and all dwelt in ${ }_{* 11 \text { a }}$ disorder, so they desired that there should be a ruler. However, why the empire was glad to have a ruler was because he would create order. Now, having rulers but no law, the evil is the same as if there were no rulers, and having laws that are not equal to the disorders is the same as if there were no law. The empire does not feel tranquil without a prince, but it takes pleasure in being stronger than the law (724), and thus the whole world is perturbed. Indeed, there is no greater benefit for the people in the empire than order, and there is no firmer order to be obtained than by establishing a prince ; for establishing a prince, there is no more embracing p.233 method than making law supreme; for making law supreme, there is no more urgent task than banishing villainy, and for banishing villainy, there is no deeper basis than severe punishments. Therefore those, who attain supremacy, restrain by rewards and encourage by 
punishments, seek offences and not virtue (25), and rely on punishments in order to abolish punishments. 


\section{CHAPTER 3}

\section{Paragraph 8 \\ $*_{1 \mathrm{a}}$ The Unification of Words}

p.234 When about to establish a state, it is necessary to examine standards and measures, to pay attention to law and order, to be vigilant in government duties, and to consolidate occupations with what is primary (726). When standards and measures are regulated in accordance with the times, the customs of the country may be changed and the people will follow the standard regulations; if rules and laws are clear, the officials will commit no depravity ; if the duties of the government are dealt with uniformly, the people will be available for use ; if occupations with what is primary are consolidated, people will take pleasure in agriculture and will enjoy warfare. Now a sage, in establishing laws, alters the customs and causes the people to be engaged in agriculture, night and day. It is necessary to understand this. \# Indeed, people abide by their avocations and obey the regulations even to death (727), when the honorific titles which the ruler has instituted, and the rewards and penalties which he has established, are clear, and when, instead of employing sophists and intriguers, men of merit are set up. The result will be that the people will take pleasure in farming and enjoy warfare, because they see that the ruler honours p. $235 * 1 \mathrm{~b}$ farmers and soldiers, looks down upon sophists and artisans, and despises itinerant scholars. Therefore, when the people concentrate on one occupation, their families will be rich and their persons will be distinguished in the country ; the ruler opens the way to public benefit and bars the gate of private intrigue, so that the people's strength is developed to the utmost. If toil in one's own interest does not gain distinction in the state, nor is admittance to the prince obtained through the gate of private intrigue (728), then under these circumstances, meritorious ministers will be encouraged, and in consequence the orders of the ruler will be performed, waste lands will be opened up, dissolute people will disappear, and villainies will not sprout. He, who, in administrating a country, is able to consolidate the people's strength and to make their occupation one, will be strong; he, who is able to make the people attend to what is primary, and to prevent what is secondary (729), is rich. A sage, in administrating a country, is able to consolidate its strength or to reduce it. When standards and measures are clear, then the people's strength is consolidated ; if it is consolidated, but not developed, it cannot take effect. If it does take effect, but there are no riches, it will give rise to disorder. Therefore, for one who administers a country, the way to consolidate its strength, is to make the country rich and its soldiers strong; the way to reduce the people's force is to attack the enemy and to encourage the people. If one only opens the way p.236 without barring 
the gate (730), the short will grow long (731); when it has grown, and one does not attack, there will be villainy ; if one debars without opening up, the people will be chaotic ; if they are chaotic, and one does not make use of them, their strength will become great; if their strength is great, and $*_{2 a}$ one does not attack, there will be villainy and the parasites (732). So, consolidating their strength is brought about by unifying their occupation ; reducing their force is brought about by attacking the enemy (733). In administrating a country, one should value the single-mindedness of the people ; if they are single-minded, they are simple, and being simple, they farm ; if they farm, they easily become diligent, and being diligent, they become rich. The rich should be despoiled of their riches (734) by means of titles (735), so that they do not become dissolute. Those who are dissolute should be divested of their dissoluteness by punishments, so that they may concern themselves with agriculture. Therefore, if one is able, only to consolidate force, and not to use it, disorder ensues ; and one, who is able, only to reduce force, but not to consolidate it, will perish. So an intelligent ruler, who knows how to combine these two principles, will be strong, but that ${ }_{\text {p.237 }}$ of one, who does not know how to combine these two, will be dismembered.

Indeed, if a people are not orderly, it is because their prince follows inferior ways; and if the laws are not clear, it means that the prince causes disorder to grow. Therefore, an intelligent prince is one, who does not follow an inferior way, nor causes disorder to grow, but he establishes himself, by maintaining his authority and creates order, by giving laws ; so that he gains possession of those, who are treacherous towards their ruler; thus for all officials respectively rewards or penalties are fixed, so that employment will have a fixed standard. Under these circumstances, then, the country's regulations will be clear and the people's force will be used to the utmost, the titles, granted by the ruler will be honoured and the . . . will be advanced.

The rulers of the present day all desire to govern the people, but their way of helping them is disorderly, not because they $* 2 \mathrm{~b}$ take pleasure in disorder, but because they rest on antiquity and do not watch for the needs of the times ; that is, the ruler models himself on antiquity, and as a result, is hampered by it ; subordinates follow the present and do not change with the times (736), and when the changes in the customs ${ }_{\text {p.238 }}$ of the world are not understood, and the conditions for governing the people are not examined, then the multiplication of rewards only leads to punishments, and the lightening of punishments only eliminates rewards (737). Indeed, the ruler institutes punishments, but the people do not obey; his rewards are exhausted, but crimes continue to increase ; for the people in their relation to the ruler, think first of punishments and only afterwards of rewards. \# The sage's way, therefore, of organizing a country is not to imitate antiquity, nor to follow the present, but to govern in accordance with the needs of the times, and to make laws which take into account customs. For laws, which are established without examining people's conditions, do not succeed, but a government which is enacted fittingly for the times, does not offend. Therefore, the government of the sage-kings examined 
attentively the people's occupations and concentrated their attention on unifying them and on nothing else. 


\section{Paragraph 9 \\ Establishing Laws}

I have heard that when the intelligent princes of antiquity established laws (738), the people were not wicked ; when they undertook an enterprise, the required ability was practised ${ }_{\text {p.239 }}$ spontaneously; when they distributed rewards, the army was strong. *3a These three principles were the root of government. Indeed, why people were not wicked, when laws were established, was because the laws were clear and people profited by them; why the required ability was practised spontaneously, when an enterprise was undertaken, was because merits were clearly defined; and because these were clearly defined, the people exerted their forces ; and this being so, the required ability was spontaneously practised ; why the army was strong when rewards were distributed refers to titles and emoluments. Titles and emoluments are the goal of a soldier's ambition (739). Therefore, the principle on which princes distributed titles and emoluments was clear; when this was clear, the country became daily stronger, but when it was obscure, the country became daily weaker. Therefore, the principle on which titles and emoluments are distributed is the key to the state's preservation or ruin. The reason why a country is weak or a prince is ruined is not that there are no titles or emoluments, but that the principles followed therein are wrong. The principle followed by the Three Kings and the five Lords Protector was no other than that of giving titles and emoluments, and the reason that people emulated each other in merit was because the principles which they followed were clear. Thus the way in which intelligent princes utilized their ministers was that their employment was made dependent on the work which ${ }_{\text {p.240 }}$ they had done, and rewards were bestowed on the merits which they had acquired (740). When the relation between merit and reward was clear, then the people emulated each other in merit. If, in administering a state, one succeeds in causing the people to exert their strength so that they emulate each other in merit, then the army will certainly be strong.

To be of the same rank as others and yet to stand to them *3b in such relations as subject or concubine points to poverty or wealth; to be of the same territory (741) as others and yet to be annexed by them points to strength or weakness; to have land, but the prince being in the one case strong and in the other weak, points to disorder or order. If there is a right method, even a territory of a square $l i$ is sufficient to give room to the body, and people may be attracted (to colonize), and if it but contains a market-place (742), riches may become many. Whoever has land cannot be called poor, and whoever has people cannot be called weak. If land is made truly productive, one need not be anxious about not being wealthy; if the people are truly employed, one need not fear force or p.241 violence; if virtue be clear and with the right 
teaching prevailing, one will succeed in utilizing for oneself what the people have. Therefore, the intelligent kings utilized what was not their own, and employed those who were not their own subjects (743). The point to which intelligent kings attached importance was that of rewarding with titles only men of real merit; if this condition was fulfilled, honour and outer marks of distinction were awarded to them. If there were no honour connected with them, then people would not be anxious for noble rank, and if there were no outer marks of distinction, then people would not be concerned about titles. If titles are easily obtained, then people do not appreciate the highest titles nor the various other titles; if emoluments and rewards are not obtained through a definite gate-way, people will not $*_{4 a}$ strive to the death for rank. For a prince there exists the fact that people have likes and dislikes; therefore, for it to be possible to govern the people, it is necessary that the prince should examine these likes and dislikes. Likes and dislikes are the basis of rewards and punishments. Now, the nature of man is to like titles and emoluments and to dislike punishments and penalties (744). A prince institutes these two in order to guide men's wills, and he establishes what they ${ }_{\text {p.242 }}$ desire (745). Now, if titles follow upon the people's exertion of strength, if rewards follow upon their ac quisition of merit, and if the prince succeeds in making people believe in this as firmly as they do in the shining of sun and moon (746), then his army will have no equal. Among the princes of men there are some who bestow titles, but whose army is weak ; there are some who grant emoluments, but whose state is poor; there are some who have fixed laws, but who yet suffer disorder. These three things are calamities for a country. For if a ruler of men places the making easy of audiences before the acquiring of merit, then although he bestows titles, his army will be weak ; if people, without risking their lives in dangers, can obtain profit and emoluments, then the granting of emoluments will only make the country poor. If the law has neither measures nor figures, then affairs will daily become more complicated, and although laws have been established, yet the result will be that the administration will be in disorder. Therefore, an intelligent prince, in directing his people, will so direct them that they will exert their ${ }_{\text {p.243 }}$ strength to the utmost, in order to strive for a particular merit ; and if, when they have acquired merit, riches and *4b honour follow upon it, there will be no bravery in private causes (747). Therefore, if this teaching spreads and becomes successful, then when that is the case, ministers will be loyal, princes intelligent, order manifest, and the army strong. Therefore, in general, an intelligent prince in his administration relies on force and not on virtue, and thus, without his being anxious or fatigued, merit will be established. When measures and figures have been instituted, law can be followed. Therefore, it is necessary that a ruler of men should pay attention to himself (748).

\# Indeed, Li Chu (749) saw an autumn's hair at a distance of more than a hundred paces, but he could not transfer (750) his sharp vision to others; Wu Huo (751) was able to lift a weight of a thousand chün (752), but could not 
transfer his great strength to others; and indeed sages cannot transfer to others the personality and nature that is inherent in them (753).

But that whereby success may be attained - that is the law. 


\section{Paragraph 10 \\ The Method of Warfare}

p.244 Generally in the method of warfare, the fundamental principle consists in making government measures supremely prevalent. If this is done, then the people concerned will have no disputes ; and having no disputes, they will have no thought of self-interest, but will have the interest of the ruler in mind. Therefore a real king, through his measures, will cause people to be fearful in fights between various cities (754), but brave in wars against external foes (755). If people $*_{5}$ a have been trained to attack dangers with energy, they will, as a result, think lightly of death. Should the enemy be routed as soon as the engagement has begun, and should he not stop in his rout, abstain from further pursuit. Therefore does the "Art of War" say (756) :

«In a big battle, in the event of victory, pursue the fugitives not further than $10 l i$; in a small battle, in the event of victory, pursue the fugitives not further than $5 \mathrm{li}$.

When hostilities begin, weigh the ${ }_{\text {p.245 }}$ strength (757) of the enemy; if your organization is not equal to his, do not engage him in battle; if your provisions are not equal to his, do not protract the war; if the enemy is numerically strong, do not invade his territory (758); if the enemy is in every way your inferior, attack him without hesitation. Therefore it is said :

« The great rule of an army is prudence.

By estimating the strength of the enemy and by examining one's own hosts, victory or defeat may be known beforehand (759).

The army of a real king does not boast of victory, nor does it harbour rancour for defeat. That it does not boast of victory is because it ascribes it to its clever tactics (760); that it does not harbour rancour for defeat is because it knows why it has failed. If the relative strength of the armies is well-matched (761), the side that has clever leadership will win, ${ }_{\text {p.246 }}$ and the side that has inferior leadership will lose. If the organization has its origin in the calculations made in the temple (762), then it will win, whether the leadership is clever or inferior. He who holds victorious tactics will be so strong that he will attain supremacy. If people are submissive and obey their ruler, then the country will become rich and the army victorious ; and if this state of affairs is maintained for long, he will surely attain supremacy.

${ }^{*} 5$ b But it is a mistake for an army to penetrate deeply into the enemy's country, in difficult and unsurmountable terrain and cut off in a cul-de-sac ; the men will become exhausted, hungry and thirsty as well, and will, moreover, fall victims to disease. This is the way to defeat (763). Therefore he 
who ${ }_{\text {p.247 }}$ intends to direct the people ... and he who mounts a good horse cannot but be on his guard. 


\section{Paragraph 11 \\ The Establishment of Fundamentals}

Generally, in the utilizing of soldiers, there are three stages to victory: prior to the outbreak of hostilities, laws should be fixed (764); laws being fixed, they should become the custom ; when they have become customary, supplies should be provided. These three things should be done within the country before the soldiers can be sent abroad. For performing these three things, there are two conditions ; the first is to support the law, so that it can be applied; the second is to obtain the right men in appointments, so that the law can be established. For reliance on masses is said to be the assembling of a mob; reliance on outward appearances is said to be smartness ; reliance on fame and sight is said to be deceitfulness. If one relies on any one of these three, one's soldiers may be captured. Therefore is it said :

«The strong are unbending; they fight for what they desire. By fighting, their strength develops to the full, and ${ }_{* 6 a}$ thus they are prepared. In this way, they have no rival in the four seas, and by order prevailing, products are accumulated; $\mathrm{p} .248$ by the accumulation of products, it is possible for the rewards to be big.

If rewards are uniform, rank will be honoured; if rank is honoured, rewards will bring profit. Therefore is it said :

« The army, being based on a state of order, there is a marvellous result; custom, being based on law, ten thousand changes of circumstances are brought about ; a condition of supremacy, being based upon the mind, it is outwardly manifested in a condition of preparedness. If these three points of view are all taken into consideration, the result will be that the strong may be firmly established.

Thus orderly government is the necessary result of strength, and strength again of orderly government ; orderly government of riches, and riches again of orderly government; riches of strength, and strength again of riches. Therefore is it said :

«The way to orderly government and strength is to discuss fundamentals. 


\section{Paragraph 12 Military Defence}

A state that has to fight on four fronts values defence, and a state that rests against the sea values attack. For, if a state that fights on four fronts is fond of raising soldiers, it will be in a dangerous position, as it has to resist four p.249 neighbours. As soon as a country with four neighbours begins hostilities, four countries mobilize armies; therefore is it said that the country is in a dangerous position (765). If a state that has to fight on four fronts is unable to raise (766), from a city of ten thousand houses, an army of more than ten thousand ${ }_{* 6 \mathrm{~b}}$ men, then the state will be in a dangerous position. Therefore is it said :

«A state that has to fight on four fronts should concern itself with defensive warfare.

In defending walled cities, the best way is, with the strength of the worn-out men, to fight the fresh strength of the invaders. It is assaults upon walled cities that wear out the strength of men (767). So long as the walled cities have not all been razed, the invaders have no means of penetrating the country. This is meant by the saying that the strength of worn-out men should fight the fresh strength of the invading force. But when the walled cities have all been razed and the foreign army thus finds the means of penetrating, then certainly it will be exhausted, and the people within the country will be rested. Fighting with rested strength against those of exhausted strength is said to be : fighting with the strength of fresh men against the worn-out strength of the invading forces (768). All these are called the misfortunes ${ }_{\text {p.250 }}$ attendant upon the besieging of walled cities. It is regarded as a misfortune that always, in capturing cities, the strength of the army is worn out. In these three things misfortune is due, not to insufficient effort, but to mistaken generalship (769).

The way to hold a city is to have abundant strength. Therefore is it said :

«When the invading force musters its levies, mobilize as many as three armies, and divide them according to the number of the chariots of the invading force.

Of these three armies, one should be formed of able-bodied men, one of able-bodied women, and one of the old and feeble men and women. These are called the three armies. Cause the army of able-bodied men, with abundant provisions and sharp weapons, to marshal themselves and to await the enemy; cause the able-bodied women, with abundant ${ }_{* 7 \text { a }}$ provisions and ramparts at their backs, to marshal themselves and to await orders, so as to make, at the approach of the invaders, earthworks as an obstruction, and traps, chevaux-de-frise and pitfalls, to pull down the supporting beams and to tear down the houses, to transport what is ${ }_{\text {p.251 }}$ transportable (770), and to burn what 
is untransportable, so that the invaders are not able to make use thereof in their attack. Cause the army of the old and feeble to guard the oxen, horses, sheep and swine, and to collect all that is consumable of plants and water, to feed them therewith, so as to obtain food for the able-bodied men and women. But see to it carefully that the three armies do not intermingle. If the ablebodied men mingle with the army of the able-bodied women, they will attach great value to the safety of the women, and wicked people will have opportunities for intrigue, with the result that the state will perish. Taking pleasure in the women's company, the men will be afraid of disturbing reports and so not even the brave will fight. If the able-bodied men and women intermingle with the army of the old and feeble, then the old will arouse the compassion of the able-bodied, and the feeble the pity of the strong. Compassion and pity in the heart cause brave people to be more anxious and fearful people not to fight. ${ }_{\text {p.252 }}$ Therefore is it said :

«See to it carefully that the three armies do not intermingle.

This is the way to have abundant strength. 


\section{Paragraph 13 (771) Making Orders Strict (772)}

*7b If orders are made strict, orderly government is not delayed, and if laws are equable, officials are not wicked. Once the law is fixed, one should not damage it with virtuous words ; if men of merit are appointed to office, people will have little to say ; but if men of virtue are appointed to office, people will have much to say. The practice of good government begins with making judgments. Where five hamlets are the unit for judgments, supremacy is attained; where ten hamlets are the unit for judgments, there is merely strength (773). He who procrastinates in creating order will be dismembered. Govern by punishments and wage war by rewards ; \# seek ${ }_{\text {p. } 253}$ transgressors and do not seek the virtuous (774). Therefore, if the law is fixed and not altered, then ... If in the country there are no wicked people, there is no wicked trade in the capital. If affairs are many and secondary things (775) are numerous, if agriculture is relaxed and criminals gain the upper hand, then the country will certainly be dismembered.

If the people have a surplus of grain, cause them to obtain office and rank by means of their cereals (776); if through their own efforts they can count upon obtaining office and rank, farmers will not be lazy.

If a tube of no more than four inches has no bottom, it can certainly not be filled ; to confer office, to give rank and to grant salaries, without regard to merit, is like having no bottom.

If a state, when poor, applies itself to war, the poison will originate on the enemy's side, and it will not have the six parasites, but will certainly be strong. $* 8$ a If a state, when rich, does not apply itself to war, the poison is transferred to ${ }_{\text {p.254 }}$ its own interior, and it will have the six kinds of parasites and will certainly be weak (777). \# If the state confers office and gives rank according to merit, it may be said to be planning with complete wisdom, and fighting with complete courage (778). Such a country will certainly have no equal. If a state confers office and gives rank according to merit, then government measures will be simple and words will be few. This may be said to be abolishing laws by means of the law (779) and abolishing words by means of words. But if a state confers office and gives rank (780) according to the six parasites, then government measures will be complicated and words will arise. This may be said to be bringing about laws ${ }_{\text {p.255 }}$ by means of the law (781) and causing volubility by means of words. Then the prince will devote himself to talking; officials will be distracted with ruling the wicked ; wicked officials will gain their own way, and those who have merit will retire more daily. This may be said to be failure (782). When one has to observe ten rules, there is confusion: when one has only one to observe, there is order (783). When the law is fixed, then those who are fond of practising the six parasites perish. If 
people occupy themselves entirely with agriculture, the state is rich ; if the six parasites are not practised, then soldiers and people will, without exception, vie with one another for encouragement and will be glad to be employed by their ruler; the people within the borders will vie with one another to regard it as glorious, and none will regard it as disgraceful. Following upon this comes the condition where people will do it because they are encouraged by means of rewards and restrained by means of punishment. $* 8 \mathrm{~b}$ But the worst case is when people hate it, are anxious about it, and are ashamed of it; then they adorn their outer appearances and are engaged in talking; they are ashamed of taking a position and exalt culture. In this way they shun agriculture and war, and ${ }_{\text {p.256 }}$ outside interests being thus furnished, it will be a perilous position for the country. To have people dying of hunger and cold, and to have unwillingness to fight for the sake of profit and emolument, are usual occurrences in a perishing state. \# The six parasites are : rites and music, odes and history, moral culture and virtue, filial piety and brotherly love, sincerity and faith, chastity and integrity, benevolence and righteousness, criticism of the army and being ashamed of fighting. If there are these twelve things, the ruler is unable to make people farm and fight, and then the state will be so poor that it will be dismembered (784). If these twelve things come together, then it may be said that the prince's administration is not stronger than his ministers and that the administration of his officials is not stronger than his people (785). This is said to be a condition where the six parasites are stronger than the government. When these twelve gain an attachment (786), then dismemberment ensues. Therefore to make a country prosperous, these twelve things should not be practised; then the (787) state will have much strength, and no one in the empire will be able to invade it. When its soldiers march out, they will capture their objective, and having captured it, will be able to hold it. When it keeps ${ }_{\text {p.257 }}$ its soldiers in reserve and does not attack, it will certainly become rich (788). The court officials do not reject any merits, however few they may be, nor do they detract from any merits, however many they may be (789). Office and rank are obtained according to the acquired merit, and even though there may be sophistical talk, $*_{9 \mathrm{a}}$ it will be impossible thereby to obtain undue precedence. This is said to be government by statistics. In attacking with force, ten points are gained for every one point undertaken, but in attacking with words, a hundred are lost for every one marched out. If a state loves force, it is said to attack with what is difficult; if a state loves words, it is said to attack with what is easy (790). If penalties are heavy and rewards few, then the ruler loves his people and they will die for him ; if rewards are heavy and penalties light, then the ruler does not love his people nor will they die for him (791).

If the profit disappears through one outlet only, the state ${ }_{\text {p. } 258}$ will have no equal ; if it disappear through two outlets, the state will have only half the profit; but if the profit disappears through ten outlets, the state will not be preserved (792). If heavy penalties are clear, there will be great control, but if they are not clear, there will be the six parasites. If the six kinds of parasites 
come together, then the people are not fit for employment. Therefore, in a prosperous country, when punishments are applied, the people will be closely associated with the ruler, and when rewards are applied they will reap profit (793).

\# In applying punishments, light offences should be punished heavily (794) ; if light offences do not appear, heavy offences ${ }_{\text {p. } 259}$ will not come. This is said to be abolishing penalties by means of penalties, and if penalties are abolished, affairs will succeed (795). If crimes are serious and penalties light, penalties $* 9 \mathrm{~b}$ will appear and trouble will arise. This is said to be bringing about penalties by means of penalties, and such a state will surely be dismembered (796).

A sage-prince understands what is essential in affairs, and therefore in his administration of the people there is that which is most essential (797). For the fact that uniformity in the manipulating of rewards and punishments supports moral virtue, is connected with human psychology. A sage-prince, by his ruling of men, is certain to win their hearts; consequently he is able to use force. Force produces strength, strength produces prestige, prestige produces virtue, and so virtue has its origin in force (798), which a sage-prince alone possesses, and therefore he is able to transmit benevolence and righteousness to the empire. 


\section{Paragraph 14 The Cultivation of the Right Standard (799)}

p.260 Orderly government is brought about in a state by three things. The first is law, the second good faith (000), and the third right standards. Law is exercised in common by the prince and his ministers. Good faith is established in common by the prince and his ministers. The right standard is fixed by the prince alone (801). If a ruler of men fails to observe it, there is danger ; if prince and ministers neglect the law and act according to their own self-interest, disorder is the inevitable result. Therefore if law is established, rights and duties are made clear (802), and self-interest does not harm the law, then there is orderly government. If the fixing of the right standard is decided by the prince alone, there is prestige. If the people have faith in his rewards, then their activities will achieve results, $* 10$ a and if they have faith in his penalties, p.261 then wickedness will have no starting point (803). Only an intelligent ruler loves right standards and values good faith, and will not, for the sake of self-interest, harm the law. For if he speaks many liberal words but cuts down his rewards, then his subjects will not be of service; and if he issues one severe order after another, but does not apply the penalties, people will despise the death-penalty.

In general, rewards are a civil measure and penalties a military. Civil and military measures (804) are the summary of the law. Therefore an intelligent ruler places reliance on the law (05); (an intelligent ruler), if things are not kept hidden from him, is called intelligent, and if he is not deceived, is called perspicacious. Therefore he benefits by giving liberal rewards, and by making penalties severe, he ensures that he is feared. He does not neglect those that are distant, nor does he run counter to those that are near. Thus ministers will not hide things from their ruler, nor will inferiors deceive their superiors. Those who are engaged in governing, in the world, chiefly dismiss the law and place reliance on ${ }_{\text {p.262 }}$ private appraisal, and this is what brings disorder in a state. \# The early kings hung up scales with standard weights, and fixed the length of feet and inches, and to the present day these are followed as models $(\underline{806})$ because their divisions were clear. Now dismissing standard scales and yet deciding weight, or abolishing feet and inches and yet forming an opinion about length - even an intelligent merchant would not apply this system, because it would lack definiteness. \# $*_{10 \mathrm{~b}}$ Now, if the back is turned on models and measures, and reliance is placed on private appraisal, in all those cases there would be a lack of definiteness. Only a Yao would be able to judge knowledge and ability, worth or unworth without a model. But the world does not consist exclusively of Yaos! Therefore, the ancient kings understood that no reliance should be placed on individual opinions or biassed approval, so they set up models and made the distinctions clear. Those who fulfilled the 
standard were rewarded, those who harmed the public interest were punished (807). The standards for rewards and punishments were not wrong in their appraisals, and therefore people did not dispute them. But if the bestowal of office and the granting of rank are not carried out according to the labour borne, then loyal ministers have no advancement ; and if in awarding rewards and giving emoluments ${ }_{\text {p.263 }}$ the respective merits are not weighed (808), then fighting soldiers will not enter his service.

Generally, the principle on which ministers serve their prince are dependent, in most cases, on what the ruler likes. If the ruler likes law, then the ministers will make law their principle in serving; if the prince likes words, then the ministers will make words their principle in serving. If the prince likes law, then upright scholars will come to the front, but if he likes words, then ministers full of praise for some and blame for others will be at his side (809). If public and private interests are clearly distinguished, then even small-minded men do not hate men of worth, nor do worthless men envy those of merit. For when Yao and Shun established their rule over the empire, they did not keep the benefits of the empire for themselves, $* 11$ a but it was for the sake of the empire that they established their rule. In making the imperial succession dependent on worth and ability, they did not intend to alienate fathers and sons from one another, and to conciliate distant people (810), but they did it because they had a true insight into the ways of order and disorder.

So, too, the Three ${ }_{\text {p.264 }}$ Kings conciliated people by righteousness, and the five Lords Protector rectified the feudal lords by law; that is, in all these cases, none took for himself the benefits of the empire. They ruled for the sake of the empire, and thus, when those who held positions had corresponding merit, the empire enjoyed their administration and no one could harm it.

But, nowadays, princes and ministers of a disorderly world each, on a small scale, appropriates the profits of his own state, and each exercises the burden of his own office, for his private benefit. This is why the states are in a perilous position. For the relation between public and private interests is what determines existence or ruin.

However, if models and measures (811) are abolished and private appraisal is favoured, then bad ministers will let their standards be influenced by money (812), in order to obtain emoluments, and officials of the various ranks will, in a stealthy and hidden manner, make extortions from the people. The saying runs :

«Many woodworms and the wood snaps, a ${ }_{\mathrm{p} .265}$ large fissure and the wall collapses (1ㅗ).

So if ministers of state vie with one another in selfishness and do not heed the people, then inferiors are estranged from superiors. When this happens, there is a fissure in the state. $*_{11}$ If the officials of the various ranks make extortions from the people, stealthily and in a hidden manner, they are for the people like woodworms. Therefore is it exceptional in the world that where there are fissures and woodworms, ruin does not follow. That is why intelligent kings 
placed reliance on the law and removed self-interest, so that the state should have no fissures and no woodworms (814). 


\section{CHAPTER 4}

\section{${ }_{* 1 a}$ Paragraph 15 \\ The Encouragement of Immigration}

p.266 \# In a territory of a hundred square $l i$, a tenth should be occupied by mountains and hills, a tenth by glades and morasses, a tenth by valleys, dales, and running water, a tenth by cities, towns, and highways, a tenth by barren fields, and four-tenths by fertile fields (1ㅗ). In this way 50,000 workmen can be fed ; those mountains and hills, glades and morasses, valleys and dales, are able to provide the required material, and the cities, towns and highways are sufficient to accommodate the people concerned. This was the proportion according to which the early kings regulated the land and divided the people. Now, the territory of Ch'in comprises five times a thousand square $l i(816)$, but the soil fit for growing corn cannot occupy more than two-fifths. The area of the fields does not come up to a million $m u$, and the produce and treasures of its glades and morasses, of its valleys and dales, and of its famous mountains and big rivers, are also incompletely utilized. This means that the population is illproportioned to the territory. The neighbours of Ch'in are the three Chin states (817), and of these Han and Wei are fond of employing soldiers. Their territory is narrow, but their ${ }_{\text {p.267 }}$ population is numerous ; $* 1 \mathrm{~b}$ their dwellings are built higgledy-piggledy, and they live close together; their grain production is small, and merchants charge interest (818).

The people on the one hand do not have their names registered (819) and on the other hand have no fields or houses, so that for subsistence they rely on evil occupations and pursuits of minor importance (820), with the result that those who are exempt from taxation because they live in steep and inaccessible places, in morasses and by streams, are more than a half of the population. Therefore, it would appear that a condition where the territory is not sufficient to support the population is still worse than that where, as in the case of Chin, the population is insufficient to fill the territory.

In reflecting upon the nature of the people, what they desire are fields and houses. Now, whereas it is probable that these are what Chin does not have, it is beyond doubt that Ch'in has them in surplus. If, this being so, people do not, nevertheless, come west, it is because the soldiers of Ch"in are in sad plight and the people suffer hardships. I venture to think that the intelligence of Your Majesty's (821) p.268 officials takes a mistaken view : that is, the reason why we remain weak and do not succeed in enticing the people of the three Chin states, is that we are sparing in granting titles and regard the exemption from taxes as a serious matter. They argue as follows : 
«The three Chin states are weak because their people are concerned with pleasure and because exemptions and rank are treated lightly. Ch'in, on the other hand, is strong because its people are concerned with hard work, and exemptions and the conferment of rank are treated seriously; should we now confer many titles and grant exemptions from taxation for long periods, $*_{2 \mathrm{a}}$ then we should be letting go of the principle by which Chin has become strong and should be doing exactly that which has made the Chin states weak.

This is the argument that causes Your Majesty's officials to regard the conferring of titles as a serious matter, and to be sparing in the granting of exemptions from taxation.

I venture, however, to think that this is wrong. The object in causing the people hardship and in strengthening the army is to attack the enemy and to realize one's desires. The "Art of War" (822) says :

'If the enemy is weak, the arm y is strong.

This expression means that one does not fail in attack, but the enemy fails in defence. Now for four generations the Chin states have gained no victory over Ch'in. Since the time of King Hsiang of Wei (223), the times that the three ${ }_{\text {p.269 }}$ Chin states have been defeated by Chin, in small or big battles, in open battle or in storming defended cities, have been innumerable. The reason that in spite of this they do not submit to Ch'in is that Ch'in has been able to conque $r$ their territory, but unable to captivate their people.

Now, if Your Majesty will issue a favourable proclamation to the effect that those soldiers of the various feudal lords who will come and submit, will be granted exemption for three generations, without hearing anything of military affairs, and that those who live within the four boundaries of Chin, in the mountains and on the slopes, on hills and in marshes, will not be called upon for ten years for military service, and if this is made clear in the law, it will be possible to create a million workers. I have said before :

$\ll *_{2 b}$ In reflecting upon the nature of the people, what they desire are fields and houses. Now, whereas it is probable that Chin does not have these, it is certain that Ch'in has them in surplus. If in spite of this the people do not migrate westward, it is because the soldiers of Ch'in are in sore plight, and the people suffer hardships.

Now, if they are benefited with land and houses, and exemption from taxes for three generations is granted them, that is, if a point is made of giving them what they desire and of not causing them to perform what they dislike, then all the people from east of the mountains will migrate westward.

p.270 Moreover, to state the case frankly: if You do not act thus, You may fill the empty and waste lands and produce natural wealth, so that a million people are engaged in the fundamental occupation (824), and the benefits will 
be manifold, but how will You prevent the soldiers from failing in their attacks? Indeed, the trouble with Ch'in is, on the one hand, that if it raises soldiers and wages war, the country is poor, and on the other hand, if it remains quiet and farms, the enemy obtains respite. Your Majesty cannot combine success in these two fields. So, although for three generations (825) it has waged successful wars, yet it has not subjected the empire. Now, if the old population of Chin are engaged in warfare, and if the newcomers are caused to occupy themselves with agriculture, *3a then even though the army may stay a hundred days outside the frontier, within the borders not a moment will be lost for agriculture. Thus You may be successful both in enriching and in becoming strong.

When I speak of soldiers, I do not mean that all should be raised and mobilized to the last man, but according to the number of armies, soldiers, chariots and cavalry that can be furnished within the territory, cause the old population of Chin to serve as soldie rs and the new people to provide ${ }_{\text {p.271 }}$ fodder and food. Should there be a state in the empire that does not submit, then Your Majesty should, herewith, in spring prevent their farming, in summer live on their produce, in autumn lay hold of their harvest, and in winter pickle their vegetables : by the methods of the "Great Warfare" shake their fundamental means of existence, and by those of the 'Extensive Culture" (826) pacify their descendants (827). If Your Majesty follows this policy, then within ten years the various feudal lords will have no people from other countries (288) and wherefore, then, should Your Majesty be sparing in the conferment of titles or regard exemption from taxes as a serious matter ?

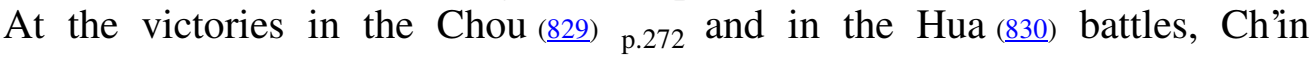
extended its territory eastwards by cutting off heads, but it is clear that there was no advantage in this eastward extension; and yet officials regard these events as great accomplishments, because loss was inflicted on the enemy. Now, if the people of the three Chin states are induced to immigrate by means of grasslands and cottages, and if they are made to occupy themselves with primary things, then this way of inflicting damage on the enemy is just as real as a victory in war, and Ch'in will have the advantage of obtaining agricultural products. Conversely, by this plan, two birds will be hit with one stone. $* 3 \mathrm{~b}$ Further, in the victories in the Chou and Hua battles, or in that at Ch'ang -ping (831), how many people did Ch'in lose, and how many soldiers, both of the people and of the foreign inhabitants, were unable to occupy themselves with primary affairs? I venture to think that they were innumerable. Suppose amongst Your Majesty's ministers there should be one able, with a half of these losses, to weaken Chin and to ${ }_{\text {p.273 }}$ strengthen Ch'in as much as by the victories in these three battles, then would Your Majesty, no doubt, grant him big rewards. Now, by the method which I propose, the people would not have a single day's scutage nor would the officials have the expense of great sums of money, while Chin would be weakened and Ch'in strengthened more than by three battles; but if Your Majesty still does not approve, then Your servant is too stupid to understand it. 
Amongst the citizens of Ch'i was one Tung-kuo Ch'ang, who had very many desires and wished to have ten thousand pieces of gold. When his retainer begged for a monetary subsidy (in case he would obtain that money), he would not give it, saying :

- I want to use it to obtain a fief.

His retainer became angry, and left him and went to Sung, saying :

- This is being stingy about what he has not ; therefore he is now in a worse position than when he first had me with him (832).

Now Chin has the people, and Chin is sparing in the granting of exemptions from taxes; this is being stingy about what one has not, with the result that one loses what one might have. Is this not just like Tung-kuo Ch'ang's *4a being stingy about what he did not have, and so losing his retainer ? (833)

Moreover, in antiquity, there were Yao and Shun, who in their lifetime were praised; in the middle ages there were T'ang and $\mathrm{Wu}$, during whose reigns people submitted. These ${ }_{\text {p. } 274}$ are the three $(\underline{834})$ Kings, who are praised by ten thousand generations and are regarded as sage-kings. Yet their methods cannot be applied in later times: Should You now make exemptions from taxation for three generations, You would be able completely to subject the three Chin states. This is not, like the virtuous kings, merely establishing the present times .... but effecting that later generations shall be at the service of the king (835)! This, however, does not mean that I do not welcome a sage, but it is difficult to await a sage.

Paragraph 16

Compendium of Penalties

(Lost) 


\section{Paragraph 17 \\ Rewards and Punishments}

The way in which a sage administers a state is by unifying rewards, unifying punishments, and unifying education. The effect of unifying rewards is that the army will have no equal ; the effect of unifying punishments is that orders will be carried out; the effect of unifying education is that inferiors will obey superiors. Now if one understands rewards, ${ }_{\text {. }} 275$ there should be no expense ; if one understands punishments, there should be no death penalty ; if one understands education, $* 4 \mathrm{~b}$ there should be no changes (836), and so people would know the business of the people and there would be no divergent customs. The climax in the understanding of rewards is to bring about a condition of having no rewards; the climax in the understanding of punishments is to bring about a condition of having no punishments; the climax in the understanding of education is to bring about a condition of having no education.

What I mean by the unifying of rewards is that profits and emoluments, office and rank, should be determined exclusively by military merit, and that there should not be different reasons for distributing them. For thus the intelligent and the stupid, the noble and the humble, the brave and the timorous, the virtuous and the worthless, will all apply to the full whatever knowledge they may have in their breasts, exert to the uttermost whatever strength they may have in their limbs, and will be at the service of their ruler even to death; and the outstanding heroes, the virtuous and the good, of the whole empire will follow him, like flowing water, with the result that the army will have no equal, and commands will be carried out throughout the whole empire. A country of ten thousand chariots will not dare to assemble its soldiers in the plains of the Middle Kingdom; nor will a country of a thousand chariots dare to defend a walled city. Should a country of ten thousand chariots assemble its soldiers in the plains of the Middle Kingdom, one would in battle, rout its army ; and should a ${ }_{\text {p.276 }}$ country of a thousand chariots defend a walled city, one would in the assault, capture that town. If, in battles, one always routs the other's army and, in assaults, one always captures the other's towns, with the result that finally one has all the cities, and all their riches accrue, then what expense or loss can one suffer, even though there are rich congratulatory rewards ?

*5a In days of old, T'ang was inves ted with Tsan-mao (837), Wen-wang was invested with Ch'i-chou (838), a district of a hundred square $l i$, T'ang fought a battle with Chieh in the fields of Ming-t'iao (839), Wu-wang fought a battle with Chou in the fields of $m u$ (840), and utterly defeated the "nine armies" (841), and finally split up the land and gave fiefs to the feudal lords. The officers and soldiers, who retired from the ranks, all received land, with the peasants 
belonging to it, in hamlets ${ }_{\text {p.277 }}$ of 25 families $(\underline{842)}$; the chariots were given a rest, and were no longer mounted; the horses were set at liberty on the southern slopes of Mount Hua ; the oxen were set at liberty in the meadows, and they were allowed to grow old without being reassembled (for war) (843). This was the way of T'ang and Wu of giving rewards. Therefore is it said :

«If all the people in the empire had had to be rewarded with the produce of Tsan-mao and Ch'i-chou, no one would have received a pint, and if all the people of the empire had had to be rewarded with its money, no one would have received a cash.

Therefore is it said :

«If a prince of a territory of a hundred $l i$ invests his ministers with fiefs, he greatly increases his original territory.

How is it that the rewards received, beginning with those to officers and soldiers retired from the ranks, which consisted of land, with the peasants belonging to it, p.278 in hamlets of 25 families, were even more liberal than those to horses and oxen? Because they (those kings) knew well how to reward the people of the empire according to the possessions of the empire. Therefore do I say :

«If one understands rewards there is no expense.

Since T'ang and Wu destroyed Chieh (44) and Chou (45), no harm was done within the four seas, and the empire enjoyed great stability ; $*_{5 b}$ the five storehouses were constructed, the five weapons were stored away, military affairs were set aside, culture and education were practised, shields and spears were carried reversed, writing tablets were stuck in the girdle (846), and music was performed in order to manifest one's virtue — such a condition of affairs prevailed in those times. Rewards and emoluments were not bestowed and yet the people were orderly. Therefore I say :

« The climax in the understanding of rewards is to bring about a condition where there are no longer rewards.

What I mean by the unification of punishments $(\underline{847)}$ is that punishments should know no degree or grade, but that from ministers of state and generals down to great officers and ordinary folk, whosoever does not obey the king's commands, violates the interdicts of the state, or rebels against the statutes fixed by the ruler, should be guilty of death and p.279 should not be pardoned (848). Merit acquired in the past should not cause a decrease in the punishment for demerit later, nor should good behaviour in the past cause any derogation of the law for wrong done later. If loyal ministers and filial sons do wrong, they should be judged according to the full measure of their guilt, and if amongst the officials who have to maintain the law and to uphold an office, there are those who do not carry out the king's law, they are guilty of death and should not be pardoned, but their punishment should be extended to their family for three generations (849). Colleagues who, knowing their offence, 
inform their superiors will themselves escape punishment. In neither high nor low offices should there be an automatic hereditary succession to the office, rank, lands or emoluments of officials. Therefore do I say that if there are severe penalties that extend to the whole family, people will not dare to try (how far they can go), and as they dare not try, no punishments will be necessary (850). $* 6$ a The former kings, in making their interdicts, did not put to death, or cut off people's feet, or brand people's faces, because they sought to harm those people, but with the object of prohibiting wickedness and stopping crime; for there is no better means of prohibiting wickedness and p.280 stopping crime than by making punishments heavy. If punishments are heavy and rigorously applied, then people will not dare to try (how far they can go), with the result that, in the state, there will be no people punished. Because there are no people punished in the state, I say that if one understands punishments, there is no capital punishment.

Duke Wen of Chin (851) wished to make clear the system of punishments, in order to gain the affection of the people. Thereupon, he assembled together all the feudal lords and great officers in the Shih-ch'ien Palace, but Tien Hsieh arrived too late and asked for punishment (852). The prince said :

- Employ stabbing ( $\underline{853})$,

and the lictors thereupon cut through Tien Hsieh's spine and made him die an expiatory death. The scholars of the state of Chin, having investigated the matter, were all afraid, and said :

- Considering that Tien Hsieh was a favourite and still he has been sawn through, as an expiatory death, how will it fare with us ?

He raised an army and attacked Ts'ao and $\mathrm{Wu}-\mathrm{lu}$. He also overturned the lowlands of Cheng and veered towards the east the fields p.281 of Wei; he conquered the people of Ching at Ch'eng-p'u (854)(855). *6b The soldiers of his three armies were so disciplined that stopping them was as if their feet were cut off (856) and in marching they were like flowing water, and none of the soldiers of the three armies dared to transgress his prohibitions. So by basing himself on this one affair of Tien Hsieh, where a light offence was severely punished, Duke Wen caused the state of Chin to enjoy order.

Formerly Tan, Duke of Chou, killed his younger brother Kuan and banished his younger brother Huo, saying:

- They have transgressed against the interdicts.

The multitudes in the empire all said :

- If, when (the ruler's) own brothers commit a fault, he does not deviate from the ${ }_{\text {p.282 }}$ law, how will it fare then with those who are distant and far off? 
Therefore, the empire knew that sword and saw were applied to members of the court of Chou, and consequently all within the seas enjoyed order (857). Therefore do I say :

«The climax in the understanding of punishments is to bring about a condition where there are no longer punishments.

What I mean by the unification of education is that all those partisans of wide scholarship, sophistry, cleverness, good faith, integrity, rites and music (858), and moral culture, whether their reputations are unsullied or foul, should for these reasons not become rich or honoured, should not discuss punishments, and should not compose their private views independently and memorialize their superiors. The strong should be broken and the sharp be blunted.

Although one may be called a sage or wise or clever or eloquent or liberal or simple, yet one must not if one lacks merit, ${ }_{* 7 \mathrm{a}}$ monopolize (859) the ruler's favours, but the gate to riches and honour should lie in war and in nothing else. Those who are capable in war tread through the gate to riches and honour, but for the violent and self-willed there are inflexible p.283 punishments and no pardon. Thus fathers and seniors, elder and younger brothers, acquaintances, relatives by marriage, husband and wife, one and all say that that, to which they devote special application, is war and that alone. Therefore indeed, the strong devote themselves to warfare, the old and feeble devote themselves to defence; for those who die there is no regret, and the living are bent on exerting themselves. This is what I mean by unifying education. The desire of people for riches and honour does not generally cease before their coffins are closed, and when the gate to riches and honour has its approach in soldiering, then when people hear of war, they congratulate each other, and whether at work or at rest, at times of drinking or eating, they will sing songs of war. This is what I mean by saying, that the climax in the understanding of education is to bring about a condition where there is no longer education.

This is what I mean by the three teachings. A sage cannot have a universal knowledge of the needs of ten thousand beings, ${ }_{* 7 \mathrm{~b}}$ therefore in his administration of a state, he selects what is important for dealing with the ten thousand beings (860). So there is little instruction, but much successful effort. The way in which a sage governs a state is easy to know, but difficult to practice. Therefore, that sages need not be increased, common-place rulers need not be abolished, that the killing of men is no violence and the rewarding of men no benevolence, follow from the fact that the law is clear. The sage confers ${ }_{\text {p. } 284}$ office and grants rank according to merit, therefore men of talent are not anxious. The sage is not indulgent with transgressions and does not pardon crimes, and so villainy does not spring up. The sage, in administering a state, investigates the possibilities of uniformity, and that alone. 


\section{Paragraph 18 Policies}

Of old, in the times of the Great and Illustrious Ruler (861), people found their livelihood by cutting trees and slaying animals; the population was sparse, and trees and animals numerous. In the times of Huang-ti, neither young animals nor eggs were taken (862); the officials had no provisions, and when the people died, they were not allowed to use outer coffins (863). These measures were not the same, but that they both attained supremacy was due to the fact that the times in which they lived were different (864). In the times of Shen-nung, men ploughed to obtain food, and women wove to obtain clothing. Without the application of punishments or governmental measures, order prevailed ; without the ${ }_{\text {p. } 285}$ raising of mailed soldiers, he reigned supreme. $* 8 \mathrm{a}$ After Shen-nung had died, the weak were conquered by force and the few oppressed by the many. Therefore Huang-ti created the ideas of prince and minister, of superior and inferior, the rites between father and son, between elder and younger brothers, the union between husband and wife, and between consort and mate. At home, he applied sword and saw, and abroad he used mailed soldiers ; this was because the times had changed. Looking at it from this point of view, Shen-nung is not higher than Huang-ti, but the reason that his name was honoured was because he suited his time. Therefore, if by war one wishes to abolish war, even war is permissible ; if by killing one wants to abolish killing, even killing is permissible; if by punishments one wishes to abolish punishments, even heavy punishments are permissible (865).

Of old, the one who could regulate the empire was he, who regarded as his first task the regulating of his own people; the one who could conquer a strong enemy was he, who regarded as his first task the conquering of his own people. $*_{8 \mathrm{~b}}$ For the way in which the conquering of the people is based upon the regulating of the people is like the effect of smelting in regard to metal or the work of the potter in regard to clay (866); if the basis is not solid, then people are like flying birds or like animals. Who can regulate these ? The basis of the people is the law. Therefore, a good ruler obstructed the people by means of the law, and so his reputation and his territory p.286 flourished. What is the cause of one's reputation becom ing respected and one's territory wide, so that one attains sovereignty ? (It is because one conquers in war.) What is the cause of one's reputation becoming debased and one's territory dimin ished, so that one comes to ruin ? It is because one is worn out by war. From antiquity to the present time, it has never happened that one attained supremacy without conquest, or that one came to ruin without defeat. If the people are brave, one conquers in war, but if they are not brave, one is defeated in war. If one can unify the people for war, they are brave, but if one cannot unify the people for war, they are not brave. A sage-king obtains the kingship through the efforts of his soldiers. Therefore, he rouses the country 
and charges it with the obligation of military service. If one enters a state and sees its administration, it is strong if its people are of use. How does one know that the people are of use ? If they, on perceiving war, behave like hungry wolves on seeing meat, then they are of use. Generally, war is a thing that people hate; he who succeeds in making people delight in war, attains supremacy. *9a With the people of a strong state, the father, in making a parting bequest to his son, the elder brother to his younger brother, the wife to her husband, all say :

— Do not return unless you win.

And further they say :

- If you incur death by failing in obedience to the law or by transgressing orders, we too shall die.

If in the villages they are governed in an orderly manner, then deserters from the ranks will have no resort and stragglers ${ }_{\text {p.287 }}$ will have nowhere to go. By the order in the ranks they should be organized into bands of five (867); they should be distinguished by badges and controlled by mandates, so that there would be no place for bungling and no danger that exhaustion would arise. Thus the multitudes of the three armies obeyed the mandates like running water (868), and in danger of death they did not turn on their heels.

\# If a state is in disorder, it is not because the law is disorderly, but because its law is not applied. All states have laws, but there are no laws that guarantee that the laws are practised (869). All states have laws that prohibit crime and wickedness, and that punish thieves and robbers, but there are no laws that guarantee that criminals and wicked people, thieves and robbers, are caught. If those who commit crimes and wickedness, theft and robbery, are punished with death, and if, in spite of this, crime and wickedness, theft and robbery do not cease, then it is because they are not always caught (70). If they are always caught, and if, in spite of this, there still remain criminals, wicked

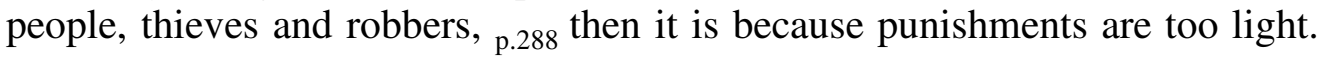
If punishments are light, one cannot exterminate them ; but if they are always caught, then those who are punished will be numerous. Therefore, a good ruler punishes the bad people, but does not reward the virtuous ones, so, without being punished, $* 9 \mathrm{~b}$ the people will be virtuous, and the reason of this is that punishments are heavy. When punishments are heavy, people dare not transgress, and therefore there will be no punishments (871); because none of the people will dare to do wrong, everyone in the whole country will be virtuous, so that without rewarding the virtuous, the people will be virtuous. That the rewarding of the virtuous is not permissible is because it is like giving rewards for not stealing. \# Therefore, a good ruler succeeds in making a man like Chih (872) trustworthy ; how much more, then, a man like Po I (873); An incapable ruler makes a man like Po I mistrustful, how much more a man like Chih ! If conditions are such that one cannot commit crimes, then even a man like Chih will be trustworthy (874); but if conditions are such that it is possible to commit crimes, then even a man like Po I will be mistrustful. 
A state either encourages orderly government, or it encourages disorder. If an intelligent ruler is on top, then ${ }_{\text {p. } 289}$ those whom he appoints will be men of talent, and thus the law will be adhered to by the people of talent. If the law is adhered to by people of talent, then there will be law amongst those below, and the worthless will not dare to commit crimes. This is what I call "encouraging orderly government". But if an unintelligent ruler is on top, then those whom he appoints will certainly be worthless men, so that there will be no clear law in the state and worthless people will dare to commit crimes. This is what I call "encouraging disorder". An army either encourages strength or it encourages weakness. If the people desire naturally to fight and are not left without fighting, it is called "encouraging strength", but if the people naturally *10a do not desire to fight and are left without fighting, it is called "encouraging weakness".

An intelligent ruler does not enrich and honour his ministers in an arbitrary manner. What I mean by riches are not grain, rice, pearls or jade, and what I mean by honour are not rank, position, office or appointments; but I mean the riches and honour of rank and emoluments acquired by actions contrary to the law and which are prompted by selfish interest (875). p.290 \# Generally a ruler of men does not, in virtuous conduct, exceed other men, nor does he do so in knowledge, nor does he surpass others in courage or strength, yet the people, though they may have sages and wise men, they dare not plot against him (876); though they may have courage, dare not kill him ; though they are numerous, they dare not over-rule their lord; though the people may reach a number of many tens of thousands, if heavy rewards are set before them, they dare not contest for them ; if penalties are applied, they dare not resent them. The reason is that there is law. If a state is in disorder, it is because the people often have private opinions of what is their duty; if an army is weak, it is because people often have private shows of bravery (877), and as a result there will be dismemberment. If the roads to the acquirement of titles and emoluments are many, ruin will ensue. In a country, where the desire is to cheapen rank and to make light of emoluments, officials draw their salaries without activity, men have fame, without acquiring it in war, people have respect, without having the rank that entitles them to it, are rich without having emoluments, and are leaders without having office; such are said to be a wicked people.

He who is called a virtuous ruler has no loyal ministers, p.291 and a compassionate father has no filial sons (878). If it is desired $*_{10 \mathrm{~b}}$ to do away with clever talkers, then all should control one another by means of the law (879), and should correct one another by means of mandates. Being unable to do wrong alone, one will not do wrong in the company of others. What is called wealth is to have receipts large and expenditure small. When there is moderation in dress and frugality in food and drink, then expenditure is small. \# When women within and men outside fulfil their duties completely, then receipts are large (880). What is called intelligence is for nothing to escape the sight, so that the multitude of officials dare not commit crimes, nor the people 
dare to do wrong. Thus the ruler of men will repose on a rest-couch and listen to the sound of stringed and bamboo instruments, and yet the empire will enjoy p.292 order. In other words, what is called intelligence is to cause the masses to have no possibility of not working (881). What is called strength is to conquer the empire ; by conquering the empire, all the forces are united, and as a result the brave and strong will not dare to commit any violence, nor will sages and wise men dare to deceive or to be employed on empty grounds. When the multitudes of the empire are united, none will dare not to do what he (the ruler) likes, but all will avoid what he dislikes. In other words, what is called strength is to cause all bravery and force to have no possibility of being used except for the prince's own advantage. If the prince's will is effective, the empire will benefit by it ; if is ineffective, the empire will blame him.

\# Whoever relies on the empire is rejected by the empire; $* 11$ a whoever relies on himself, gains the empire. The one who gains the empire is he, who regards it as his first duty to gain himself; the one who succeeds in conquering a strong enemy is he, who regards it as his first duty to conquer himself (882).

A sage knows the right principles which must be followed, and the right time and circumstances for action. Therefore the rule, which he exercises, always leads to order, the people, whom he employs in war, are always brave, and the commands, which he issues, are always obeyed. In consequence, when his army marches out, it has no equal, and when his commands are issued, the whole empire submits.

p.293 \# A yellow crane flies a thousand $l i$ at one stretch (883), because it is supplied with those qualities which make it fit for flying. The Ch"i-lin and the Lü-êrh (884) cover a thousand $l i$ a day, because they are supplied with the power needed for running. Tigers, leopards, bears and yellow bears are unmatched in fierce fighting, because they have the nature fitted for conquest. A sage views the fundamental elements of government, and knows the principle which must be followed; therefore, his way of directing the people is like directing water from a high to a low place, or like directing fire towards dry things and away from wet ones (85). \# Therefore is it said :

« The benevolent may be benevolent towards others, but cannot cause others to be benevolent; the righteous may love others, but *11b cannot cause others to love.

From this I know that ${ }_{\text {p.294 }}$ benevolence and righteousness are not sufficient for governing the empire. A sage has a nature that insists on good-faith, and he also has a law (method) (886) by which he compels the whole empire to have good-faith. What is called righteousness is when ministers are loyal, sons filial, when there are proper ceremonies between juniors and seniors, and distinctions between men and women, when a hungry man eats, and a dying man lives, not improperly, but only in accordance with righteousness (887). This, however, is the constant condition, when there is law (888). A sage-king does not value righteousness, but he values the law. If with the law one sees to 
it that it is clear, and with commands that they are carried out, then it will be all right. 


\title{
CHAPTER 5
}

\author{
*1a Paragraph 19 \\ Within the Borders
}

p.295 Within the four frontiers, men and women are known by name to their superiors ; at birth they are registered and at death they are erased. Those who have rank ask of those who have no rank to act as bodyguard (889); for each degree the service of one man is requested (890).

When they have no military service, the bodyguards serve their great officers six days in the month; in times of military service, they follow their great officers and are fed by them. The military ranks from the first degree down to the small prefects are called hsiao, t'u, ts'ao, shih; the public ranks from the second degree upwards to the degree of pu-keng are called military officials, $t s u$. In battle five men are organized into ${ }_{\text {p. } 296}$ a squad ; if one of them is killed, the other four are beheaded (891). If a man can capture one head then he is exempted from taxes.

For every five men is there a corporal, t'un-chang, and for every hundred men a centurion, chiang. If in a battle the $*_{11 b}$ centurions and corporals are unsuccessful, they are beheaded; if they are successful, thirty-three heads or more are accounted ample, and to the centurions and corporals one degree in rank is given (892). An officer of 500 men has 50 swordsmen with short weapons (893); an officer of twice 500 men, in commanding them has 100 swordsmen ; a prefect (894) with an income of 1,000 piculs of grain has 100 swordsmen; a prefect with an ${ }_{\text {p.297 }}$ income of 800 piculs of grain has 80 swordsmen ; one with 700 piculs has 70 swordsmen ; one with 600 piculs has 60 swordsmen; the kuo-wei (895) has 1,000 swordsmen, and the general has 4,000 swordsmen. If in a battle, it comes so far that he is killed, then the swordsmen are beheaded. If a man can capture one head, he is exempted from taxes. If in attacking a city or besieging a town they can capture 8,000 heads or more, it is accounted ample ; if in a battle in the open field they take 2,000 heads, it is accounted ample. From the $t s^{\prime} a o$ officers up to hsiao officers, the great general fully rewards the officers in the ranks. He who was formerly kung-shih is promoted to shang-tsao; a shang-tsao to tsan-niao; a tsan-niao to pu-keng; a pu-keng to great officer, ta-fu.

p.298 When an officer is raised to the rank of a district commander, hsien-wei (896), then he is presented with six prisoner-slaves, and provided with 5,000 soldiers and an income of 600 piculs of grain ; ta-fu are raised to the rank of $*_{2 \mathrm{a}} k u o-w e i$; one who was formerly a ta-fu is promoted to kung-ta-fu; a kung-ta-fu to kung-sheng; a kung-sheng to wu-ta-fu, and then receives a tax- 
paying city of 300 families. A former $w u$-ta-fu is promoted to shu-chang : a shu-chang to a tso-keng; one of the three kengs to a ta-liang-tsao (897). In all these cases there is presented a town of 300 families, or the taxes of three hundred families. p.299 Where there is a tax-paying town of six hundred families, an office of vice-chancellor is conferred. Those who ride in the company of the great general are all promoted three degrees. He who was formerly assistant chancellor, when he is accounted to have the full merit, is promoted to the actual chancellorship.

When three heads are captured in battle, they are exposed for three days ; the general confers, in the cases where there is no doubt that it is deserved, the titles of shih and ta-fu in reward. When the heads have been hanging for three days and no titles of shih or ta-fu have been conferred on any one in reward, then they are removed. The four wei of a district are under the critical supervision of a ch'eng-wei. If he succeeds in capturing the head of a man of rank, he receives one ch'ing (98) of land and nine $m u$ of estate, apart from p.300 the conferment of one degree of rank and a bodyguard for each rank (899), and he is allowed to enter amongst the military officers. In case of transgression of the law, then those of higher rank criticize those of lower rank and degree. If a man of high rank has been cashiered, he may not be given as servant (900) to a man of rank. Those holding rank from $*_{2 b}$ the second degree upwards, in case of an offence, are degraded; those holding rank not higher than the first degree, when guilty of an offence, lose it. At the death of a hsiao-fu up to a ta-fu, coffins should be of a different kind (901) for each degree, and the number of trees on the graves (902) should be one for each degree in rank. In p.301 attacking a city or besieging a town, the minister of public works of the state examines critically the size and resources of that city. The kuo-wei assigns the places, dividing the area according to the number of $t^{\prime} u$ and $h s^{\prime a o}$ officers for the attack, and he sets them a time-limit, saying :

- Those who are first will be rewarded as the vanguard and those who hold back will be reprimanded, as being in the rear, and on a second reprimand will be dismissed.

They dig out subterranean passages and pile up fuel; when the fuel has been piled up they set fire to the beams (903). From the corps of sappers, on each side of the town, there are eighteen men. The soldiers from the corps of sappers, if they know how to fight fiercely, although they cannot capture the heads of any men in the ranks (904), are rewarded ${ }_{\text {p.302 }}$ with one degree for each man ; for every one man that is killed, freedom from taxes is given, and for every one man that cannot fight to the death, ten are torn to pieces by chariots (905). Those who make critical remarks are branded or their noses are sliced off under the city wall. The kuo-wei (906), in assigning their various places to all, cause the several detachments to be followed by chung-tsu (907). The general erects a wooden platform, wherefrom, together with the Chief Supervisor of the state and the Chief Secretary, he watches (the battle). *3a Those who enter first are rewarded as men of the vanguard, and those who 
enter last are treated as men of the rearguard (908); as to the corps of sappers, the utmost use is made of their few men; if these few men are not p.303 sufficient, they are supplemented by those who are anxious to receive a rank (909). 


\section{Paragraph 20 Weakening the People}

A weak people means a strong state and a strong state means a weak people. Therefore, a country, which has the right way, is concerned with weakening the people. If they are simple they become strong, and if they are licentious they become weak. Being weak, they are law-abiding; being licentious, they let their ambition go too far ; being weak, they are serviceable, but if they let their ambition go too far, they will become strong (910). Therefore is it said :

« To remove the strong by means of a strong people brings weakness; to remove the strong by means of a weak people brings strength (911).

The people, if they are benefited, are harmonious, and if they are loved, they are serviceable; being serviceable, they receive appointments, and being harmonious, they p.304 are not deficient. Receiving appointments, they will enrich themselves in government positions, the ruler will abandon the law and allow things to be done for the benefit of the people. Thus criminals will be numerous. If the people are poor, they will be rich in strength, and being rich in strength, they become licentious ; being licentious, they will suffer from the parasites. Therefore, if the people are rich and unemployed, they should be made to obtain titles by means of their grain (912) and every one of them will certainly become strong. Then there will be no derogation of agriculture, and $*_{3 b}$ the six parasites will not sprout out, and thus, the state being rich and the people orderly, there will be twofold strength (913).

An army easily becomes weak, but it is difficult to keep it strong. The people enjoy life and feel happy in leisure, but find it difficult to risk death in dangers. If they find it easy, they will be strong. If there are things that one is ashamed of doing, in the case where there are many crimes and few rewards, there is no loss, and in the case where there are many crimes and the suspicion falls on the enemy, ${ }_{\text {. } 305}$ the loss will certainly become gain and the army will become extremely strong and redoubtable. If there are no things which one is ashamed of doing, it is of advantage to use the army, and if one retains the advantage for a long time, one's position will become assuredly supreme. Therefore, if one's army accomplishes what the en emy dares not accomplish, one becomes strong, and if affairs are undertaken which the enemy is ashamed to perform, one obtains advantage.

If there is law and the people are quiet, changes made by the ruler are relegated to the second place, so that affairs become well organized; the country is interested in maintaining peace and quiet, but a ruler in wielding his 
authority and privileged position; thus a ruler values many changes, but the country values few changes.

\# If the profit leaks out through only one outlet, the state will have many products, but if it leaks out through ten outlets, the state will have few products (914). If only one outlet is preserved, there will be orderly government; but if ten outlets are preserved, there will be disorder (915). Orderly government brings strength, but disorder brings weakness; when there is strength, products are imported, but when there is weakness, products are exported. Therefore a state ${ }_{\mathrm{p} .306}$ that imports products is strong and one that exports products is weak (916).

If the people live in humiliation, they value rank; if they are weak, they honour office; and if they are poor, they prize rewards. If the people are governed by means of punishments, they enjoy service, and if the people are made to fight by means of rewards, they scorn death. Therefore if, in war, one's army is efficient, one is called strong (917). *4b If the people have private honours, they hold rank cheap and disdain office, if they are rich, they think lightly of rewards. Orderly people are ashamed of humiliations, and if they are made to fight by means of punishments, they will fight ; if in fighting people are afraid of death and behave in a disorderly manner, the result will be that soldiers and farmers will be lazy and the country weak.

Farming, trade and office are the three permanent functions in a state. Farmers open up the soil, merchants import products, officials rule the people. These three functions give rise to parasites, six in number, which are called : care for old age, living on others, beauty, love, ambition and virtuous conduct. If these six parasites find an attachment, there will be dismemberment (918). If farmers live in affluence, p.307 they seek leisure (919) in their old age; if merchants have illicit profits, there will be beauty and love, and these will harm the means for enforcing the law (920); if officials are set up, but are not utilized, ambition and virtuous conduct will be the end. If the six parasites become a pervading custom, the army will certainly suffer great defeats.

If the law is crooked, order turns into disorder; if reliance is placed on virtue, there is much talking; if government measures are numerous, the state is in disorder; and if there is much talking, the army is weak (221). But if the law is clear, government measures are limited ; if reliance is placed on force, talking ceases; if government measures are limited, the country enjoys orderly administration ; and if talking ceases, the army is strong.

Therefore, in ruling a great country, it becomes small and in ruling a small country, it becomes great (922). If the government takes such measures as the people hate, the people are made weak, and if it takes such measures as the people like, the people are made strong. But a weak people means a strong state, and a strong people means a weak state. $* 4 \mathrm{~b}$ If the government takes such measures as the people like, they are made strong, and if strong people are made even stronger, the army becomes doubly weak; but if the government takes such measures as the people hate, they are made weak, and if weak 
people are made even weaker, p.308 the army becomes doubly strong. Therefore, by strengthening the people, one becomes doubly weak, and perishes; by weakening the people, one becomes doubly strong and attains supremacy. With a strong people to attack the strong brings weakness, whereas on the other side strength remains ; with a weak people to attack the strong brings strength, whereas on the other side strength is removed. If strength remains on the other side, one perishes, but if strength is removed on the other side, one attains supremacy. Therefore, with a strong people to attack the strong brings dismemberment, but with a weak people to attack the strong brings supremacy.

The (923) way in which an intelligent ruler uses his ministers is by always giving them employment for merits, which they have acquired, and by always fully recognizing (224) their ${ }_{\text {p.309 }}$ exertions by rewards, and if a ruler of men makes his people believe in this, as firmly as they do in the sun and moon, then he will have no equal (925).

Now Li Lou could see the tip of an autumn's hair, but he could not transfer his sharp vision to others; Wu Huo could lift the weight of 1,000 chün, but he could not transfer his great strength to others. So sages and men of talent are bound to their personality and nature, which cannot be transferred to others (926).

Now, those who administer affairs in our times, all desire to be more than sages; there is much talk of setting the law on high, but they rule in defiance of the law. This is like carrying a heavy load along a far road without having a horse $_{*_{5} \mathrm{a}}$ or an ox, or like crossing a wide river without having a boat or oars.

Now, to have a numerous population and a strong army is the great capital of an emperor or king, but if he does not have clear laws by which to keep them, he is next-door to peril and ruin. Therefore an intelligent ruler studies the law and thus understands how to bring it about that the people within his borders have no perverse and depraved hearts, that idly-living scholars are pressed into the battle line, and that the ten thousand subjects are alert in ploughing and warfare.

p.310 The people (927) of the state of Ch'u, who were alert and well-balanced and fast as a whirlwind, were, with their iron lances made of the steel from Yüan (928), as sharp as a bee's sting. As armour they wore the skin of sharks (929) and the hide of rhinoceros, which are as strong as metal and stone. The Yang-tzu and the Han Rivers were its moats, and the Ju and the Ying (930) its boundaries, the Forest of Teng (931) was its screen, and the Wall of the Fang Mountains (932) was its frontier. Yet when the army of Ch'in marched on Yen and Ying (933), it took those cities as easily as if it had been merely the shaking of a dead tree. T'ang Mieh (934) met his death at Ch'ui -shê (935), p.311 Chuang Ch'iao (936) rose in the interior, and Ch'u was divided into fi ve parts (937).

This was not because its territory was not large or that the population was not numerous, or that the armour and weapons and resources were not many, 
but the reason, that in fighting it did not win and in defending it was unable to hold its own, was due to the fact that it did not have law (938).

He who dismisses scales and standard weights and manipulates light and heavy ... (939)

*5b Paragraph 21

(Lost) 


\section{Paragraph 22 External and Internal Affairs}

Of the external affairs of the people, there is nothing more difficult than warfare, so an easy law cannot bring them to it. What is called an easy law ? It is when rewards are ${ }_{\text {p.312 }}$ few and authority weak, and when depraved doctrines are not obstructed. What are called depraved doctrines ? They are when sophistry and knowledge are valued, when itinerant politicians receive office, and when scholarship and private reputations are in evidence. When these three are not barred, then people will not fight and affairs fail. For when rewards are few, then there is no advantage in obedience; when authority is weak, then there is no harm in transgression. Therefore depraved doctrines are started in order to mislead the people, and to make them fight while the law is easy, is like setting a cat to bait a rat (940). Is that not impossible ? Therefore, he who desires to make his people fight, sees to it that the law is severe; consequently rewards will be numerous (941), authority will be strict, depraved doctrines will be obstructed, those engaged in sophistry and knowledge will not be honoured, itinerant politicians will not be employed in office, scholarship and private reputations will not be in ${ }_{* 6 \mathrm{a}}$ evidence. If rewards are numerous and authority strict, then people, seeing that in war rewards are many, will forget the danger of death, and seeing their degradation when there is no war, will find life hard. When rewards make them forget the danger of death and strict authority causes them to find life hard, and moreover, depraved doctrines are barred, in this manner meeting the enemy would be like shooting, with a crossbow of a hundred piculs' capacity, a floating leaf. How would it be possible for it not to perish?

Of the internal affairs of the people, there is nothing harder ${ }_{\text {p. } 313}$ than agriculture. Therefore an easy administration cannot bring them to it. What is called an easy administration ? When farmers are poor and merchants are rich, when clever people gain profit and itinerant office-seekers are numerous. So the farmers, in spite of their extremely hard labour, gain little profit, and are worse off than merchants and shopkeepers and all manner of clever people. If one succeeds in restricting the number of these latter, then, even if one wished to, one could not prevent a state from becoming rich. Therefore is it said :

«If one wishes to enrich the country through agriculture, then within the borders grain must be ${ }_{* 6 \mathrm{~b}}$ dear, taxes for those who are not farmers must be many, and dues on market-profit must be heavy, with the result that people are forced to have land. As those who have no land are obliged to buy their grain, grain will be dear, and those who have land will thus profit. When those who have land gain profit, there will be many who will occupy themselves (with agriculture). 
When grain is dear, and the dealing in it is not profitable, while, moreover, heavy taxes are imposed, then people cannot fail to abolish merchants and shopkeepers and all manner of clever folk, and to occupy themselves in the profit from the soil (942). So the strength of the people will be fully exerted in the profit from the soil. Therefore, he who organizes a state, should let his soldiers have the full benefit of the profits on the frontiers, and let the farmers have the full benefit from the profits of the market. If the first happens, the state will be strong, and if the ${ }_{\text {p. } 314}$ second happens, it will be rich. Therefore one who, abroad, is strong in warfare, and at home, is rich in peace, attains supremacy. For if grain is cheap, the value of money is high and cheap grain means poor farmers, and a high value of money means rich merchants ; and if secondary occupations are not forbidden, then ... 


\section{Paragraph 23 \\ Prince and Minister}

In the days of antiquity, before the time when there were princes and ministers (943), superiors and inferiors, the people were disorderly and were not well administered, and so the sages made a division between the noble and the humble; they regulated rank and position, and established names and appellations, in order to distinguish the ideas of prince and minister, of superior and inferior (944). As the territory was $*_{7}$ a extensive, the people numerous and all things many, they made a division of five kinds of officials, and maintained it; as the people were numerous, wickedness and depravity originated, so they established laws and regulations (945) and created weights and measures (946), in order to prohibit them, and ${ }_{\text {p. } 315}$ in consequence there were the idea of prince and minister, the distinctions between the five kinds of officials, and the interdicts of the laws and regulations, to which it was necessary to pay heed. If, when occupying the position of prince, one's mandates are not carried out, one is in peril ; when there is no constancy in the distinctions between the five kinds of officials, there is disorder; when laws and regulations have been set up and yet private notions of virtue are practised, then people do not stand in fear of punishment. When the prince is respected, his mandates are carried out; when officials have been well-trained, there is constancy; and when laws and regulations are clear, people stand in fear of punishment. If laws and regulations are not clear, then it is impossible to obtain from the people the observance of mandates. If the people do not observe the mandates, but you want the prince to be respected, even a man with the wisdom of Yao and Shun would not be able to govern well. The way in which an intelligent prince administers the empire is to do so according to the law, and to reward according to merit. It is the hankering for rank and emoluments that prompts people to fight energetically and not to shun death. The way in which an intelligent prince administers a state is to award soldiers, who have had the merit of making decapitations or of capturing prisoners, with such rank as will really give honour, and to grant them such emoluments as will be sufficient for them to live on and $*_{7 b}$ to farmers, who do not leave their ground, sufficient to ${ }_{\text {p. } 316}$ nourish both their parents and to keep their family affairs in order. Thus soldiers in the army will fulfil their duty even to death, and farmers will not be negligent.

But the princes of the present time do not act thus. They relax the law and keep to knowledge (947); they turn their backs on merit and keep to people of reputation. Therefore, soldiers do not fight and farmers are migratory.

\# I have heard that the gate through which the people are guided depends on where their superiors lead. Therefore, whether one succeeds in making people farm or fight, or in making them into travelling politicians, or in 
making them into scholars, depends on what their superiors encourage. If their superiors encourage merit and labour, people will fight ; if they encourage the Odes and Book of History, people will become scholars. For people's attitude towards profit is just like the tendency of water to flow downwards (948), without preference for any of the four sides. The people are only interested in obtaining profit, and it depends on what their superiors encourage, what they will do. If men with angry eyes, who clench their fists (949) and call themselves brave, are successful; if men in flowing robes, who idly talk, are p.317 successful ; if men who waste their time and spend their days in idleness, and save their efforts for obtaining benefit through private channels (950), are successful - if these three kinds of people, though they have no merit, all obtain respectful treatment, then people will leave off farming and fighting and will do this : either they will extort it by discussions and suggestions, or they will ask for it by practising flattery, or they will struggle for it by acts of bravery. Thus $* 8$ a farmers and fighters will dwindle daily, and itinerant office-seekers will increase more and more, with the result that the country will fall into disorder, the land will be dismembered, the army will be weak and the ruler debased. This would be the result of relaxing laws and regulations and placing reliance on men of fame and reputation. \# Therefore is an intelligent ruler cautious with regard to laws and regulations; he does not hearken to words which are not in accordance with the law; he does not exalt actions which are not in accordance with the law; he does not perform deeds which are not in accordance with the law. But he hearkens to words which are in accordance with the law; he exalts actions which are in accordance with the law; he performs deeds which are in accordance with the law. Thus the state will enjoy order, the land will be wide, the army will be strong, and the ruler will be honoured. This is the climax of good government, and it is imperative for a ruler of men to examine it. 


\section{Paragraph 24 \\ Interdicts and Encouragements}

p.318 The method by which a ruler of men prohibits and encourages is by means of rewards and penalties. Rewards follow merit and penalties follow crime; therefore is it necessary to be careful in appraising merit and in investigating crime. Now, rewards exalt and punishments debase, but if $* 8 \mathrm{~b}$ the superiors have no definite knowledge of their method, it is no better than if they had no method at all. But the method for right knowledge is power (951) and figures (252). \# Therefore, the early kings did not rely on their strength but on their power (shih); they did not rely on their belief but on their figures. Now, for example, a floating seed of the p'eng plant (953), meeting a whirlwind, may be carried a thousand $l i$, because it rides on the power (shih) of the wind. If, in measuring an abyss, you know that it is a thousand fathoms deep, it is owing to the figures which you find by dropping a string. So by depending on the power (shih) of a thing, you will reach a point, however distant it may be, and by keeping the proper figures, you will find out the depth, however deep it may be. Now, for example, in the darkness ${ }_{p .319}$ of the night, even a Li Lou (954) cannot see a great mountain forest, but in the clear morning light, with the brilliant sun, he can distinguish the flying birds above, and below he can see an autumn hair, for the vision of the eye is dependent on the power of the sun. \# When the highest condition of power (shih) is reached, things are arranged without a multitude of officials and are made fitting by expounding the system (955). But nowadays, reliance is placed on a multitude of offices and a host of civil servants, and in the official bureaux assistants and controllers (956) are appointed. Now, the idea of appointing these assistants and controllers is indeed to prevent men (957) from making profit, but these assistants and controllers themselves also desire to make profit. How then can they prevent others from doing so ! Therefore, if one relies on assistants and controllers for one's administration, then will it be an administration that can barely maintain itself.

It is not thus, if one understands "system" ; one separates their power (shih) and puts checks on their conduct. $*{ }_{9}$ Therefore is it said :

«\# If the conditions of power (shih) are such that it is difficult to conceal anything, then even a man like Chih does no wrong (958).

Therefore, the early kings ${ }_{\text {p.320 }}$ prized power (shih). Some say :

- A ruler of men holds a nominal right of consent, post factum ; then things are controlled and examined, and by this control wickedness is discovered.

I do not think that this is right. For officials exert sole authority and take decisions a thousand $l i$ away (from the ruler). In the twelfth month, to confirm 
it, they make a report, in which the affairs of the whole year have separate entries; but as the ruler gives but one hearing, although he sees doubtful cases, he cannot determine whether an official is capable or otherwise ....

For example, if objects come near, the eye cannot but see them; if words are insistent, the ear cannot but hear them; for if objects approach, they alter in appearance, and if words draw near, they form coherent speech. \# So with the organization in a well-governed state, people cannot escape punishment any more than the eyes can hide from the mind what they see. But in the disorderly states of the present time, it is not thus : reliance is placed on a multitude of offices and a host of civil servants, but however numerous the civil servants may be, their affairs are the same and they belong to one body. Now, those whose affairs are the same and p.321 who belong to one body, cannot control one another. But by making their interests different and their disadvantages dissimilar, the early kings created guarantees. \# Therefore, in a condition of complete good government, husband and wife and friends cannot abandon each other's evil, cover up wrong-doing and not cause harm to relatives ; nor can the men from the people mutually conceal each other from their ${ }^{*}$ b superiors and government servants. That is because, although their affairs are connected, their interests are different (959). But nowadays a Tsou and a Yü cannot control each other, because their business is the same and their interests are also similar . . Suppose that horses could speak, then a Tsou and a Yü (960) would have no chance of escaping what they find hateful ; that is because their interests would be different (961). When interests are connected and what they hate is the same, then a father cannot reprimand his son, nor a prince his minister. The relation of government servants to other government servants is this, that their interests are connected and what they p. 322 hate is the same. Now, the early kings made it a principle that those whose business was connected, should have different interests. \# Though the people may hide things from their ruler, there is no harm done in thus covering them up, nor can there be advantage in having virtuous men or harm in having worthless ones. The system, therefore, of good government is to neglect the virtuous and to abolish the wise. 


\section{Paragraph 25 \\ Attention to Law}

Generally, there is no one in the world, who does not base order on the causes of disorder. Therefore, to a limited degree of order corresponds a limited degree of disorder, and to a great degree of order corresponds a great degree of $* 10$ a disorder: There is no ruler of men who can give order to his people for all time, nor is there a country in the world that has not known disorder. What do I mean by saying that one bases order on the causes of disorder? Raising virtuous and capable men is the cause of bringing order into the world, but it is also the cause of order becoming disorder. Those whom the world calls virtuous are men whose words are upright. the reason why they are regarded as upright in words is due to their partizans. Hearing their words, one takes them to be capable, and on asking their partizans, one thinks that they are indeed so. Therefore, one prizes them without waiting for them to acquire actual merit, or one punishes them without waiting for them to commit crimes. In these circumstances, vile officials are given precisely the p.323 opportunity to accomplish their wicked and dangerous acts, and small-minded men have an opportunity to apply their dexterous and crafty tricks (962). If in the beginning a basis for wickedness and craftiness is provided for officials and people, then if finally one tries to make them correct and guileless, even (a great sage like) Yü could not succeed in causing as many as ten men to be like that. How then could an ordinary ruler manage the people of the whole country in this way?

Those people who form parties with others do not need Us (963) for obtaining success, and if superiors pull one way with the people, then the latter will turn their backs on the ruler's position and will turn towards private connections. When this is the case, the prince will be weak and his ministers strong, and if the ruler does not understand this, then if the country $*_{10 \mathrm{~b}}$ is not annexed by the feudal lords, it will be robbed by the people (964).

Both stupid and wise will, alike, try to acquire that power of eloquence, and if scholars study with those eloquent speakers, then people will lose touch

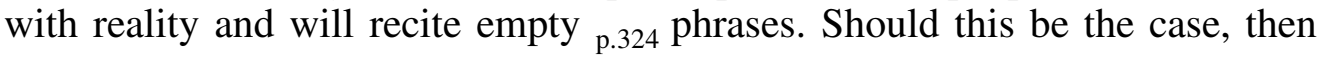
their strength will decrease and wrong-doing will increase ; and if the prince does not understand it, in battle he will lose his generals, and in defence his cities will certainly be sold. Therefore, if there is an intelligent ruler or a loyal minister born in this age who wishes to lead his country, then he should not for one moment be forgetful of the law, but he should conquer and destroy cabals, control and abolish eloquence, and relying on the law, the country will enjoy order. If a condition is brought about where, for government servants, there is no other standard maintained than the law, then, however tricky they may be, they will be unable to commit wickedness, and if, for the people, a 
condition is brought about where there is no other way of exerting their capacities than in war, then, however great the danger may be, no deceit will be possible. Indeed, if people control each other by law and recommend each other by following systematic rules, then they cannot benefit each other with praise nor harm each other with slander. If the people see that there is no benefit in praising each other, they will become used to loving each ${ }_{\text {p. } 325}$ other without flattery, and if they see that there is no harm in slandering each other, they will become used to hating each other without injuring each other. If the love of men does $* 11$ a not mean flattery, and the hatred of men does not mean causing injury, then both love and hatred will be pure, which is the highest degree of order. Therefore do I say: 'If one relies on law, the country will enjoy order".

A country of a thousand chariots is able to preserve itself by defence, and a country of ten thousand chariots is able to round itself off by fighting even (a bad ruler like) Chieh would not be able to twist one word of this statement in order to subdue his enemies (965); and if, abroad, one is incapable of waging war, and at home one is incapable of defence, then even (a good ruler like) Yao could not pacify, for any misbehaviour (966), a country that (normally) would be no match. Looking at it from this point of view, that through which the country is important and that through which the ruler is honoured is force. Force being the basis of both, how is it then that no ruler on earth succeeds in developing force ? Bring about a condition where people find it bitter not to till, and where they find it dangerous not to fight. These are two things which filial sons, though they dislike them, do for their fathers' sake, and loyal ministers, though they dislike them, do for their sovereign's sake. Nowadays, if you wish to stimulate the multitude of people to make them do what ${ }_{\text {p. } 326}$ even filial sons and loyal ministers dislike doing, I think it is useless unless you compel them by means of punishments, and stimulate them by means of rewards. But nowadays, the ordinary types of ruler all neglect laws and measures, and rely on sophistry and cleverness ; they push back men $*_{11 b}$ of merit and force, and advance those of benevolence and righteousness, with the result that people do not devote themselves to agriculture and warfare. If such people do not turn their energies to agriculture, at home their food-supply will be exhausted, and if they do not turn to their duty in warfare, abroad the army will be weak ; then, though one may have a territory of ten thousand $l i$, and a million armed men, it will be the same as a plain that has to depend on its own resources. Furthermore, the early kings were able to command their people to walk on bare swords and to suffer arrows and stones, and the people were willing to do so, not because they liked learning such things, but because they escaped (967) harm thereby. Therefore my teaching is to issue such orders that people, if they are desirous of profit, can attain their aim only by agriculture, and if they want to avoid harm, can only escape it by war. There will be no one within the borders who will not devote himself at first to ploughing and fighting, in order thereby later to obtain that which gives him pleasure. Therefore, though the territory may 
be small, the produce will be plentiful, and though the population may be sparse, the army will be strong. If one ${ }_{p .327}$ can achieve these two things within the territory, then the road to becoming a lord-protector or king of the whole empire is fully prepared. 


\section{Paragraph 26 The Fixing of Rights and Duties}

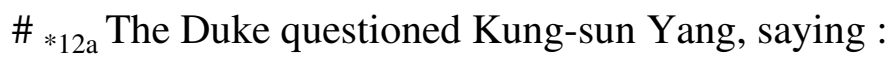

- Supposing that one established laws and mandates today, and wished that, tomorrow, all government servants and people, throughout the empire, should understand them clearly and apply them, so that all should be as one, and should have no selfish intentions - how can one bring this about?'

Kung-sun Yang replied :

- There should be instituted, for the laws, government officers who are able to understand the contents of the decrees, and who should be the regulators of the empire. Then they should memorialize the Son of Heaven, whereupon the Son of Heaven would personally preside over the law and promulgate it. All should then issue to their inferiors the mandates they have received, and the law officers (968) should preside personally over the law and promulgate it. When people venture to neglect practising the items (969) named in the promulgations of the officers presiding over the law, then each one is punished according to p. $_{328}$ the item in the law which he has neglected. In the eventuality of these officers, who preside over the law, being transferred or dying, students should be made to read the contents of the law and a standard of knowledge should be fixed for them, so that, within a certain number of days, they should know the contents of the law, and for those students who do not reach the standard, a law is made for punishing them. Should any one dare to tamper with the text of the law, to erase or add one single character, or more, he shall be condemned to death without pardon. Whenever government officials (970) or people have questions about the meaning of the laws or mandates, to ask of the officers presiding over the $*_{12 \mathrm{~b}}$ law, the officers should, in each case, answer clearly according to the laws and mandates about which it was originally desired to ask questions, and they should, in each case, prepare a tablet of the length of 1 foot 6 inches, on which should be distinctly inscribed the year, month, day and hour (971), as well as the items of law about which questions were asked, for the information of the government officials or of the people. Should the officers who preside over the law not give the desired information, they should be punished according to the contents of the law, that is, they should be punished ${ }_{\text {p.329 }}$ according to the law about which the government officials or people have asked information. The 
officers, presiding over the law, should forthwith give to those government officials who ask information about the law, the left half of the document and they themselves should store carefully the wooden bindings with the right half of the document, keep them in a room and seal them with the seal of the chief of the office of laws and mandates. Later, on the death of the officer, affairs should be transacted according to these files. All the laws and mandates should be put together as a set, one set being kept in the palace of the Son of Heaven. Forbidden archives (972) should be built for the laws, which are locked with lock and key to prevent admittance, and are sealed up; herein should be stored one set of the laws and mandates. Inside the forbidden archives they should be sealed with a seal forbidding their opening. Whoever ventures unauthorisedly to break the seals of the forbidden archives, or to enter the forbidden archives, to inspect the forbidden laws and mandates, or to tamper with one or more characters of the forbidden laws, shall, in any of these cases, be guilty of death without pardon. Once a year laws and mandates shall be received for prohibitions and orders to be issued. *13a The Son of Heaven shall set up three law officers, one in the ${ }_{\text {p.330 }}$ palace, one in the office of the Yü-shih, together with a government official, and one in the chancery of the Ch'eng-hsiang (973). In the various prefectures and sub-prefectures of the feudal lords, shall be instituted one law officer, together with government officials, all of whom shall be similar to the law officers in Chin (974). Thus the prefectures and subprefectures and the feudal lords shall all alike receive a knowledge of the laws and mandates in the archives, and moreover the afore-mentioned government officials and people, who are desirous of knowing the law, shall all address their inquiries to these law officers. Thus there shall be no one among the government officials and people of the empire who does not know the law, and as the officials are clearly aware that the people know the laws and mandates, they dare not treat the people contrary to the law, nor dare the people transgress the law, as they would come into conflict with the law officers. If in their treatment of the people the government officials do not act according to the law, the former should inquire of the law officer, who should at once inform them of the punishment (for the illegal action in p.331 question) fixed by the law. The people should then at once inform the government officials, formally, of the law officer's statement. Thus the government officials, knowing that such is the course of events, dare not treat the people contrary to the law, nor do the people dare infringe the law. In this way, government officials and the people of the empire, however virtuous or good, however sophistical or sagacious they may be, cannot add one word to twist the law ; nor, though they may have a thousand pieces of gold, can 
they use one $*_{13 b}$ twenty-fourth of an ounce of it for such a purpose. Thus the knowing and crafty ones, as well as the virtuous and capable, will all force themselves to behave well and will do their best to restrain themselves and to serve the public weal. When people are stupid, they are easy to govern (975). All this originates from the fact that the law is clear, easy to know, and strictly applied.

Law is the authoritative principle (976) for the people, and is the basis of government; it is what shapes the people. Trying to govern while eliminating the law is like a desire not to be hungry while eliminating food, or a desire not to be cold while eliminating clothes, or a desire to go east while one moves west. It is clear enough that there is no hope of realizing it.

That a hundred men will chase after a single hare that runs away, is not for the sake of the hare ; for when they are sold ${ }_{\text {p.332 }}$ everywhere on the market, even a thief does not dare to take one away, because their legal title (977) is definite. Thus if the legal title is not definite, then even men like Yao, Shun, Yu or T'ang would all rush to chase after it, but if the legal title is definite even a poor thief would not take it (978). Now if laws and mandates are not clear, nor their titles definite, the men of the empire have opportunities for discussion ; in their discussions they will differ and there will be no definiteness. If above the ruler of men makes laws, but below the inferior people discuss them, the laws will not be definite and inferiors will become superiors. This may be ${ }_{* 14 \mathrm{a}}$ called a condition where rights and duties are indefinite. p.333 When rights and duties are indefinite, even men like Yao and Shun will become crooked and commit acts of wickedness, how much more then the mass of the people! This is the way in which wickedness and wrong-doing will be greatly stimulated, the ruler of men will be despoiled of his authority and power, will ruin his country and bring disaster upon the altar of the soil and grain (979).

\# Now the former sages made writings and transmitted them to later generations, and it is necessary to accept these as authoritative, so that one may know what is conveyed by established terminology (980). Should they not be accepted as authoritative and should people discuss them according to ideas of their own mind, then until their death they will not succeed in understanding the terminology and its meaning. Therefore did the sages set up officers and officials for the laws and mandates, who should be authoritative (981) in the empire, in order to define everyone's rights and duties, so that these being definite, the very crafty would become faithful and trustworthy, and the people would all become honest and guileless, each one restraining himself. \# For indeed, the defining of everybody's rights and duties is the road that leads to orderly government, but the not defining of everybody's rights and duties is the road that leads to disorder. So where there 
is a tendency towards order, there cannot be ${ }_{\text {p.334 }}$ disorder, and where there is a tendency towards disorder, there cannot be order. \# Indeed, where there is a tendency towards disorder and one governs it, the disorder will only increase, but where there is a tendency towards order and one governs it, there will be order. Therefore, the sage kings governed order and did not govern disorder.

Indeed, subtle and mysterious words, which have to be $* 14 \mathrm{~b}$ pondered over (982), cause difficulty even to men of superior knowledge. There may be one case in ten millions, where the directing guidance (983) of the law is not needed and yet it is correct in everything. Therefore, a sage governs the empire for the ten million cases. For, indeed, one should not make laws so that only the intelligent can understand them, for the people are not all intelligent ; and one should not make laws so that only the men of talent can understand them, for the people are not all talented. \# Therefore did the sages, in creating laws, make them clear and easy to understand, and the terminology correct (984), so that stupid and wise without exception could understand them ; and by setting ${ }_{\text {p. } 335}$ up law officers, and officers presiding over the law, to be authoritative in the empire, prevented the people from falling into dangerous pitfalls. So the fact that when the sages established the empire there were no victims of capital punishment, was not because capital punishment did not exist, but because the laws which were applied were clear and easy to understand. They set up law officers and government officials to be the authority, in order to guide them ; and they knew that if the ten thousands of people all knew what to avoid and what to strive for, they would avoid misfortune and strive for happiness, and so restrain themselves. Therefore, an intelligent prince follows the existing conditions of order and so makes the order complete, with the result that the empire will enjoy great order.

Paragraph 27

(Lost)

Paragraph 28

(Lost)

Paragraph 29

(Lost) 


\section{N O T E S}

(101) I have preferred to render Shang-chün by the Lord Shang or the Lord of Shang, rather than by the Prince of Shang, as he is sometimes called; because I believe that the former expression is a better equivalent of the feudal-rank which he held.

(102) T'u-shu-chi-ch'eng, Li-hsüeh-hui-pien, Ching-chi-tien, ch. 441.tzu

(103) Chang-shih-ts'ung-shu, book Chien-lun, ch. 9, pp. 4a-7b.

(104) Yin-ping-shih-ts'ung-chü (1916), I, book Shih-chuan-chin-i, ch. Kuan-tzu-chuan, Appendix, pp. 1-47.

(105) Ancient Chinese Political Theories (1928).

(106) Materialy po kitajskoj filosofii, vvedenie škola fa (1912).

(107) Geschichte der alten Chinesischen Philosophie (1927).

(108) Ancient Chinese Political Theories (1928).

(109) Cf. Wang Shih-jun (see infra), p. 1 of his Introduction.

(110) Cf. p. 139.

(111) La conception de la loi et les théories des légistes à la veille des Ts'in, par J. Escarra et R. Germain (Pékin, 1926). For further literature, on the Law School, cf. the note on p. XXI of that work.

(112) References to ancient Chinese books, throughout this work, are to the following editions :

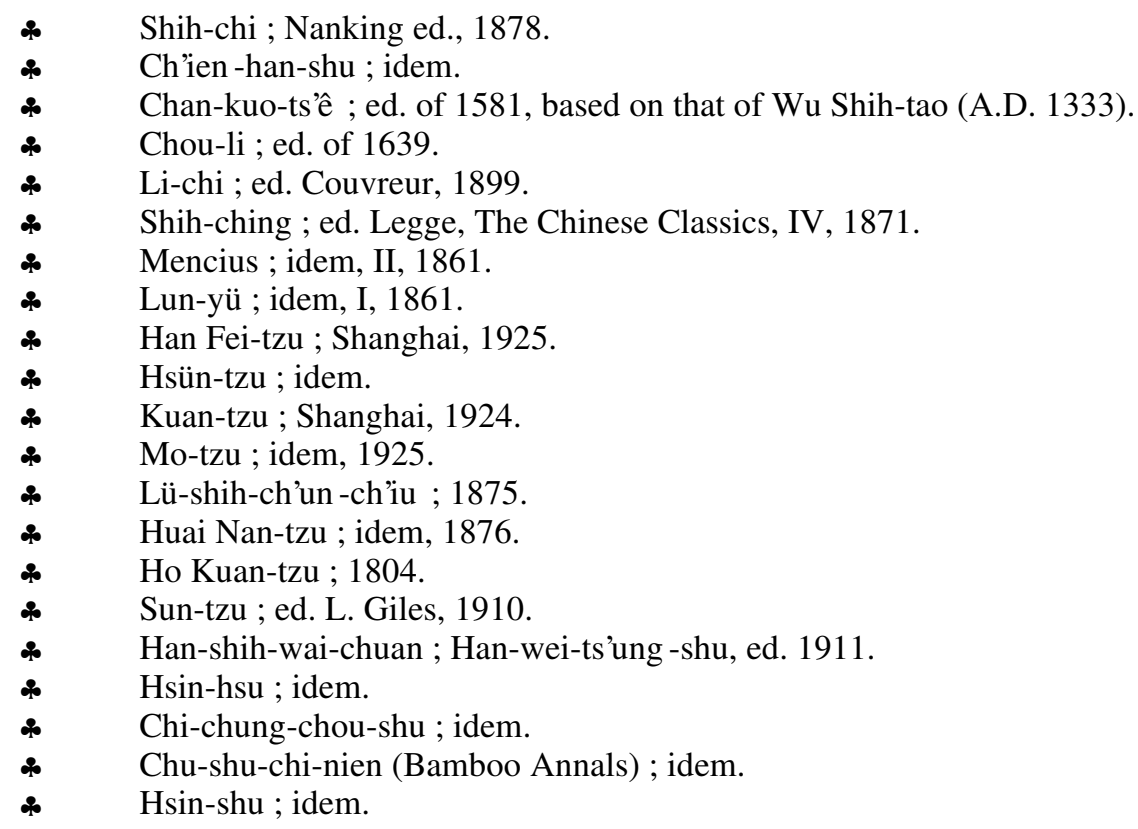


(113) 255-206 B.C.

(114) Cf. Chavannes, Mém. Hist., III, p. 25.

(115) 198-165 B.C.

(116) [], forming part of the Hsin-shu, published in the Han-wei-ts'ung-shu. Cf. on him Chavannes, op. cit., I, Introduction, pp. CLVIII et sqq.

(117) The Hsiao pass was one of the «nine barriers » of Ch'in ; it was situated $50 l i$ north of the present Yung-ning-hsien in Honan. The Hsien or Hsien-ku pass lay south of Ling-pao-hsien in the same province.

(118) i.e. approximately the present provinces of Shensi and Kansu.

(119) Chavannes, op. cit. II, p. 225, translating this part, in a footnote says by mistake that the Lord of Shang is the same as Yuan Ang, who is an entirely different person (cf. ibid., p. 499).

(120) i.e. laws and rules.

(121) connected transversally. Heng «transversal» is technically used for Ch'in's policy of expansion from west to east, whereas tsung « longitudinal » indicates the alliance of Ch'i and Ch'u and the states lying between them from north to south, and which was directed against Chin.

(122) Without any difficulty.

(123) Shih-chi-chi-chieh, collected explanations of the Shih-chi by P'ei Yin. This scholar, who made use of a great number of now lost sources, wrote the oldest commentary on the Shih-chi. He had some high literary dignity between 465-472. Cf. on him Chavannes, Mém. Hist., I, Introduction, p. CCXI.

(124) This sentence has, with slight alterations, been taken from Chia I's essay on the "Mistakes of Ch"in" ; cf. p. 2.

(125) i. e. Wei's territory west of the Yellow River.

(126) i. e. the territory comprised by the present Yen-an-fu and Yu-lin-fu in Shensi.

(127) Ed. Legge, p. 331. The lines describe the perfection of the royal path.

(128) Shih-ching, ed. Legge, p. 353.

(129) Compiled according to the Shih-chi by order of King Wei of Chi (378-343), from a number of ancient writings, elucidating the principles of T'ien Jang -tsu Ssu-ma Jang-tsu, the military director of that state under Duke Ching (547-490).

$(\underline{130})$ The legendary director of husbandry under the Emperor Yao.

(131) i.e. Hsün-tzu.

(132) Duke Huan, acting under threat of being murdered at the moment when he was concluding a covenant with $\mathrm{Lu}$ at Ko (in Shantung), promised to return to $\mathrm{Lu}$ all the land that he had conquered in the previous war. On the advice of Kuan Chung he kept his promise.

(133) The Marquis Wen of Chin having laid siege to the city of Yüan, and having ordered the soldiers to be provided with three days provision, said that if within three days Yüan would not surrender, he would raise the siege. On the third day he was informed that the city would surrender next evening. In spite of this report Marquis Wen retired, saying :

«Good faith is the precious jewel of a state, and what the people depend upon. If I get Yüan and lose my good faith, of what protection could the people be assured ? My loss would be much greater than my gain.

Cf. Ch'un-ch'iu, $25^{\text {th }}$ year of Duke Hsi (ed. Legge, p. 196). [css : Couvreur, Tso tchoan, t. I, pp. 372-373.] 
(134) Appellation Hu Yen, who was the maternal uncle of Marquis Wen and was one of his councillors.

(135) See the Biography, infra, p. 21.

(136) This is a reference to his first conversations with Duke Hsiao, cf. p. 11.

(137) Duke Shao, one of the principal adherents of Wen-wang, the ancestor of the Chou dynasty.

(138) Shih-ching, ed. Legge, p. 26. [css : Couvreur, Che king, I, II, V]. The Ode runs :

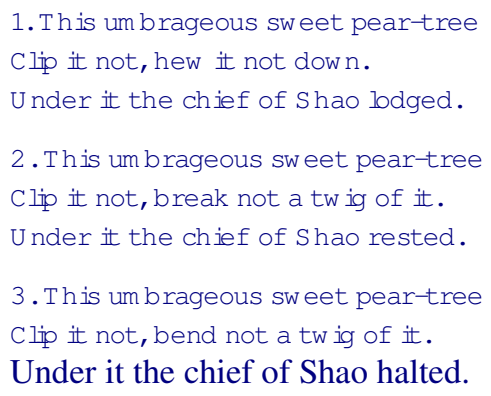

(139) Kuan-tzu, as a reward, obtained the city of P'ien, with three hundred families, which was taken from the chief of the Po family. So generally, however, were his merits recognized, that there was no protest. Cf. Lun-yü, XIV, 10 (Legge, p. 142) [css : Couvreur, Louen-yu] ; also Hsün-tzu, chap. 3, par. 7, p. 34. Dubs, p. 83.)

(140) A $p u$, pace (i.e. two of our paces) is here used as a fixed measure, consisting of six ch'ih, feet, used in measurements of land. One mu was 100 sq. pu. Cf. Ch'ien-han-shu, chap. 24, p. $1 \mathrm{~b}$; also Chavannes, Mém. Hist., II, p. 130. Forke, Geschichte der alten Chinesischen Philosophie, p. 453, misunderstands this phrase : «Wer gröszere Doppelschritte machte als 6 Fusz, erhielt eine leichte Strate. Vermuthlich galt das übermässige Ausschreiten als unschicklich oder als Zeichen besonderer Arroganz. »

(141) Forke, op. cit., p. 453, misinterprets this : «Als Shang Yang einmal am Ufer des Wei von Verbrechern sprach, soll nach der Tradition das Wasser des Flusses sich plötzlich blutrot gefärbt haben, ein Hinweis ant seine Blutgesetze. »

(142) By Ssu-ma Ch’ien, about 145 -86 B.C.

(143) Composed some time in the third century B.C.

(144) Ch. 68.

(145) A name often given to illegitimate descendants.

(146) Chan-kuo-ts'ê, ch. 7, p. 5, relates that this man commanded the army of Wei in the battle near the River Kuai, where Han and Chao were beaten. For Tso it writes Ts'o. This battle was in 362 B.C. In the same year Ch'in gained a victory over Wei at Shao-liang, where according to the Wei Annals of the Shih-chi (cf. Chavannes, Mém. Hist., V, p. 152), the general of Wei, Kung-sun Ts'o, was taken prisoner. This is confirmed in the Ch'in Annals (Chavannes, op. cit., II, p. 60). As Kung-shu and Kung-sun are really designations of members of the princely family, this must be the same man. The Chao Annals (Chavannes, op. cit., V, p. 59) say that in the battle, Ts'o, the crown prince, was taken prisoner and the chronological tables merely say : «Our (i.e : Wei's) crown prince was taken prisoner ». There is surely a qui-pro-quo here. Probably the fact that some relation of the ruling house was made prisoner was eaaggerated into the report that it was the crown prince ; more especially is this likely, as he was actually captured by Ch'i in 341 (cf. Chavannes, op. cit., V, p. 157).

(147) The $s h u-t z u$ were charged with the education of the sons from the princely families. 
(148) 370-319 B.C. (the Shih-chi errs in making his reign end in 335 ; cf. Chavannes, Mém. Hist., V, p. 158, and Maspero, Chine Antique, pp. 397 and 402) ; as Hui did not bear the title of king before 335 , there is an anachronism here.

(149) i.e. who should become chaneollor ?

(150) The same story is given, in simpler form, in the Chan-kuo-ts'ê, ch. 7, pp. 5b, 6a, see below, p. 31, and in the Lü-shih-ch'un-ch'iu, ch. 11, p. 13, which was written in 238 B.C. The latter text runs :

«When Kung-shu Tso of Wei was ill, King Hui went to inquire after his illness and said :

- Your illness is serious ; what provision should be made in future for the Altar of the Soil and Grain?

Kung-shu replied, saying :

- I should wish that Your Majesty would, in state affairs, listen to my yü-shu-tzu Yang. But if Your Majesty cannot decide to listen to him, you should prevent him from leaving the country.

The King did not reply, but when he left, he said to his entourage :

- Is it not déplorable? A man of Kung-shu's wisdom to tell me to-day that I should, in state affairs, listen to Yang - how stupid !

Now when Kung-shu had died, Kung-sun Yang travelled westward to Ch'in. Duke Hsiao of Ch'in listened to his counsel and so Ch'in became strong and Wei became weak.

(151) For this mandate, cf. Chavannes, op. cit., II, pp. 62, 63. Duke Mu (659-621) had made large conquests, in the east obtaining from Chin the territory which it had held west of the Yellow River, known as Ho-hsi. Under his successors, Ch'in lost this again, but it remained the fixed policy of its rulers to extend its frontiers to the Yellow River. Duke Hsiao reigned from 361 to 338 ; as Ssu-ma Chien mentions the mandate right at the beginning of his reign, we may place Kung-sun Yang's arrival in Ch'in in 361 B.C.

(152) A member of a branch of the ruling house of Ch'u.

(153) For the following speeches, cf. pp. 167-175.

(154) This was in 359 B.C.. ; cf. the Annals, Chavannes, op. cit., II p. 64 :

«In the third year, Wei Yang persuaded Duke Hsiao to alter the laws and to reform the penalties; at home, to give special attention to agriculture, and abroad, by a system of rewards and punishments, to encourage people to fight to the death. Duke Hsiao approved, but Kan Lung, Tu Chih and others were opposed to it, and they combined together to fight these plans. Finally, however, Yang's laws were put into practice ; the people suffered from them, but alter three years, they found them convenient. Thereupon, Yang was appointed Tso-shu-chang. These things will be found in the story of the Lord of Shang.

(155) This was the tenth degree in the ranks instituted by the Ch'in's (cf. p. 62). From the Annals (cf. note 154) it will be seen that this appointment followed in 356 B.C. Maspero, $\underline{L a}$ Chine Antique, p. 379, also dates it in 356 ; Forke, Geschichte der alten Chin. Philosophie, p. 450, errs in saying that in 361 he was made secret councillor (Geheimer Rat) ; Ivanov, op. cit., p. LVI, wrongly gives 350 as the date when Wei Yang entered the service of Duke Hsiao.

(156) Cf. the Book, par. 18, p. 287 ; par. 24, p. 321 ; and Han Fei-tzu, par. 13, p. 21 ; par. 43, p. 13 ; also below, pp. 58 et seq. 
(157) i.e. married sons were regarded as heads of different families. Cf. note 165 . Wieger, Textes Hist., p. 198 [p. 162, éd. 1929], mistranslates: «Toute famille ayant plus de deux enfants mâles, recevait une prime. »

(158) Cf. p. 62.

(159) Both individuals are otherwise unknown.

(160) Cf. the account of the Chan-kuo-ts'ê, below, p. 32, where the same standing phrase is used. The same thing is said in the description of the beneficial results of Confucius' administration in Lu. Cf. Chavannes, op. cit., V, p. 327.

(161) A high military rank. This appointment took place in 352 B.C.. Cf. Chavannes, op. cit., II, pp. 64, 65 .

(162) An-i is to the north of the sub-prefecture of Hsia in Chieh, in the present province of Shansi. It was the capital of Wei, down to 340. No mention is made of this event in the Wei Annals ; the Bamboo Annals, which were written in Wei before 299 B.C., say that in $365 \mathrm{An}-\mathrm{i}$ ceased to be the capital (cf. note 176). The way in which its capture is here mentioned certainly does not give the impression of such an important event as the taking of a capital. Two years before this campaign, in 354, Ch'in had gained another victory over Wei and had regained the town of Shao-liang, won in 640 by Duke Mu, but subsequently lost in 615 .

(163) 350 B.C. ; cf. Chavannes, op. cit., II, p. 65. Hsien-yang, in the prefecture of Hsi-an, in modern Shensi, remained the capital to the end of the Ch'in dynasty. The pillars mentioned here were placed in front of the gate and mandates were affixed to them...They were called [] because this was the name of the old capital of Chin, of which Wei was one of the three succession states, and it therefore commemorated the victories over Wei. Cf. Maspero, $\underline{o p}$. cit., p. 382.

(164) Yung, corresponding to Feng-hsiang-fu in modern Shensi, was the capital of Ch'in from 677 to 383 ; but Duke Hsien had already transferred the seat of government to Yo-yang, $15 \mathrm{li}$ north of Lin-t'ung -hsien, in Hsi-an-fu, Shensi. Maspero, op. cit., p. 381, following a mistake of Chavannes, corrected by himself (op. cit., II, p. 614), writes Li-yang.

(165) This was a further step in the direction of breaking up the patriarchal family-system, already initiated by the order that double taxes had to be paid where there were two men or more in a household. Cf. note 157.

(166) The hsien was originally larger than the chün, but the Ch'in reversed the relationship between these two terms. A hsien, under the Ch'in and Han dynasties, was the largest provincial unit within the chün (which may be compared with the modern sheng) and corresponds therefore with the later $f u$ rather than with the later hsien. Cf. Chavannes, op. cit., II, pp. 530, 531.

This measure aimed at centralization, as the towns were small feudal domains which probably enjoyed a great measure of independence. The Annals wrongly speak of 41 districts. A ling, prefect, administered districts consisting of not less than ten thousand hearths; the smaller districts were administered by a chang, chief.

(167) The paths from north to south and those from east to west were opened up, i.e. for agriculture. The great reform ascribed to Shang Yang was the abolishment of the artificial, the ching system (cf. p. 41), and consequently the paths, running in squares, became superfluous. I take [] in the sense which the T'ung-chien-kang-mu, ch. I, p. 12, gives to it, and which is also followed by Chavannes, op. cit., II, p. 66. The expression is difficult. Escarra and Germain in their La conception de la loi et les théories des légistes à la veille des Ts in (1926), p. 28, take [] in the sense of «instituting ». So does Wieger, Textes Hist., p. 199 [p. 163, éd. 1929], in rendering the phrase by '‘l le remplaca par un réseau de canaux d'irrigation, le long desquels s'alignaient les propriétés ».

(168) The reforms made new taxes necessary. According to the Annals (Chavannes, op. cit., p. 64), these were levied for the first time in 348. For a discussion of these taxes, see p. 46. 
(169) Cf. above, p. 16. This must have been in 346.

(170) This was in 342 ; the five years seem to be counted from the last event onwards. In order to understand this sentence, one should remember that, in the meantime, the prestige of Ch'in's neighbour, Wei, who had threatened for a time to become very strong, had been seriously damaged, and that Chin had, in 349, even sent its troops through Wei's territory for a campaign against Ch'i. The Ch'in Annals say that in 343 the Son of Heaven had conferred on Duke Hsiao the title of leader. The sending of the sacrificial meat, which came from the sacrifices to Wen-wang and Wu-wang, was the solemn confirmation of this dignity. In 342, Duke Hsiao called the feudal lords to a meeting at Feng-chih (in the present Hsiang-fu-sien, in K'ai -feng-fu, in Honan), and was there recognized by them in this position. The Bamboo Annals place this meeting in 345. According to the Annals of the Chou (Chavannes, op. cit., I, p. 304), Ch'in had assembled the princes at the capital of Chou in 344. This meeting at Feng-chi evidently made Wei Yang first known to the other states, for we find in the Annals of Ch'i (Chavannes, op. cit., V, p. 255), in immediate connection with the conferring of the leadership on Duke Hsiao, the notice that the latter, in 342, took Yang, Lord of Shang, into his service.

(171) Han, which had been Wei's ally, broke the alliance after the meeting at Feng-chih, probably realizing that Wei's friendship was of little value. When Wei, thereupon, sent troops to reduce it to allegiance, Ch'i came to Han's rescue and Wei suffered a severe defeat at Ma-ling, identified with a place south-east, of Yuan-ch'eng, in Ta-ming-fu, Chihli, or with a place north-east of Chüan-ch'eng, east of $\mathrm{Pu}$-chou, in Shantung. For these events, cf. Chavannes, op. cit., V, pp. 155 et seq.

(172) i.e. these relations are vital. Cf. the same expression in Han Fei-tzu, ch. 1, par. 2, p. 17.

(173) Cf. note 162 .

(174) Here the policy, which Ch'in followed, is clearly outlined. Wei stretched right across the mountainous region from east to west. If Ch'in could succeed in occupying the Yellow River, which here runs from north to south, and the mountain passes, it would be safe against attacks from the east and would have its points d'appui for invasions of the eastern $\mathrm{S}$ tates. The intelligent anticipation of the later course of events, in this speech, might lead one to suppose that it was written after Ch'in's success. On the other hand, there is nothing impossible in the supposition that a clear-sighted statesman would have consciously guided Ch'in s policy along these lines.

(175) The Annals of Wei (Chavannes, op. cit., V, p. 157) state that Wei was attacked by Ch'in, Chao, and Ch'i toge ther, and mention the ambush laid for Prince Ang. Another version of this incident is given in Lü-shih-ch'un-ch'iu, ch. 22, pp. 4, 5.

« Kung-sun Yang was net a near blood-relation of the prince of Ch'in, nor was he an old friend, but he was employed because of his capacities. Desiring to make himself a success, by some way or other, he found he could do so only by an aggressive policy. Thereupon, he became the general of Ch'in and attacked Wei. Wei dispatched Prince Ang, as general, to meet him. New Kung-sun Yang, when he lived in Wei, had naturally been friendly with the prince, se he sent a messenger to Prince Ang, saying :

- It has been for your sake that I have travelled abroad and have tried to obtain a position of honour. New Ch'in has made me its gen eral and Wei has ordered you to meet me, but how could we bear to fight against each other! Tell your master this and I shall also speak to my lord, and let us both make an armistice.

Hereupon, when they were on the point of withdrawing the armies, he sent another messenger to the prince, saying :

- If we now withdraw, it is not certain when we shall again meet. I should wish to sit once more with you, in order to take leave. 
The prince consented to this, and although the officers of Wei disputed his decision and advised him not to go, he paid no heed, and subsequently sat with Kung-sun Yang. But the latter had set soldiers, chariots, and horsemen in ambush for the purpose, and took the prince prisoner.

The Bamboo Annals, particularly important for the history of Wei, say that in the $9^{\text {th }}$ month of the $27^{\text {th }}$ year of King Hsien (341), Wei Yang of Ch'in attacked "our" (i.e. Wei's) western frontier, and that, in the $10^{\text {th }}$ month, the King engaged in battle with Wei Yang, but "our" army was beaten and fled.

(176) Cf. note 162. This was a complete success for Ch'in. The new capital of Wei, Ta-liang, (the modern K'ai -feng-fu, in Honan), removed the centre of Wei's power far towards the east. The Bamboo Annals place the transfer of capital as early as 365 ; this may have been a temporary removal, which became definite in 340 .

(177) Cf. p. 9.

$(\underline{178})$ The modern Shang-chou in Shensi. The Ch'in Annals add that Yang was appointed lieh-hou, feudal lord. The Ch'u Annals (Chavannes, op. cit., IV, p. 384) say that Yang received Yü (or $\mathrm{Wu}$ ) and Shang in fief. Yü was east of modern Nei-hsiang-hsien, in Nan-yang-fu, Honan, adjoining the territory of Shang. See also below where Yü is mentioned by Chao Liang. The Bamboo Annals, for the same year, say that Ch'in conferred on Wei Yang a fief in $\mathrm{Wu}$, of which the name was altered to Shang. Wu is the territory now comprised by Yen-shih-hsien and Yung-ning-hsien, which is a little to the north-east of the region mentioned above. This slight divergence in detail gives this testimony great independent value.

(179) Not known elsewhere. This interview is a famous piece of literature, often reproduced in anthologies.

(180) An unknown individual.

(181) i.e. "give you a position".

(182) This dictum of Confucius is not otherwise known.

(183) i.e. the great legendary emperor Shun.

(184) i.e. the well-known Po-li Hsi, the councillor of Duke Mu of Ch'in. Cf. Mencius, V, a, 9, and Chavannes, op. cit., II, pp. 26, 27. Duke Mu had in 655 offered a ransum of five ram's skins for him, hence his nickname, $k u$ being a black sheep. The mention of Po-li Hsi's nick name by Shang Yang naturally suggested the comparison in Chao Liang's reply.

(185) i.e. Ch'u.

(186) This is evidently the tradition, contradicted by Mencius, that he sold himself for five ram's skins.

(187) See for the exploits of Po-li Hsi and Duke Mu, the Ch'in Annals (Chavannes, op. cit., II, pp. 25 et seq.). Duke Mu's achievements were the ideal before the eyes of Duke H siao and Shang Yang.

(188) A region in the south-west, which had its centre in the present Chung-ch'ing, in Szech'uan.

(189) For Duke Mu's conquests over the Jung, cf. Chavannes, op. cit., II, pp. 44, 45.

(190) Yu-yü was an envoy of the king of the Jung, whom Duke Mu induced to enter his own service, and assisted by whose advice, he beat the Jung in 623. For details, see Chavannes, $\underline{o p}$. cit., II, pp. 41-44.

(191) i.e. he left well-filled granaries. 
(192) Wieger, op. cit., p. 201 [p.164, éd. 1929], wrongly makes this passage refer to Wei Yang.

(193) Like a prince, thus usurping the power of the ruler.

(194) A title used by ruling princes, as it is characteristic of a ruling prince that he has no father.

(195) Shih-ching, ed. Legge, p. 85.

(196) The tutor whose nose had been sliced off in 346. From the "eight years", we may conclude that this speech was supposed to have been made in 339. Cf. also below : "Five months afterwards, Duke Hsiao died »; that was in 338.

(197) Supposed to have been a colleague of Kung-sun Chia.

(198) A lost ode.

(199) Supposed to be a sign of great strength.

(200) Of the three men on each war-chariot, the one standing most to the right-hand, armed with a lance.

(201) Cf. Han Fei-tzu, ch. 5, par. 18, p. 16, where mention is made of the precautions against attempts on his life, taken by Shang Yang.

(202) Not now to be found in the Shu-ching.

(203) An anachronism.

(204) A euphemism for the death of a prince.

(205) 338 B.C. The new ruler was Hui-wen, (337-311).

(206) Kuan-hsia, perhaps the name of a place.

(207) Cf. the provision against hostelries in par. 2, p. 178.

(208) Cf. Lü-shih-ch'un-ch'iu, ch. 22, p. 5 (following upon the story of Shang Yang's betrayal of Prince Ang) :

«When Duke Hsiao of Ch'in had died and King Hui had come to the throne, because of this affair, he distrusted Kung-sun Yang's actions and desired to punish him. Kung-sun Yang, thereupon, with his private retainers and with his mother, returned to Wei. Hsiang Pi (Comm. states that Hsiang Pi is the same man as Jang Pi, mentioned in the Bamboo Annals as general in the $28^{\text {th }}$ year of King Hui-ch'eng of Liang, 343) would not receive him, saying : After the way in which you, Sir, have turned against Prince Ang, I can no longer, by any manner of means, know you.

In the Wei Annals (Chavannes, op. cit., V, p. 157) the flight to Wei is confirmed.

(209) Min-ch'ih is the present Yung-ning-hsien, in Honan, not far, therefore, from Shang Yang's own fief. Nothing further is known of this battle.

(210) Hui took the title of King in 325 .

(211) The head, arms, and legs were torn off by chariots, which were driven in opposite directions.

(212) In the Chin Annals, all this is recorded under the same year as the death of Duke Hsiao, i.e. in 338 .

(213) i.e. Ssu-ma Ch’ien.

(214) The title of the $7^{\text {th }}$ par. of the present Book.

(215) This does not exist, but the $2^{\text {nd }}$ par. is called [], which has the same meaning. 
(216) Chan-kuo-ts'ê, chap. 7. The story of Shang Yang is, according to the plan of the Chan-kuo-ts'ê, divided up into the part relating to Wei and that relating to Ch'in. The first part is, with minor textual variations, the same as the extract from the Lü-shih-ch'un-ch'iu, given in the note on p. 10 of the Biography. I therefore omit it here. The part of the story here narrated is a continuation of the earlier half. In the Ku-wen-shih-i, as Anthology of ancient literature (1743), the conversation between Chao Liang and Shang Yang is given, in a somewhat shorter form, as an extract from the Chan-kuo-ts'ê. In a comm. to the version of the Lü-shih-ch'un-ch'iu, relating Shang Yang's flight to Wei, a more or less similar account is quoted from the Chan-kuo-ts'ê. Neither of these two references, however, are to be found in my edition of the Chan-kuo-ts'ê.

(217) This should perhaps be eighteen years, which would about cover the period from 356-338. Cf. the Biography in the Shih-chi, p. 12 et seq.

(218) He took the title of king in 325.

(219) i.e. to his fief.

(220) Mém. Hist., V, p. 255.

(221) Ibid., IV, p. 384.

(222) Ibid., V, p. 157.

(223) Cf. above, pp. 22, 23.

(224) Mém. Hist., II, p. 63-8.

(225) Cf. p. 12.

(226) Cf. p. 17.

(227) Cf. pp. 17, 18.

(228) Cf. Chavannes, Mém. Hist., III, p. 27. The text may have suffered in the palace fire of 206, as is suggested by Professor O. Franke (Der Ursprung der Chin. Geschichtschreibung, Sitzungsber. der Preuss. Akademie der Wissensch., 1925, XXIII, p. 299).

(229) La Chine antique, p. 404.

(230) Le roman de Sou Ts'in, Études Asiatiques, II, pp. 127-41.

(231) Cf. p. 146.

(232) Cf. Maspero, op. cit., pp. 108-10. Hirth, Ancient History of China, p. 296, thinks that the ching system is a utopianism, which was never worked in practice, and modern Chinese scholars like Hu Shih (Hu Shih wen-ts'un chap. 2, pp. 247-84) deny its real existence. With Maspero, loc. cit., I believe we have no right to do this. Cf. also Demiéville's summary of $\mathrm{Hu}$ Shih's ideas in B.E.F.E.O., XXIII, pp. 494-9; A. Forke, Das Chinesische Finanz and Steuerwesen, in Mitteilungen des Seminars für Oriental. Sprachen, 1900, pp. 167, 168 ; 0. Franke, Die Rechtsverhältnisse am Grundeigentum in China, 1903, pp. 8-13; and Chen Huan-chang, The Economic Principles of Confucius and His School, 1911, pp. 497-533.

(233) $\underline{\text { III, a, } 3}$; ed. Legge, p. 117.

(234) VII, a, 22 (2); Legge, p. 337.

(235) Ch'ien-han-shu, chap. XXIV, p. 2a.

(236) The Shih-chi calls him Li K'o. He was the author of a now lost code. Cf. P. Pelliot, Notes de bibliographie chinoise (B.E.F.E.O., IX, p. 124), and A. Forke, Geschichte der alten chin. Philosophie, pp. 441-2. Also Chen Huan-chang, op. cit., pp. 569-70.

(237) Cf. p. 72. 
(238) 1 picul equals 10 pecks, or 120 catties. Chavannes (Mém. Hist., II, p. 103) has calculated that a picul, at the time of Ch'in Shih-huang-ti, equalled about 45 modern catties, these being approximately 0,600 kilograms.

(239) Cf. the Book, par. 4, p. 204, where an ounce of gold is said to be equal to 12 piculs of grain.

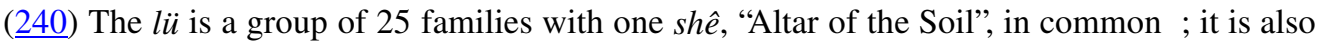
called $l i$.

(241) Cf. pp. 51-3.

(242) Op. cit., note 164 .

(243) It has been suggested to me by an economist, that in view of the general points of similarity between the ching system and the old "open -field system" of the English Manor, the expression [], rendered by "paths and furrows between the fields", corresponds perhaps to the old "balks", which were the thin fringes of unploughed turf separating the strips of arable assigned to different house-holders. Cf. on this system, P. Vinogradoff, The Growth of the Manor, $2^{\text {nd }}$ ed. (1911), p. 175.

(244) Chap. 24, p. 5a.

(245) So far as I am aware, it is, for instance, never mentioned in the Lü-shih-ch'un-ch'iu, which was written in Ch'in and is in many ways typical of that country. There is a reference in chap. 17, par. 1, p. 1, to the tax labour performed in cultivating common land, but there the expression [] is used, and the ching system is passed over in silence.

(246) Chavannes, Mém. Hist., III, pp. 541, 542, defines fu as poll-tax and shui as the levy of $1 / 15$ (in the Han dynasty) on all produce.

(247) Cf. Chavannes, op. cit., II, note 05.336, and Maspero, op. cit., p. 381.

(248) This has been suggested to me by an economist.

(249) Par. 3, p. 188.

(250) Ibid., p. 193.

(251) Cf. par. 6, pp. 220-1. Cf. Han Fei-tzu, chap. 4 par. 13, p. 21 (speaking of Shang Yang's policy) :

« To prohibit people from roaming about in search of office, and to place in evidence farmers and soldiers.

Also par. 14, p. 26 (speaking of the same) :

«To make life difficult for those who were engaged in secondary occupations and to, benefit those who were engaged in the primary occupations.

(252) Par. 2, p. 180.

(253) Idem.

(254) Par. 2, pp. 179, 181, 183.

(255) Cf. p. 15.

(256) Lit. 'Gold kills grain and grain kills gold".

(257) Par. 4, p. 204.

(258) Par. 20, p. 306.

(259) K. C. Wu in his Ancient Chinese Political Theories (Shanghai, 1928), which comes to hand while this work is in the press, is certainly wrong in ascribing to Shang-tzu the idea of a favourable balance, that is, more export than import, which would bring him « entirely in accordance with modern commercial tendencies » (p. 176). 
(260) pp. 94, 95. Cf. the very curious organization of the army in par. 12, p. 250 : there should be one army of able-bodied men, one of able-bodied women and one of the old and weak people ! This is truly a whole nation in arms !

(261) Par. 15, p. 266.

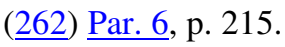

(263) Ibid.

(264) Cf. p. 43.

(265) By this I indicate the unknown author of the Book's older parts.

(266) Cf. Chen Huan-chang, op. cit., pp. 391, 568-70. The text is found in Ch'ien-han-shu, chap. XXIV, p. 4.

(267) tou, which Yen Shih-ku proposes instead of sheng pint.

(268) The comm. explain that in an ordinary year $100 \mathrm{mu}$ yield 150 piculs; a family, needing 200 piculs for living, would have a surplus of 400 piculs per $100 \mathrm{mu}$, when the return is fourfold.

(269) This is not very exact, as, on the same basis of calculation, the family needing 200 a year, the surplus would only be 250 piculs.

(270) Lit. "famine".

(271) Chen Huan-chang understands this as fifty for the government and fifty left to the people.

(272) Chen Huan-chang, op. cit., pp. 506-7.

(273) Forke, Das Chinesische Finanz and Steuerwesen, loc. cit., p. 168.

(274) Cf. his biography in Shih-chi, chap. 101. He was executed in 154. This memorial (Ch'ien-han-shu, chap. XXIV, pp. 6 b et seq.) has been translated by Zottoli, Cursus Literaturae Sinicae, IV, pp. 261-7 ; H. A. Giles, Gems of Chinese Literature, pp. 73-7 ; Wieger, Textes historiques, pp. 421-4 ; and Margouliès, Le Kou-wen chinois, pp. 68-73. With some alterations I follow Giles.

(275) Cf. below, p. 64.

(276) p. 45 .

(277) Demiéville, loc. cit., wrongly translates : «Les champs des riches s'alignèrent par mille et par cents. »

(278) Cf. Ch'ien-han-shu, chap. XXIV, p. 2b. I can only very briefly indicate here this fundamental organization. An excellent exposé will be found in Maspero's admirable book to which I have so often had opportunity to refer, La Chine Antique, pp. 108-19. For a treatment of the significance of the Altar of the Soil Chavannes' masterly study, Le dieu du sol dans la Chine antique, remains unsurpassed (published as an Appendix to Le T'ai-chan. Essai d'une monographie d'un culte chinois).

(279) Chap. 4, p. 14. I leave aside the difference in detail which this passage presents. The work is ascribed to the $2^{\text {nd }}$ cent. B.C.

(280) p. 14.

(281) Chap. 4, par. 13 , p. 21 , and chap. 17 , par. 43 , p. 13 . This last paragraph is admitted to be genuine even by the very critical $\mathrm{Hu}$ Shih.

(282) pp. 295-6.

(283) p. 287. 
(284) p. 291.

(285) p. 321.

(286) See below, p. 148.

(287) p. 179. Cf. also par. 17, p. 279.

(288) p. 212.

(289) Par. 5, p. 213.

(290) Admitted as genuine. In this section a number of brief sententious phrases are first given, and are afterwards explained.

(291) Chap. I, par. 3, p. 15.

(292) We shall discuss these ideas further in Chap. III.

(293) Chap. XXIII, p. 7 b.

(294) Cf. p. 16.

(295) Cf. p. 31.

(296) pp. $14,15$.

(297) Par. 7, p. 231.

(298) Chap. IV, par. 14, p. 26.

(299) Chap. XVII, par. 43, p. 15.

(300) Mém. Hist., II, p. 527.

(301) Chap. XIX, p. 9 b.

(302) Perhaps shu-chang should be rendered by "head or chief of the shu-tzu", for which cf. p. 9 , note 2 . It is curious that the left is here lower than the right.

(303) Cf. p. 15.

(304) p. 296.

(무) pp. 299-300.

(306) Chap. XVII, par. 43, p. 15.

(307) Cf. Chavannes, Mém. Hist., II, p. 103.

(308) Cf. p. 55.

(309) Mém. Hist., III, p. 543.

(310) Cf. e.g. par. 3, p. 185.

(311) Par. 4, p. 205.

(312) Par. 13, p. 253 ; cf. also par. 8, p. 236, and par. 20, p. 304.

(313) Some earlier but rather feeble attempts at classification were made in the survey of philosophers in Hsün-tzu's book "Against the Twelve Philosophers", and in the spurious $33^{\text {rd }}$ book of Chuang-tzu. [Cf. Wieger, Les pères ..., p. 499].

(314) Ch'ien-han-shu, chap. XXX.

(315) Supposed to be the same as Li K'uei, cf. p. 43.

(316) Shen Pu-hai, in 351 appointed minister in Han, died in 337. His works are lost. 
(317) Identified by the comm. Yen Shih-ku, with a man of Chao, mentioned by the Shih-chi; nothing further is known of him.

(318) Shen Tao, to be distinguished from Shen Pu-hai. Supposed to have lived in the fourth century. He was born in the state of Chao, but lived some time in Chi. Cf. Forke, op. cit., p. 442. The statement, there made, that he is mentioned by Shang Yang, is not correct. Fragments, ascribed to him, have been pieced together in the Ming dynasty and now form the book known as Shen-tzu.

(319) Han Fei-tzu, see below.

(320) Further unknown.

(321) Cf. on him p. 54.

(322) Author unknown; Yen was a state in the region where the modern Peking is situated. The book is now lost.

(323) Authors unknown; now lost.

(324) Kuan Chung ; see below.

(325) A small state between the powerful countries Chin and Ch'u, in what is now the province of Honan.

(326) This version, given by the Tso-chuan is preferable to that of Lieh-tzu who says that Têng Hsi-tzu was killed by Tzu Ch'an, because he had criticized the latter's laws. Cf. Forke, op. cit., pp. 418 sqq. [Cf. Wieger, Les pères..., p. 157]

(327) Cf. Forke, loc. cit., and Maspero, pp. 520, 521.

(328) It is beyond the scope of this Introduction to take up the very complicated question of the authenticity of Kuan-tzu. Cf. Maspero, op. cit., pp. 585 sqq., and id., Journal Asiatique, 1927, p. 151. For a somewhat more conservative view see Forke, op. cit., pp. 67 sqq.

(329) Or Hui-ch'eng, 370-319.

(330) Hu Shih, Chung-kuo-chê-hsüeh-shih-ta-kang, p. 227, places him between 480 and 400 B.C., which is too early. Cf. on him and on the explanation of his paradoxes, Forke, op. cit. pp. 427-35.

(331) Cf. Forke, op. cit., pp. 436-41.

(332) Maspero, op. cit., p. 397, also makes Yang Chu, the epicurean, a visitor to this Court, but cf. Forke, op. cit., p. 358, where his life is placed between 450 and 380.

(333) Cf. Forke, op. cit., pp. 503-6.

(334) Cf. Chavannes, Mém. Hist., V, pp. 246-9 ; also ibid., V, pp. 157-8.

(335) Cf. below.

(336) I should also mention Shih-tzu, i.e. Shih Chiao, who is said to have been an adviser and friend of Shang Yang. His ideas, however, have nothing to do with the latter. Cf. on him Forke, op. cit., pp. 520-8.

(337) ?-233.

(338) Chi is supposed to have been the name of one of the gates of the capital of Chi. Cf. Chavannes, op. cit., V, p. 260.

(339) meaning perhaps "the big mouth". Cf. Forke, op. cit., p. 355. [Cf. Chavannes, Mém. Hist., V, n. 46.232]

(340) Hsün-tzu, chap. VI, Dubs, p. 79. 
(341) He is the only one of all those named whose work is said to have come down to us, although not in its original form. Cf. Forke, op. cit., pp. 421-7 ; Maspero, op. cit., pp. 517, 518, and for the translation Masson-Oursel and Tchou Kia-nien (T'oung-pao, vol. XV, 1914, pp. 557-620).

(342) Called Sung K'eng, in Mencius.

(343) Cf. on this academy, Chavannes, Mém. Hist., V, pp. 258-60, and Maspero, op. cit., p. 516. For the dates of King Hsüan, cf. Maspero, "La Chronologie des Rois de Ts'i”" (T'oung -pao, 1927, No. 5).

(344) Cf. my article on "The Chronology of Hsün-tzu" in the T'oung -pao, 1928, No. 2. If we may suppose that Hsün-tzu was practically educated in this sphere, where a man like Yin Wen-tzu, etc., taught, we can understand far better the origin of some parts of his doctrine, such as the $22^{\text {nd }}$ Book, "On the Rectification of Terminology", and his theory of human nature ; also his great controversial skill.

$(\underline{345})$ The $6^{\text {th }}$ Book of Mencius shows unmistakable Taoistic and Terminological influences.

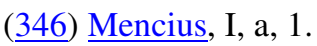

(347) Hou Chi, the ancestor of the Chou House, was conceived by his mother treading on a footprint, made by Shang-ti. Cf. Shih-ching, ed. Legge, II, p. 465.

(348) Cf. Chavannes, Le dieu du Sol dans la Chine antique, pp. 456-7.

(녁) Cheng, to chastise, to make correct.

(350) With the exception of the rulers of the half-barbaric state of Ch'u, who are reported to have claimed the title of King from 704 B.C., the feudal princes did not usurp the title until the fourth century B.C., Ch'i in 378 being the first to do so.

(351) It is absolutely irrelevant whether this is history or romance. The fact that in a story, which was current before 238 B.C. (see supra), this attitude is ascribed to him, which it, is said, finally cost his life, proves that the real difficulties for a statesman were felt to lie in this question.

(352) Cf. p. 149.

(353) Par. 4, p. 196.

(354) Par. 20, p. 303.

(355) Par. 5, p. 207.

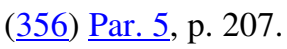

(357) Par. 4, p. 196.

(358) Par. 4, p. 200.

(359) Par. 4, p. 203.

(360) Par. 8 , p. 235 ; cf. also par. 5, p. 211.

(361) All the expressions in the last sentence are denoted by the character [], lit. one-ness, unification.

(362) Par. 5, p. 211.

(363) $\underline{\text { Par. } 5}$, p. 209.

(364) Par. 5, p. 208.

(365) Par. 5, p. 209.

(366) Par. 13, p. 259. 


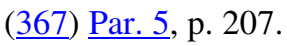

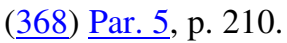

(369) Par. 4, p. 197.

(370) Par. 4, p. 200.

(371) Par. 3, p. 190.

(372) Par. 13, p. 256.

(373) Par. 3, p. 190.

(374) Par. 3, p. 194.

(375) These two are looked upon as one, being complementary to one another. When the country was at peace, men farmed but at need they became soldiers.

(376) Cf. par. 3, p. 186.

(377) Par. 4, p. 201.

(378) Par. 4, p. 199 ; p. 202.

(379) Par. 20, p. 305.

(380) Ibid.

(381) Par. 4, p. 204.

(382) Par. 4, p. 199 ; par. 13, p. 253 ; cf. also par. 2, passim. See for a discussion of these ideas p. 49.

(383) The expression might be rendered "an area of ten miles", but in view of the use of "family" in the parallel phrase I consider the other translation preferable.

(384) Par. 5, p. 213.

(385) Par. 5, p. 212. Cf. further pp. 58 et seq.

(386) This is also the meaning of the last sentence of par. 5, p. 214, « Therefore in a country that has the true way, order does not depend on the prince, and the people do not merely follow the officials ». Forke, op. cit., p. 456, misunderstands this phrase as : «In einem wohlgeordneten Staatswesen hört man bei der Regierung nicht auf dem Fürsten, and das Volk folgt den Beamten nicht. » Professor Forke explains this as meaning that the prince should take popular feeling into account.

(387) Par. 13, p. 254.

(388) Par. 5, p. 211.

(389) Cf. below, p. 114.

(390) Ch. Chü̈-li, ed. Couvreur, p.53.

(391) Li-chi, loc. cit.

(392) Par. 2, p. 176.

(393) Forke, op. cit., p. 94.

(394) Cf. Hu Shih, Chung-kuo-chê-hsüeh-shih-ta-kang, pp. 370, 371.

(395) Cf. below, p. 119.

(396) See above, p. 68.

(397) See above, p. 46. 
(398) See above, p. 89.

(399) I know that Mencius is often called "democratic" because he said ( VII, b, 14) that "the people are the most important in a state"; but to call this democracy is merely one of the many unhistorical interpretations, to which Chinese phrases lend themselves so easily and which are so much the fashion.

(400) Mencius, II, a, 5 .

(401) There are some variations. In par. 18 the idea of rewarding the virtuous is completely rejected, as this would be "like giving rewards for not stealing". But par. 22, which evidently comes from another school of thought, pleads for liberality in the bestowal of rewards.

(402) See also Chap. IV, where the value of the different paragraphs is discussed.

(403) Cf. pp. 71 et seq.

(404) Chap. 17, par. 43, pp. 12 sqq.

(405) Ed. Masson-Oursel, loc. cit., p. 569.

(406) Ibid., p. 585.

(407) Cf. pp. 218, 219, 225.

(408) Par. 5, p. 207.

(409) Par. 5, p. 211.

(410) p. 205.

(411) Cf. also par. 15, p. 266.

(412) Par. 24, p. 318.

(413) Kuan-tzu, chap. VI, par. 16, p. 113.

(414) Chap. 17, par. 40, pp. 1 sqq.

(415) p. 319.

(416) Par. 18, p. 293.

(417) Par. 26, p. 333.

(418) Par. 18, p. 288.

(419) Par. 18, p. 291.

(420) Masson-Oursel, loc. cit., p. 568.

(421) Lit. the weight on a steel-yard, that which makes the scale turn, the over-weigh, the deciding influence, authority. As a verb, it means "to weigh out things against each other," "to act according to circumstances". Masson-Oursel here renders it by: "combinaisons d'équilibre". Cf. below, my translation of the Book, note 799.

(422) I do not think Masson-Oursel's translation of [] by "le recours à un objet tranchant" is correct.

(423) Ibid., pp. 569 sqq.

(423a) The Ming-chia.

(424) pp. 331 sqq.

(425) p. 327.

(426) p. 333 .

(427) Cf. pp. 226, 260, 262. 
(427a) Par. 14, p. 262.

(428) p. 314.

(429) Chap. XI, par. 31, p. 216.

(430) This is, of course, in contradiction with the older part of the Book; cf. p. 85.

(431) p. 2.

(432) [] meaning, idea, sense of what is right. Cf. note 435.

(433) Chap. III, par. 11 ; Forke, Mê Ti, pp. 214 et seq.

(434) Hsün-tzu, XIX ; cf. Dubs, p. 213.

(435) [], below, for the sake of convenience, rendered by the more general expression "moral sense". It denotes primarily the feeling for dis tinctions between father and son, superior and inferior. Dubs, op. cit., p. 48, misunderstands, I believe, Hsün-tzu's argument. Hsün -tzu does not regard man's sociality as the essential element in human nature, as Dr. Dubs thinks, but the moral quality of $i$, which makes society possible and thus gives man power over nature.

(436) Ibid. IX ; cf. Dubs, p. 136.

(437) cf. ibid., XVIII, Dubs, p. 193 sqq.

(438) The Book, par. 14, p. 262.

(439) Han Fei-tzu, chap. 17, par. 40, p. 6.

(440) Loc. cit., p. 7.

(441) This had been argued by an opponent.

(442) A once famous coachman in Chin.

(443) In autumn the hair of animals is supposed to be very long and fine.

(444) I is the famous archer. Granet, Danses et légendes de la Chine antique [css : lire 'ancienne'; chercher 'Yi l'archer'], splits him up into two personalities, one the good, the other the bad archer, but it is not convincing. P'eng Meng is said to have been a pupil of I, and to have killed him because I surpassed him in the art. Cf. Mencius, IV, b, 24.

(445) Han Fei-tzu, chap. 17, par. 41, p. 9.

(446) Kuan-tzu, chap. 6, par. 16, p. 115.

(447) Masson-Oursel, p. 592.

(448) Cf. above, p. 74. I see no reason to attach Sung Hsing, as Maspero does, op. cit., p. 516, to the School of Law.

(449) Lit. "transg ressing the order". . Masson-Oursel has "quittant le rang".

(450) These ideas are connected with those of the ch. Hung fan, in the Shu-ching (Legge, II, pp. 320-44) [Cf. Chou king, trad. Couvreur, pp. 194-209]. Cf. Hackmann, Chin. Philosophie, München, 1927, pp. 37-40.

(451) Lun-yü, II, 1 [Cf. Louen yu, trad. Couvreur].

(452) Cf. for example, Mencius, VI, b, 4 (6).

(453) Mencius, VI, b, 2 (1).

(454) Cf. Mencius, I, a, 7 (20).

(455) Hsün-tzu, chap. VIII, par. 12, p. 1.

(456) jen. 
(457) The Book of Lord Shang, par. 18, p. 294.

(458) Ibid., par. 9 , p. 243.

(459) The Book of Lord Shang, par. 18, p. 290.

(460) Ibid., par. 13, p. 253.

(461) Ibid., par. 24, p. 322.

(462) Ibid., par. 26, p. 334.

(463) Han Fei-tzu, chap. 19, par. 50, p. 26.

(464) Ibid. Cf. also the Book, par. 18, pp. 290-1.

(465) The Book of Lord Shang, par. 7, pp. 229-30.

(466) Chap. 19, par. 49, p. 8.

(467) Chap. 18, par. 46, p. 5.

(468) Cf. p. 89.

(469) Cf. Lun-yü, XIII, 18 [Cf. Louen yu, trad. Couvreur]:

The Duke of Shê informed Confucius, saying :

- In our district there are those who may be styled upright in their conduct ; If their fathers have stolen a sheep, they will bear witness to the fact.

Confucius said :

- Among us, in our part of the country, those who are upright are different from this. The father conceals the misconduct of the son, and the son conceals the misconduct of the father. Uprightness is to be found in this.

The influence of the controversies of the followers of Confucius with the School of Law is clearly discernible in this anecdote.

(470) Han Fei-tzu, chap. 19, par. 49, p. 10.

(471) p. 284.

(472) Par. 6, p. 221.

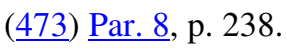

(474) p. 2.

(475) The men of Sung often play the part of Irishmen in Chinese anecdotes.

(476) This must have been in the present province of Chê-kiang.

(477) Mo Ti, chap. 25. Cf. Forke, Mê Ti, pp. 310, 311.

(478) [], "acquired by nurture".

(479) Cf. the Book, par. 3, p. 187.

(480) Kuan-tzu, chap. 15, par. 46, p. 306.

(481) Ibid, chap. 21, par. 67, p. 416.

(482) Ibid., chap. 6, par. 16, p. 117.

(483) Par. 18, p. 292.

(484) Par. 23, p. 317. Cf. also the warnings against flatterers in the same paragraph.

(485) Dubs, Hsüntze, p. 261. The argument is directed against Shen Tao.

(486) The Book, par. 18, p. 287. 
(487) Cf. p. 58.

(488) Par. 24, p. 319.

(489) Par. 23, p. 316.

(490) Par. 24, p. 321.

(491) Ibid. p. 319.

(492) Ibid. p. 320.

(493) Ibid. p. 322.

(494) p. 333.

(495) Ibid.

(496) pp. 327-9.

(497) p. 329.

(498) p. 328.

(499) p. 330.

(500) p. 335.

(501) Cf. also O. Franke, Der Ursprung der Chinesischen Geschichtschreibung (Sitzungsberichte der Preuss. Akad. d. Wissensch., 1925, XXIII, p. 305).

(502) Hsün-tzu, XVI, pp. 14, 15. For scholars the character $j u$ is used, meaning Confucian scholars.

(503) Ibid., XXIII, p. 11 ; Dubs, pp. 311, 312.

(504) Chap. 4, par. 13, p. 21. This is not mentioned among the genuine books by Hu Shih.

(505) Chap. 19, par. 49, p. 14. The chapter is admitted as genuine.

(506) i. e. pars. 11 and 49 of the present Han Fei-tzu edition.

(507) Shih-chi, chap. 63.

(508) Cf. his biography in Shih-chi, chap. 53, p. 1a, also in Ch'ien-han-shu, chap. 39, p. 1a.

(509) Cf. pp. 43, 51-53.

(510) It is said, that the rough Emperor was so much impressed by it, that, when the ceremonies were over, he exclaimed : - Now I know what it means to be an emperor !

(511) Cf. Mém. Hist., III, p. 558, and chap. 123.

(512) Cf. Wieger, La Chine, p. 87.

(513) Pelliot, Notes de bibliographie chinoise, B.E.F.E.O., IX, pp. 124, 125.

(514) Hsün-tzu, IX, p. 4. My translation differs from Dr. Dubs, who renders the phrase by (op. cit., p. 123): "For if he goes by law but does not look into things, then those cases to which the law is not applicable will certainly be done wrong."

(515) Chap. 13, par. 30, p. 16.

(516) Chap. 17, par. 43, p. 15.

(517) Chap. 19, par. 49, p. 13.

(518) Wang Shih-jun (see infra) believes it to have been the same book.

(519) The reference is to Liu Pei, "The First Ruler", who died in 223 and confided his son the 'Later Ruler" (223 -265) to Chu-ko Liang's care. 
(520) The "Six Chapters on Strategy" is supposed to be as old military treatise. Cf. Wylie, n., p. 89.

(521) Cf. P. Pelliot, Notes de bibliographie chinoise, in Bulletin de l'école française d'extrême orient, II, p. 315. This book was lost in China from the Sung dynasty and came back from Japan at the end of the eighteenth century.

(522) 1108-1166, cf. Giles, Biogr. Dict., No. 265.

(523) Cf. Wylie, Notes on Chinese Literature (1902), p. 29.

(524) In calling his edition a printed one I follow the Lü-t’ing-chih-chien-ch'uan-pen-shu-mu of Mo Yu-chih (end of nineteenth century).

(525) $1241-1253$.

(526) See infra.

(527) A chin-shih of the Chia-ching period (1522-1566).

(527a) A chin-shih of 1586.

(528) He lived in the T'ien-chii period (1621-1628). See on him Wylie, Notes, pp. 26 and 187. He published the Chu-tzu-ch'i-shang.

(529) See infra.

(530) I do not know its date, but suppose that it is also a Ming edition.

(531) He took his degree in 1540 .

(532) The Lü-t'ing-chih-chien-ch'uan-pen-shu-mu also mentions an edition by the Mien-miao-ko, which presumably is also a Ming edition.

(533) A chin-shih of the Chia-ching (1522-1566) period, who collected a large and famous library, called the T'ien-i-ko. The library remained intact long after his death through the care of his descendants, who took special measures that it should not be opened except in their presence. Later it suffered heavy losses; a catalogue made by one Ch'ien Hsün in the Kuang-hsü (1875-1908) period, shows that, since the days of Chia-ch'ing (1796-1821), when Juan Yüan did the same, a tenth of the books had disappeared. I do not know when this T'ien -i-ko edition was first printed.

(534) A scholar and philologist of the Ming dynasty, who became kung-sheng, senior licentiate, in the Wan-li period (1573-1620).

(535) Cf. however the edition mentioned on p. 135.

(536) Besides the copies mentioned, Yen also quotes a copy corrected by Yeh; Wang Shih-jun, in his Preface, p. 1b, from whom I take this information, does not know who is meant.

(537) A chin-shih of the Ch'ien-lung period (1736-1796), and in his turn a disciple of the famous Tai Chen (1724-79). Cf. Kuo-hsüeh-chi-k'an, vol. II, No. 1, p. 130. Giles in his Biogr. Dict. No. 1848, gives the date 1722-77, but this is incorrect.

(3ㅛ) See above, p. 135.

(539) A chin-shih of the Ch'ien -lung period (1736-96), who died in 1818, held a position in the Board of Punishments, wrote on various classical books, such as Mo-tzu, and Yen-tzu-ch'un-ch'iu; was interested in codes of law — an excellent scholar. His edition was published in 1803 by the Wen-ching-yang. Cf. for his activity in connection with the codes of law, Pelliot, Notes de Bibliographie chinoise, B.E.F.E.O., IX, pp. 124-5.

(540) I have not found the date of this work.

(541) A chin-shih of the T'ung -chih period (1862-75). 
(542) A chin-shih of the Chia-ch'ing period (1796-1821).

(543) The Lü-t'ing -chih-chien-ch'uan-pen-shu-mu also mentions an edition by one Chu Weijan, which probably is a Ch'ing edition.

(544) At Shanghai.

(545) In an appendix to the book are published 'Shen -tzu" in one chapter, and "The Sayings of the Agricultural School" in four chapters.

(546) Cf. p. 136.

(547) He held office in Hupei.

(548) i.e. Wang Hsiang-ch'i. For his writings see the Tang-tai-pa-chia-wen-ch'ao "Eight contemporary authors"(1916).

(549) Two more fairly recent editions might be mentioned : a reprint of Yen Wan-li's ed. was published by the Chung-hua Book Co, (no date) and in 1925, the Ch’in-tung-tu-shu-chü, also published a new ed.

(550) Viz. the paragraphs 2, 3, and 4.

(551) Reference to par. 3, p. 187.

(552) Cf. p. 134.

(553) Chung-kuo-chê-hsüeh-shih-ta-kang, (1919), p. 383.

(554) Hsien-ch’in-cheng-chih-ssu-hsiang-shih (1923), p. 112. Tai Tê and his cousin Tai Sheng $\left(2^{\text {nd }}\right.$ and $1^{\text {st }}$ century B.C.) each made a collection of writings on the $l i$, preparatory to the definite compilation of the present $L i$-chi. The two cousins are usually distinguished as Ta Tai and Hsiao Tai, "the elder and younger Tai".

(555) Materialy po kitajskoj, filosofii, vvedenie škola fa (1912), p. XV.

(556) Geschichte der alten Chinesischen Philosophie (1927), p. 454.

(557) 6, 9, and 14 are mentioned (the notes 4 and 5, loc. cit., should be interchanged).

(558) 4, 19, and 20.

(559) La Chine antique (1927), pp. 520-1.

(560) Ancient Chinese Political Theories (1928), p. 338.

(561) Chap. 6

(562) Cf. Chavannes, Mém. Hist., V, pp. 71 et seq.

(563) p. 330.

(564) p. 328.

(565) Cf. Chap. III, p. 122.

(566) Cf . Chap. II, p. 63.

(567) Op. cit., p. 454.

(568) p. 145.

(569) Cf. ibid.

(570) Cf. p.131.

(571) Cf. for a discussion of these ideas, pp. 82 et seq.

(572) p. 187. 
(고) Cf. p. 133.

(574) Göteborgs Högskolas Årsskrift, XXXII, 1926, 3.

(575) For the sake of simplicity I only give the pages and the paragraphs in which they occur.

(576) Cf. note 4 on p. 296, and note 4 on p. 299.

(577) pp. 59, 60 .

(578) $O p$. cit., p. 62. For an examination of Chuang-tzu's style cf. also G. von d. Gabelentz, Die Sprache des Cuang-tsï (Abhandlungen der Philol. -Histor. Classe der Kön. Sachs. Ges. d. Wissenschaften, 1888).

(579) Chung-kuo-chê-hsüeh-shih-ta-kang, p. 365.

(580) Sitzungaberichte der Königlich Preussischen Akademie der Wissenschaften Jahrgang, 1892 , p. 145.

(581) Cf. Maspero, Journal Asiatique, 1927, p. 151, in a review of G. Haloun, Seit wann kannten die Chinesen die Tocharen oder Indogermanen überhaupt ? (Leipzig, 1926, Asia Major.)

(582) Cf. above, pp. 144-5.

(583) Cf. p. 133.

(584) Cf. par. 7, p. 228, and par. 8, p. 238.

\section{TRANSLATION of the BOOK of LORD SHANG}

(585) Cf. with this chapter, the discussion in Ssu-ma Ch’ien's biography of Shang Yang (p. 12 of the present book), the version of the Hsin-hsu, ch. 9, pp. 25 et seq., and the discussion on the advisability of adopting the clothes of the $H u$ barbarians, between King Wu-ling of Chao (325-299), Fei I, and others, in ch. 6 of the Chan-kuo-ts'ê, which resembles this chapter in general scope and gives most of it in similar or identical phrases, although very disjointedly. The latter discussion, held in 307 B.C, is, with certain modifications, reproduced in the Shih-chi (cf. Chavannes, Mém. Hist., V, pp. 71 et seq.).

(586) The Hsin-hsü has a different introduction:

«Duke Hsiao of Ch'in desired te employ the advice of Wei Yang, to alter laws and punishments and to make them severe and cruel and to reform the institutions of the three dynasties. But he was afraid that the Ministers of State would not agree, so thereupon he called the Great Officers, Wei Yang, Kan Lung, and Tu Chih to be in attendance on him.

(587) Here the version in the Shih-chi begins :

«Yang desired to alter the laws, but he (the Duke) feared that the empire would find fault with him.

The rest is identical, unless otherwise stated.

(588) Chan-kuo-ts'ê, lot. cit., has a similar phrase :

«Let the King at once settle his thoughts about turning the back on transmitted customs and perhaps not heed the criticism of the empire.

(589) The Chan-kuo-ts'ê, loc. cit., p. 16, has a similar passage :

« Those, who have the merit of a high position in the world, turn their backs on the complications of handed-down customs, and those who have thoughts of independent knowledge are feared by the mass of men.

(590) Omitted by Shih-chi. 
(591) The same phrase occurs in Chan-kuo-ts'ê, loc. cit., p. 17.

(592) Omitted by Shih-chi. Kuo-Yen is mentioned in Han Fei-tzu, ch. 5, par. 18, p. 16, as a man, who reformed Chin, and thereby made the success of Duke Wen possible. He is supposed to be the same as Kao Yen, mentioned by Mo-tzu, ch. 1, par. 3, p. 6. Cf. also Lü-shih-ch'un-ch'iu, ch, 2, p. 11.

(593) The same phrase occurs in Chan-kuo-ts'ê, loc. cit., p. 17.

(594) Cf. Kuan-tzu, ch. 6, par. 16, p. 110:

«Law is the father and mother of the people.

(595) The whole sentence is missing in Shih-chi. The last half is found in Chan-kuo-ts'ê, loc. cit., p. 18.

(596) Chan-kuo-ts'ê, ch. 6, p. 21, has a similar speech :

«I have heard it said : "A sage teaches without changing the people, and a wise man acts without altering the laws". If one teaches in accordance with the spirit of the people, success will be achieved without effort, and if one acts holding on to popular custom, one's plans will be promptly realized and one will easily see results.

(597) Not in Shih-chi.

(598) Shih-chi omits the whole phrase as well as the following.

(599) With some variations, this whole speech is found in Chan-kuo-ts'ê, ch. 6, p. 20 :

(The King said) :

- What you hold, my Minister, is a point of view found with men in the street. Ordinary people are immersed in what is the popular practice, and students are absorbed by what is reported. These two kinds of people are all right for being made officials and for obeying the government, but not for seeing far ahead, nor for discussing origine. Moreover, the Three Dynasties attained kingship by different clothes, and the five Lords Protector governed by different teachings. A wise man creates the teachings, but a foolish one is controlled by them. A man of talent discusses popular custom, but a worthless man is enslaved by it. Now, with people, who are controlled by fashion, it is not worth while to speak about the mind, and with the crowd, who are enslaved by popular custom, it is not worth while to express one's thoughts.

(600) Omitted by Shih-chi.

(601) Shih-chi omits this entire passage, from the beginning of Kung-sun Yang's speech on.

(602) The Chan-kuo-ts'ê, ch. 6, p. 21, has a very similar passage :

- Moreover, in following antiquity, one makes no mistakes and in cultivating established rites, one commits no offence. I wish that Your Majesty would aim at that !

The King said :

- Ancient and modern times have not had the same customs, so what antiquity should one take as an example? The emperors and kings have not imitated one another, so what rites should one follow? Fu Hai and Shen-nung taught but did not punish ; Huang-ti, Yao, and Shun punished, but were not angry, and later the Three Kings regulated the law, with a view to what was opportune, and regulated rites, according to practical requirements. So laws and standards, regulations and orders were all expedient, and clothes and implements were all practical. Therefore, there is more than one way to govern the world, and there is no necessity to imitate antiquity in order to take the appropriate measures for the state. As regards the success of the sages - they attained supremacy, without 
imitating one another ; and as regards the decline of the Hsia and Yin dynasties, they perished, without the rites being altered. Consequently, acting counter to antiquity does not deserve blame, nor does following established rites deserve to be made much of.

(603) Shih-chi ends the discussion at this point.

(604) Hsin-hsü has :

«Thereupon Duke Hsiao rejected the excellent counsel of Lung and Chih and followed the wrong advice of Wei Yang.

(605) The repetition of this phrase is suggested by Wang.

(606) "outside standards", i.e. different from those mentioned here, which attach value only to merit, acquired by agriculture or war.

(607) Wang Shih-jun suggests that the sentence "criminals", etc., should be repeated.

(608) Here again Wang Shih-jun suggests repeating "hotel-keepers having no means of subsistence".

(609) Cf. par. 17, p. 279, and Introduction, p. 59.

(610) Cf. Chou-li, ch. 8, p. 4b : 'On important occasions, service was extended to the younger sons". A gloss says that they guarded the pal aces.

(611) It would be more natural to translate : « and orders should be given to them (i.e. to the women) to trade », but this does not give a satisfactory sense. My translation is a guess : the texte may be corrupt.

Yin reads [] «Women should be allowed to serve as soldiers, but they should be ordered to trade », which gives perhaps the best sense. Cf. however par. 12, p. 250, where it is said that women should be organized into a special corps.

(611a) I follow an unnamed commentary quoted by Wang, who explains that such things would delay the grain traffic.

(611b) "one -ness", i. e. to be engaged in one thing only, viz. agriculture and war, which are considered complementary to each other.

(612) Cf. par. 2, p. 176 [note 606] ; par. 3, p. 188 ; and par. 14, p. 264, note 5.

$(\underline{613})$ I follow Wang's excellent emendation. He compares it with Ho Kuan -tzu, ch. 6, pp 18b, 19a:

«Princes, without the right way, employ insignificant individuals, so that, in every act, there is confusion ; princes, with the right way, employ men of genius, so that, in every act, there is clearness.

(614) Yü suggests omitting this last clause, as it does not occur further down, where the est is repeated.

(615) Cf. Par. 14, p. 264.

(616) Cf. for this expression, par. 22, p. 312.

(617) Cf. for the style of this passage Han Fei-tzu, ch. 4, par. 14, pp. 23 and 25.

(618) Cf. par. 2, p. 176 [note 606] ; par. 3, p. 186 ['improper standards'] ; and par. 14, p. 264, note 5 .

(619) Cf. p. 186.

(620) Cf. the dictum on p. 191.

(621) Cf. par. 4, p. 198 ; par. 5, p. 212. 
(622) The text is defective and some words like these should be supplied.

(623) Cf. par. 4, pp. 199, 200 ; par. 5, p. 206 ; par. 13, p. 256 ; and par. 17, p. 282.

(624) Cf. for the entire passage par. 4, p. 200 ; par. 13, p. 256-7 ; and for the last phrase par. 5 , p. 208. For the various groups of "evils" cf. Introduc tion, p. 85.

$(\underline{625})$ [] is a small green caterpillar, which eats the heart of the plants, whereas the [] eats the leaves. Cf. Shih-ching, ed. Legge, p. 380.

(626) Cf. the dictum on p. 189.

(627) Wang suspects an omission after this.

(628) Cf. Lü-shih-ch'un-ch'iu, ch. 26, p. 6 :

«If people farm, their estates yield returns; this being so, they will look upon changing their residence as an important thing, and in consequence will die in their homes and will not have two thoughts.

A few lines further, "many opportunities of deceit" is called the result of 'love of knowledge".

(629) Cf. $\underline{\text { Li-chi }}$, ch. Ch'ü-li, ed. Couvreur, I, p. 84 : « un simple officier doit mourir, s’il le faut, pour le maintien des lois et des ordonnances ». Cf. par. 8, p. 234.

(630) Cf. Lü-shih-ch'un-ch'iu, ch. 26, p. 6 :

«If the people reject what is primary and pursue secondary things, they are not virtuous; not being virtuous, they cannot be used for defence or aggressive warfare ; and if the people reject what is primary and pursue secondary things, the yields of their land will be sketchy, and this being the case, they will think nothing of moving their residence.

(631) Cf. par. 4, p. 202.

(632) Lit., «bands of five men », squads.

(633) Cf. par. 25, p. 324 .

(634) I translate according to the sense of par. 20. The meaning seems to be that a state, that in successful warfare allows its people to become strong, inevitably becomes weak itself; whereas, if the people remain weak even in a successful war, then the state will be able to retain its strength, as, in Lord Shang's opinion, a strong state necessitates a weak people.

(635) That is if it employs virtuous officials.

(636) Cf. par. 20, p. 305 .

(637) Cf. par. 20, p. 305 .

(638) Cf. Par. 5, p. 210, and Lü-shih-ch'un-ch'iu, ch. 26, par. 3, p. 7b, where the expression refers to farmers, artisans and merchants.

(639) Cf. par. 20, pp. 306-7, which is more explicit.

(640) Lit. « six lice ».

(641) Yin suggests reading [] 'weeds', but human vices, not natural difficulties, are enumerated here. Cf. the explanation in par. 20, p. 307.

(642) Cf. par. 3, p. 190 ; par. 4, p. 199 ; par. 5, p. 210 ; par. 13, p. 256 ; par. 20, p. 306.

(643) The raw material [] are the persons, to whom the lice affix themselves; i.e. through whom these functions operate. 
(644) The meaning seems to be that a big country may be over-governed, and so loses its power, whereas for a small country, a strict administration may lead to greatness. Cf. par. 20, p. 307.

(645) I insert the words "people" and "army" according to the sense of the context in par. 20, p. 308.

(646) Cf. par. 3, p. 190 ; par. 4, p. 200 ; par. 5, p. 206 ; par. 13, p. 256 ; and also par. 17, p. 282.

(647) Cf. par. 5, p. 207, in more detail.

(648) Here eight things are mentioned instead of ten; perhaps the last two have been forgotten in copying and the character "ten" later altered into eight. Cf. par. 4, p. 199 ; par. 5, p. 206 ; par. 13, p. 256 ; and also par. 17, p. 282.

(649) Cf. par. 3, p. 190 ; par. 5, p. 208 ; and par. 13, p. 257.

(650) Cf. par. 5, p. 208 ; and par. 13, p. 257, where similar passages occur. In some ed. Eighteen characters follow, which in par. 13 also follow on hese words, but which seem to be out of place here. Yen rightly omits them.

(651) Cf. Han Fei-tzu, ch. 2, par. 8, p. 17 :

" The method of a sage is to banish knowledge and cleverness; unless these are banished, it will be difficult to establish constancy.

(652) Cf. par. 5, p. 210.

(653) Cf. par. 5, p. 210. Fines, etc., impoverish the rich.

(654) Cf. ibid.

(655) Cf. par. 5, p. 211 ; par. 7, p. 230.

(656) Cf. par. 3, pp. 193-4.

(657) Thus I render the force of shai "to diminish, to wither". Wang obse rves that the idea is as above on p. 36, viz., that a country, which is prosperous, should start a war, so as not to be harmed by the evil bye-products of civilization, such as rites and music, etc.

(658) i.e. which carries on a suicidal policy.

(659) Cf. the same passage in par. 5, p. 212, and also, for the meaning, par. 8, p. 236.

(660) The text uses three times the character [], which cannot, very well, be rendered by the same word in each instance.

(661) This should be five. For the explanation of the whole passage cf. par. 5, p. 213, and par. 13 , p. 252.

(662) Cf. ibid. and par. 2, p. 175.

(663) Cf. par. 19, p. 295.

(664) Cf. par. 5, p. 209 ; par. 7, p. 231, with note 2 ; and par. 13, p. 259. Also, for the same idea, par. 17, pp. 278 et seq.

(665) Cf. par. 5, p. 210 ; par. 7, p. 232 ; and par. 13, p. 259.

(666) Cf. par. 13, p. 254. The phrase does not belong here.

(667) i.e. in a grain-producing country grain expels money, and the export of grain is not allowed. Cf. with this passage, the remark on export and import in par. 20, p. 306.

(668) [], "figures" by Shang -tzu, often used in the sense of "statistics". Cf. par. 6, p. 216. 
(669) [], those, who are worth their salt.

(670) [], rats, the personnification of slyness and wickedness.

(671) Cf. par. 3, p. 190 ; par. 4, p. 199, 200 ; par. 13, p. 256 ; and also par. 17, p. 282.

(672) Cf. par. 7, p. 232 ; and par. 13, p. 256.

(673) Cf. Han Fei-tzu, ch. 20, par. 54, p. 13 :

«If the people loves the law, wickedness will have no chance to sprout.

(674) Cf. par. 4, p. 200.

(675) Cf. par. 3, p. 190 ; par. 4, p. 200 ; par. 13, p. 257. Here the contexte explains the meaning.

(676) Cf. par. 4, p. 201 ; par. 13, p. 257.

(677) Wang suggests reading in the first half of the sentence, « if laws are concise ».

(678) Cf. par. 26, p. 333-4.

(679) Cf. par. 4, p. 203 ; Cf. par. 7, p. 231, with n. 2 ; par. 13, p. 259 ; also for the same idea par. 17, pp. 278 sqq.

(680) Cf. par. 4, p. 201.

(681) Lit. « lice», cf. par. 4, p. 197, etc.

(682) I have here again reversed the order of the words «rewards » and «punishments ». Cf. par. 4, p. 201.

(683) Cf. ibid.

(684) i. e farming, trading and office. Cf. par. 4, p. 197.

(685) Cf. par. 4, p. 204 ; Cf. par. 7, p. 232 ; Cf. par. 13, p. 259.

(686) i.e. the six parasitic functions as enumerated in par. 4, p. 197.

(687) Probably shame, disgrace, labour and hardship, mentioned in par. 6, p. 223.

(688) Cf. par. 4, p. 202, and par. 7, p. 230.

(689) Cf. par. 4, p. 202, and for the meaning of the whole passage, cf. par. 8, p. 236.

(690) Cf. par. 3, p. 109, and par. 4, p. 198.

(691) Cf. par. 14, p. 261.

(692) lit. 'instrument”. Cf. par. 20, p. 307, and K uan-tzu, ch. 5, par. 15, p. 105 :

«The former princes had three means for governing a country; commands and orders, axes and halberds, emoluments and rewards.

(693) i.e. the people themselves, by denouncing all crimes, are the chief enforcers of the law.

(694) Cf. par. 2, p. 175 ; par. 4, p. 203 ; par. 13, p. 252, and Introduction, p. 87.

(695) There seems to be a gap in the text.

(696) The text seems to be defective : in par. 15, p. 286, a parallel text runs : "cities, towns and highways with one tenth, barren fields with one tenth, fertile fields with four tenths". Wang suggests reading "poor fields with two tenths", in this way accounting for the ful 1 number of tenths.

(697) Yen suspects an omission. Wang suggests omitting "marshes and moors" in the last part. 
(698) [] here seems to be 'to lead troops, to take the offensive". Perhaps it should be rea d 'to seize, to attack".

(699) Cf. Han Fei-tzu, ch. 20, par. 56, p. 17

« Indeed, those who are most intelligent in governing by law, rely on statistical methods and do not rely on men. Consequently a country, which has method, does not use men of reputation, and thus makes no errors. It is because reliance is placed on statistics that, within the territory, order reigns ; and it is because reliance is placed on men and not on statistics, that in a ruined country, soldiers are allowed to over-run the territory without anyone being able to restrain them. Reliance on men is a suicidal policy, but by reliance on statistics one may attack others.

(700) For the meaning of "power", cf. par. 24, p. 318 et seq.

(701) This should perhaps be omitted.

(702) i.e. they carry their merchandise on their backs.

(703) Not like farmers, who are tied to the soil.

(704) Cf. Han Fei-tzu, ch. 5, par. 15, p. 6, where there is a similar expression :

«The regular householders are poor and those who borrow a dwelling are rich.

(705) Cf. par. 7, p. 227.

(706) The sense seems to be : "in order to keep the world from doing forbidden things".

(707) Like small merchants or pedlars.

(708) i.e. agriculture.

(709) Cf. par. 5, p. 211, where four kinds of hardships are mentioned.

(710) The text is not very clear, but the meaning seems to be that there should be system in the punishments.

(711) This phrase offers some difficulty; note that it rejects criminals as officials, whereas elsewhere, e.g. par. 5, p. 207, it is said that the wicked should govern the virtuous.

(712) The same expression occurs in Han Fei-tzu, ch. 20, par. 54, p. 13.

(713) Cf. par. 8, pp. 235-6.

(714) i.e. he assigned to each their property, rights and duties.

(715) Cf. par. 6, p. 221.

(716) Cf. par. 8, p. 238.

(717) Cf. Han Fei-tzu, ch. 2, par. 7, p. 2 :

«What the people hate are capital and bodily punishments.

(718) Wang suggests reading : "That which I call righteousness".

(719) Yen suggests inserting: "and in a disorderly country, rewards are numerous and punishments rare".

(720) Cf. par. 4, p. 202 ; par. 5, p. 211 ; and Han Fei-tzu, ch. 20, par. 54, p.13 :

«If punishments prevail, the people are quiet, but if rewards abound, villainies spring up. Therefore, in governing a people, the prevalence of punishments is the first principle for order, but abundance of rewards is the basis of disorder.

(721) [] used as a verb - "to achieve virtuous actions". 
(722) Cf. par. 4, p. 203 ; par. 5, p. 209 ; par. 13, p. 259, and for the same idea, par. 17, pp. 274 et seq. Cf. also Han Fei-tzu, ch. 9, par. 30, p. 16 :

«Kung-sun Yang's law says : 'Punish severely light crimes. People do not easily commit serious crimes, but light offences are easily abandoned by people. To cause people to abandon what they regard as easy and not to stay away from what they think difficult, is the way of good government. (This phrase does not seem to belong to the context.) Now, if small offences do not arise, big crimes will not come and thus people will commit no crimes and disorder will not arise. One (this is a commentary, quoting the phrase from par. 13, p. 87) says: «Kung-sun Yang said that in applying penalties, the light offences should be regarded as heavy, for if light offences do not appear, heavy ones will not come. This means the abolishment of punishments by means of punishments. »

Cf. also Kuan-tzu, ch. 1, par. 3, p. 15 :

«If one desires the people to be correct, it is necessary to prohibit small offences, for big offences originate from small ones. If small offences are not prohibited, it is impossible to obtain that big offences shall not harm the state.

(723) Cf. par. 4, p. 204 ; par. 5, p. 259 ; par. 13, p. 210.

(724) i.e. by practising "the eight things". Cf. par. 5, p. 206.

(725) Cf. par. 13, p. 253.

(726) $)$ i.e. agriculture and war.

(727) cf par. 3, p. 193.

(728) Cf. Han Fei-tzu, ch. 4, par. 13, p. 21 (speaking of Shang Yang's laws). Cf. Introduction, p. 83 , and par 23 , p. 317.

(729) i.e. trade, etc.

(730) [] ; this refers to "the way to public benefit" and "the gate of private intrigue".

(731) i.e. to let the energy of the people develop.

(732) Lit. 'lice', cf. par. 4, p. 197.

(733) Cf. par. 4, p. 202 ; par. 5, p. 212.

(734) [] is used in both cases. Their riches and their dissoluteness should be "abolished".

(735) - for which they have had to pay. Cf. par. 13, p. 253 ; par. 20, p. 304.

(736) Cf. Han Fei-tzu, ch. 20, p. 14 :

« Therefore, when a sage governs the people, his laws change with the times.

(737) i.e. that the more rewards are promised, the more will people commit crimes, and the lighter the punishments are, the less people will strive for rewards.

(738) Cf. par. 11, p. 247.

(739) Lit. "a soldier's substance".

(740) Cf. par. 20, p. 308, and Han Fei-tzu, ch. 14, par. 35, p. 20 :

«King Chao-hsiang said : "The law of our Ch'in state is that people who have merit are rewarded and those who commit crimes are punished.

(741) lit. 'substance'.

(742) Cf. Kuan-tzu, ch. 8, par. 20, p. 153 :

«(The sage) assigned their habitat to workmen according to the official residences, and to the merchants according to the market places.

(743) Cf. Mencius, II, a, 2 (22) : 
«... not to serve a prince who was not his own, not to make use of people who were not his own (said of Po I).

(744) Cf. Han Fei-tzu, ch. 20, par. 56, p. 15 :

« The people like profit and emoluments and dislike punishments and penalties; the ruler makes use of their likes and dislikes in order to direct the people's energy.

(745) Cf. more fully, Kuan-tzu, ch. 21, par. 67, p. 426 :

" The method of the intelligent ruler is, on the one hand, to establish what the people desire in order to acquire their services, therefore he institutes titles and emoluments so as to encourage them; on the other hand, to establish what the people hate, in order to prohibit their wickedness; therefore he institutes punishments and penalties, so as to deter them.

(746) Cf. par 20, p. 309.

(747) I render [] by bravery here. The meaning is that people should only exert themselves for the public benefit.

(748) This phrase seems out of place here ; it sounds very Confucian.

$(\underline{749})=$ Li Lou. Cf. Mencius, IV, a, 1.

(750) Cf. Lun-yü, I, 7 :

«If a man values wisdom instead of beauty », where [] is also taken in the sense of "to transfer, to exchange".

(751) Cf. Mencius, VI, b, 3.

(752) A chün is thirty catties.

(753) Cf. par. 20, p. 309, where practically the same passage occurs.

(754) Cf. Han Fei-tzu, ch. 2, par. 9, p. 29 :

« The crime of bravery in fights between various cities should not be pardoned.

(755) Cf. Tso-chuan, $7^{\text {th }}$ year of Duke Wen (Legge, p. 247) [Tso tchouan, trad. Couvreur, t. I, p. 486] :

«Hostilities within the state are rebellion, while hostilities outside the borders are directed against enemies.

(756) I do not find this in Sun Tzu's Art of War, but the meaning resembles his dictum : Do not press a desperate foe too hard. (ch. 8).

(757) Cf. Sun-tzu, ch. IV, 17 (Giles, p. 31) :

«In respect of military method, we have : (1) measurement, (2) estimation of quantity, (3) calculation, (4) balancing of chances, (5) victory.

(758) Cf. Sun-tzu, ch. XI, 20 (Giles, p. 123) :

« The principles to be observed by an invading force, and passim.

(759) Cf. Sun-tzu, ch. III, 18 (Giles, p. 24) :

«Hence the saying: "If you know the enemy and know yourself, you need not fear the result of a hundred battles. If you know yourself but not the enemy, for every victory gained, you will also suffer a defeat. If you know neither the enemy nor yourself, you will run risks in every battle.

(760) And not to individual merit.

(761) Wang Shih-jun suggests : «If the enemy is strong and your own army weak ». This, however, does not fit the contexte. Perhaps 'equal' should be added.

(762) i.e. before the battle. Cf. Sun-tzu, ch. I, 26 (Giles, p. 7) : 
«Indeed, if a general, after having made his calculations in the temple before the battle, is victorious, it is because a great many of his calculations have come true. But, if, after having made his calculations in the temple before the battle, he is not victorious, it is because only a few of his calculations have come true. Thus do many calculations lead to victory and few calculations to defeat. How much more no calculations at all ! Looking at it from this point of view, one can see who will gain victory or suffer defeat.

My translation differs somewhat from that of Giles.

(763) The text seems corrupt and I translate according to Yen's emendation. But perhaps the first part without emendation may be rendered :

« It is a mistake when there are no enemy troops (in front), to penetrate deeply »,

the meaning being that by the absence of resistance one should not allow oneself to be tempted too far inland.

(764) Cf. par. 9, p. 238.

(765) This phrase is a mere repetition and sounds like a commentary that has crept into the text.

(766) Wang rejects the reading [] "to contain" which the Ch'ung -wen ed. has and which I prefer.

(767) This also reads like a commentary.

(768) There is a repeated play here on the words [] and [], which I have rendered by the words "worn out" and "fresh". The meaning is clear enough.

(769) The phrase 'It is regarded", etc., is no doubt a commentary. The expression 'these three things" remains obscure. By the last phrase one is reminded of the precept in Sun-tzu, ch. III, 3, 4 (Giles, pp. 17-18) :

« The worst policy of all is to besiege walled cities; the rule is not to besiege walled cities if it can possibly be, avoided.

(770) Cf. Mo Ti, ch. 15, par. 70, p. 313 (Forke, p. 626) :

«Up to a hundred paces outside the outer wall cut away and remove completely all walls and trees, large and small ... Pull down the houses on the space outside, and cut all the trees, and carry everything which might be used for the attack on the city inside the city ... Burn the wood, which ca nnot all be transported into the city, and do not let the enemy make use of it.

For the part played by women in warfare, cf. Mo Ti, loc. cit., p. 302, and ch. 14, par. 52, p. 279 (Forke, pp. 620 and 606).

(771) This section is, for a great part, identical with Han Fei-tzu, ch. 20, par. 53, pp. 10-13.

(772) chin is used of a martingale, used to keep a horse's head down.

(773) The comm. all seem to have misunderstood this passage : Wang Hsien-shen takes [] as mile and thinks that the time for covering this distance is meant, but he is certainly wrong. Cf. par. 2 , p. 175 ; par. 4 , p. 203 ; par. 5, p. 213 , and Introduction, p. 59.

(774) Cf. par. 7, p. 233.

(775) i.e. trade, etc.

(776) Cf. par. 8, p. 236 ; par. 20, p. 304. The text in Han Fei-tzu is not so good.

(777) Cf. par. 4, p. 199. Wang Shih-jun remarks that it might be better to alter 'poor' into 'rich', which would bring it into accord with the text in par. 4, and which gives better sense. For "the six kinds of parasites", cf. par. 4, p. 197 ; par. 20, p. 306. Han Fei-tzu omits this passage. 
(778) Cf. par. 4, p. 204. Han Fei-tzu reads "awe-inspiring courage". I do not understand Ivanov's translation ... i.e. 'by virtue of mag nificence to create wise plans and courage in war". Ivanov here and elsewhere also mistranslates [] as "vrag" — "enemy".

(779) Han Fei-tzu has []. Cf. par. 4, p. 198. The meaning is, that the law works smoothly and automatically, and special measures are unnecessary.

(780) Han Fei-tzu has : 'to grant rank according to merit". The following passage is omitted by him. Cf. p. 256, note 5 .

(781) If the officials have been selected on a wrong principle, the law does not work smoothly, and constant interference with law measures is necessary.

(782) i.e. of good government. Yen suspects the text of being corrupt.

(783) Cf. par. 4, p. 197 ; par. 20, p. 305, for a different use of the same expression.

(784) Cf. par. 3, p. 190 ; par. 4, pp. 199, 200 ; par. 5, p. 206 ; par. 17, p. 282. The numbers given are different in each case ; here there are really sixteen things.

(785) Cf. par. 5, p. 206 and par. 7, p. 232.

(786) Cf. par. 4, p. 197 and par. 20, p. 306.

(787) Here the text is resumed by Han Fei-tzu. Cf. p. 254, note 5.

(788) Cf. par. 3, p. 190, and par. 4, p. 200.

(789) [] should be taken in the sense of activities in war and agriculture, i.e. merit. Cf. par. 14, p. 260.

(790) Cf. par. 3, p. 190 ; par. 4, p. 200 ; par. 5, p. 208.

(791) Before this sentence Han Fei-tzu inserts a passage of 57 characters which, in a corrupt form, have been taken from ch. 8, par. 27, p. 26, of the same book, and do not belong here.

(792) Cf. par. 4, p. 197, and par. 20, p. 305. Also Kuan-tzu, ch. 22, par. 73 :

«If the profits escape through one opening, the state will have no equal; if it escapes through two openings, its army will not subdue others; if it escapes through three openings, it will not be able to mobilize an army ; if it escapes through four openings, the state is doomed."

Han Fei-tzu reads the second and third clauses :

«If the profit escapes through . . . outlets, the army will be only half used ; if the profit escapes through ten outlets, the people will be preserved.

But the text is not so good.

(793) Cf. par. 4, pp. 200-1 and par. 5, p. 208, for similar passages.

(794) The text adds [], 'punish lightly the heavy offences", but these words are omitted by Han Fei-tzu, and are not found in the corresponding passages in par. 4, p. 203, and par. 5, p. 209. With Wang I prefer to omit them.

(795) The second half of this phrase is omitted by Han Fei-tzu. Cf. par. 4, p. 203, and par. 18, p. 285.

(796) Cf. par. 4, p, 203 ; par. 5, p. 209 ; and par. 7, p. 231, with note 2. The rest of the paragraph is not in Han Fei-tzu.

(797) Cf. par. 3, p. 190 ; par. 17, p. 283, note 2.

(798) Cf. par. 4, p. 204 ; par. 5, p. 210 ; and par. 7, p. 232.

(799) [] ; it is difficult to give a satisfactory rendering of this character. Lit. it means the weight of a steel-yard, as in par. 6, p. 218, hence the deciding influence and authority, as in par. 6, p. 225. It is here used for the right standard in judging things. 
(이) [] ; cf. par. 2, p. 176.

(01) This phrase has been misunderstood by Mai Meng-hug, op. cit., p. 20, who explains [a] as the ruler's supreme authority, exercised by him a lone ; likewise Ivanov, op. cit., p. LXI : "verkhovnaja vlast-prerogativa pravitela", i.e. "the supreme power is the prerogative of the ruler". The use of [] 'to establish, to fix", and the context below make it perfectly clear, that [a] has the sense which I have given to it.

(02) [] [] cf. par. 7, p. 265, and par. 26, pp. 332 et seq. For the literal sense of the expression see also below, p. 262.

(0ㅗ) Cf. par. 5, p. 212.

(04) Cf. Kuan-tzu, ch. 17, par. 53, p. 343 : 'rewards and punishments are civil and military measures".

(05) Ch'ung -wen ed. : "pays heed to the law".

(06) Here and in the following there is a play on the different meanings of [] "model, standard, and law".

(07) Cf. Han Fei-tzu, ch. 15, par. 36, p. 6 :

«Those who fulfill the standard are rewarded: those who do not fulfill the standard are punished.

(08) Cf. Han Fei-tzu, ch. 2, par. 9, p. 30.

(809) Cf. Kuan-tzu, ch.. 17, par. 52, p. 338 :

«Indeed, if the ruler likes what is fundamental, then upright scholars will come to the front, but if the ruler likes profit, then scholars, full of blame for some and of praise for others, will be at his side. If the ruler often enjoys cleverness (perhaps "in speaking" [] should be inserted) and rewards do not follow upon their respective merits, then soldiers will not place themselves at his disposal.

(10) This is a reference to the fact that Yao and Shun did not give the empire to their sons.

(11) i.e. laws and regulations.

(1812) Lit. "sell the standards", i.e. be ing willing, for money, to give office on other grounds than those of merit. These are the [] "deviating or improper standards", mentioned in par. 2, p. 176 ; par. 3, pp. 186,188 . Cf. also par. 3, p. 187, where the expression has been simply rendered by "sell power".

(13) Cf. Han Fei-tzu, ch. 5, par. 15, p. 7 :

«The snapping of wood is due to wood-worms having eaten through; the collapse of a wall is due to fissures having split through.

( 1414$)$ Cf. the title of the $49^{\text {th }}$ par. (ch. 19) of Han Fei-tzu : "The five wood-worms".

( $\underline{815})$ One-tenth is lacking; Wang suggests that the barren fields should have two-tenths. Cf. par. 6, p. 215.

(16) $1,000 l i$ is the standard of a big country.

( $\underline{817})$ The three states, Han, Wei, and Chao, into which the state of Chin had been divided in 376 B.C.

(818) Comm. suspect the text of being corrupt, but their emendations are unconvincing, and it would seem that it can be very well explained as I have done it. The idea of the last part of the phrase is that Han and Wei made a mistake in encouraging not agriculture but trade.

$(\underline{819})$ i.e. for soldiering.

(20) [] ; i.e. trade.

(821) a title which the rulers of Ch'in adopted in 325 B.C., i.e. after the death of Shang Yang. 
(822) Cf. par. 10, p. 244, for other quotations.

(823) 334-319 B.C., but the same person reigned from 370-335 as Duke Hui-ch'eng ; cf. Chavannes, Mém. Hist., V, p. 159 and pp. 462, 463. Again, the events mentioned occurred long after the death of Shang Yang, and the "four generations" (on p. 270, three generations), which are mentioned, enable us to date this paragraph as being approximately of the middle of the third century B.C. Cf. also note 831, and the Introduction, p. 145.

(24) i.e. agriculture.

(25) Cf. above, p. 268, "4 generations".

(826) Cf. for the whole passage the [], Chi-chung-chou-shu (cf. Chavannes, Mém. Hist., I,

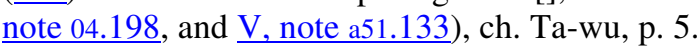

(827) The methods of the "Great Warfare" (Ta-wu) are a reference to this chapter. Presumably by the "Extensive Culture" (Kuang -wen) another, but lost, chapter of the same book is meant. Yin, who suggests the alterations in the two previous notes, also wishes to alter [a] of the text into "to freeze", as in the Chou -shu. I should prefer to do the opposite, as I do not see how one can cause the vegetables of the enemy to freeze ! [a] is used of old wine, old grain, etc.

(828) These will all emigrate to Ch'in .

(829) In 771 B.C., when Duke Hsiang of Chin assisted the Chou dynasty against the Jung barbarians and escorted King Ping to his new capital in Lo, as a reward, he became an independent feudal lord, and so laid the foundation of Chiin. Cf. Chavannes, Mém. Hist., II, pp. $14,15$.

(830) In 697 B.C., Duke Wu fought the P'eng -hsi tribe who cut Ch'in off from the Chou, and made his way to the Hua Mountain. Cf. Chavannes, Mém. Hist., II, p. 20. This mountain lies a little to the south of the sub-prefecture of Hua-yin, in the prefecture of T'ung-chou in the present Shensi. Cf. ibid., I, note 02.192 .

(831) In 260 B.C., Ch'in completely routed the army of Chao at Ch'ang -ping, cf. Chavannes, Mém. Hist., II, p. 91. The reference to this battle here is of particular interest, as it shows that this part of the text, at any rate, is about a century later than Shang Yang himself. Cf. note 823 , and par. 20 , p. 310 . The words here may be a later addition, as a few lines earlier only two, and not three, battles are mentioned.

(832) Because the retainer had left him.

(833) "A bird in the hand is worth two in the bush".

(834) Should be four.

(835) The idea is that the kings of antiquity only made the country strong during their own reigns, but by this suggested far-sighted policy, the results would chiefly appear later.

(836) See below for an explanation of these sententious phrases.

(837) Tsan-mao is said to have been to the south of the present prefecture of Shang-chiu in Honan province.

(838) The town of Chou, at the foot of the Chi mountains (the prefecture Feng-hsiang, in Shansi province) was the home of the later Chou dynasty.

(839) Ming-t'iao was the name of a steep hill in the sub-prefecture of An-i, in Shensi province. Cf. Chavannes, Mém. Hist., I, p. 170.

(840) $m u$, south of the sub-prefecture of Chi, prefecture of Wei-hui, in Honan province. Cf. ibid., pp. 207 and 228-35.

(841) The expression "nin e armies" is used of the Imperial Army. 
(842) Cf. Chavannes, Mém. Hist., V, note 47.418, and Henri Maspero, La Chine Antique, pp. 134, 135. King Chao of Ch'u wanted to present Confucius with 700 hamlets with their "god of the soil", and the peasants attached to it, and of Kuan-tzu it is said that he had received 300 "registered gods of the soil" which made him the richest man i n Ch'i. This, however, did not constitute a fief, but the land with its tenants was given rather in usufruct. In the primitive organization of twenty-five families, each $l i$ had its own "god of the soil". Cf. the Introduction, p. 57.

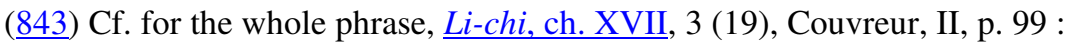

«Les chevaux (qui avaient traîné les chars de guerre) furent mis en liberté au midi du mont Hua, pour n'être plus jamais attelés (à ces chars). Les boeufs (qui avaient traîné les voitures de bagage) furent mis en liberté dans la plaine auprès de la Forêt des pêchers pour n'être plus jamais attelés (à ces voitures).

Cf. also Chavannes, Mém. Hist., I, p. 243, where the same phrase occurs.

(844) The last emperor of the Hai dynasty.

(845) The last emperor of the Yin dynasty.

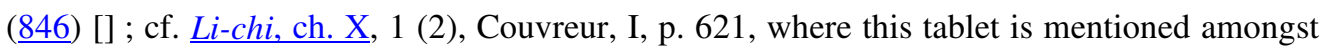
the appurtenances, carried about his person, by an accomplished young gentleman.

(847) Cf. for utterances regarding punishments, e.g. par. 4, p. 203 ; par. 5, p. 209 ; par. 7, p. 231 ; par. 13, p. 259 ; par. 18, p. 288.

(848) The tradition of Shang Yang's life shows, that in this point, he acted according to his own reported teaching, and even expected the crown prince to obey the law. See p. 16.

(849) [][] ; it is not always clear what is meant by this expression. In the Shih-chi it denotes : parents, brothers, wife and children ; in the Han-shu : father, son and grandson ; in the I-li : father's brothers, one's own brothers, and one's sons' brothers (Tz'u -yuan). I take it here in the sense of the Chou-li.

(50) Cf. par. 2, p. 179.

(51) 636-628 B.C.

(852) According to the laws of the Chou dynasty, Chou-li, ch. 18, p. 24b: "At military inspections, a late arrival was punished with death."

(853) [] seems to stand for [] 'to stab" (see Tz'u -yüan), which according to Yin is the method used for putting to death high officers.

(854) The expression [] "to veer the fields towards the east" means that the farmers were ordered to plough their fields from east to west instead of from north to south, so that an army, coming from Chin, could easily follow the furrows and paths between the fields.

(855) Cf. also Han Fei-tzu, ch. 13, par. 34, pp. 27, 28, where the story of the punishment of Tien Hsieh is told with some detail and in connection with it the campaigns of Duke Wen are described with certain variations from our text. The order of events as here narrated is incorrect. From Chavannes, Mém. Hist., IV, p. 299, it appears that the Duke of Chin, wanting to attack Ts'ao (632), asked permission from Wei to cross its territory. When this was refused he crossed the Yellow River at its southern passage, invaded Ts'ao, then attacked Wei, and in the first month took Wu-lu, now called Wu-lu-ch'eng, in Ta-ming-fu in Chih-li. Ch'eng-p'u is a place in Honan, of which the exact position is unknown : in 632 Duke Wen gained there a big victory over Ch'u. Cf. Chavannes, Mém. Hist., II, p. 36 et al. Ching is Ch'u. The attack on Cheng by Duke Wen is two years later than the affair at Ch'eng-p'u, in 630. Cf. Chavannes, [Mém. Hist..] IV, p. 307.

(56) i.e. they could stop so suddenly. 
(857) For this affair, cf. Chavannes, Mém. Hist. I, p. 245. The Duke of Chou, the famous brother of King $\mathrm{Wu}$, had taken the regency at the latter's death (1116) and put an end to a conspiracy of his own brothers.

$(\underline{858)}$ [][] is a new edition of the list of vices. For the others, cf. par. 3, p. 190 ; par. 4, pp. 199, 200 ; par. 5, p. 206 ; par. 13, p. 256.

(599) Cf. Mencius, II, b, 10 : 'to catch in one's net the whole gain of the market".

$(\underline{860})$ Cf. par. 3, p. 190 and par. 13, p. 259 : Here an antithesis is made between « universal knowledge » and « selecting what is important ».

(861) i.e. the mythical emperor Fu Hsi, usually called T'ai Hao.

(62) Because the animals were so scarce. Cf. for the expression, Li-chi, ch. IV, 1 (19), Couvreur, I, p. 337.

(63) Because of the lack of wood.

(864) The foregoing are examples of the policy of Fu Hsi and Huang-ti.

(65) Cf. par. 4, p. 203 ; par. 13, p. 259.

(66) Cf. Kuan-tzu, ch. 17, par. 53, p. 345, where the same simile is used of the law.

(67) Who were mutually responsible. Cf. par. 19, p. 296 ; and Introduction, p. 58.

(6ㅇ) Cf. par. 12, p. 250.

(869) Liang Chï-ch'ao, op. cit. (Escarra and Germain, p. 58), in quoting this phrase refers it to Kuan-tzu, par. Ch'i-fa.

(70) Cf. Han Fei-tzu, ch. 9, par. 30, p. 17 :

«Now there is no heavier punishment than to be cut to pieces and exposed on the market-place, and if, in spite of this (crimes) do not cease, it is because criminals are not always caught.

(1871) Cf. for this idea, par. 1, pp. 278 et seq., and the references in note 847.

(872) A notorious robber of the time of Confucius, who was said to have been the younger brother of the virtuous Liu-hsia Hui ; cf. Mencius, III, b, 10 (3), ed. Legge, p. 161. [Cf. trad. Couvreur, p. 457]

$(\underline{873}) 12^{\text {th }}$ century BC. A man of lofty character ; cf. Mencius II, a, 2 (22) et al.

(74) Cf. par. 24, p. 319.

(875) The meaning, which is explained in what follows, is that the ruler does not withhold the customary rewards and distinctions for public services, but that he should not use his servants for illegal and selfish purposes and reward them specially for actions of that nature. Cf. Han Fei-tzu, ch. 18 :

«Titles for merit should only have their origin in the official law; all that is outside the law, however difficult the action may have been, does not entitle to distinctions.

(76) lit. "me" ; a figure of speech, indicating the ruler.

(877) i.e. in private quarrels. Cf. Kuan-tzu, ch. 17, par. 53, p. 345 :

«Therefore, if in a state there are many who are braves in private quarrels, the army will be weak.

(78) The meaning becomes clear by comparison with Han Fei-tzu, ch. 19, par. 50, p. 26 :

«In strictly managed households, fierce rebels will not appear, but a compassionate mother has spoilt sons; from this I know that by severity violence 
may be prohibited, but that virtue and kindness are not effective in causing disorder to cease.

(7ㅇ) Cf. par. 24, p. 321.

(8ㅇ) Cf. Han Fei-tzu, ch. 15, par. 36, p. 28 :

«When the men devote themselves completely to farming, and the women exert themselves in weaving, receipts are many.

This paragraph on riches does not seem to belong here.

(881) Here, as below, in the repetition of the expression "what is called strength", a brief definition is given in other words, repeating the sense of what has just been said. The two definitions are complementary to one another.

(82) Cf. Lao-tzu's dictum, par. 33 : 'He who conquers himself is strong”.

(883) The same phrase occurs in Han-shih-wai-chuan, ch. 2, p. $6 \mathrm{~b}$; in a conversation between Duke Ai of Lu (494-467 B.C.) and his minister T'ien Jao, where the yellow crane is opposed to the cock; the latter, in spite of its excellent qualities, is eaten, whereas the former is honoured, merely because it comes from afar.

(884) The Ch'i-lin is the well-known fabulous deer, and the Lü-êrh is one of the eight excellent horses of Chou Mu-wang (1001-946). The Tz'u-yüan quotes the expression in Huainan-tzu.

(85) Cf. the same simile in Kuan-tzu, ch. 17, p. 345, where it is clearer :

«Therefore, if they clearly understand where advantage and harm lie, the way the people avoid the one and make for the other, is like the behaviour of fire with regard to dry or wet things, or of water with regard to high and low.

(86) $)$ [] is used, meaning both "method" and "law".

(887) Cf. Mencius, VI, a, 10, Legge, pp. 287-8 [Cf. trad. Couvreur, p. 571-2]:

«I like life indeed, but there is that which I like more than life and therefore I will not seek to possess it by any improper means ... There are cases when men by a certain course might preserve life, and they do not employ it . . . Here are a small basket of rice and a platter of soup, and the case is one in which the getting them will preserve life, and the want of them will be death : - if they are offered with an insulting voice, even a tramper will not receive them, or if you first tread upon them even a beggar will not stoop to take them.

(8ㅛ) When law prevails there is nothing remarkable about this.

(889) The expression may denote the sons of secondary wives or the younger sons of the principal wife, but also it may refer to the eldest son of a prince or high dignitary of the prince's family. Hence as a title, it is also used for the officer is charge of the instruction of the latter. These instructors used to guard the palace during the absence of the prince on expeditions. (Cf. Li-chi, VI, 2 ; Couvreur, I, p. 482.) Here the $s h u$ - $t z u$ are said to serve, and to go on expeditions with the great officer, so I have ventured to render the expression by 'bodyguard".

(900) Cf. note 899 .

(91) The meaning is that those four men were killed because they were unable to save the fifth.

(892) Cf. Introduction, p. 63, and Han Fei-tzu, ch. 17, par. 43, p. 15 :

«The law of the Lord of Shang said: «Those who take one head receive one degree in rank, and those who desire an office (instead), receive an office of 50 piculs of grain; those who take two heads, receive two degrees in rank, and those who desire an office (instead), receive an office of 100 piculs of grain. 
(93) Short weapons, such as swords, as distinguished from bows, used at long distance.

(94) [] ling administrates a hsien. Cf. Introduction, p. 18.

(895) During the Ch'in dynasty there were four wei in the capital, of which the chung-wei was the head of police.

(966) Under the Ch’in dynasty, in each district there were two military com manders.

(897) For all these ranks instituted by Shang Yang, cf. Introduction, p. 62.

(98) One ch'ing is $100 \mathrm{mu}$.

(899) Cf. the analogous phrase at the beginning of this paragraph, note 890. Cf. also Chien-han-shu, ch. 23, p. 4b (speaking of Shang Yang's system) :

«Merit and reward corresponded to one another; if the heads of five armed men were captured, one received five families into one's service.

(900) [][] is by the Tz'u-yuan defined as an office, the head of the scavengers and dusters of the palace ; here it rather denotes a slave-servant.

(901) Cf. Li-chi, XIX, 3 (31), Couvreur, II, p. 249, where prescriptions are given about the different thicknesses of the coffins for people of different rank.

(902) Cf. de Groot, "The Religious system of China”, Bk I, pp. 421 and 461 et seq.

(903) It is not easy to understand this process exactly. Cf. Mo-tzu, ch. 14, par. 62, p. 287 (Forks, Mê Ti, p. 611) :

«The ancients, who were clever in attacking, burrowed the earth and entered thus ; they fastened a beam and made fire, and thus they destroyed the city-wall.

Some sort of mine seems to be meant.

(904) By the nature of their work the sappers have not the same chance as other soldiers to capture heads, although they may fight bravely.

(905) The idea of this uncertain paragraph seems to be that the responsibility of the corps of sappers is especially great. If they show bravery, although they capture no heads, yet by special favour they receive the same rewards as those who do capture heads ; but on the other hand, in case of cowardice, they are held mutually responsible and ten men are punished for one man's fault.

(906) Cf. note 895 .

(907) The tsu are the officers from the second degree up to the fourth degree; cf. p. 113. Perhaps are meant some kind of officers, who supervise the troops and report on their conduct.

(908) That is, the first are rewarded, the second are reprimanded ; cf. p. 301. Both treatments seem to be indicated by the character [], which, however, cannot be rendered by the same word in the translation.

(909) This is difficult. I cannot give any other sense to [][]. It has indeed been said on p. 301 that only 18 men are used on each side of the town, a very small number. As their work offers a special chance of promotion (cf. note 3, p. 302), in case of necessity men are called as volunteers for this corps. Perhaps [] should be read [] as Yin suggests, which would then make the sentence mean :

«the utmost use is made of their mechanical devices, and if these are not sufficient, their desire for rank must do the rest.

(910) The meaning seems to be that whereas, on the one hand, licence weakens the people, on the other hand, it gives them also the chance of developing the six "parasites".

(911) Cf. par. 4, p. 196, and also p. 308 below. 
(912) The meaning seems to be that they should be encouraged to impoverish themselves by buying titles. Cf. par. 8, p. 236 ; par. 13, p. 253, and also Introduction, p. 65.

(913) Cf. par. 4, p. 198, for the reference to "twofold strength" ; also p. 308.

(914) Cf. par. 4, p. 197 ; par. 13, p. 258, with the quotations given in note 792.

(915) This seems to be the meaning of the phrase here. But cf. also par. 13, p. 255, for a different use of the same phrase.

(916) Cf. the remarks about the relation between gold and grain in par. 4, p. 204.

(917) Cf. par. 4, p. 197.

(918) Cf. the same passage in par. 4, p. 197.

(919) I take [] in the sense of "chercher un lieu de repos ou de refuge". Cf. Couvreur, s.v.

(920) Cf. par. 5, p. 213.

(921) The text does not seem to be quite in order, as the phrases do not entirely correspond.

(922) Cf. par. 4, p. 198.

(923) The rest of the paragraph from here on is in a different style from the earlier part.

(924) Cf. par. 9, p. 240.

(925) Cf. par. 9, p. 242.

(926) Cf. this passage, which is slightly different, with that in par. 9, p. 243, where it fits in much better with the context.

(927) With variations this same passage occurs in Hsün-tzu, ch. 10, (Dubs, The Works of Hsüntze pp. 216-17) from where it has been taken over into the $23^{\text {rd }} \mathrm{ch}$. of the Shih-chi (Chavannes, Mém. Hist., III, pp. 216-18) ; it is also found in Han-shih-wai-chuan, p. 13b, and, with greater variation in Huai-nan-tzu, ch. 15, p. $7 \mathrm{~b}$.

(928) A place in the present Ho-nan, prefecture of Nan-yang, formerly in the state of Ch'u ; it produced iron.

(929) [] "scaly dragon" (Gi les), but Hsün-tzu has "shark".

(930) Rivers in Ho-nan which after joining become a tributary of the Huai.

(931) South of the present prefecture of Hsiang-yang in Hu-pei.

(932) The Fang Mountains were in the N.E. of Hu-pei; there was a wall of some $10 \mathrm{li}$.

(933) In 279 B.C. the King of Chin took Yen, and in 278, Ying. Yen was south of the sub-prefecture I-ch'eng, in the prefecture of Hsiang-yang in Hu-pei ; Ying was the capital of Ch'u, situated $10 \mathrm{li}$ north of Chiang-ling, in the prefecture of Ching-chou in Hu-pei.

(934) The general of Ch'u.

(935) Hsün-tzu, loc. cit., reads Ch'ui -sha ; its locality is unknown. The battle occurred in 301 B.C. In the Annals of Ch'in, Ssu-ma Ch'ien reports this battle in 299 B.C. Cf. Chavannes, Mém. Hist., II, note 05.400, and III, note 23.150.

(936) Chuang Ch'iao had been ordered by King Wei of Ch'u (339 -329 B.C.) to pacify the central part of Yün-nan and had there created a principality for himself. Cf. Chavannes, Mém. Hist., I [, Introduction], p. LXXIX.

(937) Hsün-tzu gives three or four parts ; Shih-chi has four parts. Cf. Chavannes Mém. Hist., III, note 23.152, where the four partitions are enumerated. Chavannes dates the fourth partition in 241. It is not clear what is meant by the fifth. The mention of these various historical events is particularly important, as they show that this part of the text, at any rate, is later than 301, 278 , and even 241. 
(938) This sentence is not in the parallel text ; in Hsün-tzu the end runs :

« How could it be said not to have any firm ramparts, narrow passes or mountain defiles ? But the reason was that it did not organize the people by the right principle.

(939) This is a fragment which does not seem to belong here. Cf. par. 14, p. 262.

(940) Cf. par. 3, p. 187.

(941) But elsewhere it is said that rewards should be few. Cf. par. 7, p. 68, et al.

(942) Cf. par. 2, p. 177.

(보) Or "subjects".

(944) Cf. though slightly different, Han Fei-tzu, ch. 17, par. 46, p. 28 :

« Names and appellations were fixed, in order to indicate honour ... rank and position were set up, in order to be the basis of humble or noble degree...

(945) Also "models and standards ".

(946) Lit. measures of length and quantity.

(947) Cf. Han Fei-tzu, ch. 5, par. 19, p. 24 :

« To relax the rules and rely on ability, to relax the law and rely on knowledge, is the road to confusion and disorder.

(948) Cf. Mencius, VI, a, 2 (2) :

" The tendency of man's nature to moral virtue is like the tendency of water to flow downwards.

(949) lit. 'to hol d one's wrist", i.e. preparatory to battle.

(950) Cf. par. 8, p. 235.

(951) shih ; cf. the definition in Han Fei-tzu, ch. 18, par. 48, p. 21 :

« Power is the quality, by which one is stronger than the masses.

It is the power which relies on the general condition of things as distinct from "force" sometimes it is best rendered by "circumstances" or "conditions". Cf. Introduction, p. 97 et seq.

(952) [] ; elsewhere (e.g. par. 6, p. 218) this has been rendered by "statistics". In this par. it stands for figures, to calculate figures, mathematical law, system.

(953) Exigeron Kamschatikum : its woolly seeds fly about like hair (Giles).

(954) Cf. par. 9, p. 243.

(955) Cf. note 952.

(956) [] ; the ch'eng were assistants to the prefects ; by the chien may be meant officials like the chien-yü-shih "superintendent", who under the Ch'in dynasty seems to have had controlling power over the governor of a chün. Cf. Chavannes, Mém. Hist., II, pp. 531-2.

(957) i.e. the other officials.

(958) Cf. par. 18, p. 288.

(959) Cf. par. 18, p. 291.

(960) [] [] seem to have been officials of the imperial stables. The two characters also occur in the Chou-li, ch. 15, p. 6b, and in the Shih-ching, I, 2 (14), Legge's ed., p. 36, where they have often been explained as the name of a wild animal.

(961) i.e. the interests of the horses and of these officials are different, so that the horses, could they but speak, would denounce their faults. 
(962) The idea is that, if people are to be promoted on account of the reputations they have, there would be much room for the arbitrary acts of bad officials.

(963) A figure of speech, meaning the ruler.

(964) Cf. Kuan-tzu, ch. 21, par. 67, p. 420 :

«If the ruler relaxes the law, in order to promote capable men because of their reputation, then ministers will become estranged from their ruler and will form cabals with their inferiors; if officials are chosen for their party connections, then people will be concerned about clever tricks and will not strive to be of use.

(965) i.e. subdue his enemies by any other means than fighting.

(966) [][] , "actions which do not become a subject". In this last case fighting is also necessary and virtue alone is powerless.

(967) i.e. punishment.

(968) In this par. a distinction is made between law officers and the executive officials; the former are called "law officers" and "officers who preside over the law" ; the latter are merely referred to as "government officials".

(969) [] "names", i.e. th e headings or items of the law.

(970) [][] seems here to mean the civil officials.

(971) As the time divisions of hours were not used before the Han dynasty, this phrase might help in dating the par. The possibility should, however, be admitted, that general indications like "the crowing of the cock", etc., are meant. Cf. note 974.

(972) Lit. "forbidden room".

(973) The Yü-shih-ta-fu under the Ch'in dynasty was in charge of all the plans and official documents. He was the third in rank.

The Ch'eng-hsiang was the Grand Councillor, the highest office.

(974) This and the use of the expression "the feudal lords" in the next phrase poi nt to the beginning of the Ch'in dynasty for the composition of this paragraph.

(975) This phrase does not seem to belong to this context.

(976) Escarra and Germain, op. cit., p. 54, mistranslate :

«Ainsi tout ce qui naît de la loi est su clairement et facilement, et est sûrenent appliqué.

(977) i.e. the rights with regard to the property are clear. In the following sentence there is a play on the word [], which can also mean "th e headings" or "items" in the law. Later I also render it by "rights and duties".

(978) Cf. Lü-shih-ch'un-ch’iu, ch. 17, p. 20 :

«Shen-tzu said : "Now, if there runs a hare, that a hundred men chase it, is not because one hare would be sufficient for a hundred men to have a share in, but because of the uncertainty of the proprietary rights. If these are uncertain, even a Yao will exert himself to the utmost — how much more then ordinary people ! And the fact that, if hares are assembled wholesale on the market, even passers-by do not look at them, is not because they do not desire hares, but because the proprietary rights over them are definite. If rights and duties are definite, then even vulgar people will not quarrel about things. Therefore the secret of governing the empire and the state consists in making rights and duties definite.

Cf. for a somewhat different version Yin Wen-tzu, ch. 1, p. 4a.

(979) i.e. his dynasty. 
(980) [] "hame" is here used in its wide sense of "terminology", i.e. the definition of all ethical, social and legal values, rights, duties and punishments.

(981) [] "master" ; used before with reference to the books of the ancients.

(982) Han Fei-tzu, ch. 19, par. 49 :

«What is called wisdom are subtle and mysterious words; subtle and mysterious words are difficult to understand, even for men of superior wisdom.

(983) Lit. "plumb line and ink", i.e. rules or directions.

(984) [][] ; this is the great slogan of the Ming-chia, the "School of Terminologists".

$$
* * *
$$


Nom du document : duyvlord_pdf.doc

Dossier :

C:ICSS $\backslash$ ChineWord051204

Modèle :

C:IWINDOWS $\backslash$ Application

DatalMicrosoft $\backslash$ Modèles $\backslash$ Normal.dot

Titre :

The book of Lord Shang

Sujet : série Chine

Auteur :

J.J.L. Duyvendak

Mots clés :

Chine ancienne, Chine antique, Chine classique, Lord

Shang, Royaumes combattants, école du légisme, légistes, fa-kia, school of law

Commentaires : http://www.uqac.ca/Classiques_des_sciences_sociales/

Date de création : $\quad$ 07/09/05 17:38

$\mathrm{N}^{\circ}$ de révision : $\quad 11$

Dernier enregistr. le : 07/09/05 21:28

Dernier enregistrement par : Pierre Palpant

Temps total d' édition81 Minutes

Dernière impression sur : $\quad$ 07/09/05 21:29

Tel qu' à la dernière impression

Nombre de pages : $\quad 211$

Nombre de mots : 86462 (approx.)

Nombre de caractères : 492834 (approx.) 